\title{
Precambrian Geology of the United States; An Explanatory Text to Accompany the Geologic Map of the United States
}

By PHILIP B. KING

GE OLOGICAL S URVEY PROFESSIONAL PAPER 902

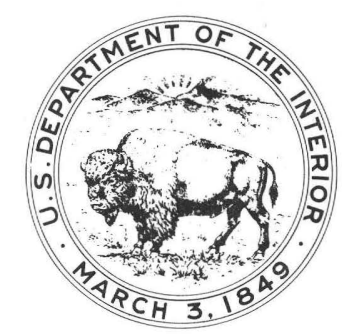

UNITED STATES GOVERNMENT PRINTING OFFICE， WASHINGTON ： 1976 


\section{UNITED STATES DEPARTMENT OF THE INTERIOR}

THOMAS S. KLEPPE, Secretary

\section{GEOLOGICAL SURVEY}

V. E. McKelvey, Director

Library of Congress Cataloging in Publication Data

King, Philip Burke, 1903-

Precambrian geology of the United States.

(Geological Survey Professional Paper 902)

Includes bibliographical references.

Supt. of Docs. No.: I 19.16:902

1. Geology. Stratigraphic-Pre-Cambrian. 2. Geology-United States. I. United States. Geological Survey. Geologic map of the United States. II. Title. III. Series: United States. Geological Survey. Professional Paper 902. QE653.K55 75-619035

For sale by the Superintendent of Documents, U.S. Government Printing Office Washington, D.C. 20402

Stock Number 024-001-02839-5 


\section{CONTENTS}

Abstract

Distribution

Data for correlation

Paleontological data

Radiometric data

Geologic applications of radiometric dating

Classification of Precambrian rocks

Classification in Minnesota

Classification in Canada

Discussion of Canadian classification

Classification on Geologic Map of United States of 1932

Later usage of U.S. Geological Survey

Interim classification of 1972

Representation of Precambrian on Geologic Map of the United States

Lake Superior Region

Precambrian W _._. 22

Precambrian X _._._._._._._. 24

Precambrian of northern Wisconsin _._._._- 26

Keweenawan Supergroup of Precambrian Y _._._._. 27

Precambrian Y rocks older than Keweenawan _...-_ 28

Precambrian Z _._._. 28

Adirondack area _______-_._- 29

Northern Appalachian region _._._._. 29

Precambrian Y of western part _______ 29

Precambrian $\mathrm{Z}$ of eastern part _._._. 31

The Avalonian belt

Central and Southern Appalachian region _..._._._. 33

Blue Ridge belt ........ 33

Precambrian Y _._. 34

Precambrian Z _._._-_ 34

Precambrian of Piedmont province _.________ 39

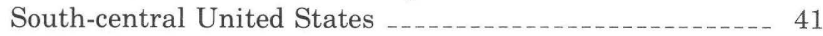

Ozark area

Arbuckle and Wichita Mountains _-_-_-_-_- 41

Llano uplift _._._. 42

Regional problems
1

Exp

Exposed Precambrian rocks of the United States-Continued Cordilleran Region _._._. 44

Central Rocky Mountains _._._._._._._._._._._._._. 45

Precambrian W

Precambrian complex of southwestern Montana _.___- 46

Precambrian X _._. 48

Precambrian Y _________._. 50

Northern Rocky Mountains _._._._._._._._._._._._._. 51

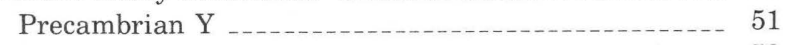

Precambrian of central Idaho _._._._._._._. 52

Precambrian Z _... 53

Southern Rocky Mountains _______._. 54

Precambrian X gneiss complex

Precambrian X and Y granitic rocks _.________._. 56

Precambrian of Needle Mountains _._._. 56

Eastern Great Basin _._._. 56

Crystalline basement (Precambrian X) _._._._._. 58

Big Cottonwood Formation (Precambrian Y) _._._._ 59

Mineral Fork Tillite and Mutual Formation (Precam-

brian Z) _... 59

Uinta Mountain Group (Precambrian Y)_____ 59

Supracrustal rocks of the allochthon (Precambrian Z) _- 61

Supracrustal rocks of Utah-Nevada border _._._._._. 62

Southern Basin and Range province _._. 62

Crystalline basement of Arizona (mainly Precambrian $\mathrm{X})$

Crystalline basement of southern California (mainly

Precambrian X) _._._._._._._. 64

Supracrustal rocks in Arizona (mainly Precambrian Y) 66

Pahrump Group of eastern California (Precambrian Y

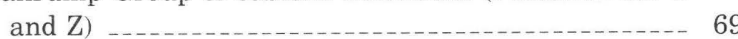

Precambrian of western Texas (mainly Precambrian Y)

Precambrian Z supracrustal rocks of western Basin and 69

Range province _..._. 72

Discussion and synthesis 74

Acknowledgments

References cited 79

\section{ILLUSTRATIONS}

Figures 1-5. Maps of the United States, showing surface distribution of Precambrian rocks as represented on the Geologic Map of the

United States:

1. Map units W, X, Y, and Z, and metamorphic complexes of probable Precambrian age

2. Rocks of Precambrian $W$.

3. Rocks of Precambrian X

4. Rocks of Precambrian Y

5. Rocks of Precambrian Z

6. Geologic map of part of the Lake Superior Region

7. Stratigraphic chart showing Precambrian units northwest and southwest of Lake Superior in Minnesota, Michigan, and

Wisconsin . 
9. Map of south-central Vermont, showing part of the Green Mountain uplift and the Athens and Chester domes

10. Map of northern part of Blue Ridge uplift in Virginia, Maryland, and Pennsylvania, showing Precambrian $\mathrm{Z}$ rocks, Precambrian Y basement, and adjacent Phanerozoic rocks _

11. Stratigraphic diagram across Blue Ridge uplift in northern Virginia, showing Precambrian $Z$ and Cambrian 12-17. Maps of:

12. Part of Blue Ridge uplift in the border region of Virginia, North Carolina, and Tennessee, showing Precambrian and Paleozoic units

13. Southwestern end of Blue Ridge belt in southern North Carolina and Tennessee, and northern Georgia, showing Ocoee Supergroup, related units of Precambrian Z, and Precambrian Y basement

14. Llano uplift, central Texas, showing Precambrian and surrounding Phanerozoic rocks --_-_-_-_- 43

15. Part of south-central United States, showing subsurface extent of late Precambrian and Early Cambrian supracrustal felsic volcanic rocks

16. Central Rocky Mountains in Wyoming, South Dakota, and Montana, showing outcrops of Precambrian rocks

17. Part of western United States and southern Canada, showing Precambrian W rocks from the Lake Superior Region to the Central Rocky Mountains

18. Map showing Precambrian rocks in the Black Hills, western South Dakota

19. Map of northern Medicine Bow Mountains, Wyoming, showing rocks of Precambrian W and X and surrounding Phanerozoic rocks

20. Map of Southern Rocky Mountains in Colorado and New Mexico, showing Precambrian rocks, the late Paleozoic geanticlines, and the Colorado Mineral Belt

21. Map showing Precambrian $\mathrm{X}$ and $\mathrm{Y}$ units in Needle Mountains, southwestern Colorado------

22. Synoptic diagram showing relations of units of Precambrian X and $\mathrm{Y}$ in Needle Mountains and their implications in the Precambrian history of the area

23. Geologic map of northeastern Utah, showing Precambrian X, Y, and Z rocks in eastern Great Basin, and the adjoining mountains and plateaus to the east

24. Map of central Arizona showing relations of Yavapai Series and other Precambrian X rocks

25. Section showing Vishnu Schist and Unkar Group (Precambrian X and Y) in the Shinumo area, Grand Canyon, northern Arizona, and the truncation of their block-faulted structure by Cambrian deposits; section of Butte fault in eastern Grand Canyon; idealized section showing disruption and distention of Apache Group and Troy Quartzite by sills and dikes of intrusive diabase

26. Map of Van Horn area, west Texas, showing Precambrian rocks and their relations to surrounding Phanerozoic rocks

27. Synoptic section across Precambrian rocks of Van Horn area, west Texas, showing structural relations of the different units and their implications in the Precambrian history of the area

28. Stratigraphic diagram showing relations between late Precambrian (Z) and lower Cambrian units exposed in different areas of the western Basin and Range province

29. Maps of the United States and parts of Canada and Mexico, showing evolution of the North American continent during Precambrian time

30. Map of western United States, showing western known extent of Precambrian rocks

\section{TABLES}

1. Sequence and classification of Precambrian rocks of Minnesota, 1951-70

2. Ages of orogenic events in Canadian Shield, as determined by different radiometric methods

3. Comparison of recent classifications proposed for the Precambrian of North America

4. Precambrian supracrustal rocks of Arizona

5. Precambrian rocks of western Texas

6. Precambrian Z-Lower Cambrian formations in western Basin and Range province 


\title{
PRECAMBRIAN GEOLOGY OF THE UNITED STATES; AN EXPLANATORY TEXT TO ACCOMPANY THE GEOLOGIC MAP OF THE UNITED STATES
}

\author{
By Philip B. King
}

\section{ABSTRACT}

Precambrian rocks are at the surface in about 10 percent of the area of the United States, but are more extensive beneath the Phanerozoic rocks, especially in the Central Interior Region. Exposures occur in southward-projecting parts of the Canadian Shield in the Lake Superior Region and Adirondack Mountains, and in smaller inliers farther south in the Central Interior. Precambrian rocks emerge in the higher uplifts produced by Phanerozoic deformations in the Appalachian and Cordilleran mountain belts to the east and west, but are very scantily represented close to the Pacific Coast.

Radiometric dating indicates that the Precambrian rocks vary widely in age, from as much as $3,550 \mathrm{~m}$.y. to about $600 \mathrm{~m}$.y., rocks with the latter ages being conformable or nearly so with the succeeding Cambrian. The radiometric data, assisted to a minor extent by scanty primitive fossils, make possible correlation of the rocks of different exposures, and they also permit a subdivision of Precambrian rocks and time into named subdivisions. In advance of a worldwide agreement on nomenclature the U.S. Geological Survey uses an interim subdivision into Precambrian W, X, Y, and Z, which correspond broadly with the Archean, Aphebian, Helikian, and Hadrynian of the official Canadian classification.

The radiometric data indicate peaks of abundance of ages at different levels, which express significant historical events-times of orogeny, of orogenic cycles, or of magmatism with or without orogeny. The principal events occurred 2,500-2,750, 1,600-1,850, 1,300-1,400, and 900-1,100 million years ago, and are named (following Canadian usage) the Kenoran, Hudsonian, Elsonian, and Grenvillian events, respectively. The events have been recorded at many places throughout the United States, Canada, and Mexico, and occur between or in the latter parts of the named subdivisions.

Different events characterize certain areas, thereby delimiting provinces in the Precambrian terrane. The oldest provinces are in northern Minnesota (an extension of the Superior province of Canada), and in Wyoming and southern Montana; they contain Precambrian $\mathrm{W}$ rocks that yield Kenoran and earlier dates. Younger provinces are to the south. Precambrian X rocks with Hudsonian dates are extensive in the Southern province of the Lake Superior Region, and also through much of the southern part of the Cordilleran region. A poorly defined province with Elsonian dates is indicated by subsurface data in the southern part of the Central Interior Region, and plutons with Elsonian ages are widely distributed in the Precambrian X rocks of the southern Cordillera. Crystalline rocks of Precambrian Y with Grenvillian dates form a wide belt in the southeastern United States, especially in the Appalachian region.

By the time of Precambrian Y, however, a large part of the remainder of the North American continent, in the United States and elsewhere, had been stabilized into a craton, and received supracrustal sediments and volcanics that were only moderately deformed, or remained undeformed during Precambrian time, producing units such as the continental Keweenawan Supergroup of the Lake Superior Region, the marine Belt Supergroup of the northern Cordillera, and the Grand Canyon Supergroup and others farther south.

During latest Precambrian time, or Precambrian Z, accumulation of supracrustal sediments and volcanics occurred mainly along the eastern and western sides of the continent, in the Appalachian and Cordilleran regions-in the east on a crystalline basement produced by the Grenvillian event, in the west lying with moderate discordance on Precambrian Y supracrustal rocks. However, in the coastward part of the Appalachian region is the Avalonian belt of Precambrian Z rocks, an exotic element which seems to have been joined to the North American continent by plate movements during Paleozoic time. It includes supracrustal rocks in the Carolina Slate Belt of the southern Appalachians, as well as farther northeast in Canada, but in southeastern New England it is represented by extensive granitic plutons that are unconformable beneath the Lower Cambrian, with radiometric dates of 570 m.y.

In most of the United States the Precambrian is separated from the Cambrian by a marked unconformity and riatus; Middle or Upper Cambrian rocks overlie Precambrian Y or older rocks. However, in the mountain belts to the east and west, supracrustal rocks of both Precambrian $\mathrm{Z}$ and Lower Cambrian were deposited, and the boundary between the Precambrian and the Phanerozoic is less obvious. The problem is most acute in the southwestern part of the Basin and Range province where Precambrian and Cambrian are parts of a thick conformable sequence of fine-grained sediments, so that there is no clear physical or faunal boundary between them.

In this account, following a statement of general principles, the Precambrian rocks of the different areas of exposure are reviewed, described, and correlated in turn. The units selected for description are in terms of modern morphology, which correspond only broadly with the provinces of Precambrian time-the Lake Superior Region, the Adirondack Mountains, the Northern and Southern Appalachian regions, the south-central United States in the Interior Lowlands, the Central Rocky Mountains, the Northern Rocky Mountains, the Southern Rocky Mountains, the eastern Great Basin, and the southern Basin and Range province. In general it is assumed that the descriptions can be understood by reference to the Geologic Map of the United States, but to clarify certain subjects, maps on larger scales or maps which illustrate special features are included. A final discussion and synthesis deals with the larger Precambrian problems, some still obscure, including the origin and evolution of the continent during Precambrian time, and the possible participation of the continent in plate tectonics.

\section{DISTRIBUTION}

Precambrian rocks underlie all the Central Interior Region of the United States and large parts of the mountain belts east and west of it. However, they are covered 
extensively by Phanerozoic rocks and form the surface of only about 10 percent of the country. By contrast, in Canada to the north Precambrian rocks form the surface of nearly half the country, mainly in the Canadian Shield.

The largest exposures of the Precambrian in the United States are in southern extensions of the Canadian Shield_in the Lake Superior Region of Minnesota, Michigan, and Wisconsin, and in the Adirondack Mountains of northern New York State (fig. 1). Older maps (such as the Geologic Map of the United States of 1932) imply that an even larger area of Precambrian occurs in the Appalachian Region to the east and southeast; large parts of this supposed Precambrian are now known to be of Paleozoic age, although authentic Precambrian does emerge in the higher uplifts through much of the length of the chain. In the Central Interior, Precambrian is exposed only in small, widely spaced areas on the crests of a few uplifts; additional knowledge of the Precambrian of this region is afforded by subsurface data. In the Cordilleran Region, a large area of Precambrian (mostly the supracrustal Belt Supergroup) extends across the Northern Rocky Mountains of western Montana and northern Idaho. Farther south in the Rocky Mountains the outcrops of Precambrian are smaller, but many of them (as in Colorado) are closely spaced. Similar small but closely spaced areas of Precambrian occur in the southern part of the Basin and Range province in Arizona and adjacent States. No Precambrian is known within 200 miles $(320 \mathrm{~km})$ or more of the Pacific Coast, except in the Transverse Ranges of southern California.

\section{DATA FOR CORRELATION}

Prime requisites for representation of any group of rocks on a regional or national geologic map are adequate classification and correlation, but these are difficult to achieve in the Precambrian.

Many parts of the Precambrian have been strongly deformed, metamorphosed, and injected with plutonic rocks; moreover, even where their primary sedimentary structures are well preserved, their fossil remains are sparse and enigmatic. While it is true that their structural complexity is perhays no greater than that of many Phanerozoic terranes whose sequences and ages have been deciphered, the few fossils in Precambrian rocks are not of the diagnostic value of those used for stratigraphic purposes in younger rocks.

In the absence of normal criteria for classification and correlation, various indirect methods were formerly used in deciphering the Precambrian record. The earth was assumed to evolve during the Precambrian, from a molten, disordered condition ("Azoic" or "Archean" time) to a better ordered condition when more familiar sedimentary and volcanic processes prevailed ("Proterozoic" or "Algonkian" time). Assumptions were made as to the nature of Precambrian orogenic processessupposedly universal cycles of deformation, plutonic injection, and peneplanation, applicable throughout a shield, or to even larger regions. Where sequences of Precambrian rocks could be worked out by conventional laws of superposition, they were compared and correlated with other sequences, even far distant, using as starting points supposed type areas, such as the Lake Superior Region. ${ }^{1}$ These early efforts failed to take into account various geological factors that are better understood now, such as the actual great length of Precambrian time-at least five times longer than Phanerozoic time. They are merely of historical interest today.

Great progress in understanding the Precambrian has been made in recent decades. Radiometric dating has made it possible to bring together many hitherto unrelated items of the larger history, and even to make a beginning in stratigraphic correlation. With this assistance, more can now be deduced as to the geochemical evolution of the earth, leading to inferences on worldwide events, such as a time of iron formation, the times of beginning of carbonate and of evaporite sedimentation, and times of glaciation. However, with the possible exception of the latter, these have only very general application to stratigraphic work. More to the point, radiometric dating has assisted in understanding the fossil record, such as it is, and to suggest at least rudimentary zonation. Moreover, much wider areas of Precambrian rocks have been geologically mapped which, coupled with radiometric dating, has assisted in understanding regional Precambrian history that is no longer restricted to a few classical and supposedly typical areas.

\section{PALEONTOLOGICAL DATA}

The fossil record is influenced by the evolution of life on the earth, but during Precambrian time evolution was probably very slow at first, and did not accelerate until much later. Classification of Precambrian fossils is difficult because even major groups of organisms must have become extinct during the long timespans involved; even in the succeeding Early Cambrian there are shelly invertebrate groups that are not assignable to any existing phyla (Glaessner, 1968, p. 586).

\footnotetext{
1The strongest statements of these propositions were in the textbooks of the time, whose authors were eager to generalize the results of the field geologists; statements by the field geologists themselves (with the exception of Lawson, 1914) were more qualified. A judicious appraisal of the status of Precambrian problems is contained in C. K. Leith's presidential address to the Geological Society of America in 1933 (Leith, 1934), and his strictures have been well justified by later developments.
} 
During the first three-quarters of Precambrian time the only remains or traces of life are those of primitive bacteria and plants. The most prominent of these remains are the stromatolites, which are biogenic sedimentary structures probably produced by algae; they include stratiform, nodular, and columnar carbonate structures. All are notoriously variable in form and no doubt were much influenced by local environmental conditions. Nevertheless, when specimens of the more distinctive columnar forms have been studied through sequences long enough, and over areas wide enough, they seem to have changed sufficiently with time to permit division into zones dated radiometrically between 1,600 and 1,350 m.y., 1,350 and 1,000 m.y., and 700 and $500 \mathrm{~m} . y$. These express very slow evolutionary changes-two orders of magnitude slower than in Phanerozoic biostratigraphic zones (Glaessner, 1968, p. 587). Stromatolite zonation has been most successfully applied in the Soviet Union (Raaben, 1969; Cloud and Semikhatov, 1969) where Precambrian stromatolite-bearing rocks can be studied across the whole expanse of northern Eurasia, but similar studies are in progress in Precambrian areas elsewhere.

The earliest authentic metazoan fossils occur in strata not far beneath the Cambrian with ages of 600 to 700 m.y. - especially in the Ediacaran of South Australia, the Vendian of northern Eurasia, and a scattering of other formations and localities in the Eastern Hemisphere (Glaessner, 1971). The only reported occurrences in North America are in southeastern Newfoundland (Conception Group) (Misra, 1971, p. 979-980), in North Carolina, and in eastern California (Deep Spring Formation) (Cloud and Nelson, 1966). Some or most of the forms occur at all localities, indicating a wellcharacterized fauna-various primitive coelenterates, and forms with less certain affinities that probably belong to extinct phyla (Glaessner, 1961, p. 73-77; Sokolov, 1973, p. 209-215). They were soft-bodied animals, whose imprints are preserved on bedding surfaces at unusually favorable situations. Although the strata in which they occur are clearly older than the Cambrian, there is some philosophical justification for considering them a basal unit of the Paleozoic, younger than the Precambrian as formally defined (Cloud, 1968, p. 36-37). Hard-shelled fossils, such as archeocyathids and trilobites, only appear in the Cambrian itself, for reasons that are still debated (Cloud, 1968, p. 42-49).

\section{RADIOMETRIC DATA}

Dating by radiometric methods has advanced far beyond the first few determinations on uranium and thorium ore minerals nearly three-quarters of a century ago. Aside from suggesting the possibilities of the method and the great length of geologic time, these first determinations were of little geologic use because of the rarity of the minerals, and because most kinds of rocks do not contain them, hence were as yet undatable. Subsequently, and especially during the last few decades, many other methods have been devised, some of them applicable to ordinary rocks. At the same time, however, the hazards and pitfalls of the radiometric methods of dating have become more apparent.

The lead-alpha method of dating zircon gives generalized results and is useful as a reconnaissance tool, but has little value for detailed work.

The potassium-argon method uses potassium-bearing minerals such as biotite, muscovite, and hornblende, hence has wide application to common igneous and metamorphic rocks. It is therefore useful for sampling and appraisal of wide areas of Precambrian rocks (as in the Canadian Shield). The results are mostly consistent among themselves, and thus indicate the relative ages of different units and provinces. However, the ages obtained in the Precambrian are rather consistently less than those by the other methods mentioned below, owing to gradual loss of argon from the mineral lattices. Because of differences in their molecular structure, this loss is greatest in biotite, less in muscovite, and least in hornblende.

Also, argon is lost during the cooling that succeeds time of igneous injection or of metamorphism, and it does not become fixed in the mineral until the temperature descends to a lower level. Thus many dates are "cooling dates" that are younger than the actual times of injection and metamorphism. These differences are least in low-grade metamorphic rocks and greatest in high-grade rocks of granulite facies that underwent the deepest burial and the greatest subsequent uplift and erosion.

The rubidium-strontium method is not subject to the loss of a gas daughter product as in the potassium-argon method, and hence yields more reliable dates, but it has several of its own problems. Both elements are subject to gain or loss during metamorphism, and there is disagreement as to the $\mathrm{Rb}^{87}$ half-life decay constant. Depending on the constant adopted, the dates obtained on Precambrian rocks by the rubidium-strontium method may differ by 6 percent, or 150 m.y. at 2,500 m.y. ago.

The most nearly absolute figures for primary crystallization are those obtained from uranium-lead and lead-lead methods, but the elements to be analysed are rare. The methods were originally applied to uranium and thorium ore minerals which did not have wide geological application; but uranium and lead also occur in minute amounts in the common accessory minerals zircon, monazite, apatite, and sphene, for which analytical procedures are very exacting. Although fewer dates 


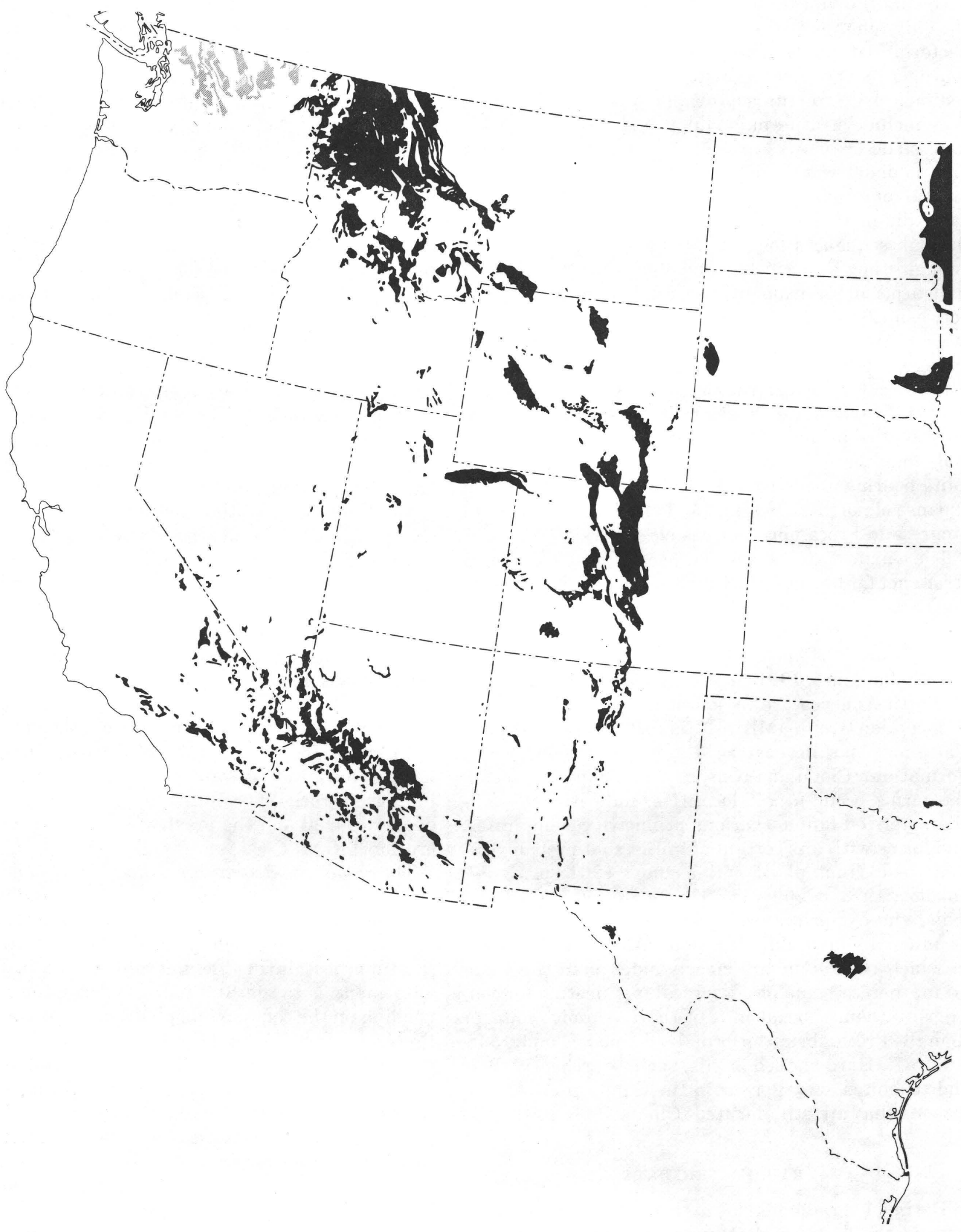

FIgURE 1.-Map of the United States showing surface distribution of Precambrian rocks as represented on the Geologic Map of the United States (map units W, X, Y, and Z). Also shown are metamorphic complexes (map units ms and $\mathrm{m}_{1}-\mathrm{m}_{4}$ ), which probably include rocks of Precambrian age. 


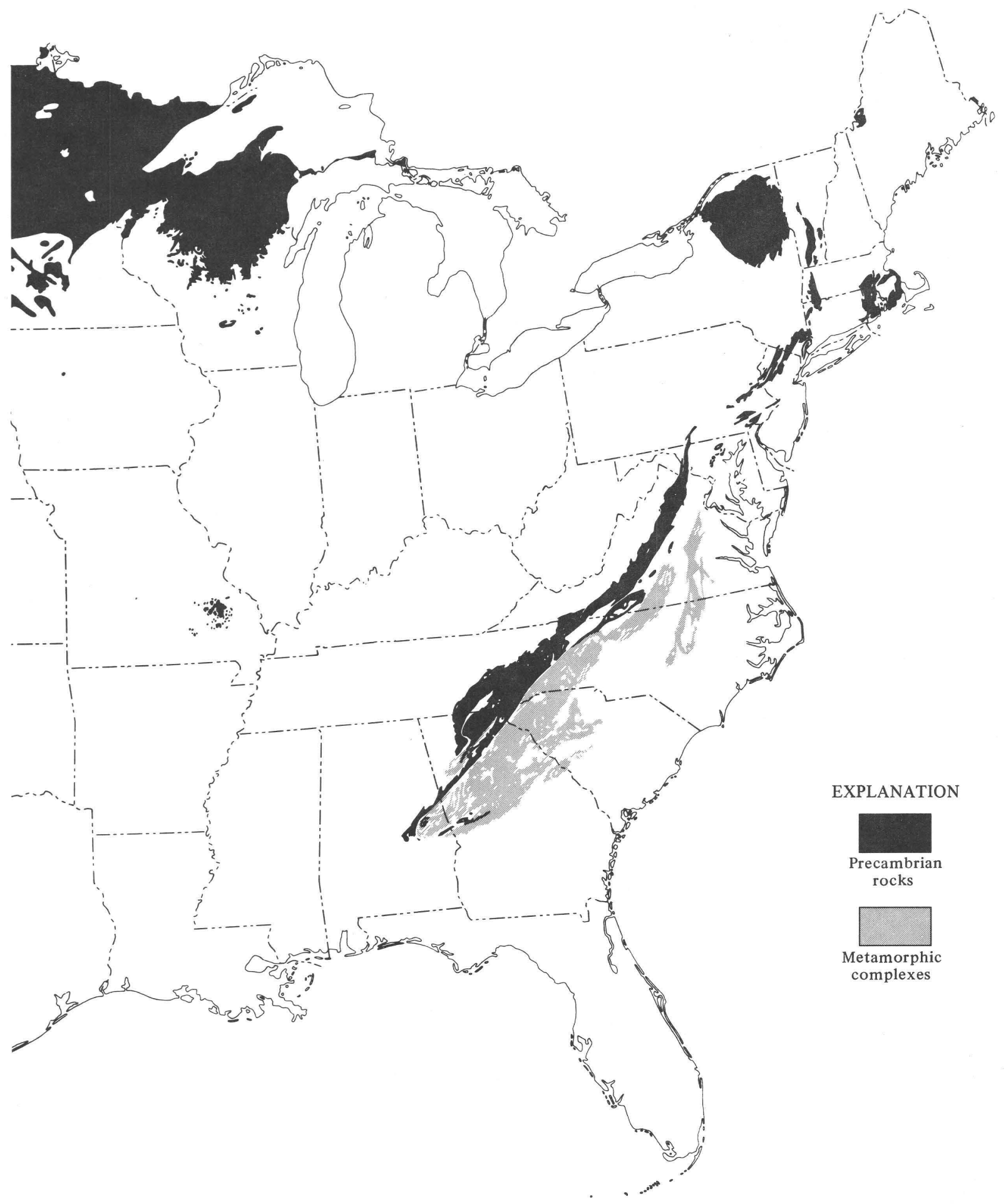

Figure 1.-Continued. 
can be obtained by uranium-lead and lead-lead methods, they are useful as controls for the less exact results obtained by the other methods.

\section{GEOLOGICAL APPLICATIONS OF RADIOMETRIC DATING}

These various methods indicate the times of crystallization during igneous intrusion, and of metamorphism-aside from the cooling factor. Dating of Precambrian supracrustal rocks of sedimentary and volcanic origin is more difficult.

Direct dating from primary minerals in the Precambrian supracrustal rocks in the Canadian Shield is largely unsuccessful, and the dates obtained commonly express merely the age of the metamorphism (Stockwell, 1968, p. 692). Elsewhere, it has been possible in a few places. Glauconite and argillite in the little deformed or metamorphosed Belt Supergroup of the Northern Rocky Mountains are susceptible of dating by potassium-argon and rubidium-strontium methods; also, potassium-argon determinations have been made on hornblende from the Purcell Lava and associated sills interbedded in the Belt sediments (Obradovich and Peterman, 1968, p. 739-740). Zircons from the late Precambrian felsic lavas of low metamorphic grade in the Blue Ridge of the Central Appalachians have been successfully dated by the uranium-lead method (Rankin and others, 1969).

For dating the Precambrian supracrustal rocks of the Canadian Shield and other complex areas, recourse must generally be had to indirect methods, which bracket the times of accumulation between maximum and minimum limits. The maximum age of a sequence is indicated by the age of the plutonic and metamorphic rocks of its basement; the minimum age is indicated by the age of its metamorphism, or by the age of the igneous rocks that intrude it.

\section{CLASSIFICATION OF THE PRECAMBRIAN ROCKS}

With the new data available, proposals are being made in many parts of the world for reclassification of the Precambrian rocks. The subject is under consideration by the Subcommission on Precambrian of the International Commission on Stratigraphy, Kalervo Rankama, chairman. The subcommission is working toward an agreement on Precambrian classification and nomenclature that will meet worldwide acceptance, but such an agreement is still a matter for the future. The worldwide implications do not concern us here; our interest is in the interim problems of classification of the Precambrian in North America, and specifically in the United States.

\section{GLASSIFICATION IN MINNESOTA}

One of the first efforts to make effective use of radiometric data to classify the Precambrian was in Minnesota (Goldich and others, 1961) that refined and revised an earlier classification based largely on conventional geologic criteria (Grout and others, 1951). The State of Minnesota includes nearly half of the area of Precambrian rocks of the Lake Superior Region in the United States. Moreover, its sequence of Precambrian rocks is much like that across Lake Superior in northern Michigan and Wisconsin, so that any classification arrived at in Minnesota has applications over a wider area.

Table 1 summarizes the various classifications proposed for Minnesota, including that of 1961. From the table, it is apparent that basic concepts of the Minnesota sequence have changed little through the years, but that significant changes have been made in classification and terminology. A notable change in 1961 was the transfer of the Animikie Group from Late Precambrian to Middle Precambrian and the Knife Lake Group from Middle Precambrian to Early Precambrian, as a result of dating the Penokean orogeny at 1,700 m.y. and the Algoman orogeny at 2,500 m.y. (the column for 1968 indicates that these dates are actually greater). These extreme ages were incompatible with the relative youth previously assumed for the two groups. The so-called "Laurentian orogeny," previously considered to divide the Early and Middle Precambrian, was now downgraded to a minor role in the Early Precambrian.

Emendations after 1961 include renaming the socalled "Grenville orogeny" of Minnesota the "Keweenawan igneous activity"; even though the event is broadly correlative with the true Grenvillian orogeny farther east, it was essentially anorogenic in Minnesota. Also, in the classification of 1970 and 1972, the absolute distinctions between the Knife Lake and Keewatin Groups are discarded, as the sediments of the one and the volcanics of the other have variable mutual relations. With this, the so-called "Laurentian orogeny" and its accompanying epoch of granite intrusion disappears; granites within the Lower Precambrian are now interpreted as local phenomena. Nevertheless, as shown in 1968, extremely ancient rocks occur in southwestern Minnesota, dated at 3,550 m.y.

Radiometric dating indicates major events in Minnesota at 2,700-2,750 m.y., 1,850 m.y., and 1,100 m.y., designated the Algoman orogeny, Penokean orogeny, and Keweenawan igneous activity (= Grenville orogeny). We will find these events again in the Canadian Shield in Canada, and elsewhere, and will interpret them as important markers for classifying the Precambrian of North America. 
TABLE 1.-Sequence and classification of Precambrian rocks of Minnesota, 1951-70.

\begin{tabular}{|c|c|c|c|}
\hline Grout and others (1951) & Goldich and others (1961) & Goldich (1968) & $\begin{array}{l}\text { Sims (1970): } \\
\text { Sims and Morey (1972) }\end{array}$ \\
\hline Cambrian & Cambrian & Cambrian & Cambrian \\
\hline $\begin{array}{l}\text { Unconformity } \\
\text { Later Precambrian } \\
\text { Keweenawan Group } \\
\text { Medial volcanics intruded } \\
\text { by Duluth Gabbro }\end{array}$ & $\begin{array}{l}600 \text { m.y. } \\
\text { Late Precambrian } \\
\text { Keewanawan System } \\
\text { Medial volcanics intruded by } \\
\text { Duluth Complex (Grenville } \\
\text { orogeny, } 1,100 \text { m.y.) }\end{array}$ & $\begin{array}{l}600 \text { m.y. } \\
\text { Late Precambrian } \\
\text { Sediments and medial North } \\
\text { Shore Volcanic Group, in- } \\
\text { truded by Duluth Complex } \\
\text { (Keeweenawan igneous activ- } \\
\text { ity, } 1,000-1,200 \text { m.y.) }\end{array}$ & $\begin{array}{l}\text { Upper Precambrian } \\
\text { Keweenawan Series } \\
\text { Medial volcanics intruded by } \\
\text { Duluth Complex }\end{array}$ \\
\hline Animikie Group & $\begin{array}{l}\text { Penokean orogeny, } \\
1,700 \text { m.y. } \\
\text { Middle Precambrian } \\
\text { Granitic intrusives } \\
\text { Huronian System } \\
\text { Animikie Group }\end{array}$ & $\begin{array}{l}\text { Penokean orogeny, } \\
1,600-1,900 \text { m.y.) } \\
\text { Middle Precambrian } \\
\text { Granitic intrusives } \\
\text { Animikie Group }\end{array}$ & $\begin{array}{l}\text { Penokean orogeny } \\
\text { Middle Precambrian } \\
\text { Granitic intrusives } \\
\text { Animikie Group }\end{array}$ \\
\hline $\begin{array}{l}\text { Unconformity } \\
\text { Medial Precambrian } \\
\text { Algoman intrusives } \\
\text { Knife Lake Group }\end{array}$ & \multirow{3}{*}{$\begin{array}{l}\text { Algoman orogeny, } \\
2,500 \text { m.y. } \\
\text { Early Precambrian } \\
\text { Granitic intrusives } \\
\text { Temiskamian System } \\
\text { Knife Lake Group } \\
\text { Laurentian orogeny, age? } \\
\text { Granitic intrusives } \\
\text { Ontarian System } \\
\text { Keewatin Group } \\
\text { Coutchiching? } \\
\text { Older rocks }\end{array}$} & \multirow{3}{*}{$\begin{array}{l}\text { Algoman orogeny, } \\
\text { 2,400-2,750 m.y. } \\
\text { Early Precambrian } \\
\text { Granitic intrusives } \\
\text { Knife Lake Group } \\
\text { Laurentian orogeny, age? } \\
\text { Granitic intrusives } \\
\text { Keewatin Group } \\
\text { Coutchiching? } \\
\text { Older rocks, } \\
\text { 3,300-3,550 m.y. }\end{array}$} & $\begin{array}{l}\text { Algoman orogeny } \\
\text { Lower Precambrian } \\
\text { Granitic intrusives } \\
\text { Metasedimentary and metavol- } \\
\text { canic rocks, with various mu- } \\
\text { tual relations }\end{array}$ \\
\hline $\begin{array}{l}\text { Unconformity } \\
\text { Earlier Precambrian } \\
\text { Pre-Knife Lake } \\
\quad \text { intrusives }\end{array}$ & & & $\begin{array}{l}\text { Granitic intrusives, older than } \\
\text { part of metasedimentary rocks }\end{array}$ \\
\hline Soudan Iron-Formation & & & $\begin{array}{l}\text { Gneiss and schist, southwestern } \\
\text { Minnesota }\end{array}$ \\
\hline
\end{tabular}

\section{CLASSIFICATION IN GANADA}

A more far-reaching reclassification of the Precambrian rocks on the basis of radiometric dating has been made by the Geological Survey of Canada. This deserves lengthy consideration, as it involves our neighbor to the north and its geological survey, as well as the largest exposure of Precambrian rocks in North America. The reclassification was carried out under the leadership of Clifford $\mathrm{H}$. Stockwell for use on the new Geologic and Tectonic Maps of Canada then in preparation (1969), and was based on an accelerated program of mapping the Precambrian rocks of the country and of radiometric dating, chiefly by the potassium-argon method.

Outcrops of Precambrian rocks are nearly uninterrupted in the Canadian Shield in the central and eastern part of the country, except for submerged parts such as Hudson Bay, and for the area of Phanerozoic cover in the Hudson Bay Lowland. This vast Precambrian area was once thought to be a homogeneous body, as implied on the Geologic Map of North America of 1912, hence subject from time to time to universal cycles of orogeny and peneplanation. Field studies during the last halfcentury have demonstrated, on the contrary, that it is inhomogeneous, and divisible into provinces with different rocks and histories, that developed independently during Precambrian time. Increasing knowledge has heightened the distinctions between the provinces and has sharpened their boundaries. Many of the boundaries are structural lineaments, emphasized further by geophysical anomalies; some are stratigraphic, where supracrustal rocks of a younger province overlap the basement of an adjoining older province.

Of the provinces of the Canadian Shield, only a few bear directly on Precambrian problems in the United States: the Superior province of ancient rocks which includes the Lower Precambrian of Minnesota (see above); the Southern province of somewhat younger rocks, which includes the remainder of the Lake Superior Region in the United States and Ontario; and the Grenville province farther east, which extends into the Adirondack Mountains of New York State. The Precambrian of the United States no doubt includes other extensions of the shield provinces, and additional provinces, but they are less apparent at the surface because of the interrupted outcrops.

Radiometric dating has underscored the discreteness of the provinces. Each has its own characteristic peak of 
abundance of dates, well expressed in histograms (for example, Stockwell, 1964, fig. 2). A scattering of older and younger dates also occurs, the older expressing earlier orogenic events nearly overwhelmed by the dominant events, the younger being from dike rocks and other anorogenic intrusives.

The dominant sets of dates in the different provinces are interpreted as having been produced by orogenies (Stockwell, 1961, p. 111-113). Orogeny is defined as a period of mountain building, accompanied by folding, metamorphism, and granite intrusion, each orogeny being followed by a long period of uplift, erosion, and cooling before the next set of supracrustal rocks was laid down. The scatter of dates in the rocks of each province may extend over a span of as much as 300 m.y., but this is interpreted as partly the result of analytical error; the actual duration of an orogeny is believed to be 100 m.y. or less.

In order to refine further the orogenic times, the available dates have been analyzed statistically (Stockwell, 1964, p. 4-7), using those from a single province, by a single method (for example, potassiumargon), and of orogenic origin (rather than relicts of earlier events, or of postorogenic events). The statistical analysis for each province yields a mean on the Gaussian or probability curve, and a standard deviation. The mean figure is interpreted as representing the probable climax of an orogeny, and the mean minus the standard deviation the probable end of this orogeny.

Three principal orogenies are recognized in the Canadian Shield, the Kenoran (= Algoman of Minnesota), the Hudsonian ( = Penokean of Minnesota), and the Grenvillian (= Keweenawan igneous activity of Minnesota). Each orogeny has its "type region" in one of the provinces; "it is hoped that, eventually, it may be possible to select much smaller areas for type regions, while still retaining the present geological definitions and still containing rocks and minerals that are suitable for dating by a variety of methods on a variety of minerals" (Stockwell, 1972, p. 3). The Kenoran has its type region in the Superior province, where it has a mean age of 2,490 m.y.; the Hudsonian its type region in the Churchill province, where it has a mean age of 1,935 m.y.; and the Grenvillian its type region in the Grenville province, where it has a mean age of 945 m.y. These orogenies may be poorly expressed or absent in other provinces. The Grenvillian is unique in the Grenville province, and has no orogenic counterparts elsewhere in the shield; the Hudsonian is missing in the Superior province, but it recurs in the Southern province, and in some of the far northern provinces.

Besides these, an additional Elsonian orogeny was proposed, based on a scatter of radiometric dates in the Nain province of Labrador, with a mean age of 1,370 m.y. (Stockwell, 1964, p. 2). Later work demonstrates that the events represented by these dates are not orogenic; instead, they were produced by adamellite (quartz monzonite) and anorthosite intrusions into rocks already consolidated by the Hudsonian orogeny (Taylor, 1971, p. 580-582). The Elsonian is more properly termed an "event" (King, 1969, p. 35; Stockwell, 1972, p. 3).

As indicated earlier, the potassium-argon method on which these radiometric ages are based has many advantages, but the dates obtained are consistently younger than those obtained by other methods. Subsequent to the work summarized here, the orogenic periods have been checked by a smaller number of uranium-lead and rubidium-strontium determinations, all of which indicate older, and probably truer ages (Stockwell, 1972), as shown in table 2.

Besides the major Precambrian orogenic events recognized by Stockwell in the Canadian Shield, lesser events late in the Precambrian have been described in other parts of Canada, mostly insecurely dated radiometrically and not necessarily of the same agethe East Kootenay and Racklan orogenies in the Cordilleran province (Douglas and others, 1970, p. 373) and the Avalonian orogeny in the Appalachian province (Poole and others, 1970, p. 232-233). Of these, the latter is of the greatest interest here because of its probable extension into the Eastern United States; the evidence will be treated at greater length later (p. 33, 39).

The radiometric and orogenic data just summarized have been used to redefine the sequence of Precambrian rocks in Canada. The Precambrian of Canada has traditionally been divided into Archean and Proterozoic Eons, and these and their subdivisions are now more precisely defined with the aid of the new data: Archean prior to the end of the Kenoran orogeny, Lower Proterozoic between the ends of the Kenoran and Hudsonian orogenies, Middle Proterozoic between the ends of the Hudsonian and Grenvillian orogenies, and Upper Proterozoic between the end of the Grenvillian orogeny and the beginning of the Phanerozoic. Each orogenic event is thus placed within the preceding time division, and the end of the orogeny is considered to mark the upper boundary of the subdivision.

New names are proposed for the subdivisions of the Proterozoic (Stockwell, 1964, p. 7-9): Aphebian for Lower Proterozoic, Helikian for Middle Proterozoic, and Hadrynian for Upper Proterozoic. The names are derived from Greek roots: Aphebian from "aphebos," or old maturity; Helikian from "helikia," or maturity; and Hadrynian from "hadrynes," or young maturity. Further subdivisions can then be created; for example, the Helikian is divided into Paleohelikian and Neohilikian, bounded by the Elsonian event. The new names 
TABLE 2.-Ages of orogenic events in Canadian Shield, as determined by different radiometric methods [Based on Stockwell, 1964, 1972]

\begin{tabular}{|c|c|c|c|c|}
\hline \multirow[t]{2}{*}{ Event } & \multicolumn{4}{|c|}{$\begin{array}{l}\text { End of event in millions of years (=mean minus } \\
\text { standard deviation) }\end{array}$} \\
\hline & $\mathrm{K} / \mathrm{Ar}$ & $\mathrm{U} / \mathrm{Pb}$ & $\begin{array}{c}\mathrm{Rb} / \mathrm{Sr} \\
\text { constant } 1.47\end{array}$ & $\begin{array}{c}\mathrm{Rb} / \mathrm{Sr} \\
\text { constant } 1.39\end{array}$ \\
\hline
\end{tabular}

\begin{tabular}{lrlll}
\hline $\begin{array}{l}\text { Grenvillian } \\
\text { orogeny }\end{array}$ & 880 & ca. 1,000 & ca. 1,010 & ca. 1,070 \\
$\begin{array}{l}\text { Elsonian } \\
\text { event }\end{array}$ & 1,280 & ? 1,400 & & \\
$\begin{array}{l}\text { Hudsonian } \\
\text { orogeny }\end{array}$ & 1,640 & ca. 1,800 & $? 1,750$ & $? 1,850$ \\
$\begin{array}{l}\text { Kenoran } \\
\text { orogeny }\end{array}$ & 2,390 & ca. 2,560 & ? 2,540 & ? 2,690 \\
\hline
\end{tabular}

make it possible for there to be many subdivisions within the Precambrian (or specifically within the Proterozoic), instead of the three descriptive categories of "lower," "middle," and "upper" that are available in the English language, and they avoid such unfortunate expressions as "lower upper" and "middle lower" which have sometimes been used for smaller subdivisions.

\section{DISCUSSION OF CANADIAN GLASSIFICATION}

The classification of the Precambrian set forth above has been accepted by the Geological Survey of Canada for use in its published maps and reports, but it has been criticized by other geologists (for example, Goldich, 1968, p. 722; James, 1972 a, p. $1132 ; 1972 b$, p. 2085) in the following terms:

(1) The statistical method of defining orogenies and subdivisions is questionable, as it depends on the validity of the areal unit selected for analysis, the effectiveness of the sampling, and whether the dates selected rather than discarded represent a single population.

(2) Reliance on the potassium-argon method of dating produces unreliable results for determining the ages of the units.

(3) The wide scatter of dates within each province is difficult to reconcile with the assumption that they were produced by a single orogeny, rather than by an orogenic cycle comprising many successive orogenies (King, 1969, p. 33; compare James, 1960, p. 107).

(4) Orogenies have been discredited as the fundamental basis for stratigraphic classification in the Phanerozoic, and their value for this purpose in the Precambrian should be no greater.

(5) Archean has been differently defined as to age limits from one country to another, and from one geologist to another.

(6) The new names proposed for subdivisions of the Proterozoic are unfamiliar and cumbersome, and do not clearly indicate their sequential relations.

(7) New names for major units of the Precambrian should not be proposed unilaterally, but by international agreement.

The reader can judge for himself between these adverse criticisms and the Canadian viewpoint just summarized. Here, discussion of only one item, the Archean, is desirable.

The term "Archean" has been widely used for more than a century for the oldest visible rocks of the earth, which are supposed to have special characters. "By later Precambrian time, the patterns of sedimentation, mountain building, and crustal evolution seem to have been much the same as they are now. The Archean is commonly thought to have been different-a time when the atmosphere and oceans were unlike the present, a time prior to crustal organization into cratons and geosynclines, a time unique in earth history" (Pettijohn, 1972, p. 133). Moreover, significant geochemical differences have been discerned between rocks formed during the "Archean" and the "Proterozoic," or before and after about 2,500 m.y. ago (Engel and others, 1974, p. 852).

One of the original areas in which the Archean was recognized is the Canadian Shield, and especially the Superior province, a terrane consisting of linear belts or islandlike areas of supracrustal rocks, interspersed with or surrounded by a more extensive sea of intrusive granite. The supracrustal rocks include metavolcanics that are mainly andesitic and basaltic greenstones; and metasediments which, where best preserved, are graywackes and slates with interbedded conglomerate and iron formation, and elsewhere are migmatized quartz-mica schists and paragneisses. Their extreme age is demonstrated in places by unconformable relations of both the supracrustal rocks and granites beneath the middle Precambrian rocks, and by radiometric dating. Similar terranes are recognized in the shield areas of other continents (for example, Australia and South Africa), and have likewise been called Archean.

The term Archean has also, of course, been misapplied to any thoroughly metamorphosed basement, especially before the period of radiometric dating. Thus, the metamorphic basement of the Appalachian region was commonly called "Archean," until radiometric dating demonstrated that it was not consolidated until about 1,000 m.y. ago, at the time of the Grenvillian orogeny of the Canadian Shield.

These misapplications aside, a worldwide survey of usage indicates much diversity of judgment as to the date of termination of the Archean (Rankama, 1970, p. 214, 216), with proposed dates from less than 2,000 m.y. to nearly 3,000 m.y. Proposals for a termination at less than 2,000 m.y. seem to have little merit; the main problem is regarding diverse proposals for dates between 2,000 and 3,000 m.y. Some of the latter dis- 
crepancies represent differences in field observations and analytical methods and can be adjudicated. Other discrepancies are probably genuine; perhaps "Archean" conditions ended at different (but everywhere ancient) times from one shield area to another.

The ancient features of the earth, expressed by the rocks and the conditions that these imply, seem to be unique and well characterized, whether they be called "Archean" or by some other name. The problem is how to translate these concepts into a definition of stratigraphic value. Valid definitions can be proposed in specific areas, such as the Canadian Shield, but difficulties arise when they are expanded into a definition of worldwide application. It therefore remains to be seen whether such a worldwide definition can be worked out, or whether the term Archean must be discarded.

\section{CLASSIFICATION ON GEOLOGIC MAP} OF UNITED STATES OF 1932

The Geologic Map of the United States of 1932 was compiled before the development of meaningful radiometric dating and was the last major publication of the U.S. Geological Survey which used the subdivisions "Archean" and "Algonkian" that had been standard in Survey publications for the preceding half-century. The classification used on this map is illustrated by the following abstract of its legend:

Lake Superior Region

Algonkian

Keweenawan: sedimentary, Akl; volcanic, Akv

Huronian: lower, middle, and upper, Ahl, Ahm, Ahu

Archean

Keewatin Series, $A$ Rk

Precambrian undivided

Precambrian intrusives, in

New England and the Adirondacks

Adirondacks

Algonkian?

Adirondack batholith, $\mathrm{Ab}$

Archean?

Older igneous rocks, $A \mathrm{R}$

Grenville Series, ARg

New England

Algonkian?

Younger sedimentary schists, As

Archean?

Older sedimentary and ignerius gneisses, ARgn

Appalachian Region

Algonkian? (Glenarm Series)

Wissahickon Schist:

oligoclase-biotite schist, Awh

albite-chlorite schist and garnetiferous phyllonite, Awl

schist with igneous injections, Awl'

Cockeysville Marble and Setters Formation, Acs

Granite, gabbro, and hornblende gneiss, Agn

Mylonitized granite gneiss and hornblende gneiss, Agg

Archean?

Volcanic rocks, Av

Older gneiss, AR gn
Midcontinent Region

Algonkian?

Gneiss, schist, and quartzite, Agn

Granite, porphyry, and gabbro, Agr

Great Plains

Algonkian?

Sedimentary schist and quartzite, As

Intrusive rocks, $\mathrm{Ai}$

Rocky Mountains

Algonkian

Belt Series: undivided, Ab; lower part, Abl; upper part, Abu

Archean

Archean rocks, $\mathbb{A}$

Granite, ARg

Pacific Coast Region, Great Basin, and Columbia River Plateau

Precambrian

Granite, diabase, and other intrusive rocks, $\mathrm{p} € \mathrm{~g}$

Schist, gneiss, and granite, $\mathrm{p} €$

\section{LATER USAGE OF U.S. GEOLOGICAL SURVEY}

When first proposed by the U.S. Geological Survey, the Archean and Algonkian were conceived to be periods or systems in a Proterozoic Era, which were time-stratigraphic units comparable in scope and probably in length to the Phanerozoic periods or systems. In actual practice in Survey publications, however, they were used empirically, Archean for dominant plutonic and metamorphic rocks and Algonkian for dominant supracrustal rocks.

By 1933 the results had become so incongruous that these subdivisions were abandoned, and the prePhanerozoic rocks were designated by the title Precambrian alone. Any subdivisions made were applied informally as lower and upper (early and late) or as lower, middle, and upper (early, middle, and late), and were used in a relative sense in local areas, without respect to any overall classification and correlation; the informal terms might thus vary in absolute age from one area to another. This procedure was useful in studies of particular areas, but was without value for regional work.

This classification was nevertheless followed on the U.S. Geological Survey's Geologic Map of North America of 1965, where the Precambrian was divided in many areas into lower Precambrian (p€l) and upper Precambrian $(\mathrm{p} € \mathrm{u})$, with unrealistic and sometimes misleading results.

On the U.S. Geological Survey's Tectonic Map of North America of 1969 a more detailed interim classification of the Precambrian was used, for purposes of this map only. The Precambrian was divided into Archean, Lower Proterozoic, Middle Proterozoic, and Upper Proterozoic, following Canadian usage that had prevailed up to 1963, to enable effective use to be made of Canadian tectonic data that were being contributed to the map. 
The classification was also extended to Greenland on the northeast, and to the United States and Mexico to the south on the basis of radiometric data then available.

\section{INTERIM CLASSIFICATION OF 1972}

By the time compilation of the present Geologic Map of the United States began in 1967, it was clear that major improvements could be made in the representation of the Precambrian on the Geologic Map of 1932, partly resulting from increased knowledge of the local Precambrian sequences, partly from correlation of the different sequences by radiometric dating. The experience of the Canadian geologists in the Canadian Shield indicated the general lines that a revised classification of the Precambrian of North America would assume, and the experience of compiling the Tectonic Map of North America demonstrated that such a classification could be extended to the Precambrian of the United States. Compilation of the Precambrian for the Geologic Map therefore proceeded on this basis.

In 1970 , to verify the results of the compilation, and to produce an interim classification of the Precambrian for use on the map and in other Survey publications, the U.S. Geological Survey appointed a Special Panel consisting of M. D. Crittenden, Jr., Chairman, J. E. Harrison, and J. C. Reed, Jr., to advise the Geologic Names Committee and the Chief Geologist. After Survey approval, their recommendations were published as Note 40 of the North American Stratigraphic Commission (James, 1972a).

During its deliberations, the panel reviewed the various units and their age assignments that were shown on the Geologic Map, enlisting the advice of Z. E. Peterman and C. E. Hedge, geochronologists of the U.S. Geological Survey. Various minor corrections and improvements were made in the age assignments of various units, but the four gross subdivisions shown on the Geologic Map were verified.

The panel therefore recommended an interim adoption of these subdivisions. However, rather than apply formal names to them, as in Canada, it was recommended that they be designated informally by the letters $\mathrm{W}, \mathrm{X}, \mathrm{Y}$, and Z. These letters would be especially useful for map symbols, as there was no likelihood of their being confused with any other symbol (other possible letter sequences, such as $\mathrm{A}, \mathrm{B}, \mathrm{C}$, and $\mathrm{D}$, were already preempted by map symbols for other systems). The letter $\mathrm{W}$ was used for the oldest recognized subdivision, thus providing for the possibility that still older Precambrian subdivisions might be separated later, which could be symbolized by preceding letters of the alphabet.
The boundaries between the subdivisions "were selected so as to split as few of the known episodes of sedimentation, orogeny, or plutonism as possible" (James, 1972a, p. 1129), hence were initially based on geologic features. Nevertheless, they were not intended to correspond to natural events such as orogeny or plutonism; once established, they were defined by geochronology alone.

The basis for the proposed classification thus differs from the basis for the Canadian classification, in which the boundaries are defined by natural features or events whose ages were established by radiometric means. The opposing rationales reflect the different geologic conditions in the two countries. In Canada Precambrian rocks are exposed nearly continuously over vast expanses of the Canadian Shield, so that regional geological features are an evident and obvious means of classification. In the United States outcrops are relatively small and some are so widely spaced that identification of regional geological features are necessarily much more subjective. Here, the only assured means of classifying the rocks of an outcrop is by age alone. Despite these differences, the major subdivisions of the Precambrian in Canada and the United States are much the same and are broadly correlative from one country to the other. The two classifications, and the earlier one in Minnesota, are compared in table 3.

Like all stratigraphic schemes, the interim classification of the U.S. Geological Survey creates problems when applied in detail.

New radiometric data sometimes improve the dating of rocks or events (see Stockwell, 1972). "The most significant practical difference between subdivision based on geochronology and that based on stratotypes is that revision in age of the given body of rock would result in

TABle 3.-Comparison of recent classifications proposed for the Precambrian of North America

N Numbers are ages in millions of years. In the first column, numbers combine the results of various analytical methods; in the second column first number is by K-Ar method, second by $\mathrm{U} / \mathrm{Pb}$; in the third column numbers are arbitrary]

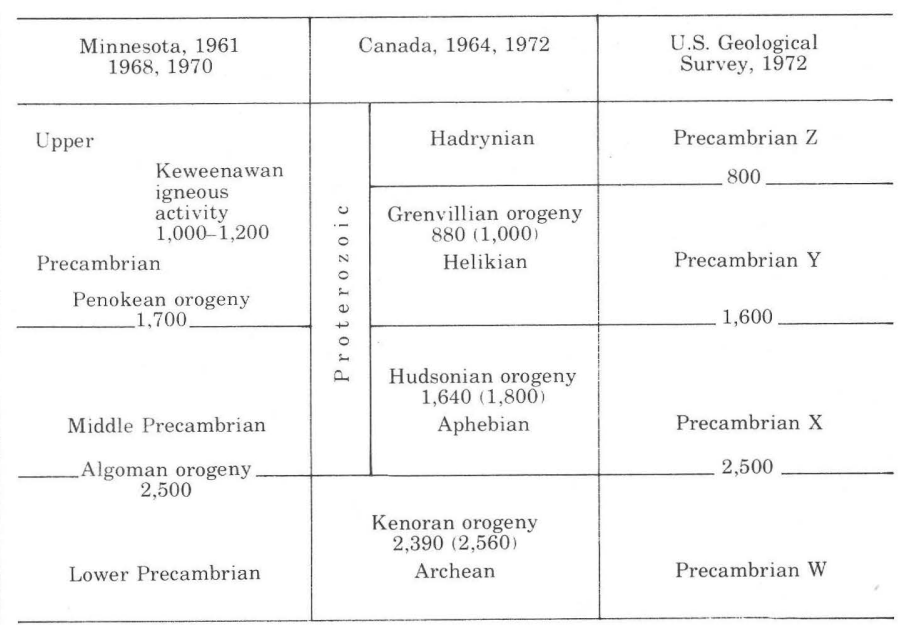


reassignment of the rock unit in the time scale, rather than readjustment of the time scale itself" (James, 1972a, p. 1131). Under the Canadian scheme the boundaries of the subdivisions are revised in age; under the United States scheme the boundaries remain fixed and the specific rock unit is moved from one subdivision to another, even though this might result in geologically unnatural groupings. In general, the boundaries between the subdivisions were carefully enough chosen by the Special Panel so that most such problems will be avoided, but some will certainly arise.

The defined age boundary between Precambrian Y and $\mathrm{Z}$ remains problematical. An 800-m.y. boundary was chosen by the panel on the assumption that it was the age of termination of deposition of the Belt Supergroup in the Northern Rocky Mountains. This date is no more than an approximation, as the termination is merely bracketed between determined dates of 930 and 760 m.y.; it is suspect because the lower part of the Precambrian Z Windermere Group that lies unconformably on the Belt to the west has been dated between 820 and 900 m.y. (For details, see p. 53.) Further, the upper part of the Precambrian Z supracrustal rocks in the Central Appalachians has been dated at 820 m.y.; these rocks lie on Precambrian Y infracrustal rocks with the greatest discordance in the sequence below the Triassic. It would be intolerable to place this discordance, along with the infracrustal rocks below and the supracrustal rocks above, all in Precambrian Y. The proposed boundary at $800 \mathrm{~m} . \mathrm{y}$. is therefore ignored on both the Geologic Map and in the ensuing text, where the most workable boundary is found to be about 100 m.y. earlier.

\section{REPRESENTATION OF PRECAMBRIAN ON GEOLOGIC MAP OF UNITED STATES}

The interim subdivisions of Precambrian W, X, Y, and $\mathrm{Z}$ are used on the Geologic Map to classify the units in the different sequences, and to correlate these sequences with those in other parts of the country. Different categories of rocks are indicated in the same manner as in the Phanerozoic. Each Precambrian subdivision thus contains representatives of stratified sedimentary rocks, volcanic rocks, plutonic or intrusive rocks, and metamorphic rocks, shown in separate columns in the legend. However, Precambrian continental and eugeosynclinal deposits are either not separated or not recognized.

The arrangement of the stratified rocks in the legend indicates that in at least some areas the methods used in the Phanerozoic can be applied; the Belt Supergroup of Precambrian Y can even be subdivided on the Geologic Map in parts of northwestern Montana and northern
Idaho. Because the assignment of strata to one of the new subdivisions or another will not be familiar to most users, representative units in different areas are listed more completely in the legend than for the subdivisions of the Phanerozoic rocks. The volcanic rocks, although placed in a separate column in the legend, are important components of the stratified sequences in some areas, as in Precambrian W and Y of the Lake Superior Region, and Precambrian $\mathrm{Z}$ of the Appalachian Region.

Among the Precambrian plutonic rocks the most extensive are granitic, but mafic categories are separately shown in Precambrian W and Y. Assignment of the plutonic rocks to one subdivision or another is based partly on their geologic relations to the surrounding country rocks, but more upon their radiometric dating. The ages determined for the granitic rocks indicate that many of them formed during the later stages of a subdivision, but in Precambrian Y an earlier suite is extensive; the granites of Precambrian W include both the terminal plutonics, and undifferentiated earlier ones.

The metamorphic rock units, in general, are complexes so greatly altered as to preclude the application of normal stratigraphic analysis. The orthogneisses originated from plutonic rocks and the paragneisses from sedimentary or volcanic rocks. In places, the latter include some bodies of rock capable of more detailed analysis, but in such small areas that it would be fruitless to separate them on the scale of the present geologic map. On the map, the ages assigned to the metamorphic rocks are based primarily on their time of metamorphism, assuming that the original rocks were mostly formed during the time of the same subdivision, but in places they may include relict rocks formed during earlier subdivisions that have been overwhelmed by the later and dominant metamorphic event.

These results are summarized on the accompanying maps (fig. 2-5), which show the surface distribution of rocks of the different major subdivisions, as represented on the Geologic Map. To give added meaning to the figures, the rocks of each subdivision are divided into three classes: (1) Sedimentary and volcanic supracrustal rocks (including their metamorphic equivalents in the earlier subdivisions), ${ }^{2}$ (2) intrusive and plutonic rocks (including those of both felsic and mafic composition), and (3) metamorphic rocks (paragneisses and orthogneisses).

${ }^{2}$ The word "supracrustal" has been defined briefly as referring to "rocks that overlie the basement." In this account, the term supracrustal is used for Precambrian sedimentary and volcanic rocks that were laid down on the surface of the earth, on a basement of rocks that have had a more complex metamorphic and plutonic history. Ideally, they are exemplified by such units as the little deformed or metamorphosed Keweenawan and Belt Supergroups. However, differences between "supracrustal" and "basement" rocks are relative, and distinctions between them become subjective and blurred in places. Thus, this account describes many units as "supracrustal" even though they have been deformed and metamorphosed, because they are clearly of sedimentary and volcanic origin, and contrast with more enigmatic paragneisses and orthogneisses. 


\section{EXPOSED PRECAMBRIAN ROCKS OF THE UNITED STATES ${ }^{3}$}

The following is a survey of the Precambrian rocks exposed at the surface in the United States, to explain the representation adopted on the Geologic Map. It expands the explanation of these rocks in the legend. In the legend, the rocks are categorized by age and character (sedimentary, volcanic, plutonic, etc.); here, it is better to treat all the rocks of each province collectively, in order to demonstrate their mutual relations, and the reasons for assigning particular rock units to one or another of the broad age divisions.

The exposed Precambrian rocks are only a small part of the Precambrian of the United States; much larger areas are concealed beneath Phanerozoic rocks, especially in the Central Interior Region, between the Appalachian and Cordilleran mountain belts, where they are known from drill data. The concealed Precambrian rocks have been extensively investigated, especially during a project of Goldich, Muehlberger, Lidiak, and Hedge (1966). Here, these concealed rocks will be mentioned only to suggest connections between the rocks of the various areas of exposure.

In this account the results of many fundamental pieces of research will be summarized, but these are not always credited with a citation. Literature references are made primarily: (1) to recent publications that update the earlier records, (2) to summary reviews that contain references to earlier publications, and (3) to publications which contain information on radiometric dating. The account is illustrated in part by maps and diagrams, the maps being mostly on scales larger than those of the Geologic Map, which show rock units, structures, and the names of localities which could not be represented on the Geologic Map itself. Features not illustrated by the maps and diagrams in the text are believed to be adequately represented on the main Geologic Map, to which the reader should refer.

Extensive use will be made of radiometric data to justify the classifications and correlations that are made, and specific ages are cited where appropriate. In general discussions, however, I believe it is clearer to use names rather than numbers for the broad groupings of ages within a few hundred million years of each other that express orogenic, plutonic, metamorphic, or other significant events in the Precambrian history of North America. For this purpose the names used in the Canadian Shield are adapted in this text: The Kenoran with ages around 2,500 m.y., the Hudsonian with ages

${ }^{3}$ Previous official reviews of the Precambrian of the United States by Van Hise (1892) and Van Hise and Leith (1909) appeared more than half a century ago. They provide interesting comparisons with the present review, both in the amounts of data available, and in geologic concepts. around 1,700 m.y., the Elsonian with ages around 1,300 m.y., and the Grenvillian with ages around 1,000 m.y. It is true that in the United States various local names have been used for comparable events, some proposed earlier, some later; for example, Algoman and Penokean orogenies in the Lake Superior Region, St. Francois igneous activity and Llano orogeny in the South Central States, and Black Hills and Mazatzal orogenies in the Cordilleran Region. These names add precision to local discussions because they can be tied to specific dates within the particular area, but in a regional review such as this they obscure the broader relations.

\section{LAKE SUPERIOR REGION ${ }^{4}$}

The most extensive outcrops of Precambrian rocks in the United States are in the region west and south of Lake Superior. Precambrian forms the northern half of Minnesota, the western half of the northern peninsula of Michigan, and a large part of northern Wisconsin. Also properly part of the region are outlying areas to the south, such as that of ancient gneisses in the Minnesota River valley, of Sioux Quartzite that extends into South Dakota, and of Baraboo Quartzite in central Wisconsin. The region is a southern extension of the Canadian Shield, the northwestern part belonging to its Superior province, and the southeastern part to its Southern province.

The Lake Superior Region in the United States and adjacent Canada has been one of the longest known and most intensively studied Precambrian terranes in North America, particularly because of its wealth of mineral resources such as the great deposits of iron ore north and south of the lake and the copper deposits of the Keweenaw Peninsula. Moreover, it contains a long record of Precambrian rocks and events, all the major divisions (W, X, Y, and Z) being represented in some form or another. Their various supracrustal sequences total more than $150,000 \mathrm{ft}(46,000 \mathrm{~m})$ of strata, and the record is further diversified by several times of major or minor orogeny, and of plutonic and volcanic activity. The Precambrian rocks and structures have remained virtually untouched by Phanerozoic disturbances, in contrast to the Precambrian of most of the other regions of the United States which we will consider later.

For these reasons, there has long been a temptation to regard the Precambrian sequence of the Lake Sueprior Region as the North American standard, to which the Precambrian of other regions is to be compared and correlated. This view, however, would fail to take into

${ }^{4}$ For a recent compendium of the geology of the part of the Lake Superior Region in Minnesota, see Sims and Morey (1972, especially p. 27-455). This includes recent data not available when the present summary was prepared; the more important revisions are included here. 


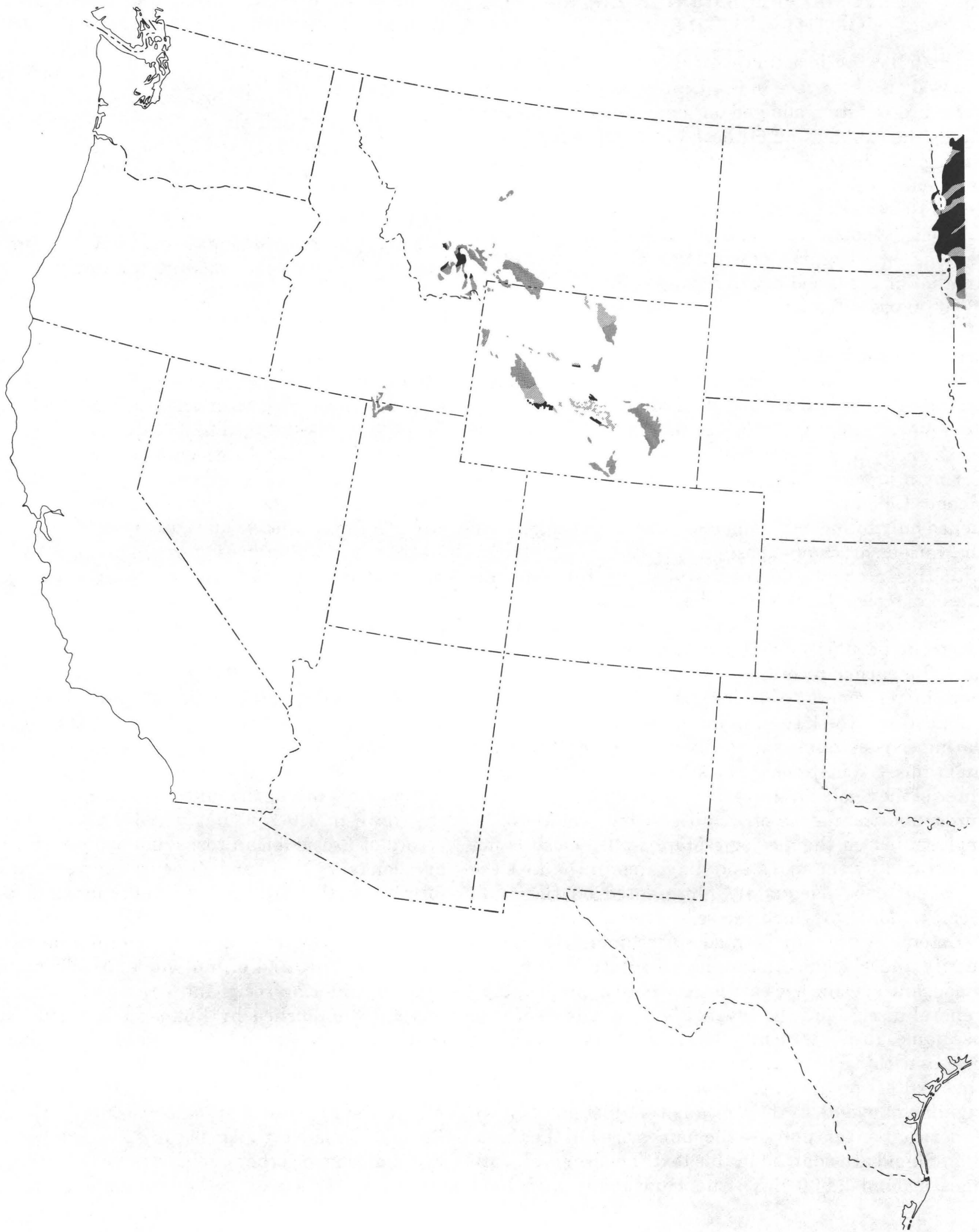

FIgURE 2.-Map of the United States, showing surface distribution of rocks of Precambrian W as represented on the Geologic Map of the United States. 


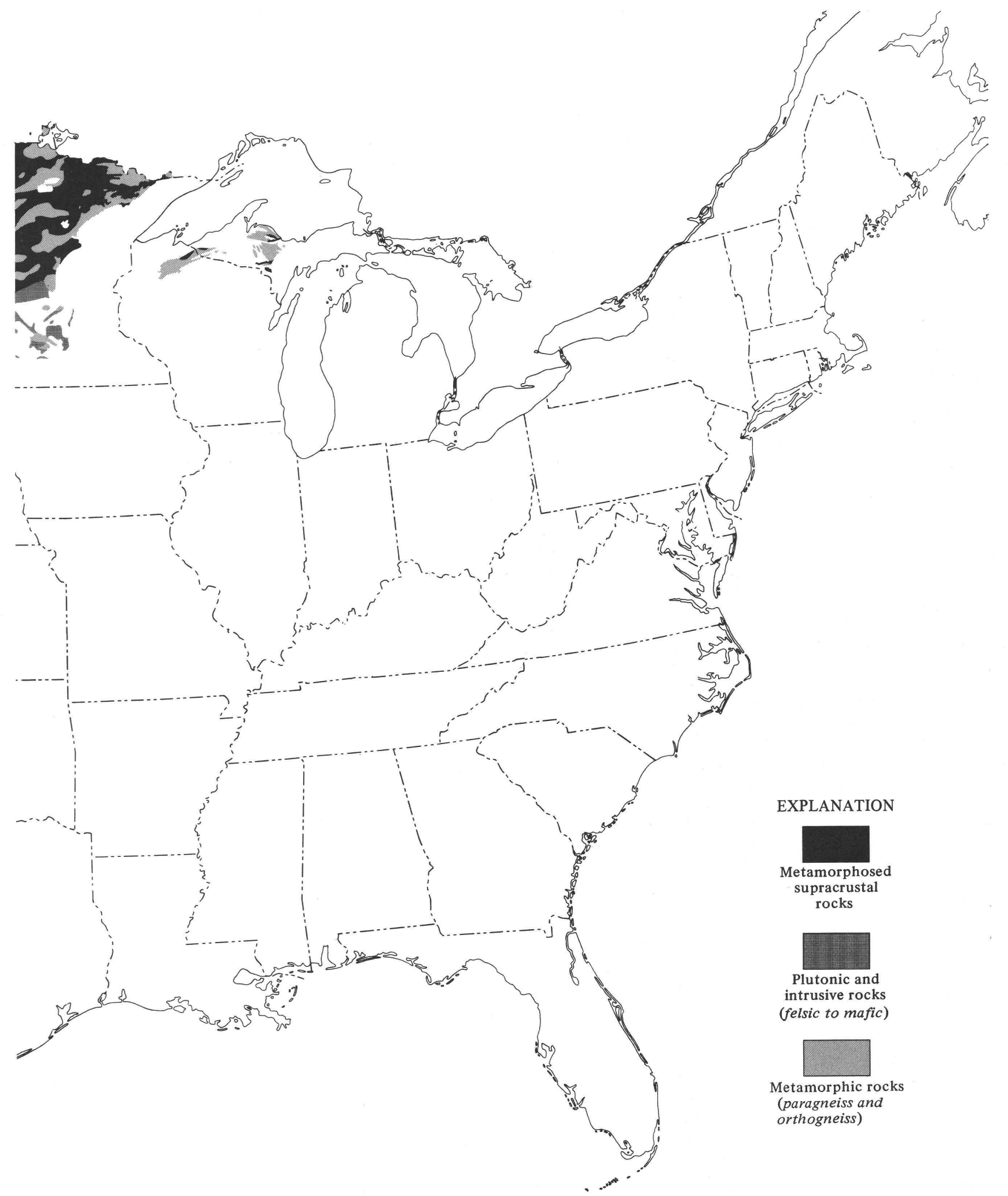

FIGURE 2.-Continued. 


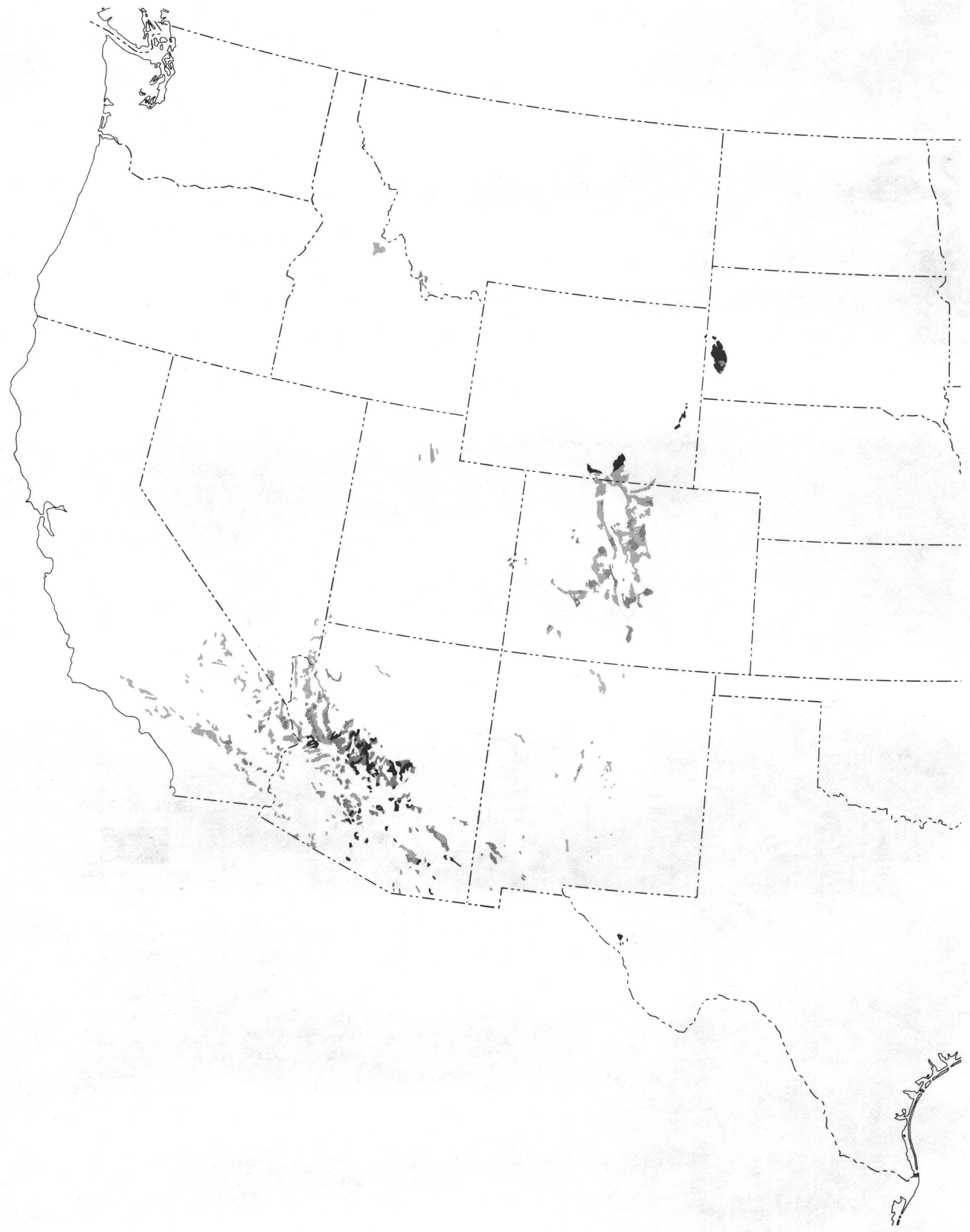

Figure 3.-Map of the United States, showing surface distribution of rocks of Precambrian X as represented on the Geologic Map of the United States. 


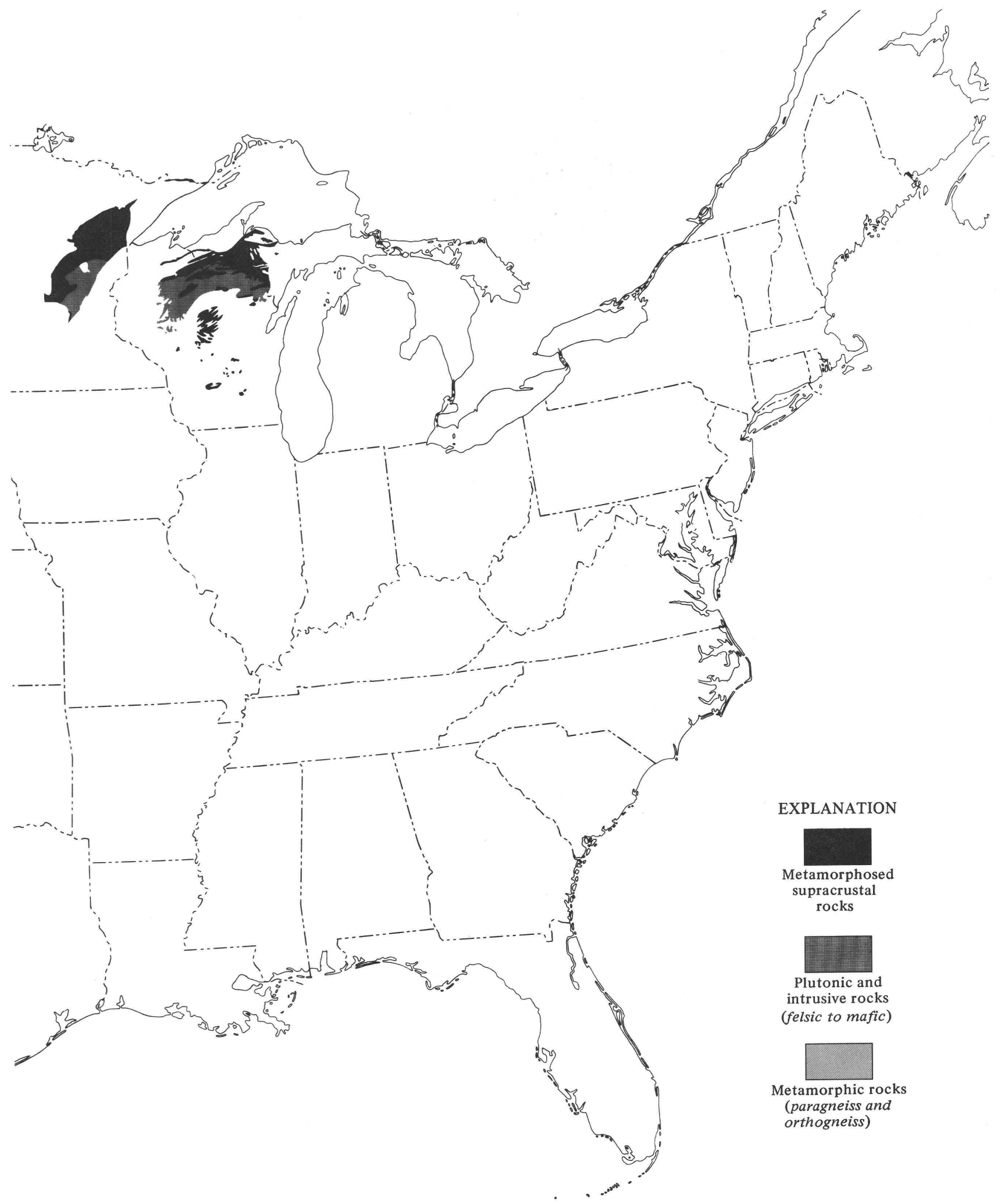

Figure 3.-Continued. 


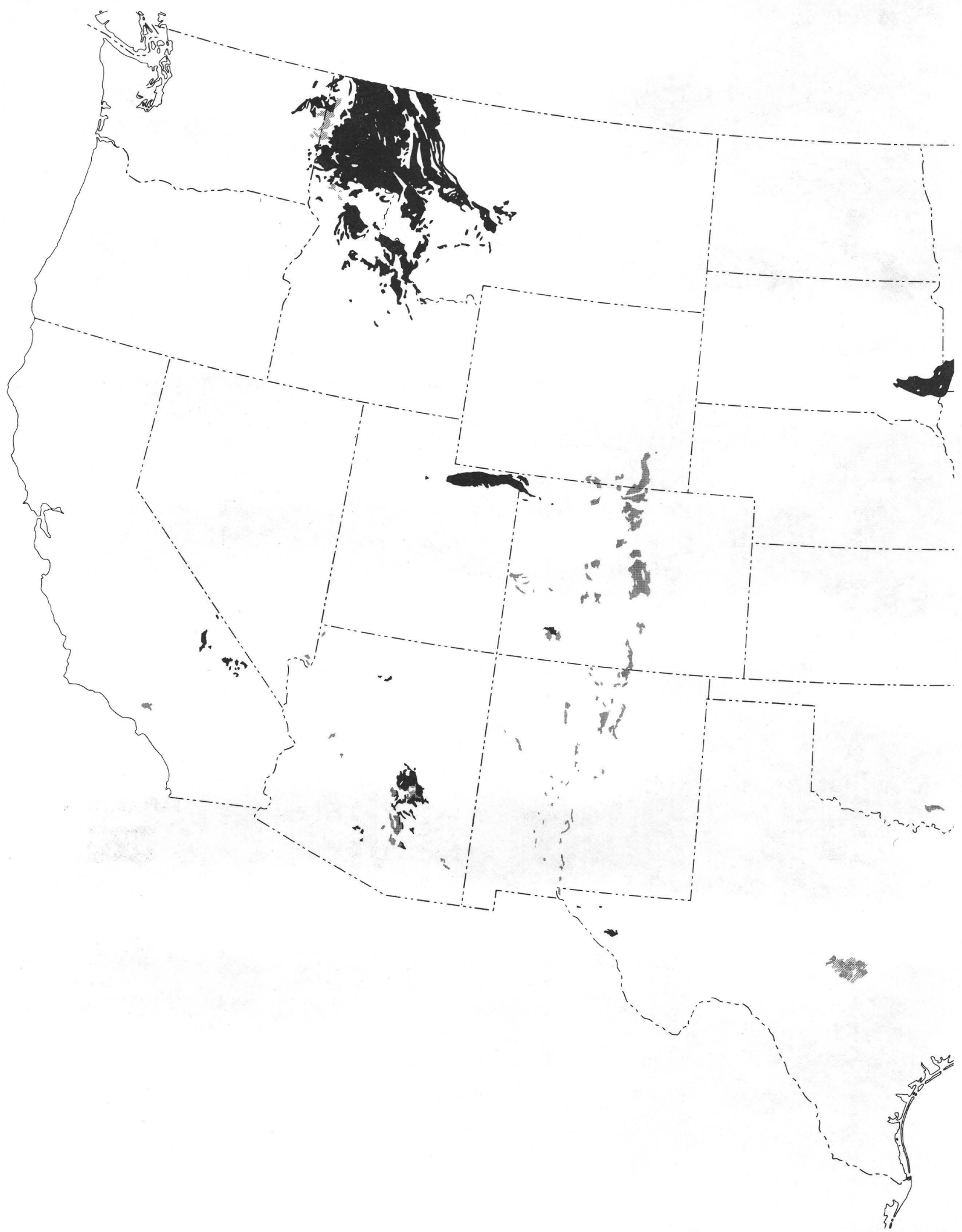

FiguRE 4.-Map of the United States, showing surface distribution of rocks of Precambrian Y as represented on the Geologic Map of the United States 


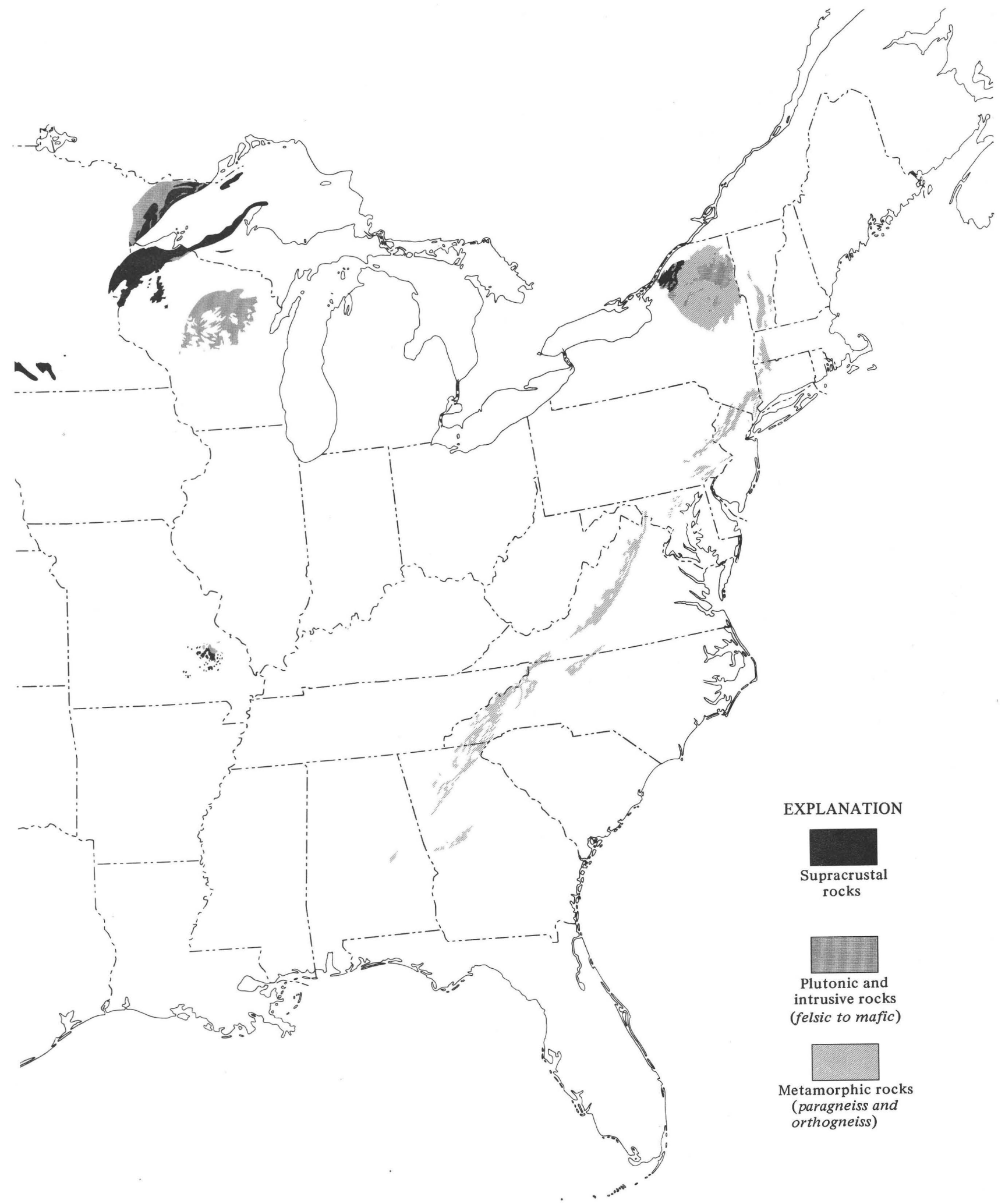

FIGURE 4.-Continued. 


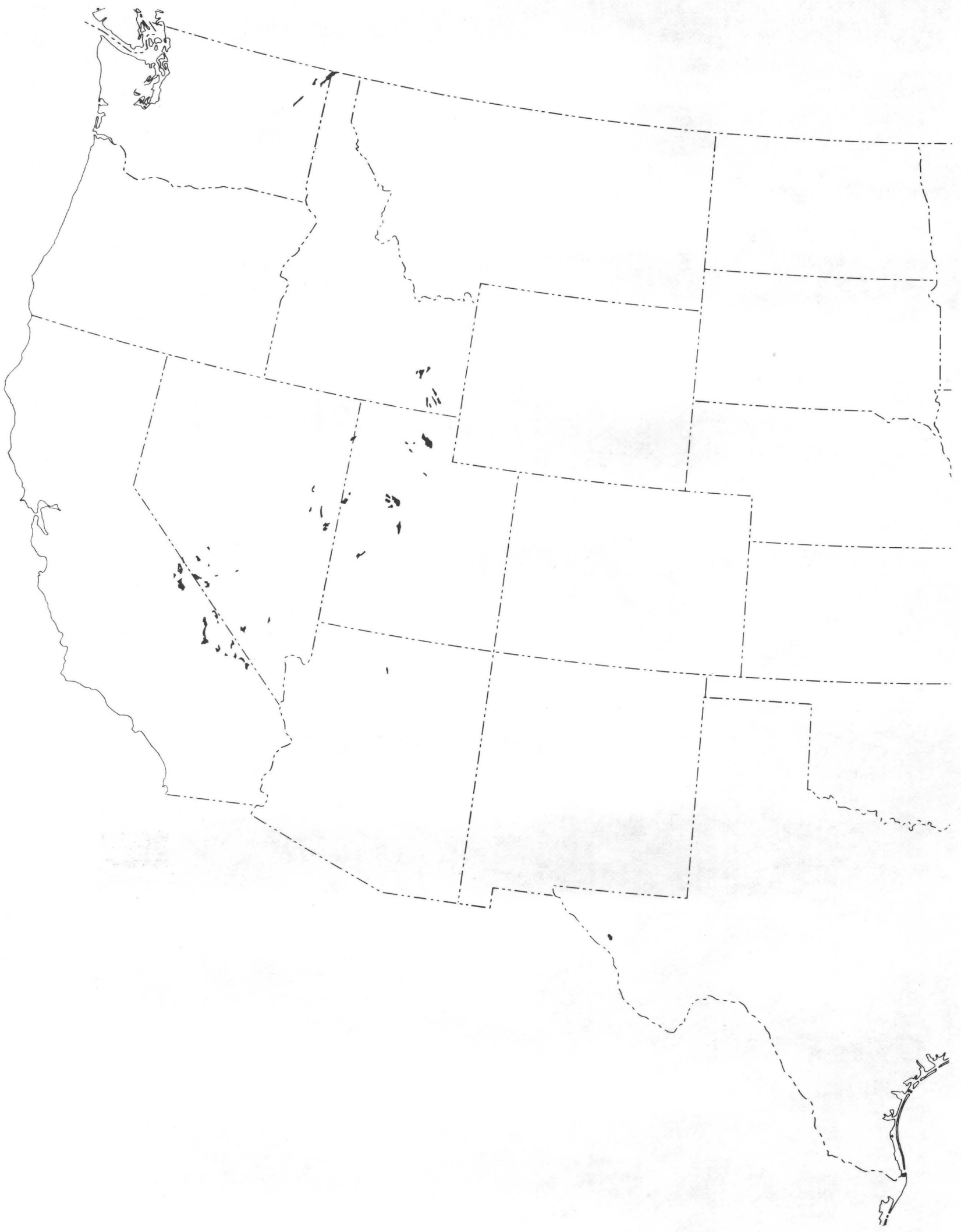

FIGURE 5.-Map of the United States, showing surface distribution of rocks of Precambrian Z as represented on the Geologic Map of the United States. 


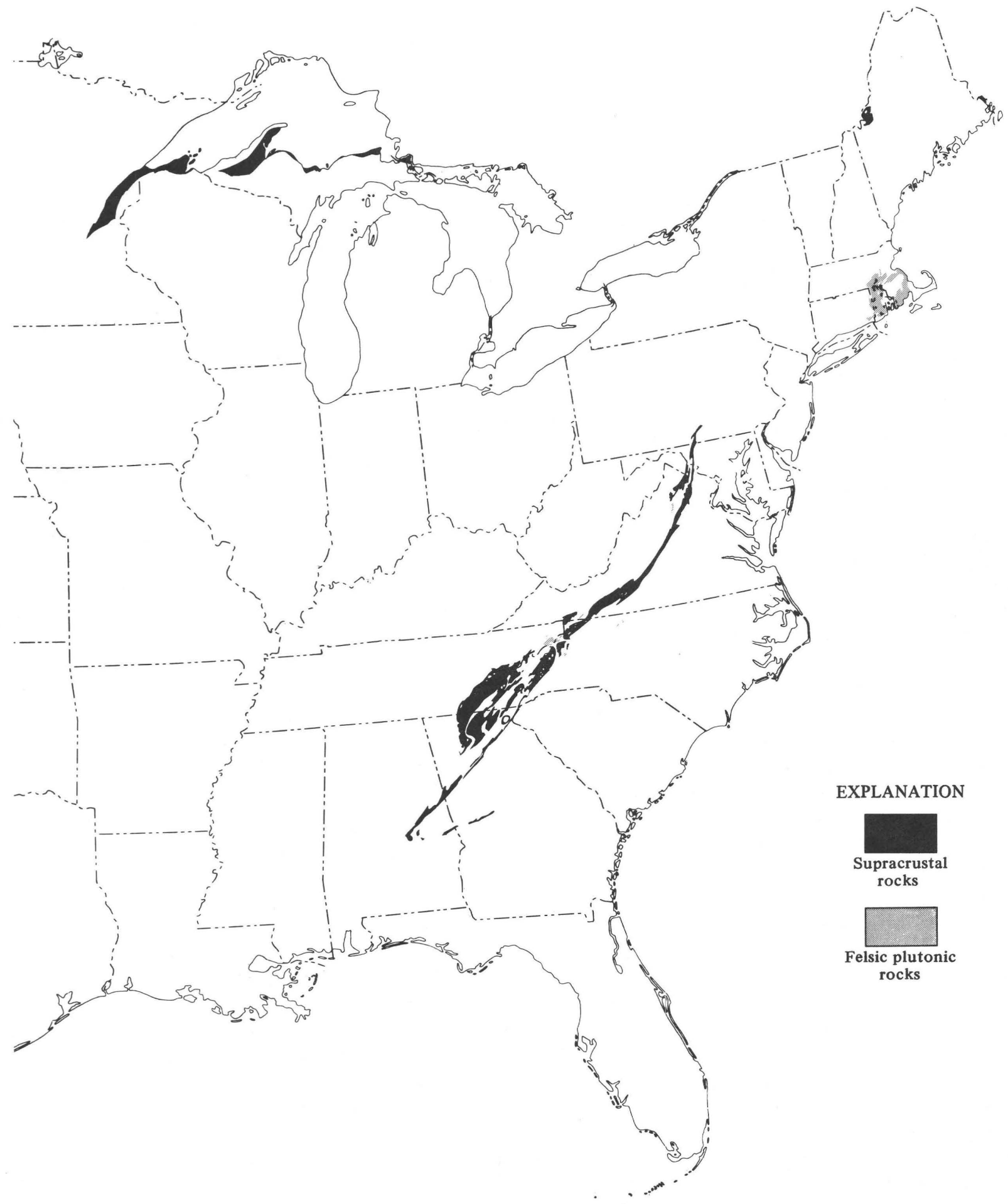

Figure 5.-Continued. 
account the great length of Precambrian time and large gaps in the record in even so complete a sequence, as well as the quite different tectonic and sedimentary regimes in other parts of North America.

\section{PRECAMBRIAN W.}

The northwestern and western part of the Precambrian area in Minnesota is an extension of the Superior province of the Canadian Shield, a domain of the ancient rocks of Precambrian $\mathrm{W}$ age (= Archean of Canada). Its rocks are well exposed toward the northeast, as well as westward along the Canadian border as far as the Lake of the Woods. Farther southwest outcrops are sparse; there is an extensive cover of thick glacial drift and of the thin intervening Cretaceous Coleraine Formation (King and Beikman, 1974, fig. 13), so that representation of the Precambrian here must be largely by subcrop methods, especially by deductions from geophysical surveys.

The Superior province in Minnesota (as in adjoining Ontario) is a great body of supracrustal rocks, probably more than $50,000 \mathrm{ft}(15,000 \mathrm{~m})$ thick in all, partly metavolcanics $(\mathrm{Wv})$, partly metasediments $(\mathrm{W})$, and equally extensive bodies of granitic plutonic rocks $(\mathrm{Wg})$.

The volcanics, traditionally called Keewatin Group, include the Ely Greenstone of northeastern Minnesota with the Soudan Iron-formation in its upper part (commercially productive in the Vermillion district). Much of the greenstone is basaltic, but intermediate and felsic varieties are present also. Pillow structure is ubiquitous, except where obscured by deformation and metamorphism, and indicates subaqueous eruptions. The superincumbent sediments-the Knife Lake Group of northeastern Minnesota and comparable units in Ontario (Temiskaming, etc.) —are dominantly graywacke, with local thick lenses of conglomerate and minor slate; quartzite and limestone are virtually lacking. Graded bedding and related features in the graywackes indicate they they are turbidites, formed subaqueously in a tectonic environment (Pettijohn, 1943, p. 966-968).

The relation of the sediments to the volcanics has been variously interpreted ever since A. C. Lawson began fieldwork in the Lake of the Woods area in 1883, and has given rise to some 0 the classic controversies of North American geology. It is now clear that most of the sediments overlie the volcanics, but a prevolcanic terrane (Coutchiching) has been claimed, especially in adjacent Ontario. In places, at least, the superincumbent sediments lie unconformably on the volcanics, and some granites intrude the volcanics but not the sediments, giving rise to the concept of a far-reaching "Laurentian orogeny" between the two. Actually, these problems are not fundamental, as volcanic and sedimentary units are probably intermingled in various combinations from place to place (Pettijohn, 1943, p. 980-981). Unconformities above the volcanics are of local extent, and gradational or interbedded relationships occur in other places.

A case in point is stratigraphic relations in the Vermillion district of north-eastern Minnesota, where many of the classic concepts of the Precambrian W rocks originated. Modern mapping (Sims, in Sims and Morey, 1972 , p. 49-62) has indicated greater stratigraphic complexity than originally supposed; in essen ze, the Ely Greenstone (or local representative of the Keewatin Group) is followed by a unit of Knife Lake sediments, and this by a second volcanic body of Keewatin type, the last two merging into the main mass of Knife Lake sediments in the eastern part of the district. The whole sequence is conformable, and there is no evidence for any major orogenic interruption, as was formerly believed.

Of the older granites (traditionally but inappropriately called "Laurentian") the only example that has been cited in Minnesota is the Saganaga Granite on the International Boundary in the northeastern corner of the State (fig. 6). It clearly intrudes the Ely Greenstone, and the adjacent Knife Lake sediments lie on its eroded surface. However, it intrudes other parts of the Knife Lake, and its radiometric age does not differ greatly from that of the surrounding rocks. Probably its pluton was emplaced at shallow depths, and quickly unroofed during the early part of Knife Lake sedimentation (Sims, in Sims and Morey, 1972, p. 53).

The remaining granites (termed Algoman) intrude all the supracrustal rocks of the province: The Vermillion Granite forms a body $80 \mathrm{mi}(130 \mathrm{~km})$ long east-west and $30-40 \mathrm{mi}(50-65 \mathrm{~km})$ wide north-south along the International Boundary, and the Giants Range Granite farther south extends for more than $100 \mathrm{mi}(160 \mathrm{~km})$ along the northern edge of the Mesabi Range, where it is overlain unconformably by the Animikie Group (Precambrian X).

The Algoman (= Kenoran) orogeny deformed and metamorphosed the supracrustal rocks and emplaced the Algoman granites. The orogeny has been dated between 2,400 and 2,750 m.y., on the basis of a variety of radiometric methods (Goldich and others, 1961, p. 6974). However, there are unexplained discrepancies between uranium-lead, rubidium-strontium whole-rock, potassium-argon and rubidium-strontium mineral ages. Available radiometric data seem to suggest that all of the features in the Precambrian W complex of northern Minnesota-accumulation of the volcanics and sediments, and their deformation, metamorphism, and plutonism-were created during a remarkably 


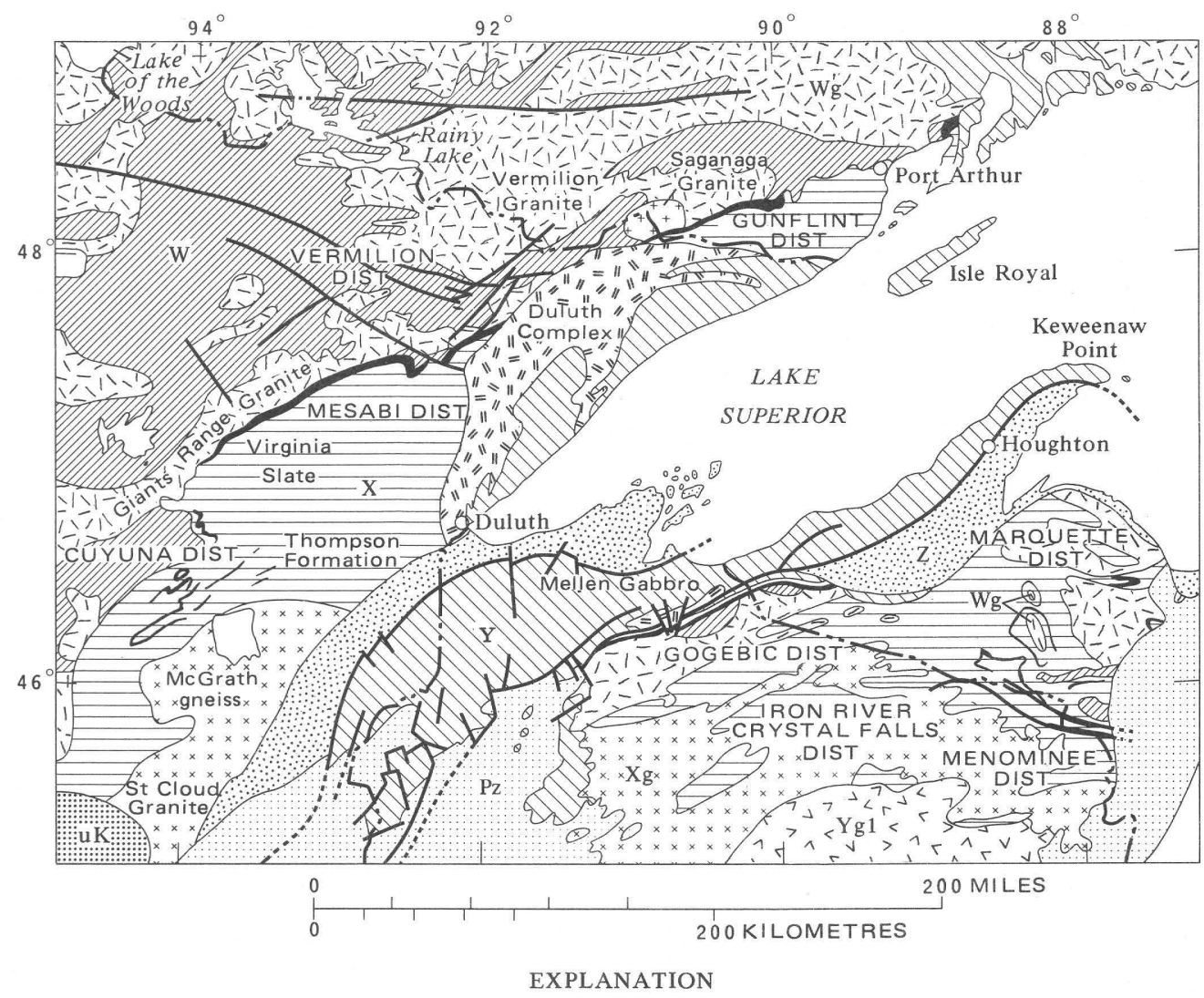

SUPRACRUSTAL ROCKS

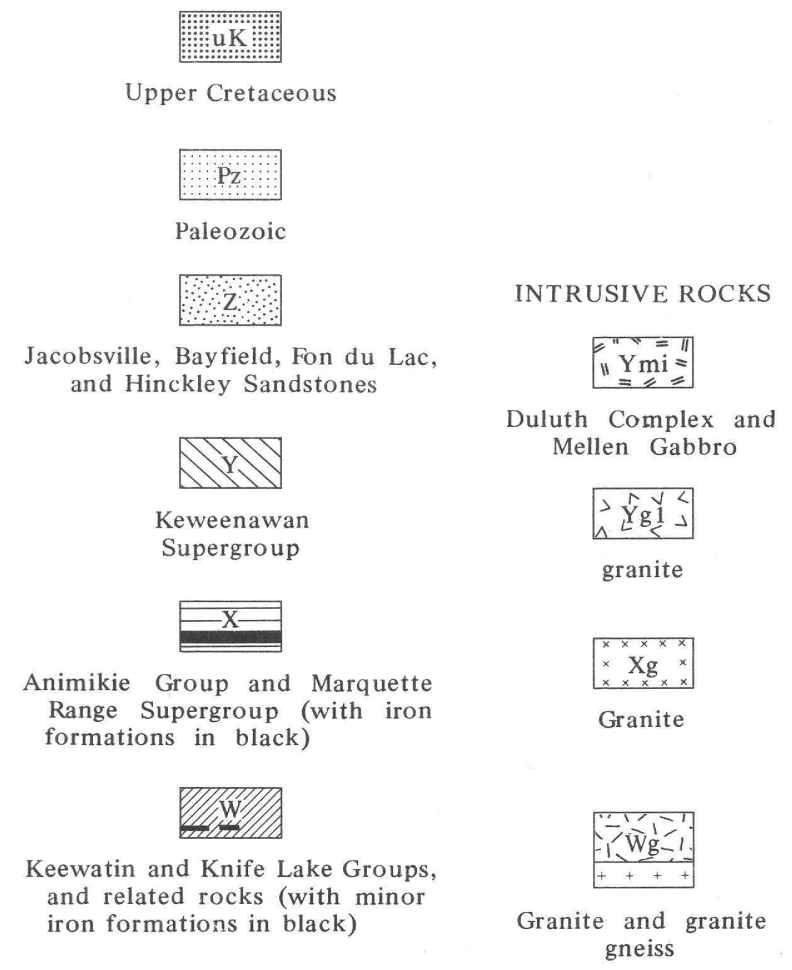

FIGURE 6.-Geologic map of part of the Lake Superior Region, showing localities and map units mentioned in the text. Generalized from geologic maps of United States (1974) and Canada (1969). 
short interval between 2,700 and 2,750 m.y. ago (Goldich, in Sims and Morey, 1972, p. 32-34).

South of the area just discussed, in southwestern Minnesota, Precambrian granites and gneisses (Wg, Wgn) appear along the Minnesota River valley (Goldich and others, 1961, p. 123-146). Here, radiometric determinations have yielded a scatter of dates, with some as low as 1,850 m.y. (an overprint of the Penokean (= Hudsonian) event), and others, by lead-lead methods on zircons from 2,870 to 3,280 m.y. A concordia plot suggests an original age of 3,550 m.y. (Goldich, 1968, p. 718-720), so that these rocks are among the oldest recorded in North America. ${ }^{5}$

South of Lake Superior in Michigan and Wisconsin, old rocks are exposed beneath the Marquette Range Supergroup (Precambrian X) in the higher folds, and have been identified as "Archean" (that is, Precambrian W) since the earliest surveys. Most of the rock is granite gneiss, probably mainly Algoman, but Keewatin-type greenstone occurs to the north in the Marquette district, and farther south is the Dickinson Group of arkose, schist, and amphibolite (fig. 2); it is in contact not only with the Algoman granite, but with an older granite gneiss (James, 1958, p. 31-33). This region has been more heavily involved in younger Precambrian events (such as the Penokean orogeny) than the region northwest of Lake Superior, so that radiometric dating has produced varied results. Nevertheless, feldspar rubidium-strontium ages and the diffusion age of zircons establish the age of the basement gneisses at near 2,700 m.y. (Aldrich and others, 1965, p. 462), or about as old as the Precambrian W rocks of northwestern Minnesota.

Gneisses east of the Minnesota River valley (the McGrath Gneiss of central Minnesota and the basement gneisses of Michigan and northern Wisconsin) are similar petrographically and in metamorphic history to those along the Minnesota River but have so far failed to yield dates as ancient. Nevertheless, Morey and Sims (1976) suggest that they may all be part of the same terrane-a sialic protocontinent against which the greenstones and graywackes of northern Minnesota and elsewhere in the Superior province were built in later Precambrian W time.

\section{PRECAMBRIAN X}

Southeast of the Superior province is the Southern province, which forms the remainder of the Lake Superior Region. The boundary between them is in north-

\footnotetext{
${ }^{5}$ The oldest radiometrically dated rocks in North America, and among the oldest in the world, are those of the Godthaab area, western Greenland, where quartzo-feldspathic gneisses with some shreds of iron formation have been dated at more than 3,750 m.y. (Moorbath and others, 1972). Very ancient Precambrian rocks are suspected from geological evidence in parts of the Canadian Shield in Canada, but so far lack radiometric verification.
}

ern Minnesota and adjacent Ontario, where rocks of Precambrian $\mathrm{X}$ lie with right-angle unconformity on rocks of Precambrian W and dip away from them southeastward. Within the Southern province, rocks of Precambrian $\mathrm{X}$ are extensive northwest and south of Lake Superior, in Minnesota, Wisconsin, and Michigan, flanking on each side the Keweenawan rocks (Precambrian Y) that occupy the trough of the Lake Superior syncline. They contain all the commercially exploited iron deposits of the Lake Superior Region (shown in red on the Geologic Map), except those in Precambrian W of the Vermillion district: the Gunflint district of Ontario, the Mesabi and Cuyuna districts of Minnesota, and the Gogebic, Menominee, Marquette, and other districts of Wisconsin and Michigan (fig. 1). (The outcrops of iron formations in the various districts are commonly referred to as "ranges," hence such terms as "Mesabi Range.")

The supracrustal rocks of Precambrian X northwest of Lake Superior are the Animikie Group, named long ago for the Thunder Bay district in Ontario, whence the group can be traced westward with little interruption into Minnesota. South of Lake Superior, the obvious stratigraphic and lithologic equivalents of the Animikie are in the middle of a more comprehensive sequence, the Marquette Range Supergroup (Cannon and Gair, 1970) (fig. 7).

The Animikie of the northwestern area begins with a discontinuous basal quartzite lying unconformably on Precambrian W, followed by a persistent iron formation several hundred feet thick (Biwabic of Mesabi district), and topped by the Virginia Slate many thousands of feet thick. This iron formation (and those of Precambrian X elsewhere) is an alternation of ferruginous chert (= taconite), slate, and stromatolitic beds, whose weathered products were the readily exploited iron deposits of past decades. The Virginia Slate is interbedded argillite and graywacke, a turbidite deposit not unlike the much older Knife Lake.

In the Cuyuna district southwest of the Mesabi district the sequence is much the same, but the iron formation is separated from the Precambrian $\mathrm{W}$ rocks on the west by á poorly exposed, wider stratigraphic interval. It may include pre-Animikie Precambrian X rocks comparable to the Chocolay Group south of Lake Superior (Marsden, in Sims and Morey, 1972, p. 227-230).

These lithologic components reappear in the Marquette Range Supergroup south of Lake Superior. Iron formations like the Biwabik occur in each of the principal districts (Gogebic, Marquette, Menominee), again with basal quartzites and great overlying bodies of "slate" (argillite and graywacke). Here, however, the sequence is thicker, more diverse, and interrupted by unconformities, so that it has been divided into four 


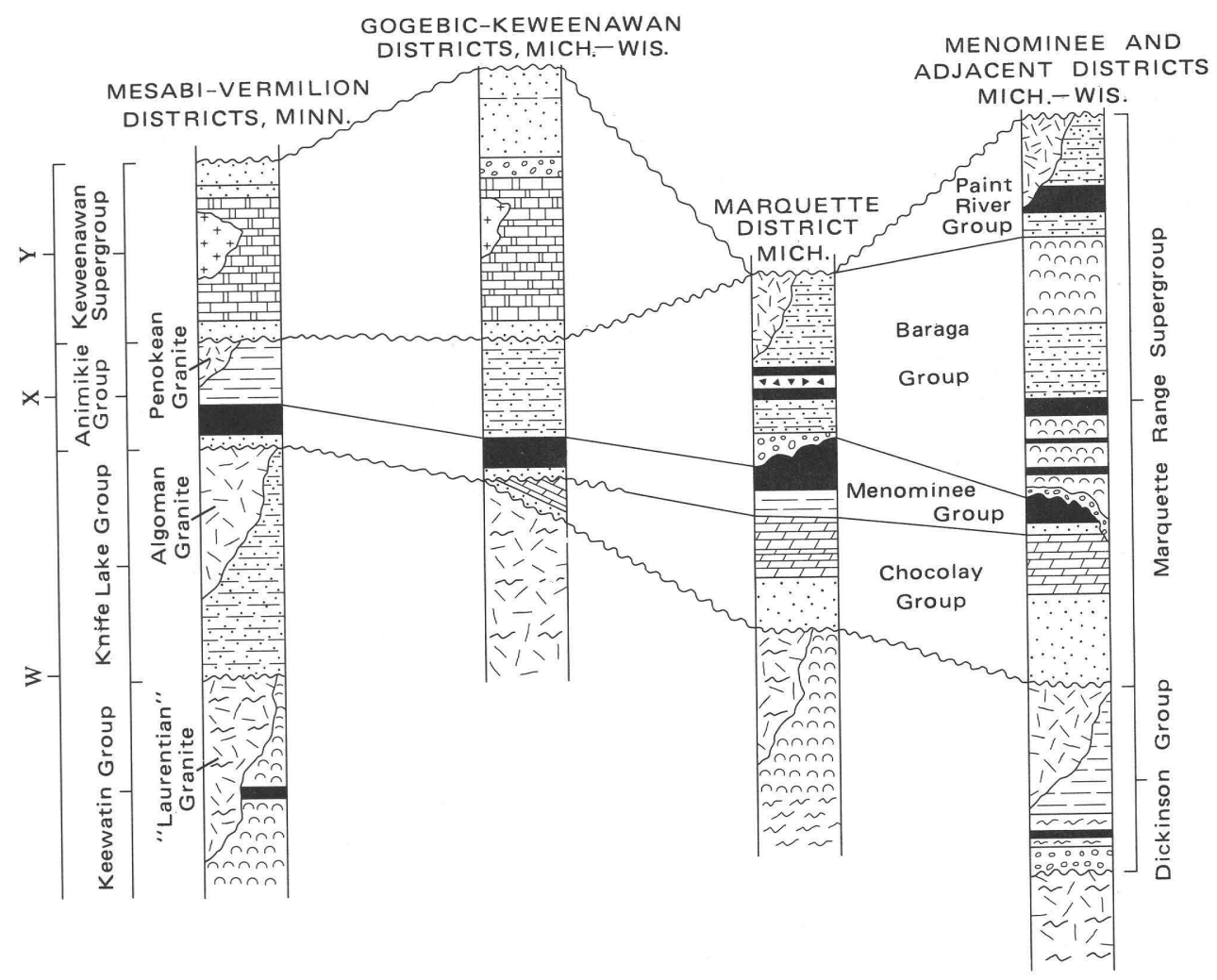

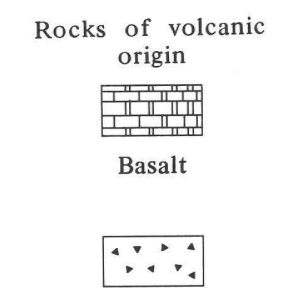

Greenstone tuff and breccia

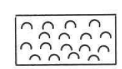

Greenstone, in part with preserved pillow structures

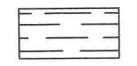

Amphibolite of basaltic composition

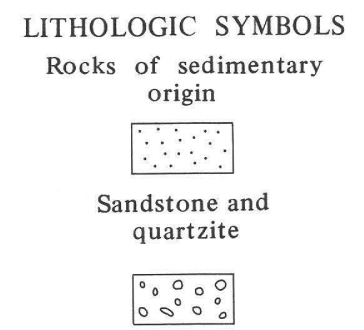

Conglomerate, conglomeratic sandstone, and arkose

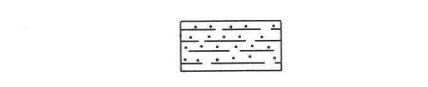

Graywacke, shale, argillite, slate, and schist

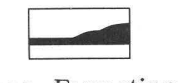

Iron Formation

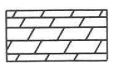

Dolomite

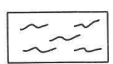

Schist; probably includes some rocks of volcanic origin
Crystalline rocks, mostly of igneous origin

$$
\mathrm{C}_{+}^{+}+{ }_{+}^{+}+{ }_{+}^{+}+
$$

Gabbro and granite Age $1,100 \mathrm{~m} \cdot \mathrm{y}$.

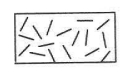

Granitic rocks Age $1,600-1,900 \mathrm{~m} \cdot \mathrm{y}$.

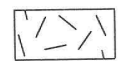

Gneissic granite Age $2,600 \mathrm{~m} \cdot \mathrm{y}$

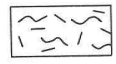

Granitic gneiss Age 2,600 m.y. or older

FIGURE 7.-Stratigraphic chart showing Precambrian units northwest and south of Lake Superior in Minnesota, Michigan, and Wisconsin. Thicknesses are diagrammatic, and not to scale. After Bayley and James p. 936). 
groups: the Chocolay, Menominee, Baraga, and Paint River (James, 1958, p. 30) (fig. 7). The Chocolay at the base is quartzite and dolomite. The Menominee above it contains the great iron formations, and the Baraga the great "slate" bodies (Tyler, Michigamme); the latter is diversified further by thick but impersistent bodies of pillow lava. The Paint River at the top, preserved only in the deeper downfolds, is again slate and graywacke, with its own productive iron formation (Riverton) in the Iron River-Crystal Falls district. The whole sequence, totaling at least $50,000 \mathrm{ft}(15,000 \mathrm{~m})$, exhibits an upward progression from shelf or miogeosynclinal deposits below, with quartzites, dolomites, and iron formation; into eugeosynclinal deposits above, with argillites, graywackes, and pillow lavas.

The Animikie Group and Marquette Range Supergroup are the "Huronian" of the older classic reports on the Lake Superior Region. The original Huronian of Logan and later Canadian geologists is in southern Ontario north of Lake Huron, and correlation of the Lake Superior rocks with it was recommended by the International Committee on the Lake Superior Region (Adams and others, 1905). Actually, the original Huronian and its supposed equivalent in the Lake Superior Region are separated by a $200-\mathrm{mi}(320-\mathrm{km})$ gap covered by younger strata, and have few physical resemblances; for example, the great iron formations of the Lake Superior Region are missing from the type Huronian. Moreover, recent radiometric work demonstrates that they are not correlative (Van Schmus, 1972). The type Huronian overlies a 2,700-m.y.-old basement and is intruded by the 2,160-m.y.-old Nipissing Diabase, whereas the Marquette Range Supergroup has been dated between 2,050 and 1,900 m.y. Both the Huronian and the Lake Superior rocks are units within Precambrian X, but the first is older than the second, their ages seemingly do not overlap, and they may be separated by a minor period of orogeny.

The Precambrian X rocks of the Lake Superior Region were variably involved in the Penokean (= Hudsonian) orogeny, a pre-Keweenawan (Precambrian $\mathrm{Y}$ ) event which is expressed by potassium-argon dates of 1,600 to 1,800 m.y. in the plutonic and supracrustal rocks, both northwest and south of Lake Superior (Goldich and others, 1961, f. 156-57; Aldrich and others, 1965, p. 463). Presently available data suggest that it is actually older than 1,850 m.y. (Goldich, in Sims and Morey, 1972, p. 35).

In northeastern Minnesota and adjacent Ontario the Animikie slopes homoclinally southeastward at an angle of only a few degrees beneath the Keweenawan-a relation that prompted Lawson (1914, p. 70) to proclaim the Animikie as the true base of the Paleozoic. The orogenic effects increase southward and southwestward. In the Cuyuna district the iron formation and associated rocks are folded, and west of the head of Lake Superior the Thompson Formation, although coextensive with the Virginia Slate, has been so strongly deformed that it has been mistaken by some geologists for the Knife Lake. In central Minnesota the Animikie belt is truncated southwestward by a complex of plutonic rocks mapped as Xg, including the McGrath Gneiss to the northeast and the Saint Cloud and other granites farther southwest (fig. 6), all of which have yielded potassium-argon dates of 1,640 to 1,760 m.y. (Goldich and others, 1961, p. 116-117). Further field and radiometric investigations indicate, however, that the McGrath is much older and probably Algoman, with a Penokean overprint. The granites farther southwest are shown by rubidium-strontium determinations to range in age from 1,730 to 1,820 m.y. (Keigan, Morey, and Goldich, in Sims and Morey, 1972, p. 252-254).

South of Lake Superior, rocks of Precambrian X and their Precambrian $\mathrm{W}$ basement have been thrown into wide steep folds and metamorphosed to greenschist or amphibolite facies (with sillimanite) (James, 1955, p. 1461-1463). In some areas there is only a slight angular discordance between the Marquette Range rocks and the Keweenawan rocks north of them, but even here the former are metamorphosed and the latter are not. Intrusive rocks are widely distributed in Precambrian X south of Lake Superior, but none attain batholithic dimensions; the granitic rocks are mostly younger than the deformation and metamorphism, but none are younger than 1,700 m.y. Contrary to previous belief, there is no post-Keweenawan "Killarney" granite in the area (Goldich and others, 1961, p. 163-164.

\section{PRECAMBRIAN OF NORTHERN WISCONSIN}

Precambrian rocks are at the surface for $130 \mathrm{mi}$ $(210 \mathrm{~km})$ south of the area just discussed, along the Wisconsin arch, but outcrops are discontinuous because of extensive glacial cover and the bedrock geology is known only in part. On most of the earlier maps the Precambrian of the arch is shown as undivided granites and gneisses, for which ages anywhere from early to late Precambrian have been proposed. Subsequently, Dutton and Bradley (1970) have assembled all the available data and have clarified the picture; their map was the chief basis for representation on the Geologic Map. After compilation and printing of the map, articles by Van Schmus and Medaris (1975a) and Van Schmus, Thurman, and Peterman (1975b) have appeared that add many new data, which would require revision of some of the boundaries shown on the map.

The oldest rocks of the area are Precambrian W granites which adjoin the Marquette Range Supergroup of 
the Gogebic district in the northwestern part of the State, but radiometric dates elsewhere are younger than Kenoran, and no Precambrian W rocks probably exist farther south.

The main body of rocks in the Wisconsin arch have yielded ages of about 1,650 m.y. by rubidium-strontium methods and 1,800 m.y. by uranium-lead methods and include belts of metasedimentary (X) and metavolcanic rocks (Xv) probably equivalent to the Marquette Range Supergroup, separated by belts of intrusive granite $(\mathrm{Xg})$.

On the southeast, however, the Wolf River batholith occupies an area of $3,600 \mathrm{mi}^{2}\left(9,300 \mathrm{~km}^{2}\right)$ and has been dated by rubidium-strontium methods at 1,468 m.y. and by uranium-lead methods at 1,510 m.y. On the Geologic Map it is classed as Yg1, or Elsonian. The batholith is a fresh, anorogenic body which crosscuts all the older rocks adjacent to it. On the Geologic Map the northern boundary of the Elsonian granites was projected hypothetically westward across the arch, but they actually have a well-defined western boundary beyond which, except for a smaller syenite body near Wasau, only older rocks of Precambrian X occur. Near Tigerton the batholith encloses an older mass of anorthosite (Ya).

The Wolf River batholith is the local representative of anorogenic plutonic intrusions of Elsonian or early Precambrian Y age ( $\mathrm{Yg}_{1}$ ) which we will observe again in the southern Interior Region, the Southern Rocky Mountains, and Arizona.

\section{KEWEENAWAN SUPERGROUP OF PRECAMBRIAN Y ${ }^{6}$}

In the Lake Superior Region, Precambrian $\mathrm{Y}$ is primarily the Keweenawan Supergroup, a great body of continental volcanics ( $\mathrm{Yv}_{\mathrm{v}}$ ) and sediments (Y), with associated mafic intrusives (Ymi), that fills the trough of the Lake Superior syncline. The Keweenawan includes the "Lake Superior sandstone" and "cupriferous trap" that intrigued the early geological explorers, some of whom correlated them with the New Red Sandstone of Triassic age. In northern Michigan the Keweenawan contains large deposits of native copper and copper sulfide that have been mined for more than a century.

The Keweenawan crops out in wide belts along both the northwestern and southeastern shores of Lake Superior in Minnesota, Ontario, Wisconsin, and Michigan, and projects into the lake in the Keweenaw Peninsula (fig. 6). It (and the overlying sandstones of Precambrian Z) forms all the islands in the lake, and also its floor. Beyond the head of the lake the synclinal belt of Keweenawan rocks extends southwestward for another hundred miles $(160 \mathrm{~km})$ until it passes beneath the overlapping Cambrian; it is even more extensive in the subsurface, as indicated below.

\footnotetext{
${ }^{6}$ For a more detailed review of the Keweenawan rocks, see Halls (1966).
}

The thickness of Keweenawan supracrustal rocks and their associated intrusives is well over $50,000 \mathrm{ft}$ $(15,000 \mathrm{~m})$ in the trough of the syncline but thins outward and may not have extended far beyond its present limits (White, 1966, p. 28-32); accumulation of the Keweenawan and downwarping of the syncline were contemporaneous. Although the rocks have been gently to steeply tilted they have not been folded or metamorphosed.

The Keweenawan sequence begins with thin basal sandstones preserved discontinuously on both the north and south flanks of the syncline. They are overlain by a great sequence of amygdaloidal basaltic to andesitic lavas in persistent thin to thick flows, with minor rhyolites (Portage Lake Group to southeast, North Shore Group to northwest). Observed sequences of the lavas are 15,000-25,000 ft (4,500-7,600 m) thick, but are incomplete and the total is clearly much greater. Flow structures in the lavas demonstrate that they spread out in both directions from the axis of the trough, against the present slope of its flanks. Evidently the rate of buildup of the lavas exceeded the rate of downwarping of the trough, and produced an outward slope (White, 1960, p. 368-371). Paleomagnetic studies indicate that the lower lava flows have reversed polarity and the uper lava flows normal polarity, which suggests a possible criterion for stratigraphic subdivision (Craddock, in Sims and Morey, 1972, p. 285-286).

Succeeding the lavas on the southeast shore are the clastic, continental sediments of the Oronto Group, as much as $15,000 \mathrm{ft}(5,000 \mathrm{~m})$ thick. The first deposits are coarse conglomerates made up largely of volcanic clasts (Copper Harbor), but the main body (Freda) is red arkosic sandstone and interbeded micaceous siltstone, derived from erosion of surrounding highlands of earlier Precambrian crystalline rocks. The thin Nonesuch Shale, which separates the lower conglomerates from the Freda, contains organic compounds, microfossils, and crude oil. Sedimentary structures in the sandstones indicate transport from the highlands toward the axis of the trough (Hamblin, 1961, p. 2-6), indicating that, unlike the volcanic buildup, the sedimentary buildup did not keep pace with the subsidence of the trough.

The lower part of the Keweenawan is invaded by mafic intrusives, the largest being the Duluth Complex northwest of Lake Superior, a lopolith $150 \mathrm{mi}(240 \mathrm{~km})$ long and as much as 50,000 ft $(15,000 \mathrm{~m})$ thick near its center, injected near the base of the Keweenawan. It is a multiply-layered intrusive, mainly gabbro but with anorthositic phases, and a granophyre phase at the top. Smaller mafic bodies south of Lake Superior are at about the same stratigraphic level, the largest being the Mellen Gabbro of the Gogebic district (fig. 6). The intrusives are deep-seated manifestations of the same 
"Keweenawan igneous activity" that produced the lavas.

Radiometric dates of the Keweenawan rocks have been obtained from the felsic differentiates of the mafic intrusives and lavas. Felsites from the North Shore and Portage Lake Volcanics, the granophyric facies of the Duluth Complex and Mellen Gabbro, as well as other igneous rocks, have all yielded ages between 1,120 and 1,140 m.y. by uranium-lead determinations on cogenetic zircons, suggesting a narrow pulse of magmatic activity (Silver and Green, 1963, 1972). Dates by potassium-argon and rubidium-strontium methods have a greater span, between 1,100 and 1,300 m.y. (Goldich and others, 1961, p. 95; Goldich, in Sims and Morey, 1972, p. 35-36), but are less reliable. An age of 1,075 m.y. has been proposed for the Nonesuch Shale of the succeeding Oronto Group (Craddock, in Sims and Morey, 1972, p. 185).

The Lake Superior syncline and its Keweenawan rocks are merely an exposed segment of a much larger tectonic feature (fig. 8). Prominent gravity and magnetic anomalies demonstrate that the trough and its associated mafic igneous rocks extend another $600 \mathrm{mi}$ $(960 \mathrm{~km})$ southwestward beneath the Paleozoic cover into northeastern Kansas (E. R. King and Zietz, 1971), and somewhat vaguer geophysical data suggest that the trough turns southeastward near the end of Lake Superior, to extend for an unknown distance beneath the southern peninsula of Michigan (Oray and others, 1973). The whole structure thus has a curiously arcuate form, concave toward the south-a product of crustal rifting of subcontinental dimensions late in Precambrian time.

\section{PRECAMBRIAN Y ROCKS OLDER THAN KEWEENAWAN}

Southwest of the Keweenawan area is the Sioux Quartzite of southwestern Minnesota and southeastern South Dakota which forms a plateaulike terrain $200 \mathrm{mi}$ $(320 \mathrm{~km})$ long, partly concealed by glacial drift; the similar Barron Quartzite forms a smaller area on the west flank of the Wisconsin arch. The Sioux is warped gently into an axial trough and has a thickness of about $3,000 \mathrm{ft}(900 \mathrm{~m})$; the Barron is much thinner. Interbedded in the Sioux are layers of "pipestone" (argillite) which have yielded potassium-argon date of 1,200 m.y. (Goldich and others, 1961, p. 49), probably related to the mild deformation. A well in northwestern Iowa penetrated Sioux Quartzite interbedded with rhyolite layers, the latter yielding an apparent rubidiumstrontium age of 1,470 m.y. (Austin, in Sims and Morey, 1972 , p. 450); regardless of whether the rhyolite is intrusive or extrusive, this date suggests a minimum age for the formation.
The Sioux and Barron Quartzites are approximately correlative with the Sibley Group north of the Lake Superior syncline in Ontario, which lies stratigraphically between the Animikie and the Keweenawan. All three units formed after the Penokean orogeny, but before the accumulation of the Keweenawan Supergroup, during early Precambrian Y.

Farther south, in the Baraboo area of central Wisconsin, Precambrian rocks project through the surrounding lower Paleozoic strata in a partly exhumed monadnock, and have long been classic for student work because of their proximity to many Middlewestern universities. (My own first field experience was at Baraboo during a summer field course of the State University of Iowa.) The rocks of the sequence at Baraboo much resemble those of the lower part of the Marquette Range Supergroup (Precambrian X) in the Lake Superior Region to the north-a thick lower quartzite, followed by slate, iron formation, and dolomite-and were called "Huronian" in the older reports. Nevertheless, these rocks overlie felsic volcanics with rubidium-strontium age of about 1,600 m.y. (Dalziel and Dott, 1970, p. 8-10), so that they are younger than those with which they have been compared. Evidently they formed during the early part of Precambrian Y, like the Sioux and Barron Quartzites.

\section{PRECAMBRIAN Z}

Near the axis of the Lake Superior syncline, between the main body of the Keweenawan and the overlapping Upper Cambrian, is another body of sandstones, known as the Jacobsville in Michigan, the Bayfield in Wisconsin, and the Fon du Lac and Hinckley in Minnesota. At one time or another, geologists have assigned these sandstones to the Keweenawan or to the Cambrian, but they are unconformable with both and are probably part of neither.

Observed sequences of the sandstones are as much as $5,000 \mathrm{ft}(1,500 \mathrm{~m})$ thick, and geophysical surveys suggest that they may be $7,000 \mathrm{ft}(2,100 \mathrm{~m})$ thick on the southeast side of the Keweenaw Peninsula. They are red sediments like the underlying Keweenawan, but they are more cleanly washed, being quartzites rather than arkoses, with a less varied heavy mineral assemblage. Their sediment transport was again toward the axis of the Lake Superior syncline (whereas that of the Cambrian is mainly southward) (Hamblin, 1961, p. 6-13), so that subsidence of the trough continued, but dips of the sandstones are much lower than those of the Keweenawan.

These sandstones are probably the representatives of Precambrian Z in the Lake Superior Region, and they are so indicated on the Geologic Map, although definite radiometric proof is not available. 


\section{ADIRONDACK AREA}

The Adirondack area of Precambrian rocks of northern New York State is a domical uplift $120 \mathrm{mi}(195 \mathrm{~km})$ across, nearly encircled by Paleozoic rocks, but connected northwestward along the Frontenac axis with the Grenville province of the Canadian Shield, of which it is an extension. The Precambrian area includes two contrasting parts: a northwestern lowland $40 \mathrm{mi}$ $(65 \mathrm{~km})$ broad, dominantly of medium-grade metasedimentary rocks, and the Adirondack Mountains to the southeast of high-grade gneisses and extensive plutonic rocks; the two parts are juxtaposed along the Highland Boundary fault, downthrown toward the lowlands.

The Grenville Group of the lowlands (Y) is a metasedimentary sequence about $15,000 \mathrm{ft}(4,500 \mathrm{~m})$ thick (Engel and Engel, 1954, p. 1018), more than half of which is calcite or dolomite marble, and the remainder quartz-feldspar gneiss and minor quartzite. The rocks have been plastically folded and refolded, and metamorphosed to amphibolite grade (with sillimanite). They contain many concordant lenses and pods of hornblende granite ( $\mathrm{Yg} 2$ ), now with phacolithic structure but probably intruded before or during the folding (Buddington, 1939, p. 152-158).

The rocks of the mountains are a complex of paragneiss (Ym), orthogneiss (Ygn), syenite (Ys), and anorthosite (Ya), metamorphosed to granulite facies, probably at a deep level in the crust. The most prominent component is the anorthosite, covering 14 percent of the area and forming mountainous massifs, the largest of which is the Mount Marcy body $50 \mathrm{mi}(80 \mathrm{~km})$ across. The syenite (mangerite), in smaller areas, may be genetically related. The orthogneisses include both granitic and charnockitic varieties. The paragneisses were the host rocks of the others and have been correlated with the Grenville Group to the northwest, although they contain less marble.

The origin and sequence of the plutonic rocks has long been debated, and many views have been expressed. Buddington (1939, p. 197-235) believed that they were introduced as magmas, the anorthosite, syenite, and charnockite successively before the deformation, the granite during the major orogeny and metamorphism. At the opposite end of the spectrum is a proposal that all the plutonic components were remobilized from a deeper level, or basement, the mobilities ranging from slight in the anorthosite to a maximum in the granite; the more mobile the component the more transgressive the rock, hence the younger its apparent age (Walton and de Waard, 1963).

The Adirondack Precambrian rocks, like those of the rest of the Grenville province, yield characteristic
Grenvillian radiometric dates of 1,000-1,200 m.y., and large parts of them in the province have been called Grenville Series in a broad sense. ${ }^{7}$ The Geologic Map follows present Canadian usage (Emslie, 1970, p. 124 125) in restricting the Grenville Group to the recognizable metasedimentary rocks of the original Grenville area in southern Quebec and Ontario and the adjacent lowland of New York State. Igneous and metamorphic events in the lowlands have ages of 1,160-1,200 m.y. (Silver, 1963); structural evidence in Canada suggests that the group itself is Paleohelikian (=early Precambrian Y) (Emslie, 1970, p. 125). The other Precambrian rocks of the Adirondack area are likewise classed on the map as Precambrian Y, but not as Grenville.

The Adirondack anorthosite contains zircons which have been dated between 1,020 and 1,100 m.y. by uranium-lead methods; similar ages, but none older, have been found in the associated orthogneisses and pegmatites (Silver, 1968, p. 250). These dates record the time of granulite metamorphism, but it is claimed from the characteristics of the zircons that this is the age of the magmatic crystallization as well.

Nevertheless, the Adirondack anorthosites are part of a chain of massifs that extends $1,000 \mathrm{mi}(1,600 \mathrm{~km})$ north-northeastward, diagonally across the Grenville province, into the Nain province of eastern Labrador. Those of the latter province, outside the region of Grenvillian influence, yield Elsonian ages of about 1,400 m.y., and it has been suggested that the other massifs, many with apparently younger dates, have been reworked during the Grenvillian event (Stockwell, 1964, p. 3). Be that as it may, emplacement of the anorthosite massifs appears to have been a unique event in earth history; all known massifs, both in eastern North America and elsewhere, are datable within a span of a few hundred million years of middle Precambrian time, as we shall see when considering the anorthosite bodies farther west in the United States (p.50, 66). All are shown on the Geologic Map as Ya.

\section{NORTHERN APPALACHIAN REGION}

\section{PRECAMBRIAN Y OF WESTERN PART}

To the southeast and south of the Adirondack area, in the western part of the Northern Appalachians, Precambrian rocks with Grenvillian ages emerge in the higher uplifts, where they have been reworked during the various Paleozoic orogenies. They form

${ }^{7}$ The name "Grenville" has been extended from the original rocks of the Grenville Group to include a more comprehensive Grenville Series, a province and its northwestern tectonic front, and an orogeny. These extensions have been condemned by Gilluly (1966, p. 104-108), but in the absence of any acceptable substitute, common usage must prevail—provided care is taken by the geological author to specify clearly which of the several "Grenvilles" he is referring to. 
the basement of the Green Mountains of Vermont, the Berkshire Hills of Massachusetts, the Hudson Highlands of New York State, and the Reading Prong of New Jersey and Pennsylvania. The uplifts are links in a chain that extends from the Long Range in Newfoundland to the south end of the Blue Ridge in Georgia. The basement is overlain by Lower
Cambrian and younger Paleozoic geosynclinal rocks-basal miogeosynclinal quartzites on the west ( $€ q$, Cheshire and Poughquag), and more varied eugeosynclinal clastics and volcanics on the east (€e).

The uplifts are vergent westward or northwestward, and become increasingly allochthonous south-

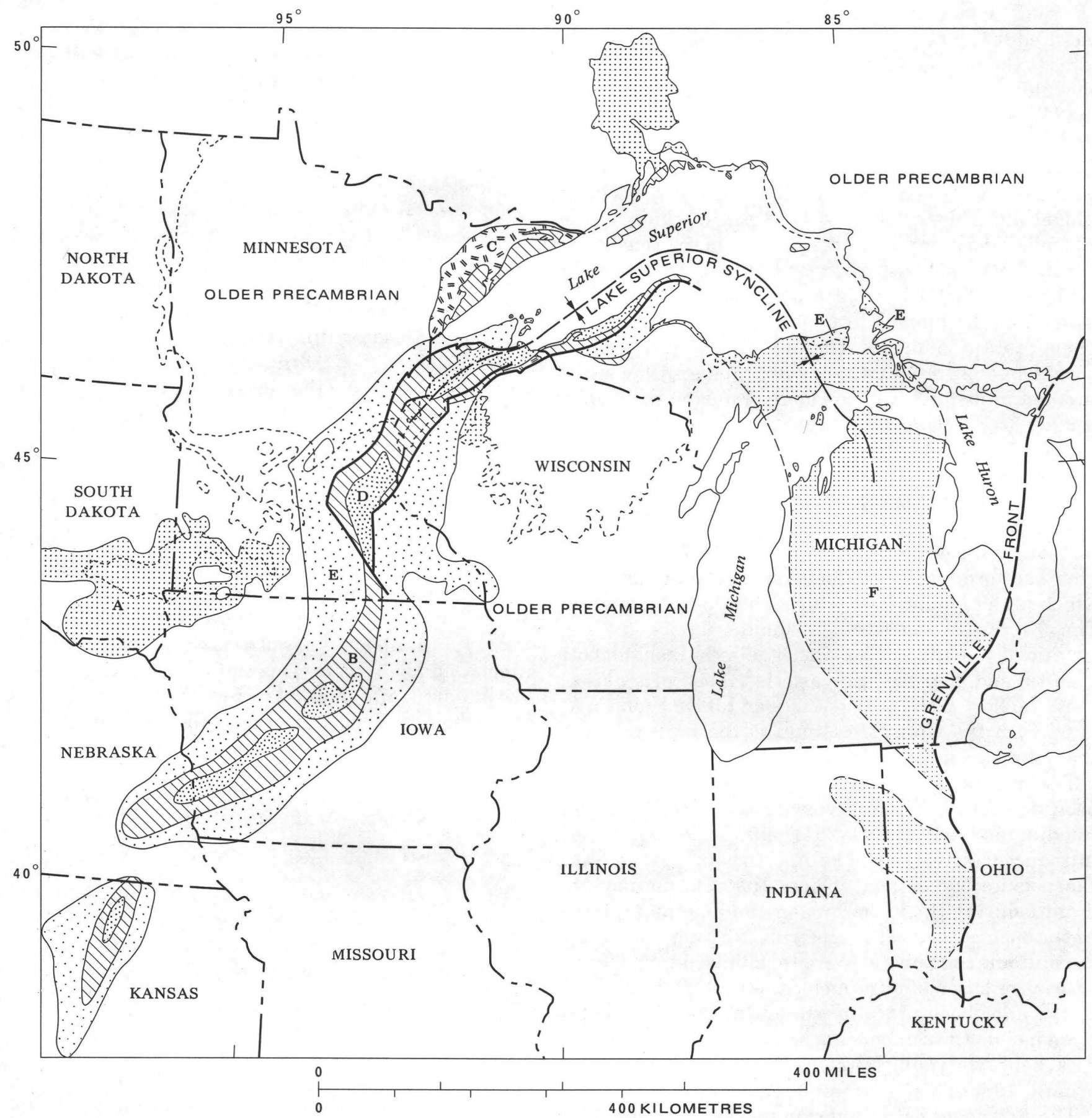

Figure 8.-Map of north-central United States, showing the arcuate pattern of surface and subsurface upper Precambrian rocks (Y and Z). (Based mainly on Craddock, in Sims and Morey, 1972, p. 283.) 
ward. The Green Mountains and Berkshire Hills are anticlinoria, the first with a steep west flank, the second overthrust westward. The Hudson Highlands and Reading Prong have commonly been interpreted as fault-bounded horsts, but modern work indicates that the Precambrian of the Reading Prong, at least, is part of a floored nappe with roots farther southeast (Drake, 1970, p. 286-289). The smaller Precambrian bodies east and southeast of the main chain of uplifts are even more complexly involved in the Appalachian deformations. Those in the cores of the Chester and Athens domes in the Connecticut Valley of southeastern Vermont have risen diapirically into a thick pile of eugeosynclinal strata. Those south of the Hudson Highlands (Fordham and Yonkers Gneisses) have been plasticly folded and refolded with the lower Paleozoic rocks of the New York City Group (Hall, 1968, p. 124).

The Precambrian rocks are dominantly paragneisses,

\section{EXPLANATION}

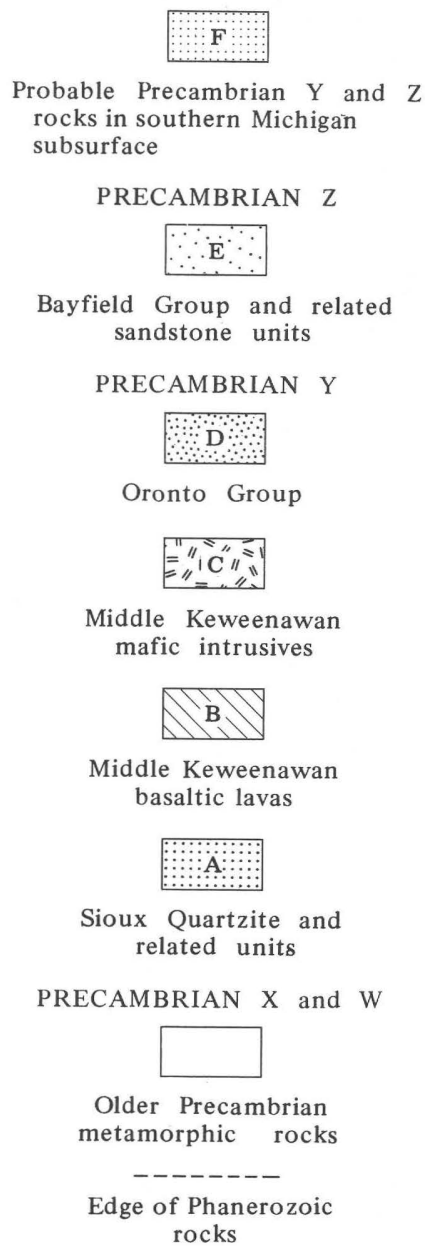

Figure 8.-Continued. with interbedded quartzite and marble units and minor intrusive orthogneisses. Many details of the subdivision and pattern of the gneisses are shown on the modern State Maps on a scale of 1:250,000, but this is impractical on the much smaller scale of the Geologic Map of the United States, where they are indicated merely as paragneiss (Ym). The pattern of the units in the Green Mountains uplift, as shown on the Vermont Map (fig. 9), is discordant to its elongation and crosses it nearly at right angles, although somewhat curved as a result of the Paleozoic uplift. The rocks underwent a Precambrian metamorphism to high amphibolite grade in the Green Mountains and granulite grade in the Reading Prong, but they were metamorphosed again and retrograded during the Appalachian orogenies.

As would be expected, the radiometric data reflect this complex metamorphic history. Relict Grenvillian dates of 900-1,100 m.y. have been obtained from the Green Mountains and Hudson Highlands by uranium-lead and related methods (Tilton and others, 1960, p. 4175; Faul and others, 1963, p. 3, 7). Determinations by rubidium-strontium and potassium-argon methods on rocks in the uplifts and southeastward yield mainly ages of about 360 m.y. that express the time of Paleozoic metamorphism, but there is a scatter of intermediate dates that express either genuine events, or a resetting of original Grenvillian ages by the later metamorphism (Long and Kulp, 1962, p. 984-987).

\section{PRECAMBRIAN Z OF EASTERN PART}

None of the Precambrian Y basement is found east of the Connecticut Valley, but younger Precambrian is mapped in widely separated areas in eastern New England. In western Maine the oldest rocks of the Boundary Mountains anticlinorium form the Chain Lakes massif, and are largely highly metamorphosed paragneiss, quartzite, and amphibolite. They are certainly pre-Ordovician and might be Cambrian, but a Precambrian? age has been suggested for them (Boone and others, 1970, p. 11); on the Geologic Map they are indicated as $\mathrm{Z}$ with a metamorphic overprint. Farther southeast in Maine, near Islesboro on an island in Penobscot Bay, metamorphic rocks in a small horst have yielded a 900 m.y. date by rubidium-strontium methods and are cut by 600 m.y.-old pegmatites (Stewart, 1974, p. 89-90); they are likewise mapped as Precambrian Z.

In Rhode Island and southeastern Massachusetts, adjoining the Pennsylvanian Narragansett basin, is a much larger area of late Precambrian rocks. It includes on the east the Dedham Granodiorite and on 


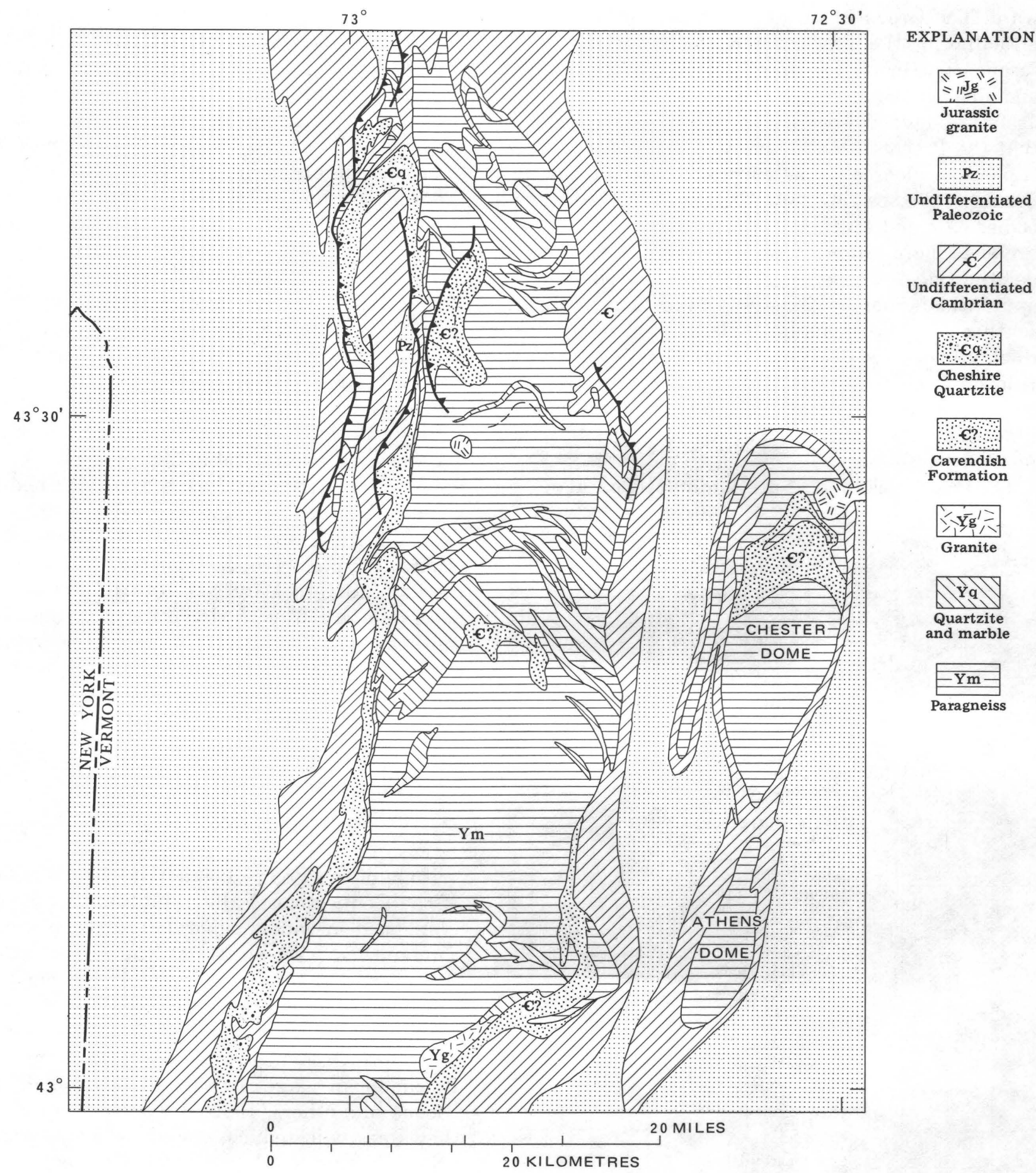

Figure 9.-Map showing part of the Green Mountain uplift in south-central Vermont, and the Athens and Chester domes east of it, showing superposition of north-south Paleozoic (= Appalachian) trends on east-west Precambrian trends (mainly Grenvillian). Generalized from Geologic Map of Vermont (1961).

the west various granitic orthogneisses (Milford, Northbridge, Scituate, etc.). A key locality for stratigraphic relations is Hoppin Hill, Mass., near the northeastern corner of Rhode Island, where fossiliferous Lower Cambrian strata lie on the eroded surface of granodiorite (Dowse, 1950); however, the old rocks of the hill are separated from the rest by
Pennsylvanian cover. Radiometric determinations by the rubidium-strontium method on the Dedham Granodiorite and Northbridge Gneiss yield ages of 591 and 569 m.y. respectively; the granodiorite at Hoppin Hill yields an age of 514 m.y. but this may have been downgraded during the pre-Paleozoic weathering. The true age of all the granitic rocks in the area may be near 
570 m.y. (Fairbairn and others, 1967, p. 324); they are represented on the Geologic Map as Zg.

Large enclaves in the orthogneisses west of the Narragansett basin are an earlier supracrustal sequence, the Blackstone Series which is $15,000 \mathrm{ft}(4,500 \mathrm{~m})$ or more of schist, quartzite, and greenstone (Quinn, 1971, p. 8-14); like the plutonic rocks, the supracrustal rocks are included in Precambrian Z.

\section{THE AVALONIAN BELT}

The Precambrian rocks of southeastern New England are an extension of those of the Avalonian belt (= Avalon platform) of the Appalachian province in Canada-a domain of late Precambrian (Z) supracrustal and magmatic rocks and events different from those farther northwest-typified in the Avalon Peninsula of southeastern Newfoundland, but represented also in Cape Breton Island and southeastern New Brunswick (Poole and others, 1970, p. 231-235; Rodgers, 1972, p. 512-514). In Newfoundland the belt includes basal volcanics intruded by the Holyrood Granite, followed by a thick sequence of clastic deposits, the whole overlain unconformably by the Lower Cambrian; the granite has been dated at 575 m.y. (later recalculated at 610 m.y.). An "Avalonian orogeny" has been postulated between the granite and volcanics and the succeeding clastic deposits (Poole and others, 1970, p. 232-233), but relations have been plausibly reinterpreted as a product of volcanic and depositional events, punctuated by local disturbances, that do not express an "orogeny" in the usual sense (Hughes, 1970; Hughes and Brückner, 1971).

Nevertheless, the term "Avalonian" is appealing and is widely used, in the same manner as the term "Grenvillian" discussed earlier (footnote 7). It can appropriately be applied to a terrane of wellcharacterized rocks and structures of late Precambrian and early Paleozoic age in eastern Canada and the United States, whether or not this involves a narrowly defined "Avalonian orogeny." In the northwestern part of the Appalachian region, Lower Cambrian strata with an Olenellus fauna lie on a 1,100-m.y.-old Grenvillian basement. By contrast, in the Avalonian belt to the southeast, Lower Cambrian strata with a Paradoxides fauna lie on a 600-m.y.-old Avalonian basement (Wilson, 1969, p. 282). The Cambrian of the Avalonian belt is much more akin to the Cambrian of the southern British Isles and western Europe than to the Cambrian of the remainder of North America (Palmer, 1967, p. 143-144), suggesting that the belt may be an extension of its trans-Atlantic counterparts which was joined to North America by plate collision during Paleozoic time.

South of New England the Avalonian belt seem- ingly extends into the metamorphic rocks of the Piedmont province and their buried extensions beneath the Atlantic Coastal Plain (p. 39).

\section{CENTRAL AND SOUTHERN APPALACHIAN REGION ${ }^{8}$}

In the Central and Southern Appalachians, the principal occurrence of identifiable Precambrian rocks is in the Blue Ridge province, a mountainous belt that lies between the Valley and Ridge province and the Piedmont province from southern Pennsylvania to northern Georgia. No Precambrian rocks are exposed in the Valley and Ridge province, but dated Precambrian emerges in some of the higher uplifts of the Piedmont province, and Precambrian is probably also included in the undeciphered metamorphic complex $(m)$ of the inner Piedmont and the less-metamorphosed strata of the Carolina Slate Belt.

Compared to the Canadian Shield, all the Precambrian of the Central and Southern Appalachians is rather young. Even its crystalline basement yields dates no earlier than Grenvillian, and is accordingly classed as Precambrian Y. The great body of supracrustal rocks above it is therefore Precambrian $\mathrm{Z}$, and is, in fact, the greatest development of this division in the United States, even exceeding that in the western Cordillera (fig. 5).

In the Central and Southern Appalachians, as in the Northern, the Precambrian is heavily involved in the Paleozoic orogenies. The basement, which underwent deformation during the Grenvillian event, was reworked and its metamorphic fabric retrograded. By contrast, the Precambrian supracrustal rocks were not significantly deformed during Precambrian time, and owe all their present structural and metamorphic complexities to deformations during the Paleozoic.

\section{BLUE RIDGE BELT}

The northern segment of the Blue Ridge is an anticlinorium, vergent westward, about $15 \mathrm{mi}$ (25 $\mathrm{km}$ ) broad near the Potomac River, but widening southward. In central Virginia low-angle thrusts appear along its northwestern border, and the belt becomes increasingly allochthonous. The extent of transport on the thrusts in the Tennessee-North Carolina segment is suggested by windows southeast of their leading edges, notably the Grandfather Mountain window on the southeastern side of the belt. From North Carolina to the edge of the Coastal Plain in Alabama the southeastern tectonic boundary of the Blue Ridge belt is the Brevard zone of highangle faults.

The Precambrian of the Blue Ridge is overlain by Paleozoic geosynclinal deposits, the belt marking the

${ }^{8}$ For details available through 1966 , see King (1970, p. 17-54); the present account in cludes later observations and revisions 
approximate boundary between their miogeosynclinal and eugeosynclinal parts. Along the northwestern flank the basal miogeosynclinal deposits are the Lower Cambrian quartzites and clastics of the Chilhowee Group ( $€ q)$, whose mature sediments contrast with the immature sediments of the Precambrian supracrustal sequence (Z). In places the Chilhowee transgresses across them onto the basement (Y), perhaps because this flank of the Blue Ridge was near the original northwestern limit of the Precambrian supracrustal rocks. The contrast fades on the southeastern flank of the Blue Ridge, where the Precambrian supracrustal rocks and the Paleozoic eugeosynclinal rocks $(€$ e) are more alike and more accordant (fig. 10).

\section{PRECAMBRIAN Y}

In the Maryland-Virginia segment of the Blue Ridge the basement of the anticlinorium is a plutonic complex (Ygn) of granodioritic and granitic orthogneisses and migmatites, with one small body of anorthosite (Ya). Traces of earlier host rocks of undetermined age occur in places, nearly destroyed by granitization. All the complex is hypersthene-bearing and charnockitic, and underwent metamorphism to granulite grade during the Grenvillian event. The plutonic basement extends southwestward into the Tennessee-North Carolina segment to form the Cranberry, Max Patch, and similar gneisses.

Radiometric determinations on rocks of the complex in northern Virginia yield dates by uraniumlead and related methods of 1,070-1,150 m.y., and by rubidium-strontium and potassium-argon methods of 880 and 800 m.y., respectively; similar results have been obtained in the Tennessee-North Carolina segment (Tilton and others, 1960, p. 4175-4176). In the latter segment rubidium-strontium whole-rock determinations on many of the basement units yield ages between 1,025 and 1,250 m.y. (Fullagar and Odom, 1973, p. 3076-3077); it is suggested that the basement is a 1,200-1,300-m.y.-old crust that was remobilized during the Grenvillian event 1,050 m.y. ago, without the addition of new material.

Distinctions between the basement and its cover become blurred farther southwest, in the border region of North Carolina and Georgia (fig. 7). The rocks have passed into the high amphibolite (sillimanite) phase of Paleozoic metamorphism (Hadley and Nelson, 1971), and are thrown into large-scale recumbent folds or nappes (Hatcher, 1971, p. 41-42; 1973, p. 683). On the Geologic Map, considerable areas are shown as Precambrian Y (paragneiss and schist, Ym), based on the best information available in 1971, but this will require revision on the basis of later work, in part still in progress (for example,
Hatcher, 1973.) Much of the Ym unit on the map is biotite gneiss and interbedded amphibolite, which is probably a lower unit of Precambrian Z. True basement is probably represented by the Whiteside Granite and related rocks, but even these are in the cores of nappes, and rootless in part.

On the northwest edge of the Blue Ridge belt near Cartersville, Georgia, the Corbin Granite (gneiss) has sometimes been interpreted as a Paleozoic intrusive, but uranium-lead determinations on zircons show that it has an age of 1,100 m.y. (Odom and others, 1973); it and probably the adjacent Salem Church Granite are therefore basement to the surrounding Precambrian Z Ocoee Supergroup. Farther southwest, near the edge of the Coastal Plain in Alabama is the Kowaliga Gneiss (= "biotite augen gneiss" of the Alabama State Map of 1926), which was proposed as basement rock (Bentley and Neathery, 1970, p. 19-20) and is so represented on the Geologic Map; however, radiometric determinations yield ages no greater than $550 \mathrm{~m} . \mathrm{y}$., so this assignment is suspect.

\section{PRECAMBRIAN Z}

The supracrustal rocks of the Blue Ridge belt lie unconformably on the deeply eroded surface of the basement-the greatest structural break in all the Appalachian stratified sequence below the base of the Triassic. Although this relation is fundamental to the Precambrian geology of the region, it was curiously misapprehended for a long period; in the northern Blue Ridge the plutonic rocks were thought to intrude the supracrustal rocks, and were so represented on the Geologic Map of the United States of 1932. It was not until much later that Jonas and Stose (1939) deduced the true relation, a deduction abundantly confirmed by subsequent investigations.

The supracrustal rocks are an extensive and varied suite, broadly of the same age, although not all their mutual relations have been determined with certainty. Volcanic rocks are common in the northwest and north, but most of the remainder are immature clastic sedimentary rocks.

In Maryland and northern Virginia, the dominant supracrustal unit on the northwestern flank of the Blue Ridge is the Catoctin Greenstone ( $\mathrm{Zv})$, a body of mafic lava as much as $5,000 \mathrm{ft}(1,500 \mathrm{~m})$ thick, originally basaltic, into which felsic lavas interfinger northward. The mafic lavas were spread out in flows several hundred feet thick, under terrestrial conditions; many of them are amygdaloidal and some of them contain well-preserved columnar jointing (Reed, 1969 , p. 21-32). Between the lavas and the eroded surface of the basement is commonly a thin sedimentary layer (Swift Run Formation) (fig. 10). 


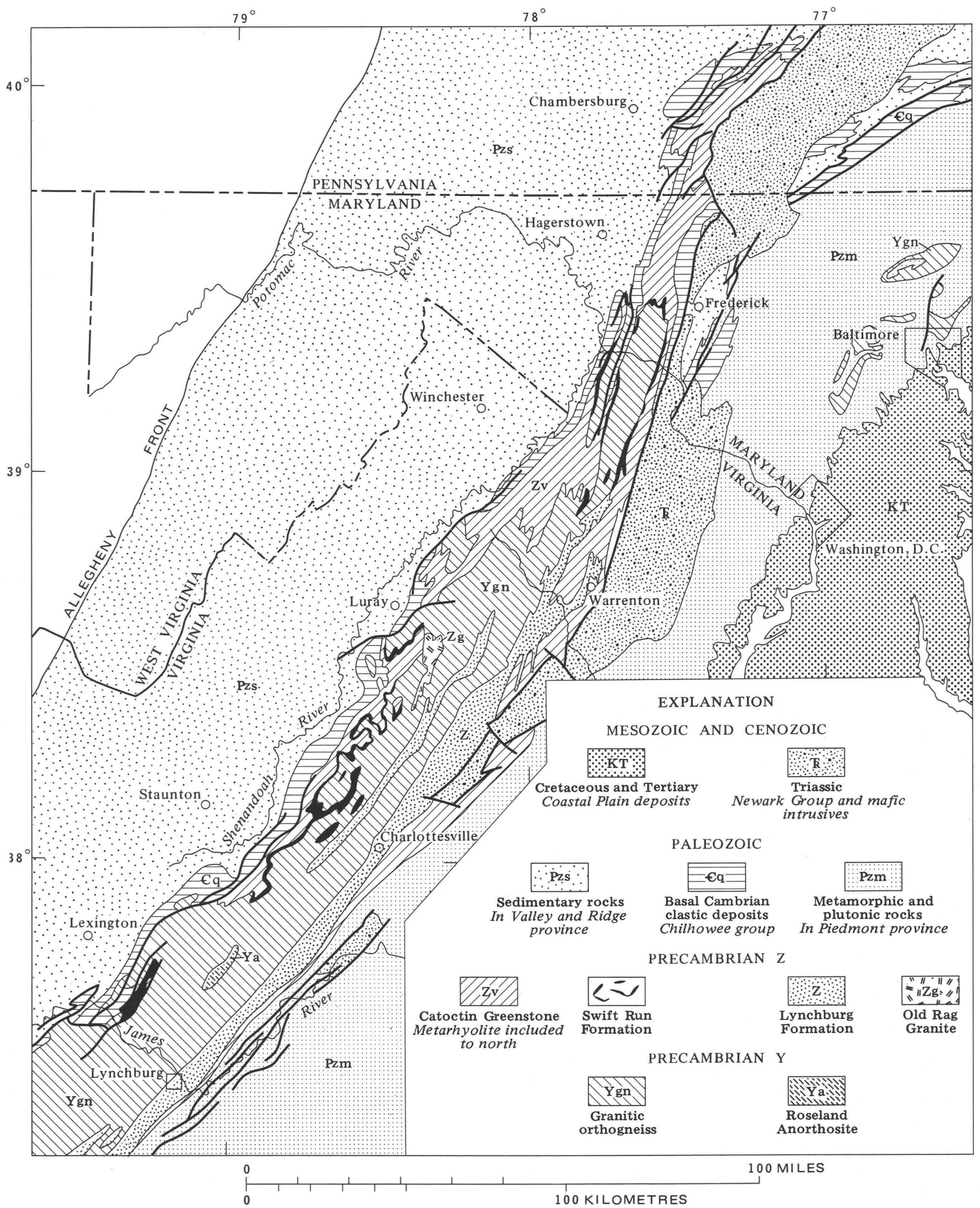

Figure 10.-Map of northern part of Blue Ridge uplift in Virginia, Maryland, and Pennsylvania, showing relations of Precambrian $\mathrm{Z}$ rocks to underlying Precambrian Y basement, and to adjacent Phanerozoic rocks. Compiled from state geologic maps, and other sources. 
Across the anticlinorium to the southeast, the lower sedimentary unit expands into the Lynchburg Formation (Z), a mass of medium- to coarse-grained turbidites at least $10,000 \mathrm{ft}(3,000 \mathrm{~m})$ thick, with lenses of bouldery conglomerate in the lower part derived from the plutonic basement (Rockfish Member). The Catoctin lavas thin out above the Lynchburg, but are the principal marker for separating it from the similar and apparently conformable Cambrian eugeosynclinal deposits (€e, Evington Group) (fig. 11). Relations on the southeastern flank of the anticlinorium are obscured by the higher grade of Paleozoic metamorphism (amphibolite grade) and many of the rocks are schistose or gneissic.

Farther southwest in the Blue Ridge, near the Virginia-North Carolina boundary, volcanic rocks are again prominent on the northwestern flank (fig. 12). Thick bodies of rhyolite form the middle part of the Mount Rogers Formation, and both rhyolite and basalt occur in the Grandfather Mountain Formation (in the Grandfather Mountain window, hence also of northwestern facies). Congeneric with the volcanics is the Crossnore Plutonic Group, which includes many moderate-sized granitic plutons $(\mathrm{Zg})$ that are embedded in the adjacent basement rocks. These southwestern volcanics are associated with greater volumes of clastic sediments than are those of the Catoctin. The upper sedimentary unit of the Mount Rogers Formation includes red, rhythmically bedded siltstone, and coarse diamictite formed of boulders of the basement plutonics, very much like the late Precambrian diamictites in several parts of the Cordillera to which have been ascribed a glacial origin (Rankin, 1970, p. 232).

On the southeastern flank of the Blue Ridge, the broad band of metasedimentary supracrustal rocks continues from the Lynchburg area through southern Virginia into North Carolina. In the latter segment it is the Ashe Formation (Rankin, 1970, p. 232-233), a thick mass of fine- to medium-grained biotitemuscovite gneiss; with interbedded amphibolite $(\mathrm{Zv})$, especially in the lower part, that originated from mafic volcanic rocks. In the Spruce Pine pegmatite district, North Carolina, west of the Grandfather Mountain window, the Ashe lies in a southwestplunging synclinorium, in the keel of which, on the heights of Mount Mitchell, it is overlain by rocks lithically like the Great Smoky Group of the Ocoee Supergroup (Hadley, 1970, p. 249).

The Ocoee Supergroup (Z) dominates the southwestern segment of the Blue Ridge belt, extending along its strike for more than $175 \mathrm{mi}(280 \mathrm{~km})$, from Asheville, North Carolina, to Cartersville, Georgia, and across it for $40 \mathrm{mi}(65 \mathrm{~km})$ or more; it projects in high ranges, such as the Great Smoky Mountains (King and others, 1968, p. 3-9) (fig. 13). The Ocoee is a great mass of nonvolcanic clastic sedimentary rocks; partial sequences as much as $25,000 \mathrm{ft}(7,600$ m) thick have been observed but the total is undetermined. Along its southeastern side the Ocoee lies unconformably on the basement orthogneisses and paragneisses (Ygn, Ym); on its northwestern side it is succeeded disconformably by the Chilhowee Group (€q); also, a belt of synclinally infolded younger rocks near its center (1D) includes the Murphy Marble that contains sparse lower Paleozoic fossils (McLaughlin and Hathaway, 1973).

The Ocoee has been divided into the contrasting Walden Creek, Snowbird, and Great Smoky Groups (not differentiated on the Geologic Map but shown in fig. 13), which evidently formed in different parts of the original sedimentary basin, but they have been so telescoped by Paleozoic thrusting that most of their original relations to each other are now lost. In places one of the groups can be found in sequence with another, but it is likely that all of them were extensively intergradational. The varied clastics of the Walden Creek probably formed on an unstable shelf along the northwestern margin of the basin; the Snowbird is an intermediate facies; and the Great Smoky is a deepwater continental rise deposit. Much of the Great Smoky is a medium- to coarse-grained quartz-feldspar turbidite with prominent graded bedding, with which thin to thick units of dark sulfidic argillaceous rocks are interbedded.

South of the main Ocoee area, along the southeastern edge of the Blue Ridge belt, strips of paraschist and paragneiss altered from rocks like the Great Smoky extend to the Coastal Plain border in Alabama, where they are the Heard Group of Bentley and Neathery (1970, p. 14-18). Associated with them, and mainly underlying them, are biotite gneisses and interbedded amphibolites, sometimes called Precambrian Y basement (p. 31), but more likely comparable to the volcanic rocks in the lower part of the Ashe Formation farther northeast.

An exceptional feature in northeastern Georgia is the Tallulah Falls dome, exposing a quartzite formed of nearly pure siliceous sand; following a suggestion of Burchfiel and Livingston (1967, p. 252) we have speculatively correlated it on the Geologic Map with the Lower Cambrian Chilhowee Group (€q). However, Hatcher $(1973$, p. 683$)$ interprets the dome as a culmination in a much broader recumbent nappe, and considers the quartzite to be a unit near the middle of the Precambrian $\mathrm{Z}$ sequence.

Although the general position of the Precambrian $\mathrm{Z}$ supracrustal rocks of the Central and Southern 


\section{NORTHWEST}

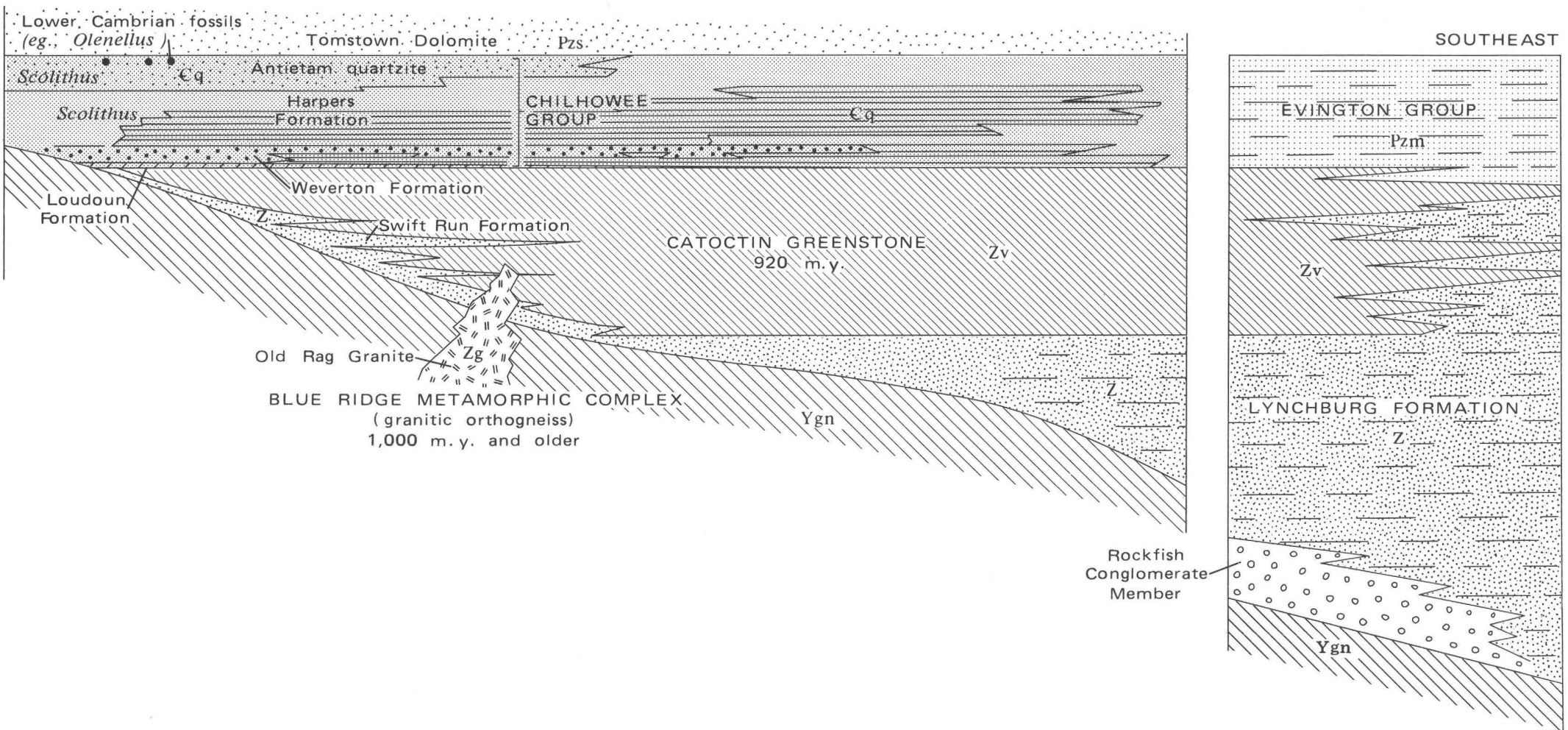

FIGURE 11.-Stratigraphic diagram extending transversely across the Blue Ridge uplift in northern Virginia, showing relation of units of Precambrian $\mathbf{Z}$ and Cambrian. Letter symbols are the same as those in figure 10. Based on Bloomer and Werner (1955, p. 588), but with many modifications. 


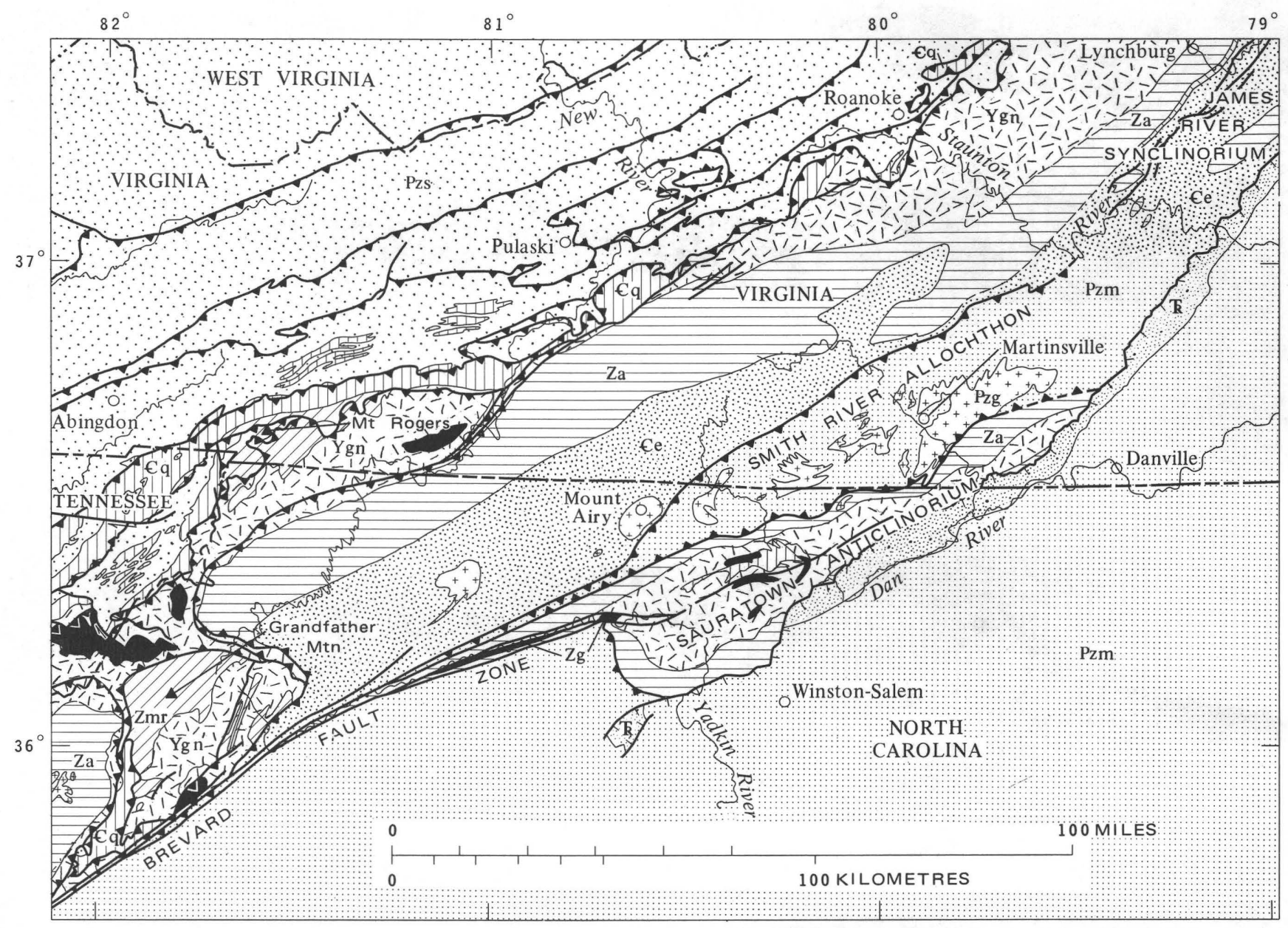

$\begin{array}{lllllllllllllllllll}\text { E } & X & \text { P } & \text { L } & \text { A } & \text { N } & \text { A } & \text { T } & \text { I } & \text { O } & \text { N }\end{array}$
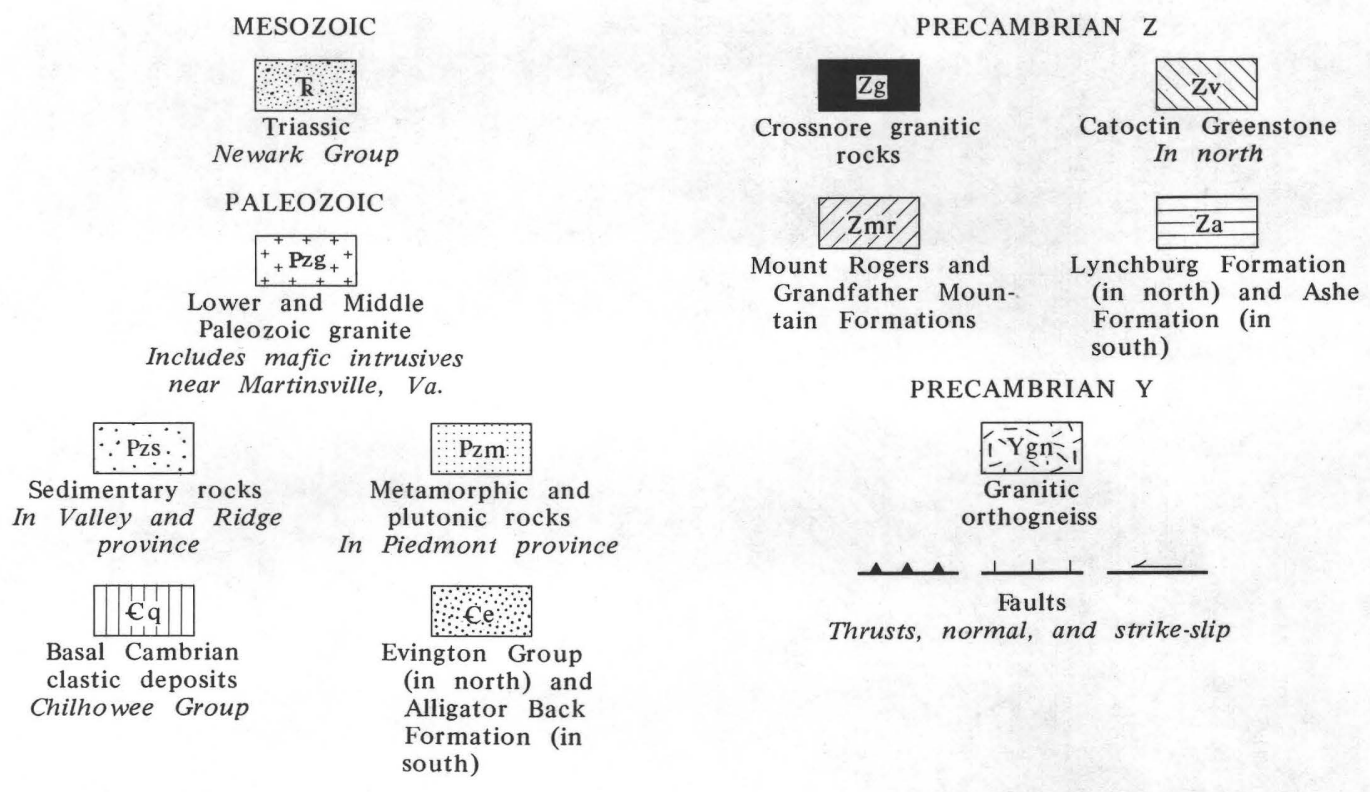

Figure 12.-Map of part of Blue Ridge uplift in the border region of Virginia, North Carolina, and Tennessee, showing Precambrian Y and Z, and Paleozoic units. Compiled from Rankin, Espenshade, and Shaw (1973, p. 6, 8), Conley and Henika (1973, p. 41, pl. 4), and other sources. 
Appalachians between their Precambrian Y (Grenvillian) basement and the Lower Cambrian is plain, the precise stratigraphic positions and ages of the different parts are as yet uncertain. The sediments of the Ocoee Supergroup, for example, contain detrital zircons with lead-alpha dates of 820-1,000 m.y. (Carroll and others, 1957 , p. 186-188), which express merely the age of the basement from which they were derived; other dates from the Ocoee are around 350 m.y. and record the age of their Paleozoic metamorphism (Kulp and Eckelmann, 1961, p. 410 413). Even fewer data are available for the other sedimentary components of Precambrian Z, such as the Lynchburg and Ashe Formations.

The most specific information on the age of the supracrustal sequence has been obtained from uranium-lead determinations on zircons from the felsic volcanic rocks, which indicate an original age of 820 m.y. and an episodic lead loss at 240 m.y. (the latter probably at the time of the Appalachian orogeny) (Rankin and others, 1969). Dated specimens were obtained from felsic volcanics associated with the Catoctin Greenstone in southern Pennsylvania, from the Mount Rogers Formation in Virginia, and from the Grandfather Mountain Formation in North Carolina. No determinations are possible by this method on the mafic volcanics, but by extrapolation the 820 m.y. age probably applies to the Catoctin Greenstone as well; as indicated earlier, the Catoctin overlies the sedimentary part of the supracrustal sequence (Swift Run and Lynchburg) in the northern Blue Ridge, and thus sets a terminal date for Precambrian $\mathrm{Z}$ in this segment. The similar ages from the Mount Rogers and Grandfather Mountain Formations farther southwest are less decisive, as their felsic volcanics lie farther down in the local sequences.

\section{PRECAMBRIAN OF PIEDMONT PROVINCE}

The extensive Piedmont province southeast of the Blue Ridge belt is a domain of crystalline rocks that were mobilized and subsequently consoldiated during the orogenies of Paleozoic time. In this respect it resembles the crystalline area of New England in the Northern Appalachians, but whereas the stratigraphic sequence in New England is now fairly well known, much of that in the Piedmont is still poorly understood. Representation of the Piedmont province on the Geologic Map was assembled from the best data available in 1971, but investigations are actively in progress which will modify this representation in many places.

Precambrian basement rocks, the Baltimore Gneiss (Ygn), form the cores of half a dozen mantled gneiss domes in eastern Maryland and adjacent Pennsylvania that have risen steeply into the supracrustal eugeosynclinal rocks of the Glenarm Series (€e). Radiometric determinations on zircons from the gneiss by uraniumlead and related methods yield ages of 1,000-1,100 m.y., whereas biotite from the gneiss yields rubidiumstrontium and potassium-argon ages of 300-400 m.y., expressing the time of Paleozoic metamorphism (Tilton and others, 1958).

At the northern edge of North Carolina, north of Winston-Salem (fig. 12), is the Sauratown anticlinorium, more than $50 \mathrm{mi}(80 \mathrm{~km})$ long and $15 \mathrm{mi}(25$ $\mathrm{km}$ ) broad, whose core exposes biotite gneiss and schist, and minor granitic gneiss, which are flanked by Precambrian $\mathrm{Z}$ Ashe Formation. The granitic rocks of the core have yielded an age of 1,192 m.y. by lead-lead determinations on zircons (Rankin and others, 1973, p. 19).

The only proved basement rocks farther southwest in the Piedmont province are the Woodland Gneiss and Jeff Davis Granite near Warm Springs, western Georgia, which have yielded uranium-lead ages of 1,000 m.y. (Odom and others, 1973; Sandrock and Penley, 1974). They lie beneath, but may intrude a metasedimentary sequence shown as $\mathrm{Z}$ and $\mathrm{lB}$ on the Geologic Map. All these are components of the Wacoochee belt which is bordered on both north and south by major faults, so that their relations to the adjacent Piedmont rocks on each side is undetermined.

Most of the country rock of the Piedmont province (aside from the abundant plutons) is shown on the Geologic Map as unclassified metamorphic complex (m) and as Cambrian eugeosynclinal deposits $(€ \mathrm{e}, € \mathrm{v})$. In North and South Carolina and adjacent States the eugeosynclinal deposits are the low-grade metamorphic sedimentary and volcanic rocks of the Carolina Slate Belt. The metamorphic complex, distinguished by its higher metamorphic grade, is partly equivalent, but may probably be partly older. The rocks of the Slate Belt are shown as Cambrian on the map mainly on the basis of the occurrence of Middle Cambrian Paradoxides in southern North Carolina, but the sequence evidently contains older components. Farther north, Lynn Glover III and his associates have found Ediacaran (= Vendian) type fossils at a locality on the Little River 12 miles north of Durham, N.C. They are the imprints of soft-bodied wormlike animals, preserved on bedding surfaces of the volcaniclastic strata. Comparable fossils occur in the Precambrian Z Conception Slate of the Avalon Peninsula, southeastern Newfoundland. At the north end of the Slate Belt in southern Virginia the Slate Belt rocks, the adjacent gneisses, and the associated intrusives have yielded an array of dates by uranium-lead methods ranging from 575 to 620 m.y., 
suggesting an event of supracrustal accumulation, magmatic activity, and mild deformation near or a little before the beginning of the Cambrian (= Virgilina deformation of Glover and Sinha, 1973, p. 247).

These features have little resemblance to the late Precambrian-Early Cambrian features to the northwest in the Blue Ridge province, but the precise limits of the two terranes are still uncertain. In part of North Carolina they are juxtaposed along the Brevard zone, but in other places, as noted above, Grenvillian base- ment and its supracrustal cover extends into the northwestern part of the Piedmont. Be that as it may, the late Precambrian-Early Cambrian rocks and events in the Piedmont most closely resemble those of the Avalonian belt farther northeast in the Appalachians (p. 33; Rodgers, 1972, p. 514-516). Like them, the Piedmont rocks may have formed in a realm far away from the northwestern belts of the Appalachians and were brought against them by plate collision during Paleozoic time (Odom and Fullagar, 1973, p. 140-146).

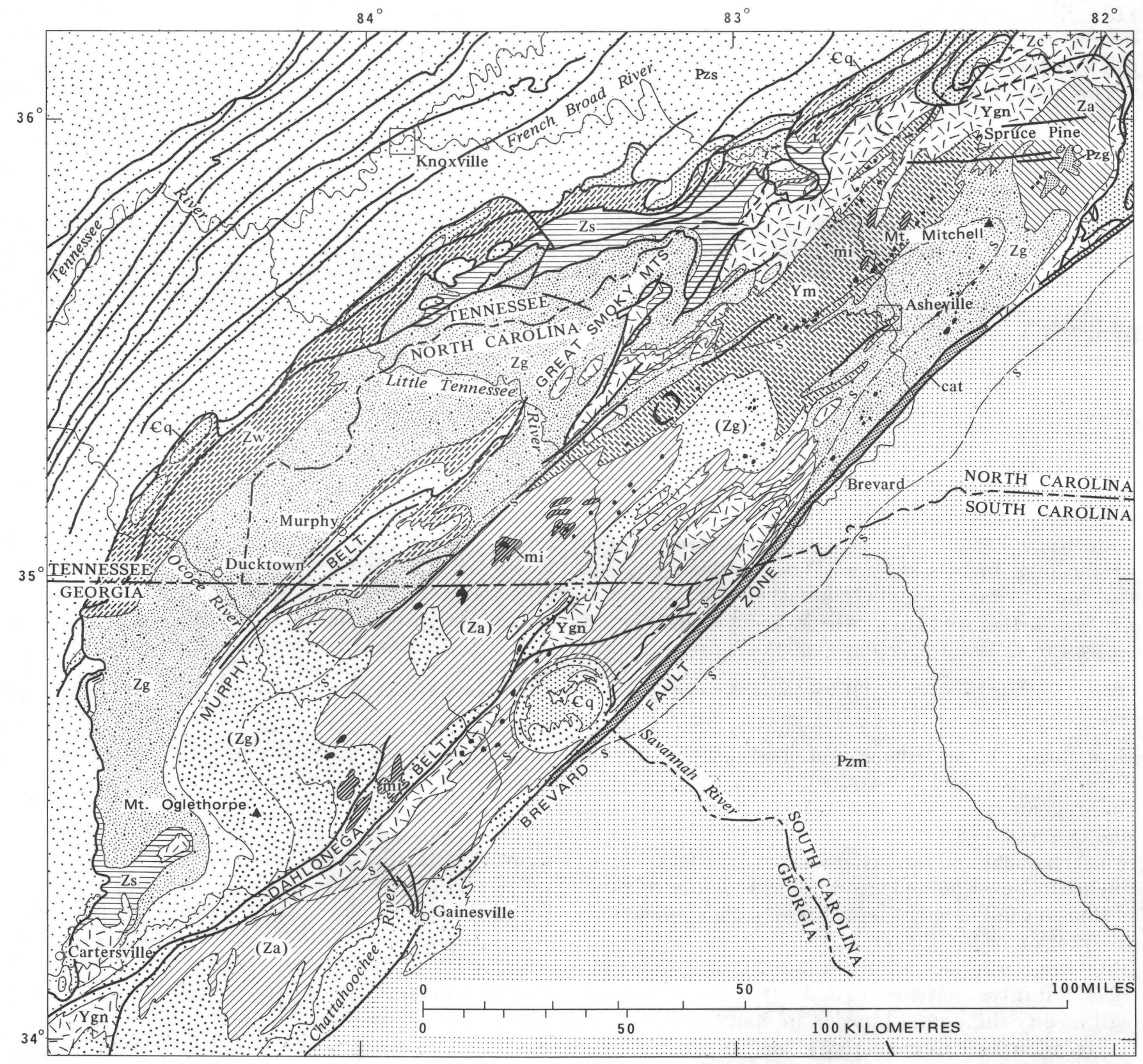

FIGURE 13.-Map of southwestern end of Blue Ridge belt in southern North Carolina and Tennessee, and northern Georgia, showing Ocoee Supergroup, its subdivisions, and related rocks of Precambrian Z, as well as their Precambrian Y basement. Compiled from State geologic maps, Hadley and Nelson (1971), Hurst (1973), Hatcher (1973), and other sources. 


\section{SOUTH-CENTRAL UNITED STATES ${ }^{9}$}

The wide Interior Region of the United States, between the Appalachian and Cordilleran orogenic belts, is a domain of little deformed Phanerozoic rocks a few hundred to many thousands of feet thick, through which their basement emerges only in small, widely separated areas. In the southern part of the region the principal basement exposures are in the Ozark uplift of Missouri, the Arbuckle and Wichita Mountain uplifts of southern Oklahoma, and the Llano uplift of central Texas.

${ }^{9}$ For a summary of information available through 1966 , see Flawn and Muehlberger (1970, p. 73-143); additional data on geochronology and subsurface relations are given by Muehlberger, Hedge, Denison, and Marvin (1966).

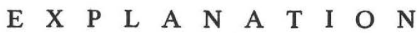

PALEOZOIC

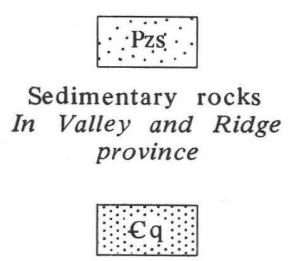

Basal Cambrian

clastic deposits

Chilhowee Group
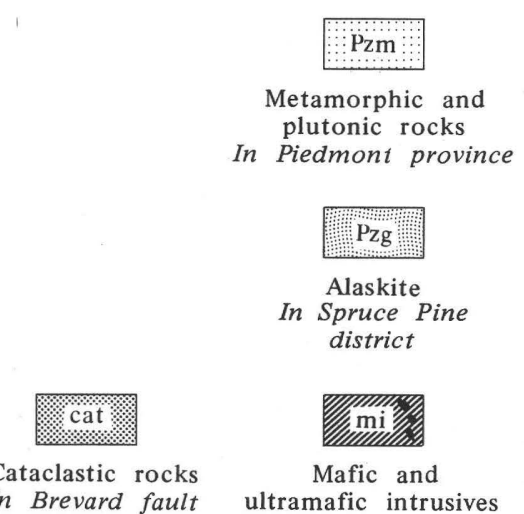

zone

PRECAMBRIAN $\mathrm{Z}$

OCOEE SUPERGROUP
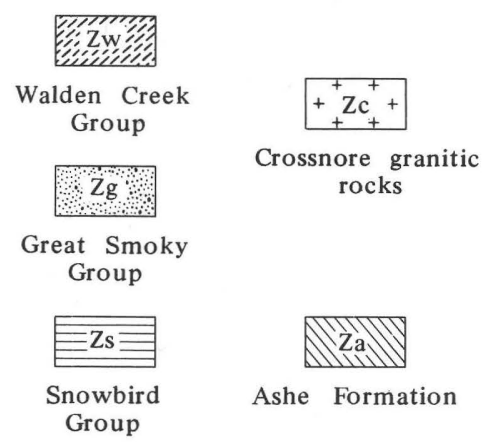

Ashe Formation

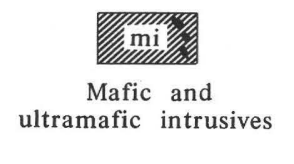

\section{.}


the eastern end. Westward, the basement of the horst is overlapped by Upper Cambrian; eastward, it passes beneath Cretaceous Coastal Plain deposits but continues in subsurface $45 \mathrm{mi}(72 \mathrm{~km})$ farther, to the front of the Ouachita orogenic belt. The principal unit is the coarse, porphyritic Tishomingo Granite, but there is also a finer grained Troy Granite, as well as minor younger diorites and dike rocks. Both the Tishomingo and Troy have yielded ages in the range of $1,320-1,400 \mathrm{~m} . \mathrm{y}$. by rubidium-strontium and other methods (Ham and others, 1964, p. 126-140).

The basement of the Wichita Mountains (and their largely buried extension to the east-southeast) is different and younger. It is a varied assemblage of floored felsic and mafic plutons embedded in supracrustal volcanics and sediments, all with ages of about 525 m.y., hence early Cambrian (Ham and others, 1964, p. 3537 ); because of their small surface extent they are grouped on the Geologic Map as $€ g$ (Cambrian granitic rocks). Basement of Wichita type extends into the Timbered Hills uplift at the west end of the Arbuckle Mountains.

\section{LLANO UPLIFT}

In central Texas, south of the Arbuckle-Wichita orogenic belt, Precambrian rocks are exposed in an area of $2,000 \mathrm{mi}^{2}\left(5,200 \mathrm{~km}^{2}\right)$ on the crest of the Llano uplift (fig. 14). The uplift is a structural high at the edge of the North American craton, little disturbed by Phanerozoic movements except for high-angle block faulting. Cambrian and younger Paleozoic rocks slope northward and westward away from the Precambrian into the craton, and all of them are overlapped by Cretaceous deposits that dip southeastward beneath the Gulf Coastal Plain. A short distance southeast of the edge of the Cretaceous overlap the rocks of the Llano uplift adjoin in subcrop the much more deformed Paleozoic rocks of the Ouachita orogenic belt.

The country rocks of the Precambrian basement are the felsic Valley Spring Gneiss and the mafic Packsaddle Schist (Ym), folded along northwest-trending axes and derived from an original supracrustal sequence no less than $20,000 \mathrm{ft}(6,000 \mathrm{~m})$ thick. In these are embedded granitic rocks ( $\mathrm{Yg} 2$ ), which form more than a third of the exposed area, as well as minor granite porphyry and pegmatite dikes, and a single ultramafic body (um). The granites were emplaced in three plutonic series, of which the youngest (Town Mountain) is the most extensive; it includes more than half a dozen nearly circular plutons $10 \mathrm{mi}(16 \mathrm{~km})$ or more across.

Efforts to obtain radiometric ages from the Llano Precambrian extend back three-quarters of a century to calculations from the rare-earth minerals in the Barringer Hill pegmatite (Becker, 1908, p. 134). These results are only of historical interest, and reliable dates were not obtained until much later. The granites of the three plutonic series yield ages of 1,030 m.y. by rubidium-strontium and potassium-argon methods (Zartman, 1964), and 990-1,070 m.y. by uranium-lead methods on zircon; ages from the Valley Spring Gneiss by rubidium-strontium methods are 1,120 m.y. (Zartman, 1965). The cycle of metamorphism and intrusion had a span of about 100 m.y. and is a Grenvillian event, termed for local purposes the "Llano orogeny" (Muehlberger and others, 1966, p. 4522); the rocks involved in it are classed as Precambrian Y.

\section{REGIONAL PROBLEMS}

It will be observed from the outcrop data just presented that there are three general ages of basement rocks in the south-central United States-approximately 1,000 m.y. in the Llano area, $500 \mathrm{~m} . \mathrm{y}$. in the Wichita area, and 1,200-1,400 m.y. in the Arbuckle and Ozark areas, each of which has also been recorded in buried basement rocks near the outcrops. The 1,000m.y. ages mark a Grenvillian province that probably connects with the surface and subsurface Grenville province east of the Mississippi River, although there is a wide intervening gap where basement rocks have not been reached by drilling. The $500 \mathrm{~m} . \mathrm{y}$. ages represent a Cambrian basement province unique in the North American interior. The 1,200-1,400 m.y. ages north of it recall the Elsonian event in the eastern Canadian Shield, and have been recorded in buried rocks over a wide expanse of the Interior Province, northward to the Wisconsin arch in the Lake Superior region, and eastward to the buried front of the Grenville belt in Ohio and Kentucky.

The regional meaning of the 1,200-1,400 m.y. set of dates is not clear. Do they express an age province like those in the Canadian Shield, with its own complex of metamorphic and plutonic rocks and with well-defined strucural boundaries against other provinces? Or does it result from extensive overprinting of later events on an earlier province? Available evidence is not decisive, because so much of it has been obtained from drill data, and so little from outcrops, but the second possibility seems more likely:

(1) The boundaries of the region are poorly defined, the Elsonian dates being mingled on the north with Hudsonian dates, and on the south with Grenvillian dates.

(2) Many of the dates recorded in subsurface are from plutonic bodies that might be younger than the complex in which they are embedded.

(3) This situation is true in the few outcrop areas. In the Nain province of the Canadian Shield, the Wisconsin arch of the Lake Superior Region, and the Precambrian of the Southern Rocky Mountains, plutons with 
Elsonian ages ( $\left.\mathrm{Yg}_{1}\right)$ are thickly spaced in metamorphic and plutonic complexes with Hudsonian ages (Xm, Xg). To some extent, this later plutonism has updated the ages in the surrounding complexes.

(4) Many of the Elsonian ages in the south-central States are from volcanic and other supracrustal rocks.

An impressive feature of the concealed basement of this region is the wide extent of little-deformed felsic volcanics with Elsonian and younger ages, that presumably overlie earlier complexes (fig. 15). In Missouri they have yielded ages of 1,200-1,350 m.y. (as in the St. Francois Mountains), in northeastern Oklahoma ages of 1,150-1,300 m.y., in the Texas Panhandle ages of 1,100-1,200 m.y., and in the Wichita belt ages of 525 m.y. (Muehlberger and others, 1966, p. 5422 and fig. 3). Associated with the Panhandle volcanics is a very extensive stratiform body of intrusive gabbro of somewhat younger age.

On the Geologic Map, we have provided for the plutonic rocks with 1,200-1,400 m.y. ages in unit $\mathrm{Yg}_{1}$

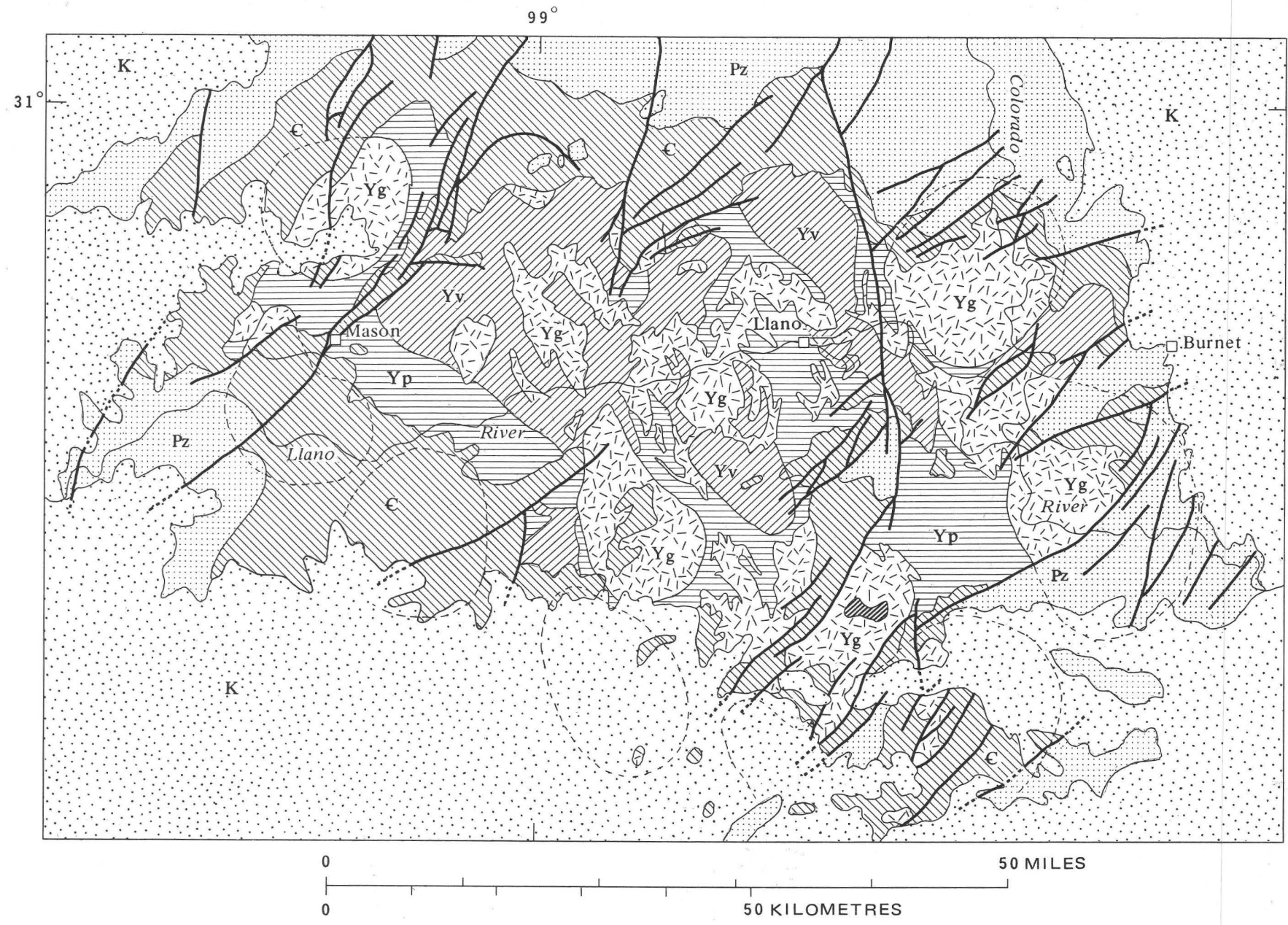

EXPLANATION
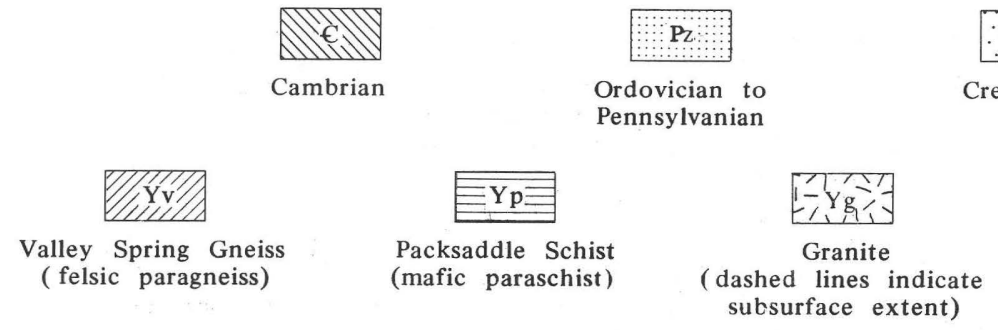

um

Ultramafic rocks

FigURE 14.-Map of Llano uplift, central Texas, showing Precambrian Y metamorphic and plutonic rocks, and their relation to surrounding Phanerozoic rocks. Compiled from Geologic Map of Texas (1937), Flawn and Muehlberger (1970, p. 78), and other sources. 
("older Precambrian Y granitic rocks"); metamorphic and supracrustal rocks with these ages are not distinguished separately from the remainder of Precambrian Y.

\section{CORDILLERAN REGION}

The outcrops of Precambrian rocks in the western United States are in the Cordilleran Region, a domain of later Phanerozoic orogenies which have raised the Precambrian to the surface in the higher uplifts. These outcrops are separated by $500 \mathrm{mi}(800 \mathrm{~km})$ or more of
Phanerozoic cover from those in the Lake Superior Region and elsewhere in the central United States, but much has been learned about the connections between them from drilling in the intervening plains.

The Precambrian provinces and structures are mostly transverse to the Phanerozoic structures and landforms of the Cordillera, and are only grossly related to them. Nevertheless, it will be useful to describe the Precambrian in terms of the modern morphology. Under the first heading we will therefore deal with the ancient Precambrian crystalline rocks (mainly Precam-

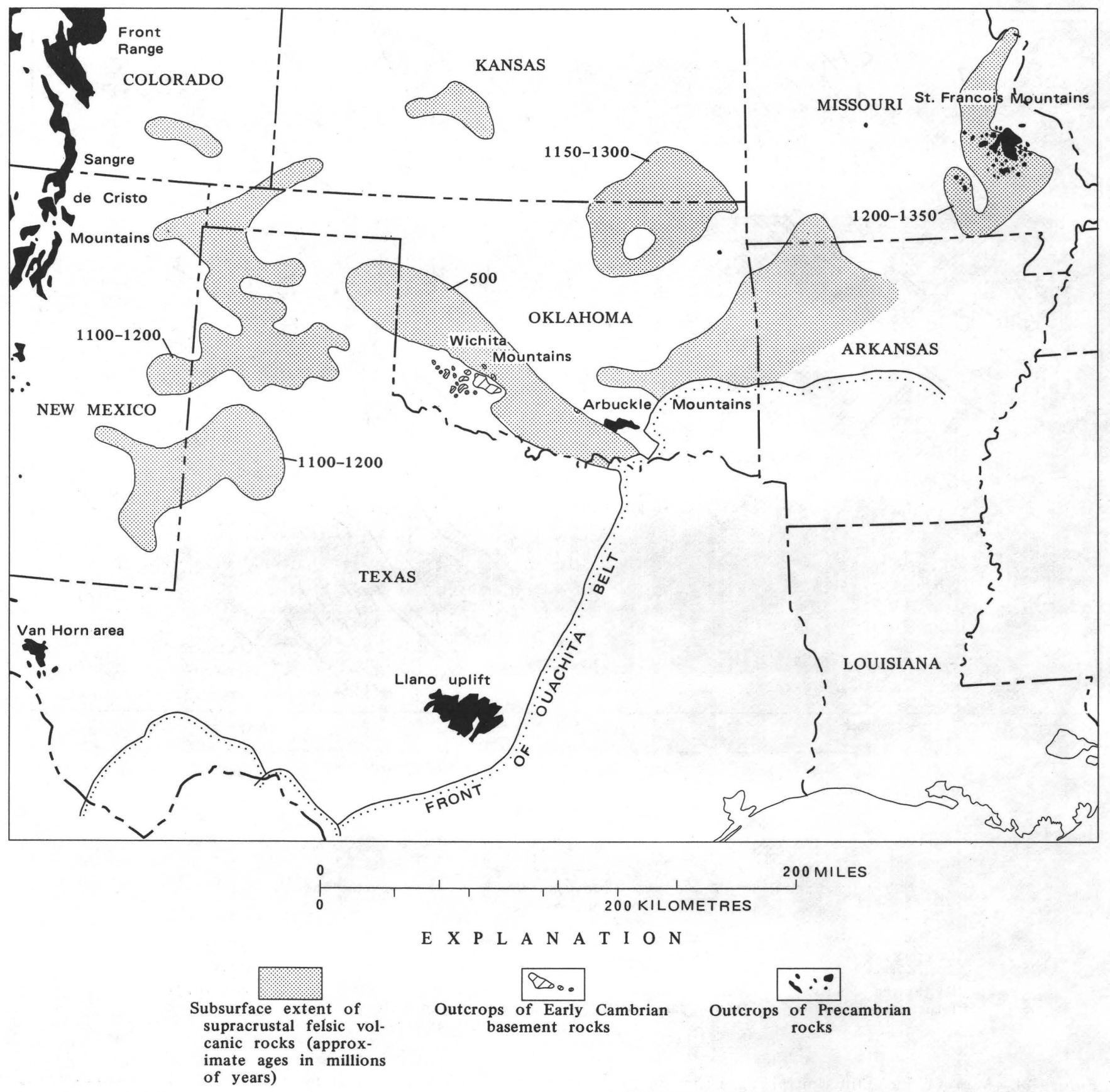

Figure 15.-Map of part of south-central United States, showing subsurface extent of late Precambrian and Early Cambrian supracrustal felsic volcanic rocks. Based on Muehlberger, Hedge, Denison, and Marvin (1966, p. 5422), and Bayley and Muehlberger (1968). 
brian W) of the Central Rocky Mountains in Wyoming and southern Montana; and following this the later Precambrian supracrustal rocks (Precambrian Y and Z) of the Northern Rocky Mountains in western Montana and adjacent Idaho. In a like manner, we will deal with the somewhat younger Precambrian crystalline rocks (mainly Precambrian X) of the Southern Rocky Mountains in Colorado and New Mexico; followed by the supracrustal rocks (Precambrian Y and Z) of the eastern Great Basin in Utah and adjacent States. In a final section, we will describe the varied Precambrian rocks of the southern Basin and Range province in Arizona and adjacent States.

\section{CENTRAL ROCKY MOUNTAINS}

For purposes of this account, the Central Rocky Mountains are the ranges of Wyoming and southern Montana, and the Black Hills of South Dakota. They are irregularly disposed, widely spaced, broad-backed mountain uplifts, many of which expose large areas of Precambrian rocks in their cores; they are separated by even broader areas of downwarped Phanerozoic rocks, whose plains and plateaus are more or less confluent with the Great Plains to the east. On the west and northwest they are bordered by the more closely crowded ranges of the main Cordilleran thrust belt. The Precambrian cores of many of the ranges project a mile or more above their surroundings, and some peaks attain altitudes of as much as $13,000 \mathrm{ft}(4,000 \mathrm{~m})$.

The larger areas of Precambrian in the Central Rocky Mountains are in the Black Hills of western South Dakota, well to the east of the others; in the Laramie and Medicine Bow Ranges of southern Wyoming; in the Wind River Mountains farther west in Wyoming and the Bighorn Mountains farther north; and in the Beartooth Mountains which straddle the boundary between northwestern Wyoming and southern Montana (fig. 16). Smaller Precambrian areas in some of the intervening ranges and to the northwest provide partial connections between the larger areas.

The dominant structures of the Central Rocky Mountains are a product of late Cretaceous-early Tertiary (Laramide) orogeny, in which the Precambrian basement participated. Although the Phanerozoic rocks are steeply tilted or faulted at the edges of the uplifts, their Precambrian cores were raised mainly as rigid blocks. As a result, the Precambrian rocks and their structures have been so little modified by Laramide and other Phanerozoic deformations that the effects can be disregarded.

The Precambrian of the Central Rocky Mountains is an extension of that of the Superior province of the Canadian Shield (fig. 17), and most of it is ancient crys- talline rocks with Kenoran or even earlier dates (Precambrian W); however, younger dates are reported in places in the subsurface of the intervening area (Goldich, Lidiak, Hedge, and Walthall, 1966, p. 5400, fig. 1), and there are important areas of outcrop of younger supracrustal rocks (Precambrian X) to the southeast and east. The southeastern boundary with the younger crystalline rocks of the Southern Rocky Mountains is a major structural discontinuity (Mullen Creek-Nash Fork shear zone) that crosses the Medicine Bow and Laramie Ranges, and can be traced in subsurface more than $200 \mathrm{mi}(320 \mathrm{~km})$ farther northeastward beneath the Great Plains. The northwestern boundary is the stratigraphic overlap of the Belt Supergroup (Precambrian Y) in central Montana.

\section{PRECAMBRIAN W}

The rocks in nearly all the ranges of the Central Rocky Mountains in Wyoming are gneiss (Wgn) and granite (Wg), and share a complex history that has only partly been deciphered. They have been studied in greatest detail in the Beartooth Mountains during a project under the direction of the late Prof. Arie Poldervaart (Eckelmann and Poldevaart, 1957; and later reports). Here and elsewhere, the oldest rocks are paragneisses, originally a thick supracrustal sequence of dominantly pelitic sediments and minor volcanics, that have been plastically folded and refolded, regionally metamorphosed to amphibolite grade, and partly converted to migmatite and granite; in addition, there are some postkinematic granite plutons, and the whole complex is crisscrossed by diabase dikes, formed during a late tensional phase.

Radiometric determinations on the rocks of all the ranges by potassium-argon, rubidium-strontium, and uranium-lead methods have yielded rather consistent Kenoran ages of about 2,750 m.y., but this seems to express merely the later orogenic events. Zircons of detrital origin from the gneisses of the Beartooth Mountains have yielded ages in excess of 3,100 m.y. and express an earlier event upon which the Kenoran event was superposed (Catanzaro, 1966, p. 9-11; Butler, 1966, p. 61). In the other ranges an earlier event of this kind can be inferred from the structural relations, but this has not been confirmed by radiometric dating.

A unique feature of the northwestern Beartooth Mountains is the Stillwater Complex (Wmi), a body of layered chromite-bearing mafic and ultramafic rocks with an exposed length of $30 \mathrm{mi}(48 \mathrm{~km})$ and a preserved thickness of 18,000 ft (5,500 m) (Jones and others, 1960, p. 283-286). It intrudes and overlies the prevailing gneisses and dips steeply away from them, under the unconformably overlying Cambrian on the flank of the 
range. The complex is younger than the 3,100-m.y.-old gneisses which it invades, and older than a 2,700-m.y.old quartz monzonite which truncates its eastern end. Potassium-argon and rubidium-strontium dating of the complex itself yields conflicting results (Kistler and others, 1968; Fenton and Faure, 1969), but it was probably emplaced nearer the later limiting date than the earlier.

Some of the ranges farther south in Wyoming expose downfolded belts of supracrustal rocks (W) much like those in the Superior province of northern Minnesota. In the South Pass (Atlantic City) district at the south end of the Wind River Mountains one of these belts contains $15,000 \mathrm{ft}(5,000 \mathrm{~m})$ or more of strata, beginning with basal iron formation and quartzite, followed by a thick body of turbidites, and greenstones with pillow structure (Bayley, 1968, p. 502-598). These are older than the Louis Lake Granodiorite to the north with an age of 2,690 m.y.

\section{PRECAMBRIAN COMPLEX OF SOUTHWESTERN MONTANA}

Precambrian crystalline rocks are exposed in southwestern Montana between the Beartooth Mountains and the Cordilleran thrust front on the west, in the Madison, Jefferson, Tobacco Root, Ruby, and other ranges. On the Geologic Map they are represented as Precambrian W like those in Wyoming, but they are somewhat more varied, their ages are less certain, and they are more involved with Phanerozoic features, such as Laramide plutons (Kg3), Cenozoic volcanism, and block faulting.

Three general rock types recur in the different

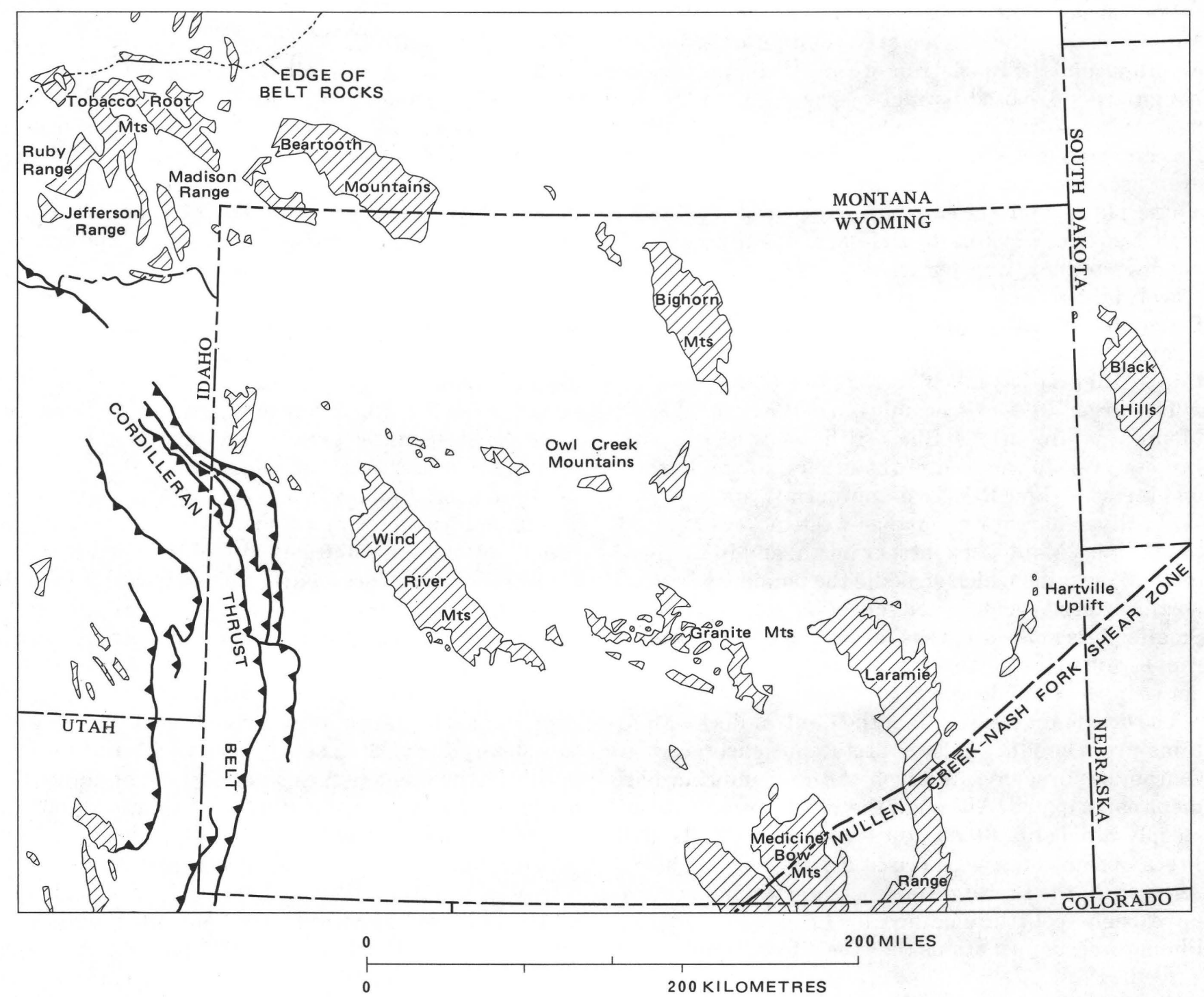

FiguRE 16.-Map of Central Rocky Mountains in Wyoming, South Dakota, and Montana, showing outcrops of Precambrian rocks and localities mentioned in text. 
ranges, called the Dillon (a granitic orthogneiss), the Pony (a mafic paragneiss), and the Cherry Creek (a sequence of metasediments and metavolcanics) (Scholten and others, 1955, p. 350-352; Reid, 1963); the first two are mapped as Wgn and the third as W. Their structure is complex and their mutual relations are still debated, but the components of the Cherry Creek are sufficiently distinctive to suggest that it may be a valid stratigraphic unit (H. L. James, oral commun., 1973). In the type Cherry Creek area in the Jefferson Range it includes mica schist, pillow lava, iron formation, quartzite, and dolomite marble (Hadley, 1969a, b); al-
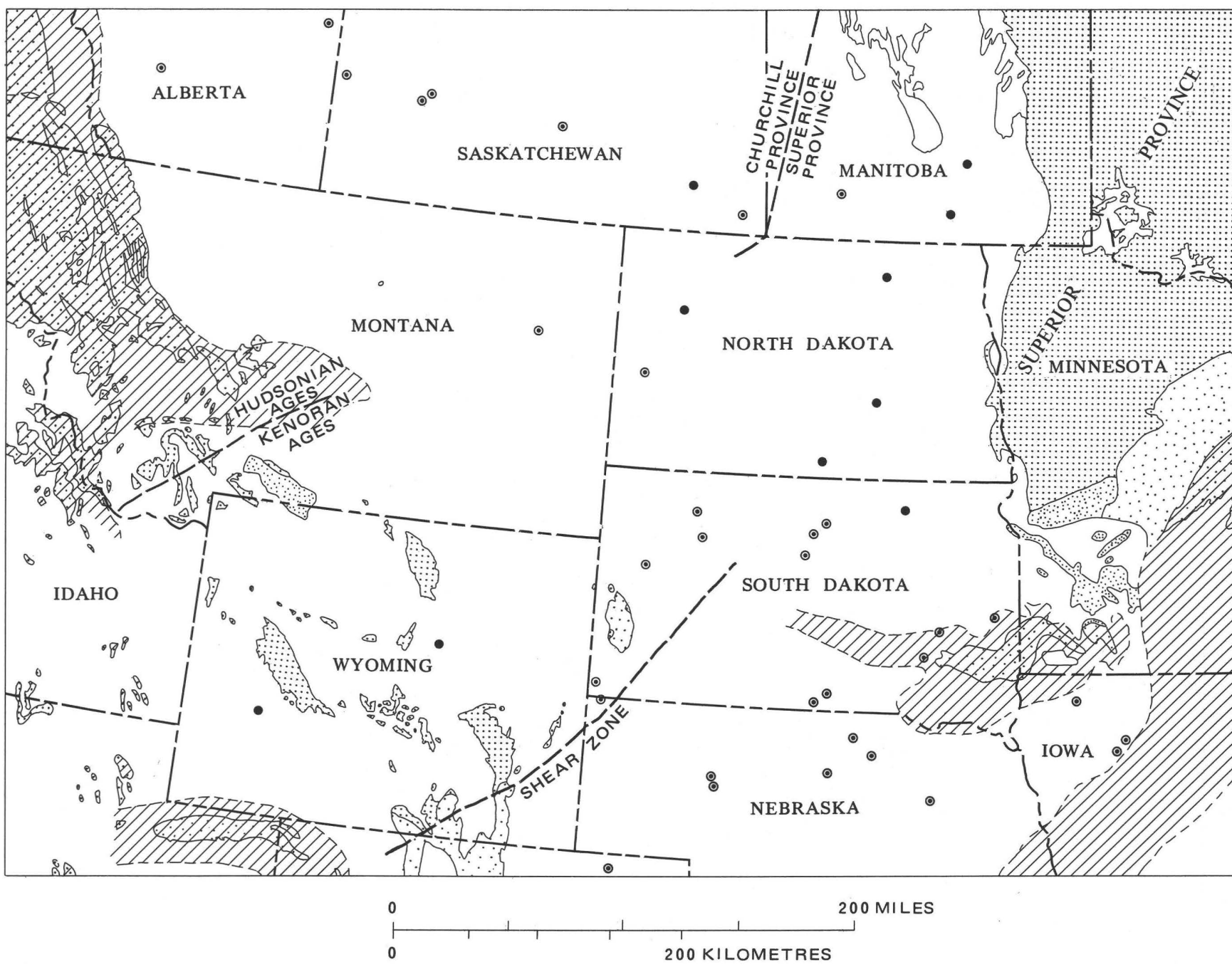

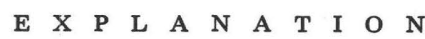

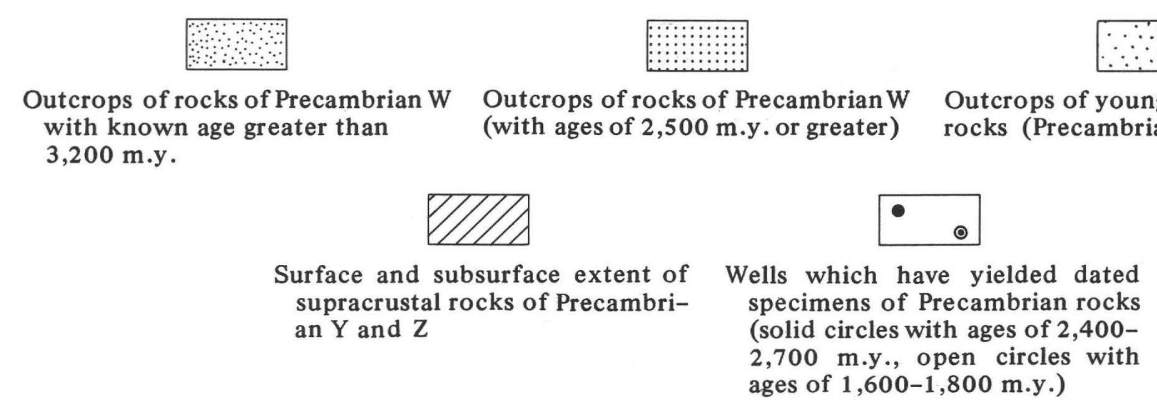

FIgURE 17.-Map of part of western United States and southern C anada, showing surface and subsurface extent of Precambrian W rocks in the Superior province of the Lake Superior Region, and westward to the Central Rocky Mountains. Compiled from geologic maps of United States (1974) and Canada (1969), and Goldich, Lidiak, Hedge, and Walthall (1966, p. 5390). 
though here classed as Precambrian $\mathrm{W}$, the prominent bodies of quartzite and marble are more characteristic of younger parts of the Precambrian in other regions.

Radiometric dating by potassium-argon and rubidium-strontium methods provides equivocal results. The rocks of the ranges toward the southeast yield dates in excess of 2,600 m.y., but identical rocks farther northwest have dates in the range of 1,600-1,800 m.y.; in addition, in the northernmost exposures are 175 m.y. dates produced by proximity to Laramide plutons (Giletti, 1966, p. 4031-4035). Apparently a Precambrian $\mathrm{W}$ terrane with original Kenoran dates has been downgraded toward the northwest by Hudsonian events. The westernmost granitic rocks of Dillon type yield rather consistent 1,600 m.y. ages and are therefore mapped as $\mathrm{Xg}$; they may represent a younger pluton that is at least partly responsible for the mixing of Kenoran and Hudsonian dates.

Farther north, Precambrian crystalline rocks reappear in the core of the Little Belt Mountains uplift, where they form the basement of the Belt Supergroup. The varied rocks include paragneiss, migmatite, granite gneiss, and diorite. Radiometric determinations by a variety of methods yield dominant ages of about 1,900 m.y., but zircons from the paragneiss and migmatite have ages as great as 2,450 m.y. (Catanzaro, 1966, p. 13-15). Here, as in southwestern Montana, Hudsonian dates are mingled with Kenoran dates, and the Little Belt crystalline rocks are accordingly mapped as Wgn.

The mingling of Kenoran and Hudsonian dates in southwestern Montana and the Little Belt Mountains seems to represent a gradational boundary between two major Precambrian provinces, analogous to the Superior and Churchill provinces of the Canadian Shield. Here, however, in contrast to conditions in the Shield, there seems to be no sharply marked structural or stratigraphic boundary between the two provinces.

A final comment should be made on the crystalline rocks in the core of the mantled gneiss domes of the Albion Range in southern Idaho and northwestern Utah, for which rubidium-strontium whole-rock isochron yields an age of 2,460 m.y. (Armstrong and Hills, 1967 , p. 118-120). This occurrence is $200 \mathrm{mi}(320 \mathrm{~km})$ west of the Precambrian W rocks in the Central Rocky Mountains, and represents the farthest known extension of the Superior province in the United States.

\section{PRECAMBRIAN X}

In the eastern and southeastern part of the Central Rocky Mountains, as here delimited, younger Precambrian supracrustal rocks (X) are emplanted in the prevailing ancient crystalline terrane (Wgn, $\mathrm{Wg}$ ). They form most of the exposed Precambrian in the Black
Hills, and smaller areas in the Hartville uplift and Medicine Bow Mountains to the southwest. All of them have yielded Hudsonian dates and are classed as Precambrian X, but considerable differences in lithology and sequence among the several areas preclude more exact correlations.

In the Black Hills of western South Dakota, Precambrian rocks are exposed in a northward-elongated oval area of about $900 \mathrm{mi}^{2}\left(2,300 \mathrm{~km}^{2}\right)$ on the crest of the dome (fig. 18). All the Precambrian was surveyed in reconnaissance during the early part of the century by Sidney Paige (in Darton and Paige, 1925). Economic work was done later near the Homestake gold mine at the north end of the area (Noble and Harder, 1948; Noble and others, 1949) and in the pegmatite district in the southern part (Page and others, 1953), but comprehensive regional mapping is of rather recent date (Redden, 1963, 1968; Ratté and Wayland, 1969; Bayley, 1970, 1972a, b, c).

The rocks are a sequence of metamorphosed sediments and minor volcanics more than $40,000 \mathrm{ft}$ $(12,000 \mathrm{~m})$ thick, steeply or isoclinally folded along northerly axes, and in places curiously refolded. In the northern half they form a gross synclinorium plunging toward the south. Here, the lower part of the sequence is in the Nemo district on the eastern side (Runner, 1934), which adjoins basement granite on Little Elk Creek (Wgn) with a Kenoran age of 2,500 m.y. (Zartman and Stern, 1967). A thick basal quartzite is succeeded unconformably by an equally thick conglomerate with associated beds of iron formation, schist, and limestone. The upper part of the sequence, which forms the rest of the exposure to the west, is a eugeosynclinal deposit originally laid down as graywacke, slate, graphitic slate, chert, and pillow lava. It contains several thin but very persistent formations of ferruginous cherty rock, one of which (the Homestake Formation) contains the gold ore at the Homestake Mine.

Less is known of the overall stratigraphic sequence in the southern hills. Basement rocks with a Kenoran date (Wgn) project in a mantled gneiss dome at Bear Mountain on the western side. Farther east, at Harney Peak and elśewhere, large granitic plutons $(\mathrm{Xg})$ have domed the already folded and faulted supracrustal rocks (Runner, 1943) and are surrounded by swarms of pegmatites. The granites and pegmatites have been dated by potassium-argon and uranium-lead methods at 1,620 1,680 m.y., and were intruded during late kinematic or postkinematic phases of the "Black Hills" (= Hudsonian) orogeny (Goldich, Lidiak, Hedge, and Walthall, 1966, p. 5401)

At the crest of the northern Medicine Bow Mountains of southern Wyoming is another great sequence of supracrustal rocks, that was deciphered years ago by 
Blackwelder (1926). It lies on basement gneisses (Wgn) $\mid$ separates it from the crystalline complex of the Central on the north, and dips steeply and homoclinally southward to the Mullen Creek-Nash Fork shear zone, which

Rocky Mountains (Xm, etc.) (fig. 19). At the base of the sequence, which totals $35,000 \mathrm{ft}(11,000 \mathrm{~m})$ in all, is a

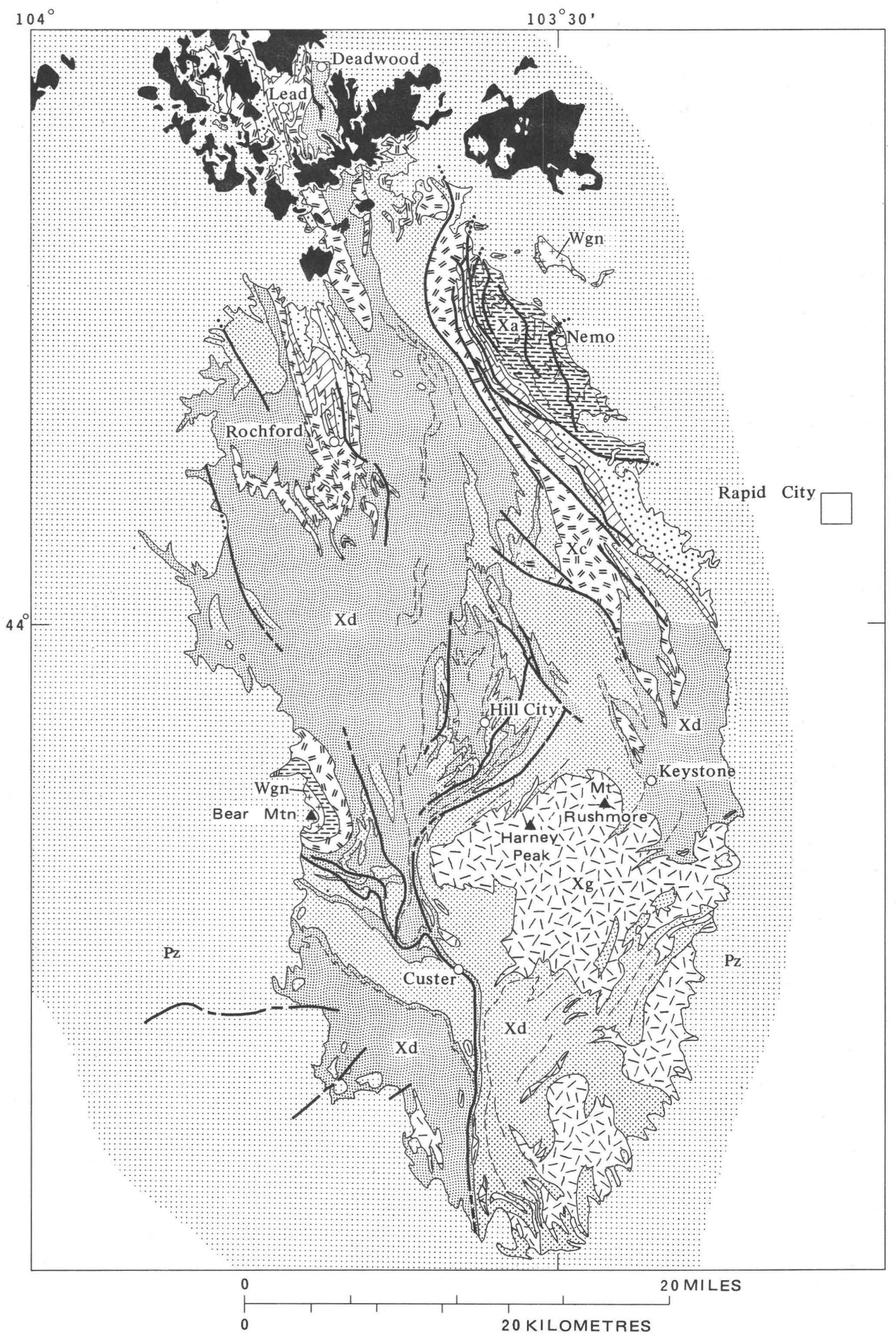

EXPLANATION

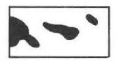

Tertiary intrusive rocks

$$
\begin{gathered}
\text { Pz } \\
\text { Paleozoic } \\
\text { (with } \begin{array}{c}
\text { Upper Cambrian } \\
\text { at base) }
\end{array}
\end{gathered}
$$

PRECAMBRIAN X

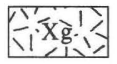

Harney Peak Granite 1,620-1,680 m.y.

EUGEOSYNCLINAL SEQUENCE

$$
\begin{aligned}
& \text { Schist and slate, with thin to } \\
& \text { thick bodies of graywacke and } \\
& \text { quartzite (stippled) } \\
& \text { Pillow basalt, iron formation, } \\
& \text { and slate or schist } \\
& \text { Slate; and quartzite (stipple) } \\
& \text { with Homestake Iron- } \\
& \text { formation at base in north } \\
& \text { MIOGEOSYNCLINAL } \\
& \text { SEQUENCE }
\end{aligned}
$$

\section{$\because \because \times 17: 0$}

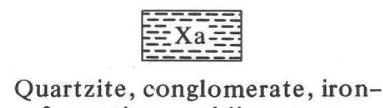
formation, and limestone

PRECAMBRIAN W

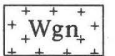

Little Elk Granite (in northeast) and granite gneiss at Bear Mountains (in southwest) $2,500 \mathrm{~m} . \mathrm{y}$.

$$
-----
$$

Contacts within map units

$$
\text { Precambrian faults }
$$

Phanerozoic faults

FIGURE 18.-Map showing Precambrian rocks in the Black Hills, western South Dakota. Compiled from many sources, including Paige (in Darton and Paige, 1925), Noble and Harder (1948), Noble and others (1949), Redden (1963, 1968), Ratté and Wayland (1969), and Bayley 1970, 1972a, b, c). 
thick body of quartzite (Deep Lake Formation), followed unconformably by a more varied set of formations (Libby Group), including probable tillite in the lower part, several prominent quartzite units, and higher up, slates, greenstone volcanics, and carbonates with abundant, well-preserved stromatolites (Houston and others, 1968, p. 15-38). The general aspect of the sequence is miogeosynclinal, in contrast to the eugeosynclinal aspect of most of the Black Hills sequence.
Rubidium-strontium whole-rock isochrons indicate that the Medicine Bow sequence is older than 1,550 m.y. and younger than the basement gneiss at 2,350-2,400 m.y. (Hills and others, 1968, p. 1776).

\section{PRECAMBRIAN Y}

In the Laramie Range east of the Medicine Bow Mountains, the position of the Mullen Creek-Nash Fork shear zone is occupied by an anorthosite body (Ya)

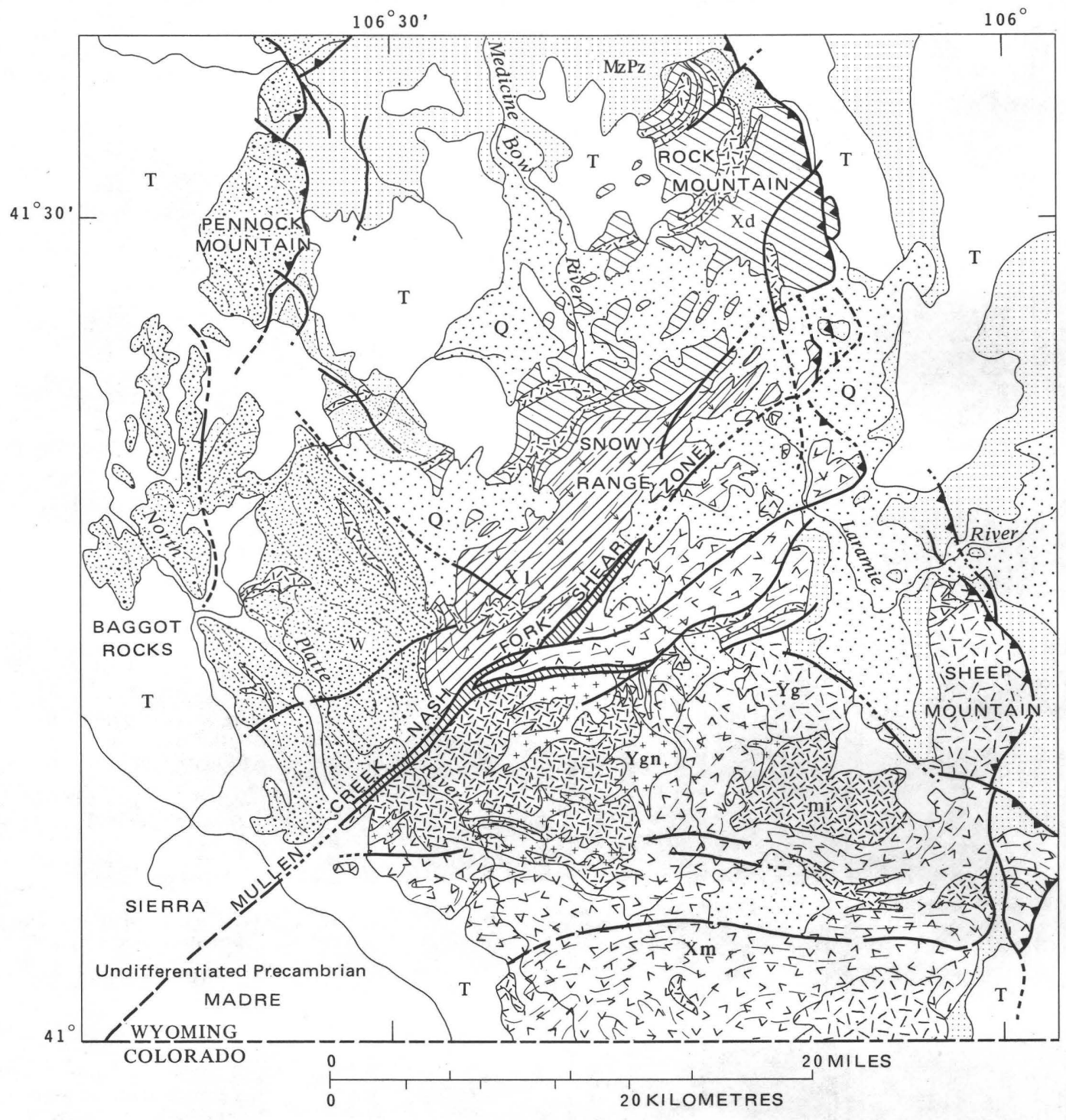

EXPLANATION

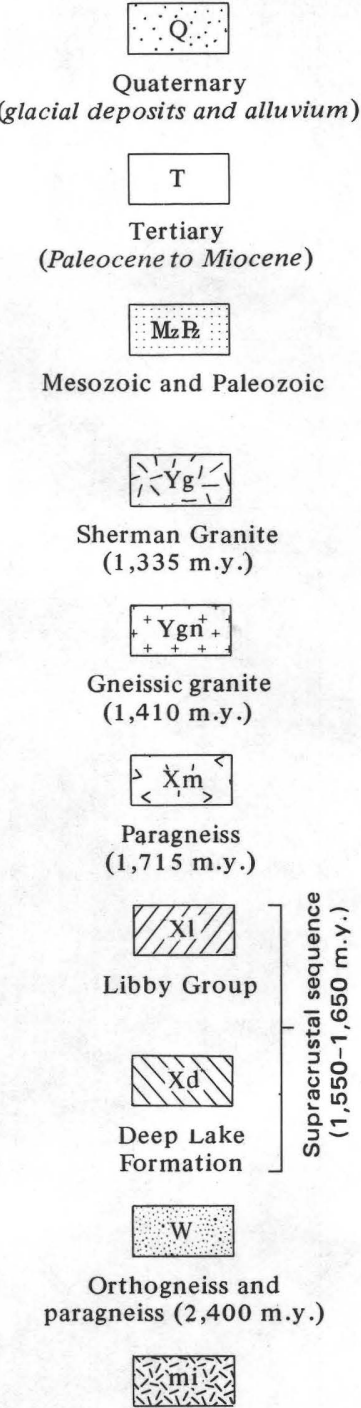

Mafic intrusives (various Precambrian ages)

Cataclastic rocks in shear zone

FIGURE 19.--Map of northern Medicine Bow Mountains, Wyo., showing rocks of Precambrian W and X, and their relation to surrounding Phanerozoic rocks. The Mullen Creek-Nash Fork shear zone separates the Precambrian provinces of the Central and Southern Rocky Mountains. Generalized from Houston and others (1968) and Hills and others (1968). 
with an area of about $300 \mathrm{mi}^{2}\left(780 \mathrm{~km}^{2}\right)$ (Newhouse and Hagner, 1957); it intrudes the ancient gneisses (Wgn) which form the northern part of the range, and it is intruded in turn by the Sherman Granite (Yg1) which forms the southern part. The anorthosite has a minimum age of 1,510 m.y. by potassium-argon methods on hornblende (Hills and Armstrong, 1971), and the granite has been dated at 1,410 m.y.

\section{NORTHERN ROCKY MOUNTAINS}

The Northern Rocky Mountains in this account are the mountainous terrain of western Montana and northern Idaho. Most of the southwestern half of the mountains is occupied by the great plutonic mass of the Mesozoic Idaho batholith (Kg, Kgn), but a large part of the remainder, northward across the International Boundary into Canada, is formed of supracrustal rocks of later Precambrian age-mainly the Belt Supergroup (Y), but including the less extensive younger Windermere Group (Z) on the northwest.

\section{PRECAMBRIAN $Y^{11}$}

The Belt Supergroup, or "Beltian" (= Purcell Supergroup in Canada), is exposed nearly continuously across an area of about $30,000 \mathrm{mi}^{2}\left(78,000 \mathrm{~km}^{2}\right)$ in the United States and an additional $10,000 \mathrm{mi}^{2}\left(26,000 \mathrm{~km}^{2}\right)$ in Canada-the greatest expanse of well-preserved Precambrian supracrustal rocks in the country. Throughout much of this expanse the Belt is merely tilted or warped, broken into coarse-textured fault blocks, and subjected only to the lower grades of metamorphism-a truly remarkable preservation of rocks so ancient through the 900 m.y. of succeeding Precambrian and Phanerozoic time. The Belt remained little disturbed until the Mesozoic and early Tertiary Cordilleran orogenies (Laramide and earlier).

As a result of these orogenies, much of the Belt is allochthonous, having been transported scores of miles eastward along the Lewis and other low-angle thrusts, across the Paleozoic and Mesozoic rocks of the Cordilleran miogeosyncline and foreland. Southwestward, also, it is invaded and disrupted by the Idaho batholith and other Mesozoic plutons, near which it is regionally metamorphosed to amphibolite grade. In this western area there is, besides, a gneissic terrane ( $\mathrm{Ym})$ which exceeds the adjacent Belt in its metamorphic complexity, but which may have been converted from Beltian rocks by the plutonic activity (Clark, 1973).

Through a large part of its extent, the Belt is the

${ }^{11}$ For a summary of data on the Belt Supergroup available up to 1963, see Ross $(1963,1970)$ later information and developments for the part in Canada are given by Price (1964) and Gabrielse (1972, p. 522-528), and for the part in the United States by Harrison (1972) and Harrison and others (1974 youngest rock preserved, but outliers of Paleozoic occur on it in places, and it passes beneath Paleozoic and younger rocks at the edges. The next overlying unit is generally the Middle Cambrian Flathead Quartzite, which is separated from the strata beneath by little or no structural discordance. This relation has created a persistent misconception that the Belt must be very late Precambrian, if not Early Cambrian; Daly (1912, p. 174-190) even proposed an elaborate correlation of most of the Belt with the Lower and Middle Cambrian formations farther north in the Rocky Mountains. Much later, Deiss (1935) demonstrated the extensive regional truncation of the Belt beneath the Middle Cambrian deposits (although his results are somewhat vitiated by an assumption of constant thickness of the different Belt formations). Moreover, a decade earlier Walker (1926, p. 13-20) had discovered the later Precambrian Windermere Group unconformable over the Belt on the northwest, thus proving that the Belt itself was much earlier Precambrian than anyone had hitherto suspected. (See p. 53.)

Along its southeastern side, in the Little Belt Mountains and the Three Forks region of southwestern Montana, the Belt lies on older Precambrian crystalline basement (Wgn) with Kenoran and Hudsonian dates (p. 46-48). Near Three Forks the Belt abuts southward against a rough and partly upfaulted highland of the crystalline rocks, near which it assumes a coarse bouldery facies (LaHood Formation), quite unlike the normal fine-grained Belt sediments (McMannis, 1963); this is a local feature. An eastward wedging out of the Belt deposits on their basement must also exist north of the Little Belt Mountains, where the line of overlap is now concealed beneath the Lewis thrust plate. Farther west in the expanse of Belt rocks their basement nowhere reaches the surface; moreover, all the rocks west of the Belt area are younger, so that there is no indication of any western borderland.

Along the eastern edge of its exposure, as in the Belt Mountains and Glacier National Park, the Belt is about $20,000 \mathrm{ft}(6,100 \mathrm{~m})$ thick, and is readily divisible into half a dozen or a dozen distinctive formations, including two prominent carbonate units (Newland = Altyn below, Helena = Siyeh above), several units of bright red argillite, and (near the International Boundary) the Purcell Lava, the only volcanic rock in this sequence, or elsewhere in the Belt.

This facies is marginal to the main area of Belt deposits to the west. Near the probable center of its original depositional basin, observed partial sequences of the Belt are 50,000 ft (15,000 m) thick, and the whole thickness probably exceeds $65,000 \mathrm{ft}(20,000 \mathrm{~m})$. Here, contrasts in the deposits have faded and formation boundaries are blurred. Most of the deposits are 
siltstones, grading on the one hand into argillites and on the other into fine-grained quartzites. Red colors have turned to drab; the carbonates become calcareous siltstones with a few thin limestone interbeds. A remarkable feature of the sequence is the indication nearly throughout of deposition in shallow water, as shown by mud cracks, cut-and-fill, casts of salt crystals, and other sedimentary structures. All indications are that this great mass of fine sediment was derived from cratonic areas to the east and southeast.

As will be seen presently, radiometric data indicate that accumulation of the Belt sediments occupied a span of nearly 500 m.y.-a length equal to most of Phanerozoic time since the beginning of the Ordovician. Even the great known total thickness of the Belt seems inadequate the account for this time span on the assumption of continuous sedimentation. This has led to a proposal that the Belt sequence must contain several hidden unconformities, expressing lengthy time gaps (Obradovich and Peterman, 1968, p. 746). It is true that some unconformities have been observed from place to place, but they seem to be minor and local. The best guess may be that there was "long semicontinuous deposition of sediments, interrupted by many hiatuses" (Harrison, 1972, p. 1237).

Many different local names have been given to subdivisions of the Belt Supergroup from one district to another, both in the United States and Canada, and correlations between them have been much debated. Increasing knowledge in recent decades has clarified most of the relations and has led to recognition of gross regional subdivisions. Within the main area of Belt outcrops their pattern is sufficiently coarse textured that they can be distinguished on the Geologic Map. On the map, it is therefore feasible to represent a unit $\mathrm{Y}_{1}$, of siltstones, argillites, and quartzites, that includes the Prichard Formation and Ravalli Group of the southwestern area; a unit $\mathrm{Y}_{2}$, of carbonates and calcareous siltstones, that includes the Wallace Formation on the west and the Helena and Siyeh Limestones farther east; and a unit $\mathrm{Y}_{3}$, again siltstones, argillites, and quartzites, that comprises the Missoula Group. Similar gross subdivisions are also recognizable in some of the smaller outlying areas, especially to the southeast, but cannot be shown on the scale of the map; these areas are indicated merely as undifferentiated Y.

The fresh appearance of the Belt rocks and their well-preserved sedimentary structures have impelled geologists since the days of Walcott (1899, p. 235-239) to search for the remains of fossils. The search has revealed abundant and well preserved stromatolites in the carbonate rocks at many levels, which seem to be capable of at least local zonation (Rezak, 1957); and other probable organisms such as bacteria. Traces of more advanced, metazoan forms of life have also been claimed, such as burrows, trails, and shell fragments, but these are questionable and some of them are clearly inorganic sedimentary structures. A supposed brachiopod, Obolella montana Fenton and Fenton, is evidently an algal stromatolite (Cloud, 1968, p. 27-29).

Radiometric data on the age of the Belt are rather extensive for a Precambrian stratified sequence, but some of the evidence that they afford is indirect, and some of it is equivocal and conflicting (Obradovich and Peterman, 1968; Harrison, 1972, p. 1234-1238). Absolute age limits of the Belt sequence are set by the 1,700 m.y. dates from its crystalline basement and the 760 m.y. age of a vein cutting its upper part (Garnet Range Formation of Missoula Group). From the Belt sediments themselves, dates have been obtained at nearly a dozen levels from base to top on glauconite, biotite, and argillite by rubidium-strontium and potassium-argon methods, which range from more than 1,300 m.y. to less than 900 m.y.; also, the Purcell Lava and associated intrusives near the base of the Missoula Group ( $\mathrm{Y}_{3}$ ) have yielded a potassium-argon date of about 1,100 m.y. In addition, dates of about 1,500 m.y. have been obtained from gneisses (Ym) probably derived from lower Belt rocks, but their significance is questionable. Available evidence thus suggests that Belt sedimentation took place over at least 400 m.y., and perhaps as much as 500 m.y. Further evidence regarding the time of termination of Belt sedimentation is afforded by dates from the succeeding Windermere Group.

\section{PRECAMBRIAN OF CENTRAL IDAHO}

In east-central Idaho, southeast of the Idaho batholith and north of the Snake River Plain, the Paleozoic in the various ranges is underlain by a thick sequence of clastic sedimentary rocks which are commonly considered to be equivalents of the Belt Supergroup and are accordingly shown on the Geologic Map as Precambrian Y. Their character and sequence have recently been summarized by Ruppel (1975).

Their total thickness probably exceeds $30,000 \mathrm{ft}$ $(9,150, \mathrm{~m})$, but their structure is complex, largely owing to Mesozoic deformation, and the whole sequence is not exposed in any one area. They have been subjected to low-grade regional metamorphism in the chlorite and biotite zones, and additional metamorphism has been superposed to the northwest near the batholith. The sequence is divided into the Yellowjacket Formation below, followed by the Lemhi Group of five formations, and the Swager Formation.

The sedimentary rocks of the area resemble those of the typical Belt in being a very thick sequence of clastic sediments, lying stratigraphically between the older 
Precambrian crystalline rocks to the east and the overlying Paleozoic. In detail, however, the rocks of the two areas have surprisingly little in common. In contrast to the dominantly silty rocks of the Belt, those of central Idaho are mainly fine- to medium-grained feldspathic sandstones. Limestone and dolomite are virtually lacking, and stromatolites are rare. The sandstones show none of the shallow-water sedimentary structures of the Belt rocks. Observers have been unable to find any points of resemblance between details of the two sequences which would suggest correlations, and a proposed correlation based on general sequence (Ruppel, 1975 , p. 18) is tenuous indeed. One reason for the differences seems to be that the central Idaho sequence of Precambrian sediments and the overlying Paleozoic have been transported a long distance eastward from their original site of deposition by Mesozoic thrusting; accumulating evidence indicates that the distance of transport was more than $100 \mathrm{mi}(160 \mathrm{~km})$. Two Precambrian sedimentary basins with different environments of deposition have evidently been brought into juxtaposition.

Additional data on the Precambrian of central Idaho have been presented by Armstrong (1975). He finds that granitic gneisses near Salmon, Idaho, shown on the Geologic Map as an eastern lobe of the Idaho batholith, have yielded ages of about 1,500 m.y. by rubidiumstrontium methods, hence are early Precambrian Y. This has many implications. It suggests that the rocks that extend across and nearly bisect the middle of the batholith are of early Precambrian age. On the Geologic Map, indeed, an extremely metamorphosed part of them is represented as Xm, but Armstrong believes that the remainder, shown on the map as metamorphosed Belt (Y) or as "border phase of the Idaho batholith" (Kgn) deserve the same classification also. Furthermore, the 1,500 m.y.-old gneisses apparently intrude the central Idaho Precambrian sedimentary sequence just discussed, which would imply that it is of pre-Belt ageeither early Precambrian Y or Precambrian X. The observations so far made on these interesting problems are as yet insufficient to provide positive answers, and they deserve much further investigation.

\section{PRECAMBRIAN Z}

Overlying the Belt Supergroup on its northwestern border is the Windermere Group, a younger Precambrian supracrustal sequence. Its typical development is in the Purcell and Selkirk Mountains of southeastern British Columbia, whence it extends northward through most of the length of the Canadian part of the Cordillera (Gabrielse, 1972, p. 529-531). It also projects southward into the northeastern corner of Washington
State, as in the Metaline district (Park and Cannon, 1943 , p. 7-13), but is preserved here only in small disconnected remnants (Z). Parts of the Windermere have been known for many years; the part along the International Boundary was the "Summit Series" of Daly (1912, p. 141-159), who thought it was equivalent to the Belt farther east. Recognition of these different parts as a new and hitherto unknown entity first came with Walker (1926, p. 13-20), whose discovery was one of the major contributions to North American Precambrian geology of this century. Nevertheless, the Windermere has remained strangely unknown, ignored, or misinterpreted by most geologists in the United States, even until today.

The Windermere lies unconformably on the Belt and marks the beginning of a new cycle of sedimentation. Local discordances between the two sequences are slight, but regionally the Windermere lies on different units of the upper Belt; its basal beds contain abundant clasts of the Beltian rocks, a few of which have been metamorphosed. The unconformity expresses an event called the "East Kootenay orogeny" which involved epeirogenic uplift in the Purcell Mountains, and local plutonic intrusions (Gabrielse, 1972, p. 528-529).

Within the main geosynclinal area on the west, the Windermere sedimentary cycle continued nearly unbroken into the Paleozoic. (In fact, the higher units of Walker's original Windermere, the Hamill, Lardeau, etc., have since yielded Lower Cambrian fossils, and are now excluded.) Eastward and marginally, a disconformity develops at the top; in the Banff-Jasper segment of the Rocky Mountains the Windermere (Miette Group) is unconformable below the Lower Cambrian quartzites. No fossils have been reported in the restricted Windermere, except for Chuaria in the Miette Group (Gussow, 1973), like that in the Chuar Group of the Grand Canyon (p. 68).

The Windermere in southeastern British Columbia and adjacent Washington is as much as $15,000-20,000$ $\mathrm{ft}(4,600-6,100 \mathrm{~m})$ thick-modest compared with the preceding Belt deposits, but impressive nevertheless. Near the International Boundary the sequence comprises (from below upward) the Toby (= Shedroof) Conglomerate, the Irene (= Leola) Volcanics, and the Horsethief Creek (= Monk) Formation, the latter followed by the Hamill (= Gypsy) Quartzite of Lower Cambrian age. (Farther south in Washington the first two units are combined as the Huckleberry Formation).

The Irene is a mafic pillow lava and interbedded tuff that wedges out a short distance north of the boundary. The Toby is a regional deposit of variable thickness; much of it is coarse diamictite, formed of clasts of all sizes, largely of Beltian rocks, but including a few of granite and gneiss from the craton farther east. Diamic- 
tites recur in the lower part of the Monk (probably connecting with the main body of the Toby farther north), but most of it is a heterogeneous mixture of phyllite, carbonate rocks, and quartzite. The Toby (and the basal Monk) was probably a glacial marine deposit, fed by ice on adjoining lands to the east, seemingly the local expression of a worldwide epoch of refrigeration that occurred late in Precambrian time (Aalto, 1971, p. 778-784).

The time of beginning of Windermere sedimentation (and by implication the end of Belt sedimentation) is an important level in the Precambrian evolution of the Cordilleran region, but is indicated by only sparse radiometric data. Determinations on the granitic stocks in the Purcell area that are thought to have originated during the "East Kootenay orogeny" yield equivocal results-potassium-argon dates of 705-770 m.y. and a rubidium-strontium isochron of 1,260 m.y. (Gabrielse, 1972 , p. 528); if the latter is near the true age, the intrusives must have been emplaced during deposition of the later Belt sediments. The volcanics in the lower part of the Windermere in Washington State (Irene equivalent) have recently yielded potassium-argon dates on whole rocks and mineral separates of 829-918 m.y. (Miller and others, 1973), which suggests that Windermere sedimentation probably began about 300 m.y. before the beginning of the Cambrian.

\section{SOUTHERN ROCKY MOUNTAINS ${ }^{12}$}

The Southern Rocky Mountains are the ranges that extend southward from Wyoming, through the center of Colorado, into northern New Mexico. These ranges, like those of the Central Rocky Mountains, are broadbacked uplifts that expose large areas of Precambrian rocks in their cores, but they differ from those farther north in being closely crowded together rather than dispersed, so that their intervening lowlands are much narrower. Eastward, the Southern Rocky Mountains front abruptly on the Great Plains, whereas westward they merge with the Colorado Plateau through intermediate ridges and plateaus (fig. 20).

Facing the Great Plains is the Front Range, a massive upland $250 \mathrm{mi}(400 \mathrm{~km})$ long and $30-60 \mathrm{mi}(50-95 \mathrm{~km})$ broad; it branches northward in Wyoming into the Laramie and Medicine Bow Ranges, and terminates in southern Colorado in the appendage of the Wet Mountains. South of this termination the Sangre de Cristo Mountains rise from behind and form the frontal ridge southward into New Mexico, to their own termination near Santa Fe. West of the Front Range is the equally

${ }^{12}$ For a useful summary of Precambrian rocks and events in the Southern Rocky Mountains, and their relation to Phanerozoic rocks and events, see Tweto, 1968, p. 555-571. lengthy but narrower Park Range, and beyond that the short and massive Sawatch Range, $90 \mathrm{mi}(145 \mathrm{~km})$ long and $40 \mathrm{mi}(65 \mathrm{~km})$ broad, which culminates in the highest summit of the Rocky Mountains (Mount Elbert, $14,431 \mathrm{ft}, 4,399 \mathrm{~m})$. Beyond the Sawatch Range are lower uplifts, still roofed over by Phanerozoic strata, in which Precambrian is revealed in the deeper cuts and canyons: the White River Plateau to the northwest, the Uncompahgre Plateau to the west, and nearer at hand, the uplift along the Gunnison River, whose Black Canyon exposes Precambrian rocks in sheer walls $2,300 \mathrm{ft}$ $(700 \mathrm{~m})$ high. Southwest of the Sawatch Range is the broad Cenozoic volcanic field of the San Juan Mountains, at the southwestern edge of which the Precambrian projects again in the domical Needle Mountains.

The gross surface features of the Southern Rocky Mountains, as farther north, are a product of late Cretaceous-early Tertiary (Laramide) orogeny, but here plutonic and volcanic activity was greater. One result of the activity is the Colorado mineral belt that extends diagonally northeastward across all the ranges (Tweto and Sims, 1963, p. 993-996), containing most of the prolific mineral deposits of Colorado and marked by numerous faults, veins, and intrusive stocks, as well as the large Mount Princeton pluton in the southern Sawatch Range (Kg3, Ti).

Relations in the Southern Rocky Mountains are complicated further by Phanerozoic orogenic events earlier than the Laramide, especially during the later Paleozoic, when geanticlines and troughs were created that had a somewhat different pattern from the Laramide structures-a Front Range geanticline on the sites of the Front Range and northern Park Range, and an Uncompahgre-San Luis geanticline on the sites of the Uncompahgre Plateau and San Juan Mountains (fig. 20) (Mallory, 1972).

In the Southern Rocky Mountains the gross patterns of the Precambrian rocks and structures are plainer than farther north because of the close proximity of the ranges, but they are confused in detail because of the more complex Phanerozoic events. Confusion is greatest in the Colorado mineral belt, where the Laramide plutonism, faulting, and mineralization are superposed on ancestral shear zones that originated during Precambrian time. Erosion and sedimentation resulting from the Paleozoic orogenies produced contrasts between the strata that lie on the Precambrian from place to place: lower Paleozoic shelf deposits in the troughs (as in the Sawatch Range), upper Paleozoic clastic deposits on the flanks of the geanticlines (as in the Front Range and Sangre de Cristo Mountains), and Mesozoic strata on the crests of the geanticlines (as in the Uncompahgre Plateau). 
PRECAMBRIAN X GNEISS COMPLEX

The Precambrian of the Southern Rocky Mountains is a complex of paragneisses, in which are embedded numerous small to large granitic plutons. South of the Mullen Creek-Nash Fork discontinuity in southern

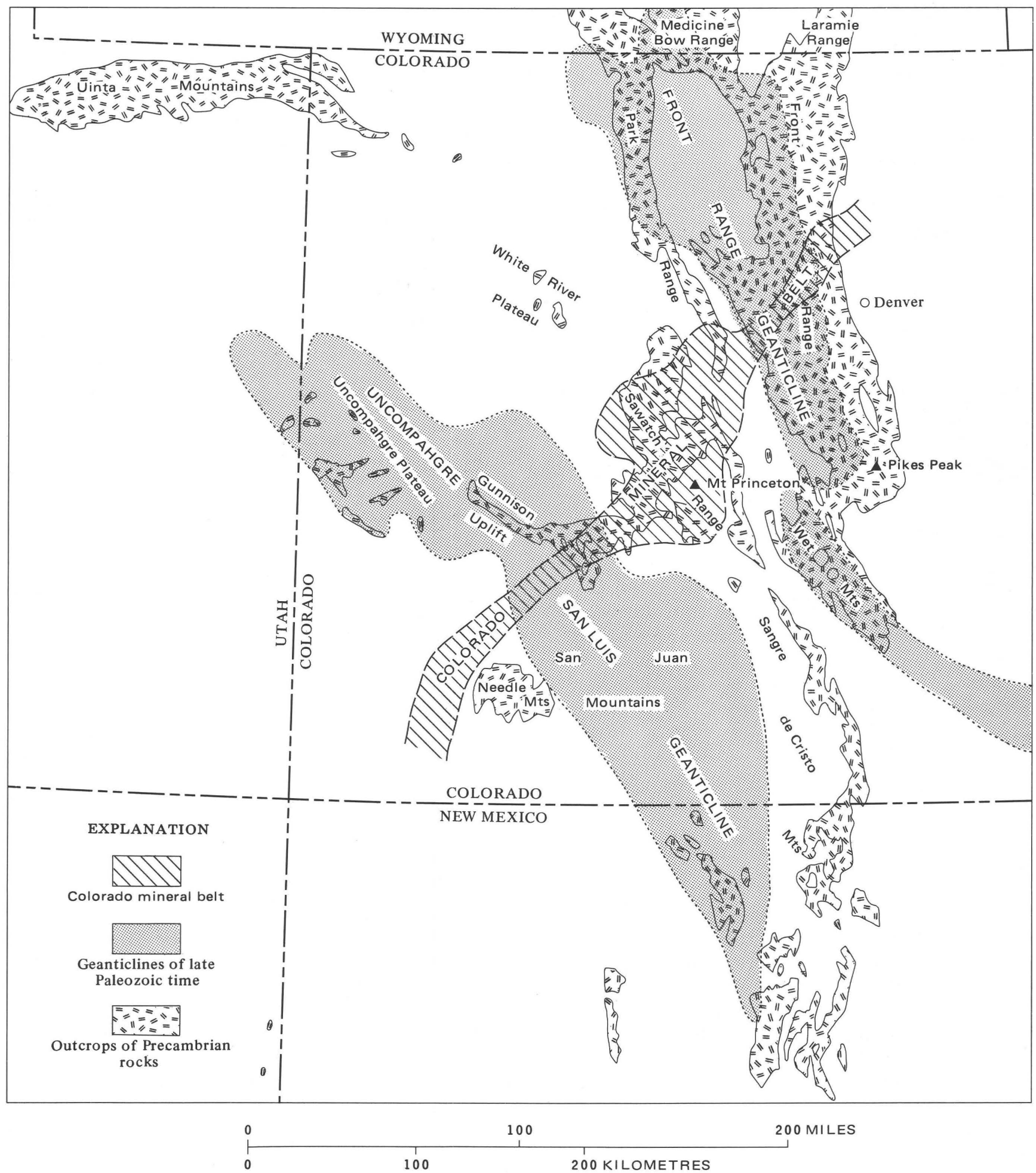

Figure 20.-Map of Southern Rocky Mountains in Colorado and New Mexico, showing outcrops of Precambrian rocks, outlines of the late Paleozoic geanticlines and the Colorado Mineral Belt, and localities mentioned in the text. Outlines of Colorado Mineral Belt and Paleozoic geanticlines after Tweto and Sims (1963, p. 997, 1007) and Mallory (1972, p. 132). 
Wyoming all the Precambrian rocks yield Hudsonian and later dates and no Kenoran dates are known. All the rocks of the Southern Rocky Mountains are therefore Precambrian X or younger and no rocks of Precambrian $\mathrm{W}$ are identifiable, if indeed they ever existed.

The dominant paragneiss (Idaho Springs Formation of Front Range) is a biotitic quartzo-feldspathic gneiss derived from an original thick geosynclinal sequence of shale and graywacke, in which are numerous lenses and interbeds of amphibolite (Swandyke Gneiss of Front Range), derived from original volcanic rocks. The only prominent variant is a thick synclinal mass of quartzite at the mountain front northwest of Denver (Wells and others, 1964). The gneisses have been plastically deformed into steep folds along northwest to westnorthwest axes, and metamorphosed to almandineamphibolite grade. Relicts of an earlier, more open folding of about the same trend can be detected in places, and superimposed on both sets of structures is a later cataclastic deformation that produced northeasttrending shear zones, especially in the Colorado mineral belt about midway along the Front Range and in the northern Sawatch Range (Tweto and Sims, 1963, p. 996-1005).

The main deformation of the paragneisses has been dated by rubidium-strontium methods on whole-rock and feldspar samples at 1,750 m.y.; the earlier deformation and the original accumulation of the sediments could have been no more than 100 m.y. earlier (Hedge and others, 1967, p. 555); the gneisses are accordingly classed as Xm on the Geologic Map. They may be the eugeosynclinal equivalent of the miogeosynclinal Precambrian X rocks of the northern Medicine Bow Mountains (Hills and others, 1968, p. 1777).

PRECAMBRIAN X AND Y GRANITIC ROCKS

Embedded in the paragneisses are granitic rocks which form nearly half the area of Precambrian exposure. In the Front Range and elsewhere they are divisible into three groups of different ages, each younger group emplaced at progressively shallower levels in the crust (Peterman and Hedge, 1968, p. 753-754).

The oldest group $(\mathrm{Xg})$, exemplified by the Boulder Creek Granite of the Front Range, forms concordant plutons in the paragneisses and is synorogenic to their principal deformation, with Hudsonian ages of about 1,700 m.y. The much more extensive middle group (Yg1), exemplified by the Sherman Granite of the Laramie Range and the Silver Plume Granite of the Front Range farther south, is broadly contemporaneous with the final cataclastic deformation of the gneisses, and yields Elsonian ages of 1,390-1,450 m.y. The youngest group (Yg2), or Pikes Peak Granite, occurs only in the southern part of the Front Range, where it forms a great pluton with an exposed area of 1,200 $\mathrm{mi}^{2}$ $\left(3,100 \mathrm{~km}^{2}\right)$, and several satellite bodies; it is postorogenic and has a Grenvillian age of about 1,040 m.y. (Hedge, 1970).

\section{PRECAMBRIAN OF NEEDLE MOUNTAINS}

The Precambrian of the Needle Mountains, at the edge of the San Juan volcanic field in southwestern Colorado, is more varied than elsewhere in the Southern Rocky Mountains, hence has long intrigued geologists, but relations have only been clarified recently by detailed mapping and by radiometric dating (Barker, 1969; Bickford and others, 1967, p. 1660-1661) (fig. 21).

An older metamorphic complex (Xm) consists of the Vallecito Conglomerate with clasts derived from still older terranes, followed by the Irving Formation of amphibolite, paragneiss, and metagraywacke. The complex was steeply folded along northerly to northeasterly axes, metamorphosed to amphibolite grade, and invaded by the synkinematic Twilight Granite and the postkinematic Tenmile Granite, with rubidium-strontium ages of 1,780 m.y. and $1,700-1,720$ m.y., respectively.

Lying with right-angled unconformity on the deeply eroded edges of the metamorphic and plutonic rocks is theUncompahgre Formation (Y), a supracrustal sequence of quartzite and interbedded slate more than $8,000 \mathrm{ft}(2,400 \mathrm{~m})$ thick; it was steeply folded along west-northwest axes before intrusion of the Eolus Granite with an age of 1,460 m.y. (Yg1). Still younger minor granites with ages of 1,350 m.y. intrude the rocks of the older complex in places.

The time of accumulation and deformation of the Uncompahgre Formation is bracketed between the age of the youngest preceding granite $(1,700 \mathrm{~m} . \mathrm{y}$.- and the age of the oldest succeeding granite (1,460 m.y.) (fig. 22). The formation is therefore early Precambrian Y (Paleohelikian of the Canadian classification), and thus probably largely older than the Precambrian Y Belt Supergroup of the Northern Rocky Mountains. Its deformation is an Elsonian event (the "Uncompahgre orogeny" of local terminology)—a deformation of which there is little indication elsewhere in the western United States.

\section{EASTERN GREAT BASIN}

The eastern Great Basin in the western half of Utah and the eastern edge of Nevada is a region of interior drainage leading mainly into Great Salt Lake; it is a terrain of isolated or nearly isolated ranges that project from broad expanses of lowland floored by late Cenozoic deposits. Along its eastern border more cohesive plateaus and ranges face it in prominent escarpments, 
of which the most notable are the Wasatch Mountains $\mid$ the Uinta Mountains, actually an outpost of the Southin the north, whose summits stand $7,000 \mathrm{ft}(2,100 \mathrm{~m})$ above the basin floor. Also included in this account are ern Rocky Mountains, which extend $150 \mathrm{mi}(250 \mathrm{~km})$ eastward from the Wasatch Mountains at midlength.

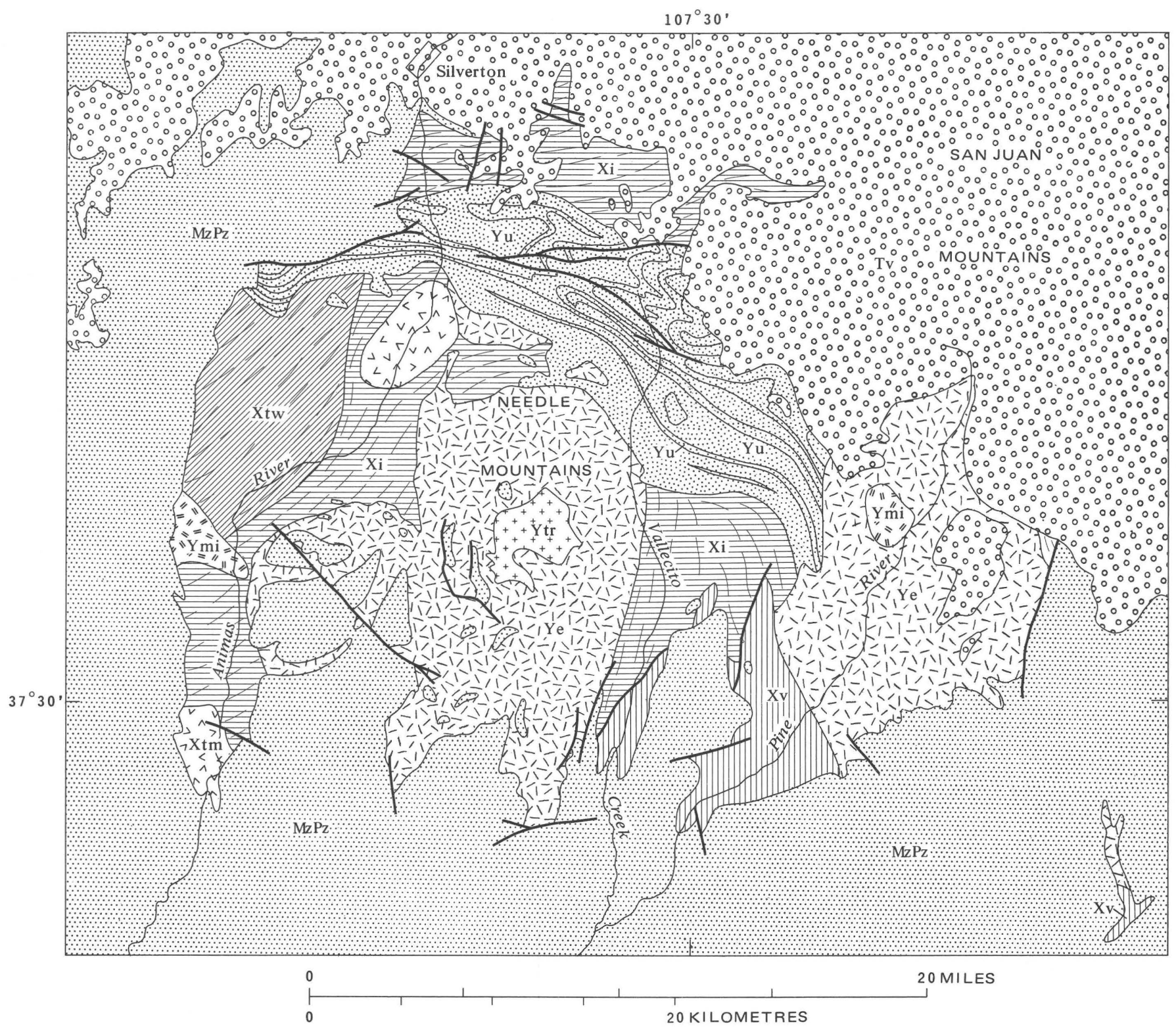

EXPLANATION

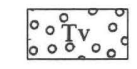

Tertiary volcanic rocks

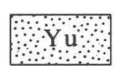

Uncompahgre Formation (quartzite with argillite layers)

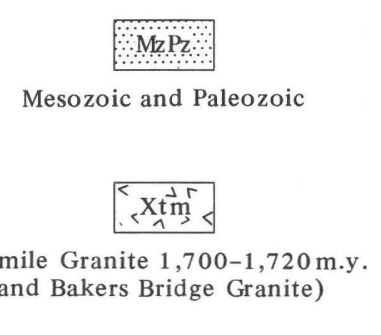

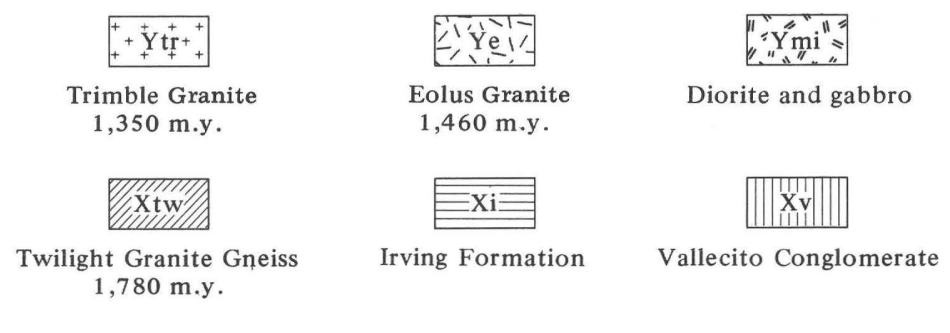

Figure 21.-Map showing Precambrian X and Y units in Needle Mountains, southwestern Colorado. After Barker (1969), with Phanerozoic rocks added from other sources. 


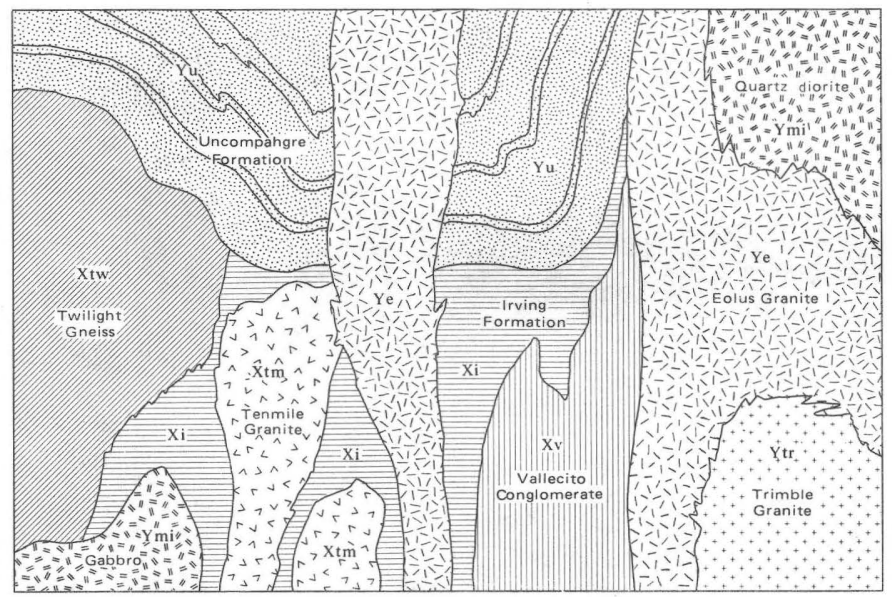

Figure 22.-Synoptic diagram showing relations of units of Precambrian X and Y in Needle Mountains, southwestern Colorado, and their implications in the Precambrian history of the area. Letter symbols the same as in fig. 21. After Barker (1969, p. A8).

The gross forms of the region are of younger origin than those in the Rocky Mountains to the east and north-products of a late Cenozoic disruption that outlined the ranges and lowlands of the Great Basin by block-faulting, and separated it from the Wasatch Mountains and other uplands on the east. The late Cenozoic disruption is superposed on an earlier Cordilleran fabric, largely a product of Mesozoic orogenies, and especially of a mid-Cretaceous (Sevier) orogeny; this, in turn, is superposed on a preceding Phanerozoic miogeosynclinal regime.

The late Cenozoic boundary between the disrupted region on the west and the more stable region on the east follows a persistent zone of weakness (Wasatch line), which had previously been the front of the Sevier orogenic belt, and the edge of the preceding miogeosyncline. The traces of the frontal thrusts of the orogenic belt are close to the block-faulted late Cenozoic boundary, lying west of it in the central Wasatch Mountains and south of the Wasatch Mountains, and east of it in the northern and southern segments of the Wasatch Mountains. About $100 \mathrm{mi}(160 \mathrm{~km})$ west of the frontal thrusts, near the Utah-Nevada border, a zone of décollement in the lower part of the miogeosynclinal sequence emerges in the cores of the ranges which is probably genetically related to the frontal thrusts to the east. Beneath it is an infrastructure that was highly disturbed and metamorphosed during the Mesozoic orogenies.

Within the region here considered, most of the exposed bedrock is Phanerozoic, but the underlying Precambrian emerges in small areas on the lower slopes of some of the ranges-mainly Precambrian Y and Z su- pracrustal rocks, but including some Precambrian $\mathrm{X}$ crystalline basement toward the east (fig. 23). As the frontal thrusts of the Mesozoic orogenic belt involve more than $30 \mathrm{mi}(50 \mathrm{~km})$ of eastward transport, great contrasts exist between the Phanerozoic and Precambrian rocks in the autochthon beneath the thrusts, and in the allochthon of the upper plates, contrasts which are especially evident in the Wasatch Mountains.

Autochthonous Precambrian rocks occur in the 60-mi (95 km) middle segment of the Wasatch Mountains and in the Uinta Mountains to the east. Allochthonous Precambrian rocks lie above them in the upper plate of the frontal thrust (Willard thrust) in the northern segment of the Wasatch Mountains, but do not come to the surface at the front of the upper plate in the southern segment. In the discussion which follows, the autochthonous Precambrian will be treated first, after which the allochthonous Precambrian of the northern Wasatch Mountains and farther north and west will be considered.

\section{CRYSTALLINE BASEMENT (PRECAMBRIAN X)}

Crystalline basement (Xm) of the autochthon is exposed in the central segment of the Wasatch Mountains, in one of the islands in Great Salt Lake immediately to the west (fig. 23), and on the northern edge of the Uinta Mountains, $150 \mathrm{mi}(250 \mathrm{~km})$ to the east.

The Farmington Canyon Complex (Eardley and Hatch, 1940a) forms the frontal ridge of the Wasatch Mountains for $25 \mathrm{mi}(40 \mathrm{~km})$ between Ogden and Salt Lake City. It is a body of felsic paraschist of amphibolite grade, derived from an original sedimentary sequence more than $10,000 \mathrm{ft}(3,000 \mathrm{~m})$ thick, that has been thoroughly permeated by granitic and pegmatitic material. About $15 \mathrm{mi}(25 \mathrm{~km})$ farther south the Little Willow Formation forms a small outcrop between the mouths of Big and Little Cottonwood Canyons (not shown on Geologic Map, but see fig. 23); it is likewise a paraschist but lacks injected material, in this respect resembling the Red Creek Quartzite of the Uinta Mountains (see below). The Little Willow is succeeded by Precambrian Y supracrustal rocks, but these wedge out northward, and the Farmington Canyon is overlain directly by the basal Cambrian Tintic Quartzite. The Farmington Canyon has yielded Hudsonian dates of 1,640-1,700 m.y. by potassium-argon methods on hornblende, and somewhat younger dates by rubidium-strontium methods on muscovite (Whelan, 1970 , p. 15-17). No Precambrian ages have been obtained from the Little Willow, and only dates between 27-29 m.y. that were produced by the nearby Tertiary plutons.

Near the east end of the Uinta Mountains on their north side the Red Creek Quartzite forms a small inlier 
at the base of the Precambrian Y Uinta Mountain Group (Hansen, 1965, p. 22-32). Determinations on muscovite from the Red Creek by rubidium-strontium and potassium-argon methods have yielded ages of 2,320 m.y. and 1,520 m.y., respectively. The larger figure is probably near the minimum age of the formation, which would place its accumulation in the early part of Precambrian X, or even in Precambrian W. Nevertheless, its general aspect is much like the Precambrian X rocks to the east and west, and it is so represented on the Geologic Map.

\section{BIG COTTONWOOD FORMATION (PRECAMBRIAN Y)}

In the Cottonwood area southeast of Salt Lake City, the Little Willow crystalline basement is followed unconformably by the Big Cottonwood Formation (Y), a 16,000 -ft $(5,000 \mathrm{~m})$ sequence of quartzites and interbedded variegated shales (Eardley and Hatch, 1940b, p. 819-820; Crittenden and others, 1952 , p. 3-4). Its rocks are not metamorphosed except near the Tertiary plutons, and they dip gently eastward beneath the Precambrian $\mathrm{Z}$ and Cambrian supracrustal rocks farther back in the mountains. Ripple marks, crossbedding, and mud-flake conglomerates are well preserved, indicating deposition in shallow water. Like the other Precambrian supracrustal rocks of the eastern Great Basin, no radiometric data are available on the age of the Big Cottonwood, but on the basis of relations to the rocks above and below, it is commonly believed to be equivalent to some part of the Precambrian Y Belt Supergroup of the Northern Rocky Mountains.

MINERAL FORK TILLITE AND MUTUAL FORMATION (PRECAMBRIAN \%)

In the upper reaches of Big Cottonwood and adjacent canyons, two higher Precambrian units intervene between the Big Cottonwood Formation and the Cambrian Tintic Quartzite-the Mineral Fork Tillite and Mutual Formation (Z) (fig. 23).

The Mineral Fork Tillite, or diamictite, is a massive graywacke in which are embedded numerous clasts of all sizes up to large boulders, with interbedded layers of quartzite and laminated argillite. Some of the clasts are striated, and all are of Precambrian crystalline basement, such as granite gneiss, quartzite, and dolomite. The deposit thickens and thins over the eroded surface of the Big Cottonwood Formation, reaching more than $1,000 \mathrm{ft}(300 \mathrm{~m})$ in broad, smooth-bottomed basins, and nearly disappearing in the intervening areas. A glacial origin for the deposit was proposed by various early geologists, such as Blackwelder (1932, p. 301-303), and has been reaffirmed by some modern observers (Crittenden and others, 1952 , p. 4-6), but questioned by others (Condie, 1967, p. 1,341-1,342), who compare it with subaqueous mudflows and turbidites of other regions. Such features could, of course, be one of the manifestations of a general glacial episode, and the reality of such an episode is strongly suggested by the regional occurrence of the Mineral Fork and correlative diamictites throughout the eastern Great Basin (Crittenden and others, 1972).

The Mutual Formation is a body of red-purple quartzites and red to green shales as much as $1,200 \mathrm{ft}$ $(360 \mathrm{~m})$ thick, which lies on the eroded surface of the Mineral Fork, and is truncated in turn by the Tintic Quartzite.

The position of the Mineral Fork and Mutual Formations between the Big Cottonwood Formation and the Tintic Quartzite implies a late Precambrian, and probably a Precambrian $\mathrm{Z}$ age, comparable to that of the Windermere Group in the Northern Rocky Mountains.

\section{UINTA MOUNTAIN GROUP (PRECAMBRIAN Y)}

The Uinta Mountains, like the other ranges of the Central and Southern Rocky Mountains, are a broadbacked anticlinal uplift, in part faulted on the flanks, with a large area of Precambrian exposed in the core. The core rocks are, however, not a crystalline basement, but a thick supracrustal clastic sequence, the Uinta Mountain Group (Y).

The Uinta Mountain Group lies on the crystalline basement of the Red Creek Quartzite, exposed near the eastern end of the range, and is moderately unconformable beneath the Paleozoic strata on the flanks, which include discontinuous thin Cambrian units at the base-Middle Cambrian to the west, Upper Cambrian to the east. The group is broadly arched, in conformity with the general uplift of the range, and is virtually unmetamorphosed. In the eastern exposures a complete sequence between the Red Creek Quartzite and the Paleozoic is $25,000 \mathrm{ft}(7,600 \mathrm{~m})$ thick (Hansen, 1965, p. 33); farther west, where the basement does not crop out, no more than about $10,000(3,000 \mathrm{~m})$ is exposed (Wallace and Crittenden, 1969, p. 129).

The Uinta Mountain Group contains various mappable subdivisions, but the only formally named unit is the Red Pine Shale, at the top in the western half of the range, a body of dark shale, siltstone, and minor quartzite as much as $5,000 \mathrm{ft}(1,500 \mathrm{~m})$ thick. The underlying main body of the group is dominantly quartzite and arkose, with shale only as thin interbeds. Three different facies are recognizable, representing contrasting sedimentary environments: deltaic-fluvial, fluvial-flood plain, and paralic-neritic (Wallace and Crittenden, 1969, p. 134-137). Sediments were derived from bordering lands of crystalline basement to the 
north and northeast, and were transported westward along the axis of the depositional trough. Quartzites and arkoses are especially coarse and massive in the eastern exposures, where they contain thick wedges of pebble and cobble conglomerate formed of rounded quartz and quartzite clasts (Hansen, 1965, p. 36-37).

Both the present extent of the Uinta Mountain Group beyond its outcrops, and its original extent, are difficult to determine because the Uinta Mountains are flanked north and south by the Green River and Uinta basins, filled by Phanerozoic sediments so thick that their base has not been reached by drilling. Nevertheless, the group seems to be an unusual eastward extension of Precambrian supracrustal rocks into a domain otherwise formed of crystalline basement. Such crystalline rocks (with Kenoran dates) are known some distance to

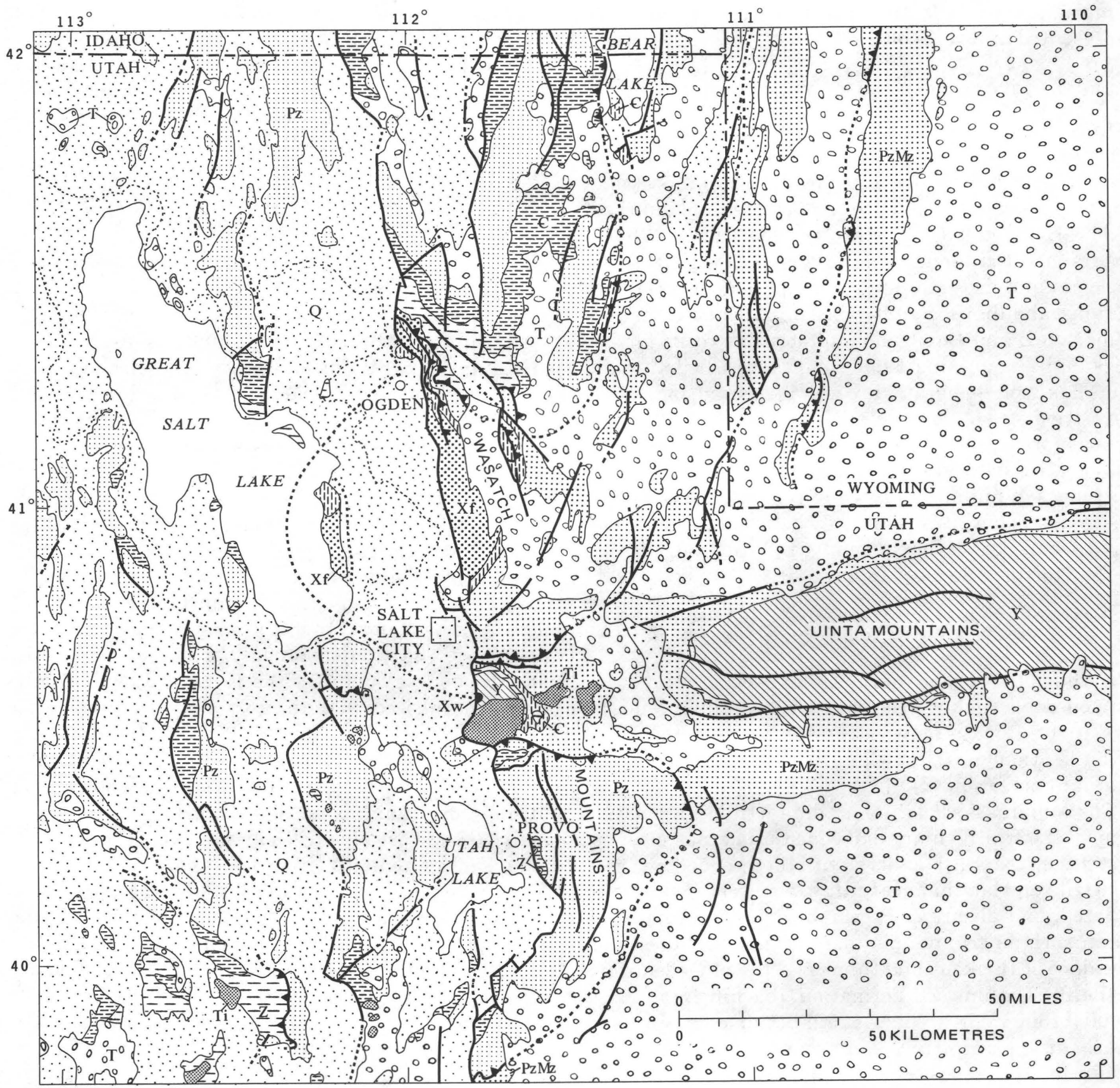

FIGURE 23.-Geologic map of northeastern Utah, showing Precambrian X, Y, and Z rocks in eastern Great Basin, and the adjoining mountains and plateaus to the east, which are parts of the allochthon and autochthon of the Cretaceous Sevier orogenic belt. Com- " piled from Geologic Map of Utah (1963), with additions from published and manuscript data of M. D. Crittenden, Jr. 
the north, near the Wind River Mountains, and others (with Hudsonian dates) are known from drilling along the south edge of the Uinta basin (Muehlberger and others, 1966, p. 5425). These occurrences define vaguely an east-trending belt of Precambrian supracrustal rocks that is probably a primary feature, as attested by the sedimentary facies in the group itself. The belt is comparable to the aulacogens of the Soviet geologists, or early sedimentary troughs which extend transversely into the craton.

The westward prolongation of the Uinta Mountain trough is in the Cottonwood area of the autochthonous central segment of the Wasatch Mountains, with its sequence of Precambrian Y and Z supracrustal rocks, already described. Its northern flank is in the northern part of the autochthonous segment, where the supracrustal rocks are missing, and the basal Cambrian lies directly on the earlier crystalline basement of the Farmington Canyon Complex (fig. 23).

The age of the Uinta Mountain Group has aroused speculation since the first geological explorations of the Uinta Mountains a century ago. Former proposals that it is of early or even late Paleozoic age are obsolete, as its unconformable position beneath Cambrian strata is now established. Modern speculation centers around its precise correlation with the Precambrian supracrustal units in the autochthonous segment of the Wasatch Mountains to the west. Is it equivalent, wholly or in part, to Precambrian Y Big Cottonwood Formation, or to the younger Precambrian $\mathrm{Z}$ Mineral Fork and Mutual Formations? No tillites (diamictites) like those in the Mineral Fork occur in the Uinta Mountains, yet a considerable part of the Uinta Mountain Group beneath the Red Pine Shale is lithically much like the Mutual Formation, and has been so correlated. Nevertheless, the marked variations in sedimentary facies within the Uinta Mountain Group itself warn of the dangers of correlations on lithology alone, and it might be an onshore phase of the Big Cottonwood Formation. The best present judgment on paleogeographic grounds seems to be that the Uinta Mountain Group is Precambrian Y (Crittenden and others, 1972, p. 337), a decision adopted on the Geologic Map. Recently a whole rock isochron by rubidium-strontium methods of 950 m.y. has been obtained from the Red Pine Shale at the top of the sequence (Zell Peterman, written commun. 1974), which confirms this inference.

\section{SUPRACRUSTAL ROCKS OF THE ALLOCHTHON}

(PRECAMBRIAN Z)

Along the eastern edge of the Great Basin, Precambrian rocks are exposed in widely separated ranges of $300 \mathrm{mi}(480 \mathrm{~km})$, from southeastern Idaho to southcentral Utah. In Idaho, they occur near Pocatello, in ranges immediately south of the Snake River Plain. In Utah, they are exposed in the northern segment of the Wasatch Mountains, in the Promontory Range west of

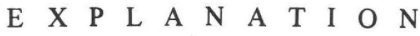
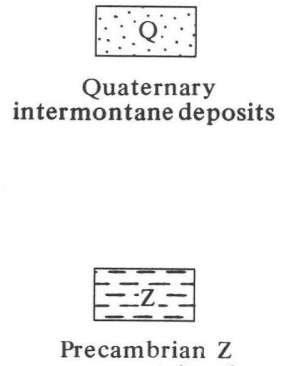
supracrustal rocks

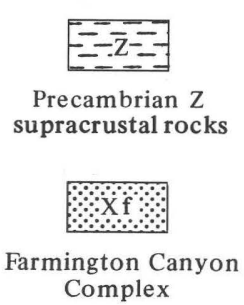

Figure 23.-Continued.

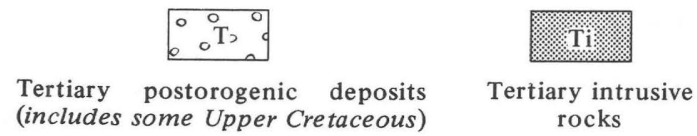

ROCKS OF THE ALLOCHTHON
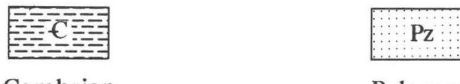

Paleozoic

ROCKS OF THE AUTOCHTHON
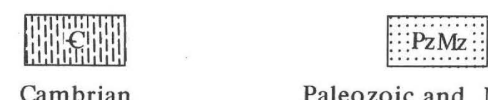

Paleozoic and Mesozoic

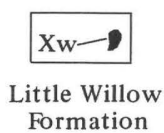


it, and in the Sheeprock, Dugway, Canyon, and Beaver Ranges further south (fig. 23). Except for rocks on one island in Great Salt Lake west of the autochthonous segment, those of all these exposures are allochthonous, and in the upper plates of thrusts of the Sevier orogenic belt. All the rocks are supracrustal and part of Precambrian Z. No Precambrian Y supracrustal rocks are visible, and with one minor exception, no crystalline basement; the extent of the older Precambrian rocks in the area, if they exist, is indeterminate.

Equivalents of the two relatively thin, unconformity-bounded Precambrian $\mathrm{Z}$ units of the autochthon (Mineral Fork and Mutual) occur in the allochthonous rocks, but here they are widely separated in a much thicker conformable sequence. In the well-known outcrops on the upper plate of the Willard thrust in the northern Wasatch Mountains, the sequence beneath the Cambrian is $13,000 \mathrm{ft}(4,000 \mathrm{~m})$ thick, but it reaches $20,000 \mathrm{ft}(6,100 \mathrm{~m})$ in the structurally more complex sequence near Pocatello, as deciphered by D. E. Trimble (Crittenden, Schaefer, Trimble, and Woodward, 1971, p. 582-594). Partial sequences preserved in the ranges farther south are thinner.

In the upper plate of the Willard thrust in the Wasatch Mountains the supracrustal sequence bottoms on a thin wedge of crystalline basement (not on Geologic Map, but see fig. 23), which has been dated by rubidium-strontium methods on muscovites as between 1,600 and 1,800 m.y. (Crittenden, McKee, and Peterman, 1971), or approximately correlative with the autochthonous Farmington Canyon Complex exposed to the south.

Tillite (diamictite) like that in the Mineral Fork occurs low in nearly all the sequences, and in the Pocatello sequence contains an interbedded member of greenstone flows and tuffs, reminiscent of the Irene Volcanics intercalated in the diamictites of the Windermere Group farther north. A unit lithically identical with the Mutual Formation of the autochthon occurs much higher, the intervening strata being shale and siltstone with one or more thick quartzite units and in places a thin limestone layer. The rocks above the Mutual equivalent are mainly quartzites, traditionally called Brigham, Tintic, or Prospect Mountain depending on locality and considered to be basal Cambrian. However, only their upper parts can be proved paleontologically to be of Cambrian age, and the lower parts may be Precambrian Z; these lower parts are now mostly given other formational names. A volcanic breccia in the Browns Hole Formation, between the Mutual and the upper quartzites, has yielded an argon-argon date on hornblende of 570 m.y. (Crittenden and Wallace, 1973, p. 128), which indicates that it lies close to the Precambrian-Cambrian boundary.

\section{SUPRACRUSTAL ROCKS OF UTAH-NEVADA BORDER}

To the west, near the border between Utah and Nevada, Precambrian Z supracrustal rocks reappear in various mountains, from the Pilot Range $150 \mathrm{mi}$ $(250 \mathrm{~km})$ southward to the southern Snake Range, and westward for $50 \mathrm{mi}(80 \mathrm{~km})$ into Nevada. They much resemble the supracrustal rocks just described, but are separated from them by a broad gap, mostly occupied by the Great Salt Lake Desert, and their structural setting differs. All of them lie in an infrastructure beneath the regional décollement mentioned earlier, and have been subjected to low- to medium-grade metamorphism during the Mesozoic orogenies.

The rocks are termed the McCoy Creek Group from a locality in the Schell Creek Mountains, Nevada, where there is a 9,000 -ft $(2,700 \mathrm{~m})$ sequence beneath the Cambrian Prospect Mountain Quartzite (Misch and Hazzard, 1962, p. 307-320). The group is nearly as thick in the Deep Creek Range, and 3,600 ft (1,100 m) of the upper part is preserved in the southern Snake Range. The rocks include several persistent quartzite units separated by units of argillite and siltstone, with a few minor layers of marble. The sequence in the Deep Creek Range, farther east than the rest, includes several horizons of "tillitic schist," originally a diamictite of sand and silt with widely dispersed dropstones up to boulder size, of granite, gneiss, and quartzite; it is the water-laid distal end of the tillites (diamictites) farther east in the Great Basin.

The lowest rocks exposed in the sequences are commonly the most strongly metamorphosed, but are conformable with those above, and no earlier basement emerges south of the Albion and Raft River Ranges (p. 48). The upper beds have a sharp boundary with the overlying Prospect Mountain Quartzite, but the succession is seemingly conformable from one to the other.

\section{SOUTHERN BASIN AND RANGE PROVINCE}

In the final section of this review the exposed Precambrian of the southwestern United States will be considered, from southern California $800 \mathrm{mi}(1,300 \mathrm{~km})$ eastward to western Texas, and $700 \mathrm{mi}(1,100 \mathrm{~km})$ or more north from the Mexican border. Although this large region is diverse in terms of modern morphology and Phanerozoic structure, its Precambrian rocks have a certain homogeneity that facilitates description. Moreover, the largest area of Precambrian outcrop and the most significant sequences are in Arizona, and these furnish standards with which the remainder can be compared.

The southern Basin and Range province is a terrain of block-faulted mountains and intervening lowlands and deserts, much like that of the eastern Great Basin 
treated in the previous section. Here, however, most of the drainage is exterior, leading into the Colorado River and its tributaries. In the lower "desert" region of southwestern Arizona and southeastern California, many of the block ranges have been so eroded that their original structural forms have been lost, and they stand as islands in a much broader sea of lowlands. On the other hand, in the "mountain" region of Arizona farther north, along the edge of the Colorado Plateau, the block ranges coalesce so that outcrops of Precambrian rocks are nearly continuous, except for outliers and downfaulted strips of Phanerozoic rocks. Included in this account are also the classic, long-known Precambrian rocks that form the lower walls of the Grand Canyon within the Colorado Plateau, and the Precambrian rocks of the Transverse Ranges of southern California, both lying in Phanerozoic morphological and tectonic settings different from the rest.

The most extensively exposed Precambrian rocks in much of the region, and especially in Arizona, are the crystalline basement of Precambrian X-paraschists, paragneisses, orthogneisses, and granites-in which are embedded a few younger plutons of Precambrian Y Lying on their deeply eroded surface, and preserved in smaller areas, are little-deformed supracrustal rocks of Precambrian Y, including such units as the Grand Canyon Supergroup and the Apache Group of Arizona. Younger supracrustal rocks of Precambrian Z form still smaller areas, mainly in southwestern Nevada and eastern California. As in the Southern Rocky Mountains and eastern Great Basin, no rocks of Precambrian $\mathrm{W}$ have been identified in the region, if indeed they ever existed.

\section{CRYSTALLINE BASEMENT OF ARIZONA (MAINLY PRECAMBRIAN X)}

In Arizona (and elsewhere in the southwestern United States) the crystalline basement is divided on the Geologic Map into metasedimentary rocks (X), orthogneiss and paragneiss $(\mathrm{Xm})$, and granitic rocks $(\mathrm{Xg}$, $\mathrm{Yg} 1$, and $\mathrm{Yg}_{2}$ ).

These units are modified from those of the Geologic Map of Arizona of 1969 as follows: Our unit X includes schist, greenstone, rhyolite, and Mazatzal Quartzite (units $\mathrm{p} \epsilon_{s c}, \mathrm{p} \epsilon_{\mathrm{gs}}$, p€ry, and $\mathrm{p} \Theta_{\mathrm{m}}$ of the Arizona Map); because of the small scale of the United States Map the metavolcanics are grouped with the metasediments. Our unit Xm includes Precambrian gneisses (p€gn), as well as so-called "Mesozoic" and "Cretaceous-Tertiary" gneisses ( Mkgn, TKgn), which are largely Precambrian in origin, but were reworked during Phanerozoic orogenies. Our units Xg, Yg1, and $\mathrm{Yg}_{2}$ are the granite, quartz monzonite, and quartz diorite of the Arizona
Map (p€gr), which we have subdivided according to their radiometric ages. The Precambrian diorite and pyroxenite ( $p \in d i, p-€ p y$ ) shown on the State Map are too small to be shown on the United States Map.

The metamorphic rocks of Arizona traditionally have been called the Vishnu Schist to the north in the Grand Canyon, the Yavapai Schist in the central region, and the Pinal Schist in the southeastern region, all supposedly more or less correlative. More information is available now on all these units, although the schists and gneisses of the desert region to the southwest remain poorly understood. Modern radiometric work indicates that all these metamorphic rocks and most of the granites which intrude them have Hudsonian ages between 1,650 and 1,850 m.y., thus placing them in the later part of Precambrian X, but they are not necessarily correlative, and some of them are clearly younger than others.

The Vishnu in the Grand Canyon includes the quartzose, micaceous Vishnu Schist (restricted) and the mafic Brahma Schist, the first derived from sediments, the second from volcanics; the whole forming an original sequence tens of thousands of feet thick. This was steeply folded along northeast axes, metamorphosed, and pervasively injected by the Zoroaster Granite (Maxson, 1961) (not separated on the map). The Zoroaster has yielded an age of 1,725 m.y. by uranium-lead methods on zircons, which indicates the minimum age of the whole assemblage (Pasteels and Silver, 1966), although dates as low as 1,390 m.y. have been obtained from it and the adjoining schists by rubidium-strontium methods (Giletti and Damon, 1961, p. 640).

The Pinal Schist of southeastern Arizona, as represented in the Dragoon quadrangle, is a similarly thick body, derived from original graywacke and slate with interbedded felsic and mafic volcanics, steeply folded along northeast axes, metamorphosed to greenschist or amphibolite grade, and intruded by granodiorite and granite (Cooper and Silver, 1964, p. 11-34). The rhyolites have yielded an age of 1,715 m.y. and the intrusive granodiorite an age of 1,615-1,630 m.y. by uraniumlead methods on zircons, suggesting that these rocks are somewhat younger than those in the Grand Canyon.

The Yavapai Schist and associated metamorphic rocks of central Arizona, exposed in broader, more continuous areas than the Vishnu and Pinal, are more varied. They have been deformed along northeasttrending axes and subjected to greenschist or low amphibolite grades of metamorphism, but original sedimentary and volcanic structures are commonly well preserved. Wilson (1939, p. 1117-1129) was one of the first to demonstrate that the Yavapai rocks are divisible into distinctive, mappable formations of which he named nearly a dozen that he correlated between dis- 
tricts. His original classification has been amplified and emended by further mapping, and by radiometric dating that has shown more clearly the relative ages of the units.

The type Yavapai area is in the center of the State near Prescott and Jerome, where the sequence includes the Ash Creek and Big Bug Groups, each about 20,000 ft $(6,100 \mathrm{~m})$ thick, both composed of felsic and mafic volcanic and volcaniclastic rocks, and interbedded sediments (Anderson, 1968, p. 14-17) (fig. 24). They are separated from each other by granitic plutons and by a major north-south strike-slip fault, but radiometric dating by uranium-lead methods on zircons indicates that the Ash Creek is the older, the collective age of the two groups being between 1,775 and 1,820 m.y. (Anderson and others, 1971). On this basis the two are considered to represent a time-stratigraphic unit, and are called Yavapai Series. In separate fault blocks in the same area the Texas Gulch Formation lies with basal conglomerate on the Brady Butte Granodiorite. Formerly the Texas Gulch was supposed to represent the base of the Yavapai sequence, but the granodiorite has an age of 1,770 m.y., so that the Texas Gulch is the youngest rock in the district, and is excluded from the Yavapai Series as now defined.

In the Mazatzal Mountains farther east, which were studied in most detail by Wilson, the Yavapai rocks include several units of greenstone, rhyolite, and volcaniclastic sediments which are so complexly faulted that their original sequence is conjectural. Only the Red Rock Rhyolite is in stratigraphic continuity with the uppermost rocks, the prominent, well-bedded Mazatzal Quartzite and the minor underlying Maverick Shale and Deadman Quartzite (Wilson, 1939, p. 1134-1137). The Red Rock has been dated by uranium-lead methods at 1,715 m.y. (Silver, 1965), suggesting that a considerable part of the rocks in the Mazatzal Mountains is younger than the Yavapai Series as now restricted.

In the Diamond Butte area a little farther east, on the north flank of the Sierra Ancha, Gastil (1958) has mapped in detail rocks like those in the Mazatzal Mountains, forming a $20,000-\mathrm{ft}(6,100 \mathrm{~m})$ sequence without top or base, divided into eight named formations, mainly volcanic or volcaniclastic. The apparent equivalent of the Mazatzal Quartzite (Houden Formation) is near the middle, and is followed by younger volcanics apparently unrepresented farther west.

Other areas of Yavapai-type rocks in central Arizona could be mentioned (see, for example, Livingston and Damon, 1968, p. 765-769), but the above are sufficient to indicate their features, their complexities, and their problems in correlation; further studies are needed before the rocks of the whole area can be integrated into a single picture.
The metamorphic rocks of central Arizona are extensively invaded by synkinematic and postkinematic granitic plutons $(\mathrm{Xg})$. In the Prescott-Jerome area and farther west these have uranium-lead ages between 1,760 and 1,775 m.y., suggesting that their intrusion was partly contemporaneous with the later volcanism of the Yavapai Series. Farther east and southeast, as far as the Pinal Schist area mentioned earlier, similar granites are slightly younger, with ages of about 1,660 m.y. A later suite of granitic rocks ( $\left.\mathrm{Yg}_{1}\right)$, typified by the Ruin and Oracle Granites of the districts between the Sierra Ancha and Tucson, has been dated as between 1,420 and 1,460 m.y. by various methods, and a single body in Weaver Mountain south of Prescott (Yg2) has yielded a uranium-lead age of 1,000 m.y.

The deformation, metamorphism, and plutonism of the crystalline basement of central Arizona (and elsewhere in the southern Basin and Range province) preceded the accumulation of the Precambrian Y supracrustal rocks described below, which lie on its truncated, deeply eroded surface. This represents the "Mazatzal Revolution" (orogeny) of Wilson (1939, p. 1161). For a time this orogeny was thought to have an Elsonian age of 1,350-1,550 m.y. (Giletti and Damon, 1961, p. 642), but this interpretation was based on insufficient sampling, mainly of postorogenic plutons; its true Hudsonian date is shown by more complete studies to lie between 1,660 and 1,715 m.y. (Wasserburg and Lanphere, 1965, p. 736; Silver, 1965).

\section{CRYSTALLINE BASEMENT OF SOUTHERN CALIFORNIA} (MAINLY PRECAMBRIAN X)

Crystalline basement like that in Arizona, and again dominated by Hudsonian dates, is exposed in many of the ranges in southern California, from Death Valley on the north, southward through the Mojave Desert, into the Transverse Ranges. In this region, the basement rocks have been more involved in and overprinted by the effects of Phanerozoic orogenies than those farther east.

In southern Death Valley Precambrian crystalline basement forms the prominent, rugged part of the Black Mountains on the eastern side, and inliers in the later Precambrian supracrustal rocks (Y and Z) of the Panamint Range on the western side. In the Panamint area, earlier paragneisses and orthogneisses are cut by intrusives which have yielded Hudsonian dates of $1,720-1,780$ m.y. by uranium-lead methods on zircons, indicating the minimum age of the whole complex (Silver and others, 1962). Rubidium-strontium and potassium-argon ratios in the rocks have been so disturbed by Mesozoic metamorphism that they give unreliable results (Wasserburg and others, 1964, p. 4400). Smaller, more dispersed outcrops of basement occur 


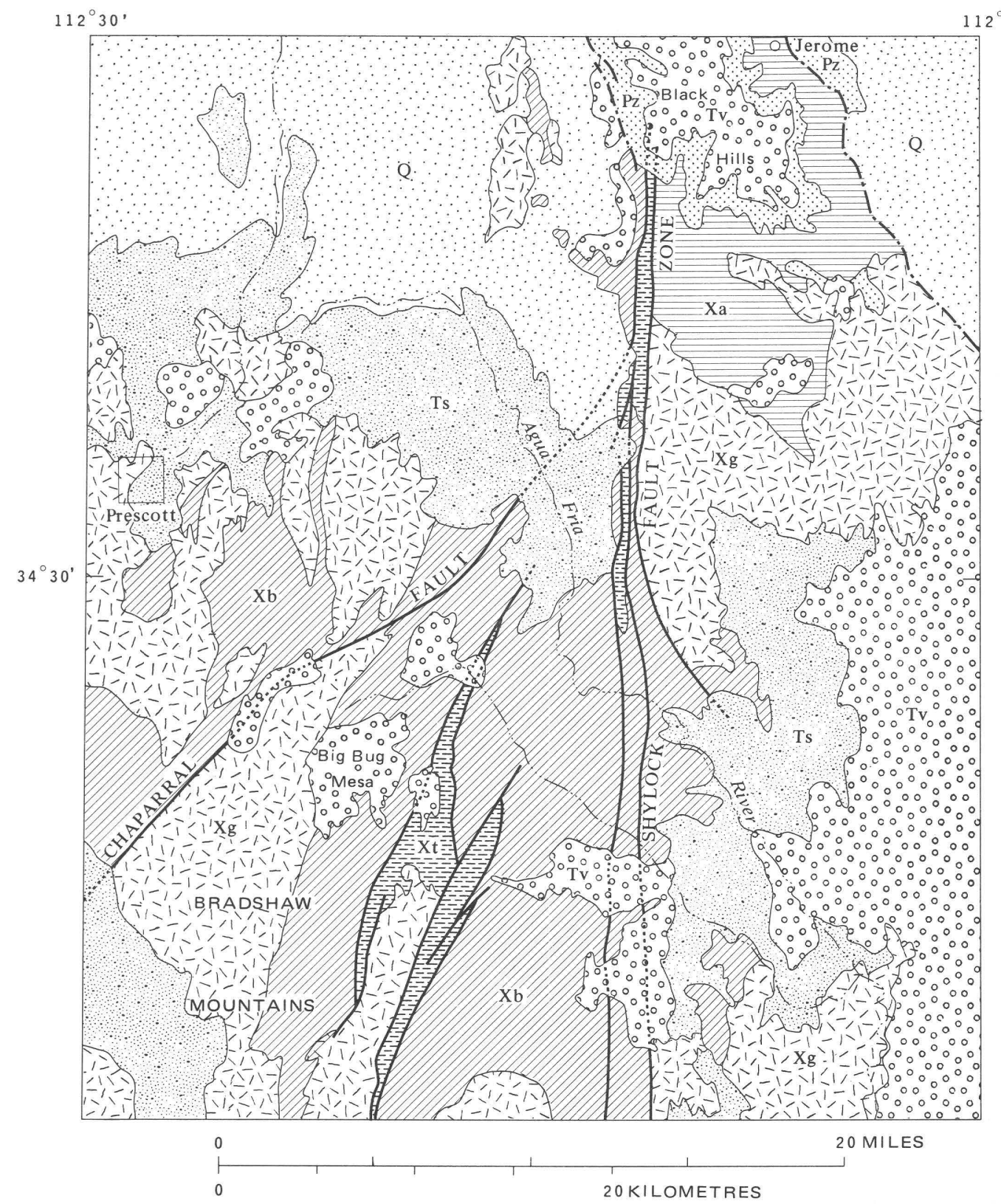

EXPLANATION

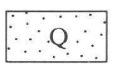

Quaternary

intermontane deposits

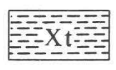

Texas Gulch Formation Unconformable on granodiorite

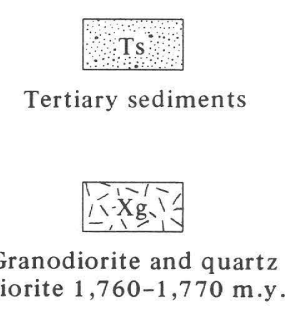

diorite 1,760-1,770 m.y.

Phanerozoic faults

$112^{\circ}$ 
farther south in the Mojave Desert. Dating of these rocks by potassium-argon and rubidium-strontium methods indicates Hudsonian metamorphism of the country rock about 1,650 m.y. ago, but a few of the plutons (as in the Marble Mountains) have an Elsonian age of about 1,400 m.y. (Lanphere, 1964, p. 396-397); these have not been separated from the Precambrian X rocks on the Geologic Map.

Of greater interest than these are the Precambrian rocks of the Transverse Ranges to the southwest, which are nearer the Pacific Coast than any others in the United States. They are part of the crystalline complex of the rugged San Gabriel and San Bernardino Mountains, whose peaks project to altitudes of $10,000 \mathrm{ft}(3,000$ $\mathrm{m})$ or more. The mountains are upthrust blocks within the network of strike-slip faults of coastal California, and lie on opposite sides of the master San Andreas fault (Dibblee, 1968).

The crystalline complexes of the two ranges exhibit a remarkable array of metamorphic and plutonic rocks of diverse ages, including upper Mesozoic eugeosynclinal rocks (Pelona Schist, u Mke), Paleozoic miogeosynclinal quartzites and marbles (uP), Mesozoic granitic plutons with ages of 75-90 m.y. and 160-170 m.y. (Kg), and the upper Paleozoic Mount Lowe Granodiorite with an age of 220 m.y. ( $\mathrm{Bg} 3$ ). These lie in a Precambrian matrix, now preserved only in shreds and patches, or orthogneiss and paragneiss of granulite facies $(\mathrm{Xm})$, into which a large body of anorthosite ( $\mathrm{Ya}$ ) has been intruded in the western part of the San Gabriel Mountains (Crowell and Walker, 1962, p. 242-261).

South of the Tranverse Ranges, across the Los Angeles Basin and San Gorgonio Pass are other crystalline massifs of the Peninsular Ranges, but their rocks are curiously different, and are all Paleozoic and Mesozoic in origin.

In the Transverse Ranges, geologic studies and radiometric dating of the Precambrian rocks (especially by uranium-lead methods on zircons) indicate a complex structural and metamorphic history, during both Precambrian time and later (Silver and others, 1963; Silver, 1971). Supracrustal sedimentary and volcanic rocks accumulated between 1,680-1,750 m.y. ago, and were deformed and mezamorphosed to amphibolite grade. They were invaded by granodiorite and quartz monzonite 1,650-1,680 m.y. ago, and the whole was subjected to a major orogeny 1,425-1,450 m.y. ago that refolded the rocks and raised them to granulite metamorphic grade. At about 1,220 m.y. ago the body of anorthosite and associated gabbro and syenite was intruded into the complex; there were no further Precambrian events, but the anorthosite was greatly disturbed and sheared during the Phanerozoic (Carter and Silver, 1971).

The diverse Precambrian events in the crystalline rocks of the Transverse Ranges contrast markedly with the simpler events in the regions to the east and north, where there was merely a Hudsonian metamorphism and plutonism, and a rare Elsonian plutonism. The contrast lends credence to the interpretation derived from geological evidence that the rocks of these ranges are far away from their original positions, whence they have been transported by strike-slip movements along the San Andreas and related faults, into the foreign environment of the Pacific border region. Traces of similar rocks occur in the Orocopia Mountains and nearby ranges northeast of the Salton Sea (Crowell and Walker, 1962, p. 222-242), but even these are merely in wedges in the broader fault network. The original sites of all these rocks are still farther southeast, in some region as yet unidentified.

\section{SUPRACRUSTAL ROCKS IN ARIZONA (MAINLY PRECAMBRIAN Y)}

Lying on the truncated and deeply eroded edges of the crystalline basement just described, especially northeastward toward the cratonic Colorado Plateau, are unmetamorphosed and only lightly deformed supracrustal sedimentary rocks, with minor interbedded lavas and intrusive diabase. These are shown on the Geologic Map of Arizona of 1969 as Grand Canyon Series, p€g; Apache Group, p€a; Troy Quartzite, p€t; and diabase, p€db. On the Geologic Map of the United States all these rocks, including the diabase but excluding the Chuar Group at the eastern end of the Grand Canyon, are grouped together as unit Y. The Chuar, for reasons indicated later, is labeled $\mathrm{Z}$.

The supracrustal rocks are exemplified especially by the well-known Grand Canyon Supergroup exposed in the depths of the Grand Canyon, but the Apache Group and Troy Quartzite farther south in Arizona are very much like it and probably correlative in part. As with the Belt Supergroup of the Northern Rocky Mountains, their fresh appearance belies their ancient age, leading to a first impression that they are early Paleozoic-an impression dispelled early in the Grand Canyon by Walcott (1895, p. 313-314), but which persisted much later in central Arizona, until disproved by Darton (1925, p. 34-36).

In the frequently visited, prominent exposures in the main segment of the Grand Canyon, the lower part of the Grand Canyon supergroup (Unkar Group) is tilted, block-faulted, and truncated by the flat-lying Middle Cambrian Tapeats Sandstone (fig. 25). The upper part (Chuar Group) in the seldom visited eastern alcoves of the canyon is less faulted and synclinally downwarped. Some of the faults were displaced only during the Precambrian, but others were reactivated later and offset the Paleozoic rocks by varying amounts. The most spectacular example is the Butte fault in the eastern part of 

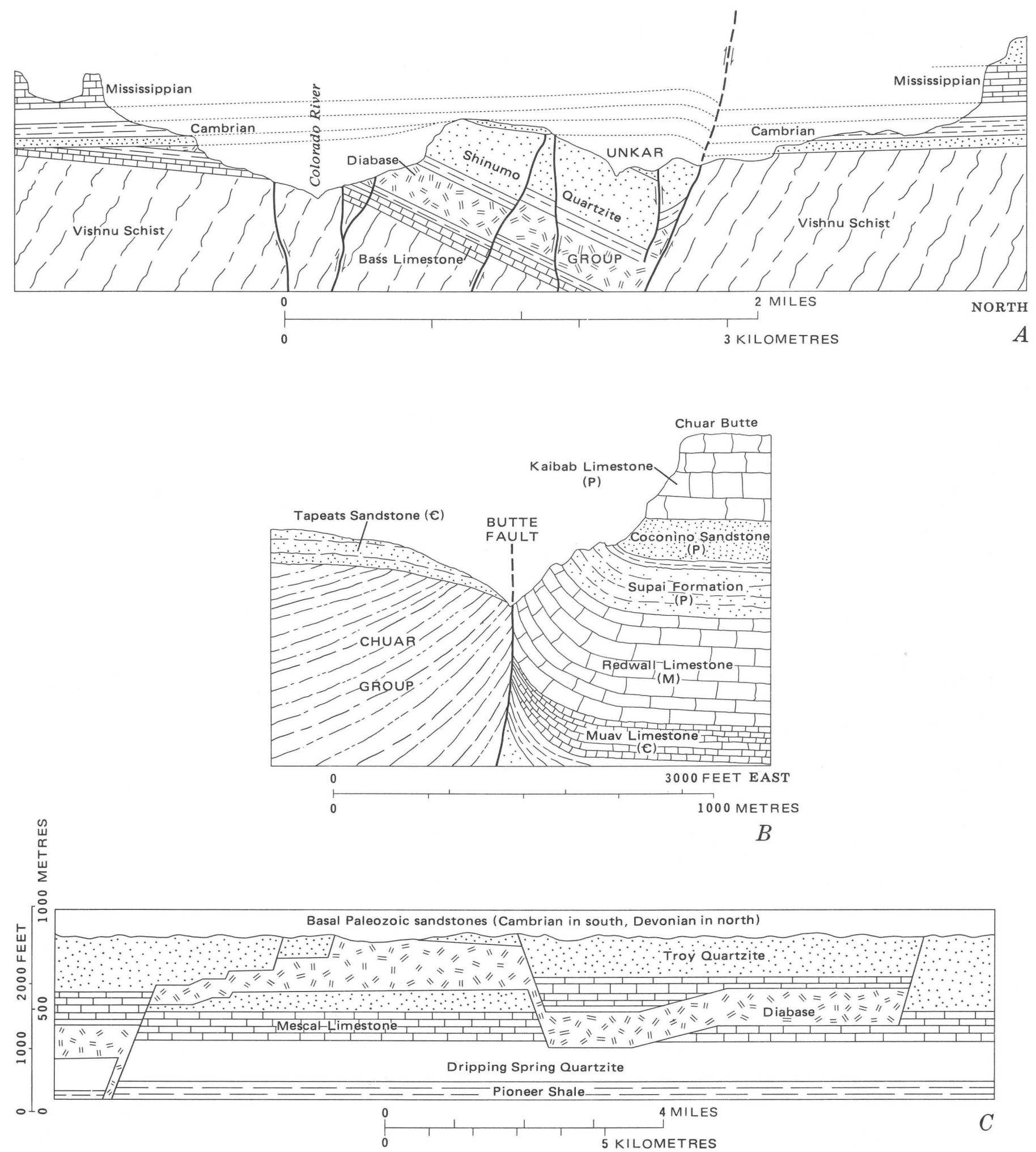

Figure 25.-A, Section showing Vishnu Schist and Unkar Group (Precambrian X and Y) in the Shinumo area, Grand Canyon, northern Arizona, and the truncation of their block-faulted structure by Cambrian deposits. Note, however, that the major fault on the right underwent recurrent reversed displacement after Paleozoic time. After Noble (1914, section $\left.B-B^{\prime}\right)$. $B$, Section of Butte fault in eastern Grand Canyon, Ariz., showing Precambrian downthrow to the left and post-Paleozoic downthrow to the right, each accompanied by steep dragging of the beds. After Walcott (1889, p. 53). C, Idealized section, showing disruption and distention of Apache Group and Troy Quartzite by sills and dikes of intrusive diabase. Based on outcrops in the Sierra Ancha and nearby localities, central Arizona. After Shride (1967, p. 67). 
the canyon, which was downthrown $5,000 \mathrm{ft}(1,500 \mathrm{~m})$ to the west in Precambrian time and 2,700 ft $(820 \mathrm{~m})$ to the east after Paleozoic time, each displacement being accompanied by steep dragging of the beds (Walcott, 1889) (fig. 25). The Apache Group and Troy Quartzite were little disturbed during Precambrian time, except for profuse injection of diabase sills and connecting dikes that have much disrupted and greatly distended the sequence (fig. 25). Along the Colorado Plateau margin, as in the Sierra Ancha, they are almost as little disturbed by Phanerozoic movements as in the Grand Canyon, but farther southwest they share the complex block faulting of the succeeding Paleozoic strata.

The supracrustal rocks in the Grand Canyon and central Arizona are divisible into persistent, distinctive formations, which are listed in table 4. The Apache Group and Troy Quartzite are obvious equivalents of the Unkar Group and contain identical rocks, but the order of the lithic units is strangely different in the two areas. The Bass Limestone is nearly at the base of the Unkar sequence and the Mescal Limestone is a thousand feet $(300 \mathrm{~m})$ or more above the base of the Apache. The red Hakatai Shale is above the Bass and the red Pioneer Shale is below the Mescal. The Troy Quartzite is at the top of the central Arizona sequence and the Shinumo Quartzite is beneath thick higher formations of the Unkar Group. Each set of formations persists within its own area, and the reasons for the reversals from one area to the other are not apparent. The differences in thickness of the sequences in the two areas are also of interest; the Apache and Troy are less than half as thick as the Unkar Group. The first two units may be a shelf or platform facies, farther away from the center of the depositional basin than the Unkar.

The Troy Quartzite has been poorly understood until recently (Shride, 1967, p. 44-45); its full thickness and subdivisions could only be deciphered from detailed work, which involved untangling the structure produced by the many diabase sills (fig. 21). Even after the Precambrian age of the underlying Apache Group was established, the Troy was long considered to be partly or wholly of Cambrian age, and equivalent to the Middle Cambrian Bolsa Quartzite. Actually, the Troy is overlain unconformably by the Bolsa, or by sandy phases of the succeeding Cambrian Abrigo Limestone and Devonian Martin Limestone (Krieger, 1968). Even though the Precambrian quartzites are everywhere overlain by Paleozoic sandstones and quartzites, the Troy is intruded by diabase and the higher strata are not; their basal beds frequently contain diabase debris, including cobbles and boulders in a few places.

Both the Mescal Limestone and Bass Limestone contain stromatolites at several levels; those in the Mescal
TABLE 4.-Precambrian supracrustal rocks of Arizona

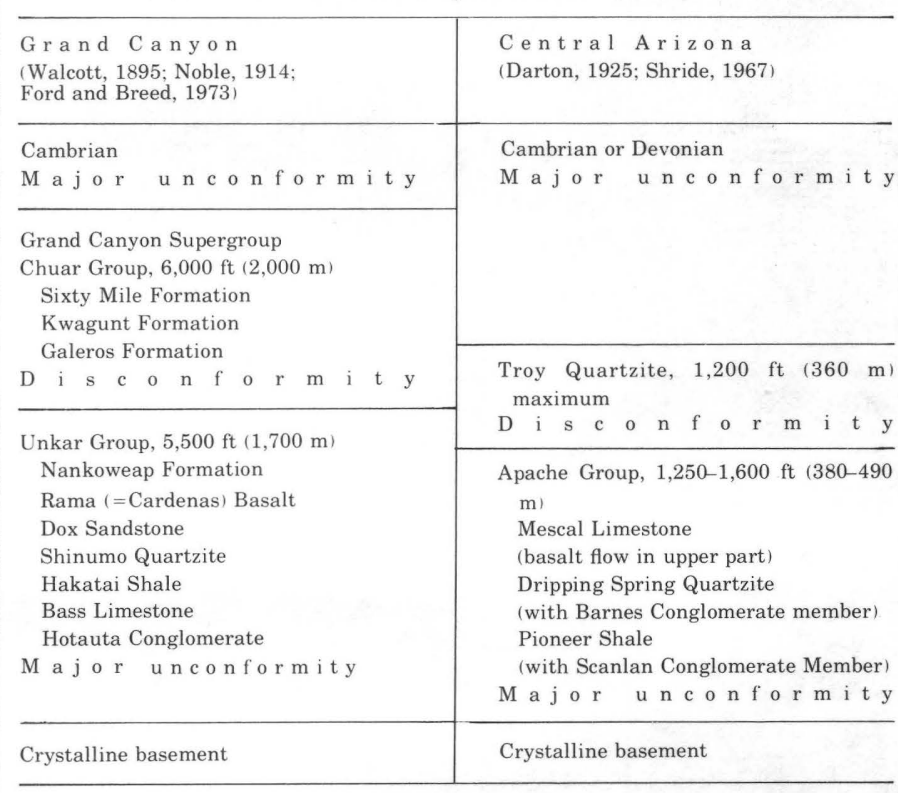

are comparable to a lower Middle Riphean form and to a Middle Riphean to Vendian form of the sequences in the Soviet Union (Cloud and Semikhatov, 1969, p. 1031). Other fossils have been reported in the Arizona supracrustal rocks, but nearly all of them are inorganic sedimentary structures.

Diabase sills in the Apache Group and Troy Quartzite of the Sierra Ancha have been dated by uranium-lead and potassium-argon methods at $1,150-1,200$ m.y. (Silver, 1960; Livingston and Damon, 1968, p. 769). The Apache and Troy are older than the diabase and younger than the 1,420-1,460-m.y.-old granitic rocks (Yg1) in the underlying basement (p. 64). Both the diabase sills in the Unkar Group and the Rama (= Cardenas) lavas near the top of the group yield rubidium-strontium ages of about 1,100 m.y.; potassium-argon ages from the same rocks of $800-900$ m.y. suggest a later heating event (McKee and Noble, 1974).

The Chuar Group, or upper unit of the Grand Canyon Supergroup, is rather different from the supracrustal rocks so far considered. It is a thick body of varicolored argillites, with thin stromatolite-bearing limestones at a dozen or so levels, and occasional beds of chert, oolite, and sandstone (Ford and Breed, 1973). Shales in the upper part of the group contain the small circular carbonaceous structures Chuaria, once thought to be primitive brachiopods, but now interpreted as crushed spheres of microplanktonic algae (Ford and Breed, 1972). The dating of the preceding Rama (= Cardenas) lava shows that the Chuar is younger than 1,100 m.y., so that it is either very late Precambrian Y, or even a part of Precambrian Z. On the Geologic Map it is 
speculatively indicated as $\mathrm{Z}$, although this is by no means proved.

\section{PAHRUMP GROUP OF EASTERN CALIFORNIA (PRECAMBRIAN Y AND Z)}

Supracrustal rocks, in part like those in Arizona, reappear in the southern part of the Death Valley area of eastern California, where they form the Pahrump Group (labeled Y on the Geologic Map, although the upper part probably includes rocks of Precambrian Z, as indicated below). The group is preserved in a belt extending $80 \mathrm{mi}(130 \mathrm{~km})$ northwestward from the Kingston Range east of Death Valley to the Panamint Range west of it, northeast and southwest of which younger strata lie directly on the crystalline basement (Xm) (Wright and Troxel, 1967, p. 938-939).

The group is a package of supracrustal rocks partitioned by unconformities from the older and younger Precambrian below and above, but inhomogeneous internally, and with considerable lateral variation. It is divisible into the Crystal Spring Formation, Beck Spring Dolomite, and Kingston Peak Formation, which total $5,000 \mathrm{ft}(1,500 \mathrm{~m})$ thick in the Kingston Range, but reach up to $7,000-8,000 \mathrm{ft}(2,100-2,440 \mathrm{~m})$ farther west (Wright, 1968, p. 9-10).

The Crystal Spring Formation lies on the basement, is 3,000-4,000 ft (900-1,200 m) thick, and is formed of lithic units much like those in the Unkar and Apache Groups of Arizona, including quartzites and shales below and above, and medial limestones or dolomites with associated chert. It is extensively invaded by diabase sills, one of which has widely altered the medial carbonates to commercial grades of talc. The Beck Spring Dolomite is a massive body that attains $1,000 \mathrm{ft}$ $(300 \mathrm{~m})$ in the east, but which wedges out westward and southwestward.

The upper unit of the group, or Kingston Peak Formation, differs from any of the supracrustal rocks to the east in Arizona. It is a body $1,000-2,500 \mathrm{ft}(300-760 \mathrm{~m})$ thick of conglomerate or diamictite and associated shaly or sandy layers, some of which contain widely dispersed dropstones. The diamictites contain small to large clasts of crystalline basement, Crystal Spring and Beck Spring sediments, and diabase like that intruding the Crystal Spring Formation. Within the area of exposure the Kingston Peak is slightly unconformable on the underlying parts of the group, but they must have been sharply eroded elsewhere to provide the clasts in the diamictites. The formation is angularly truncated northeastward by the Noonday Dolomite at the base of the main Precambrian $\mathrm{Z}$ sequence, but elsewhere the discordance is slight or nonevident.

Stromatolites occur in both the Crystal Spring and Beck Spring carbonates; those in the former are com- parable to forms in the Middle Riphean to lower Upper Riphean of the Soviet Union. Stromatolites in the Beck Spring are associated with eucaryotic nannofossils, indicating the very early existence here of precursors of the metazoans (Cloud and others, 1969). No reliable radiometric dates have been obtained on the rocks of the Pahrump Group or the diabase intrusives in the Crystal Spring, but the two lower formations are quite comparable to the Unkar Group, the Apache Group, and the Troy Quartzite in Arizona, and like them may have an age of about $1,100-1,420$ m.y.

The diamictites of the Kingston Peak Formation have much the same character as the diamictites farther north in the Cordilleran province (Mineral Fork, Toby, etc.), and likewise may be of direct or indirect glacial derivation (Johnson, 1957, p. 368-369; Crittenden and others, 1972 , p. 339). Like the comparable deposits farther north, they are probably to be assigned to the early part of Precambrian Z; here, however, they are unconformable with the main body of Precambrian $\mathrm{Z}$ above.

PRECAMBRIAN OF WESTERN TEXAS (MAINLY PRECAMBRIAN Y)

In the Basin and Range province east of southern Arizona, in southwestern New Mexico, and western Texas, small outcrops of Precambrian rocks occur in the structurally higher parts of the ranges, in a terrain otherwise dominated by Phanerozoic rocks. Those in New Mexico are mainly Precambrian X metamorphic and plutonic rocks, but those in Texas are more varied and of younger ages, including supracrustal rocks of Precambrian Y that are $250 \mathrm{mi}(400 \mathrm{~km})$ or more east of those in Arizona.

In Texas, Precambrian is exposed in the Franklin Mountains north of El Paso at the extreme western end of the State, in the Van Horn area $100 \mathrm{mi}(160 \mathrm{~km})$ farther southeast, and in two small patches in the intervening area. Near Van Horn, Precambrian rocks (shown on the Geologic Map as X, Y, and Z) emerge in several fault blocks in an area of about $225 \mathrm{mi}^{2}(580$ $\mathrm{km}^{2}$ ) sometimes rather inappropriately called the "Van Horn dome" (fig. 26). In the Franklin Mountains they are almost as varied as at Van Horn (although marked only as Yg2 on the Geologic Map), but are exposed only in a narrow $14-\mathrm{mi}(23 \mathrm{~km})$ strip along the east face of the range. The rock sequences in the two areas are shown in table 5.

In western Texas and southeastern New Mexico the next youngest unit above the Precambrian is the Bliss Sandstone of latest Cambrian or earliest Ordovician age, but this is not preserved everywhere, and elsewhere the Precambrian is followed directly by upper Paleozoic or even Cretaceous strata. In the 
Franklin Mountains the Precambrian supracrustal $\mid$ sive, yet the inclination of their strata conforms closely rocks are disrupted by the Precambrian granitic intru- $\mid$ to that of the overlying Paleozoic. In the Van Horn area
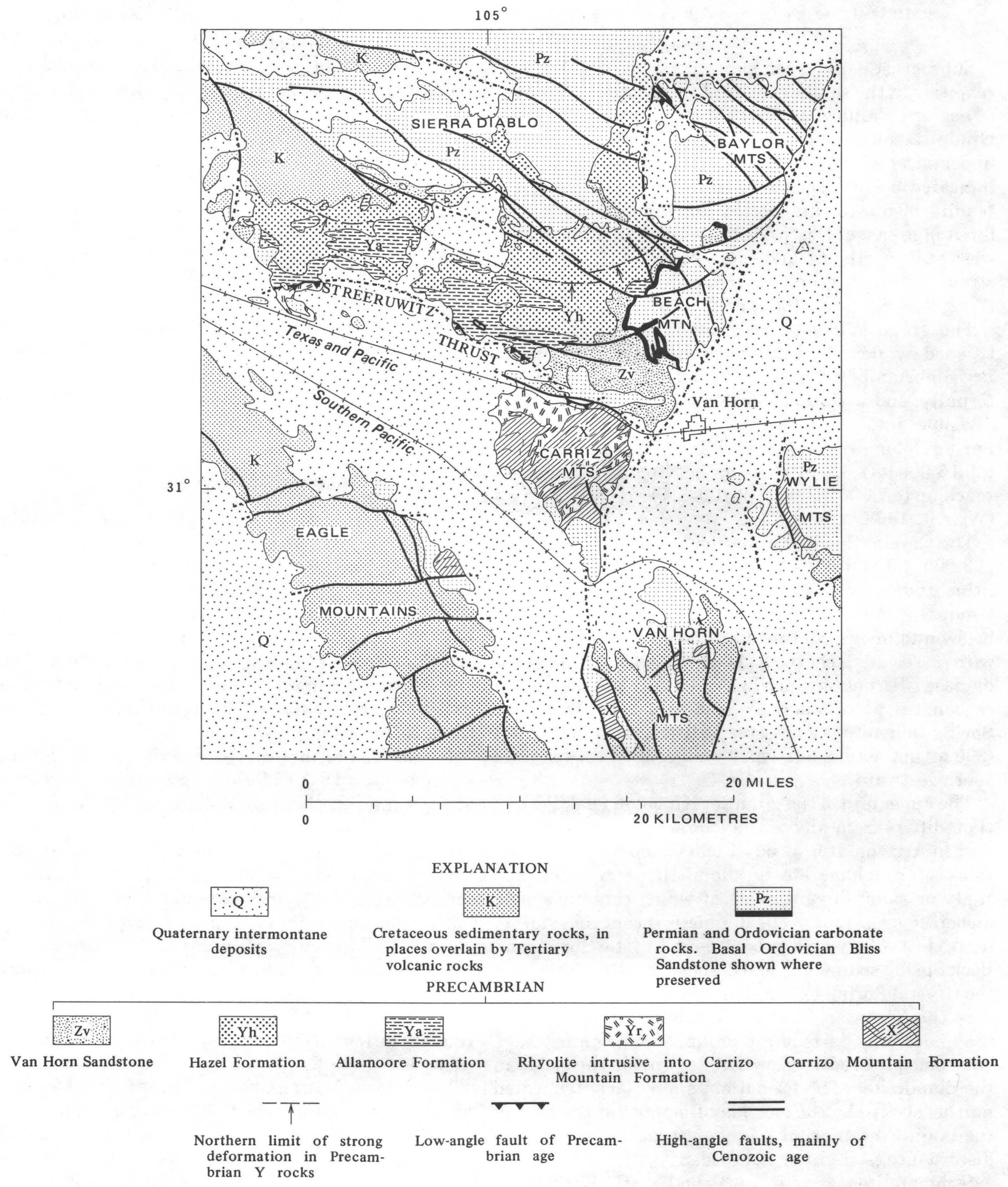

Figure 26.-Map of Van Horn area, west Texas, showing Precambrian rocks, and their relations to surrounding Phanerozoic rocks. Compiled from King and Flawn (1953), and other sources. 


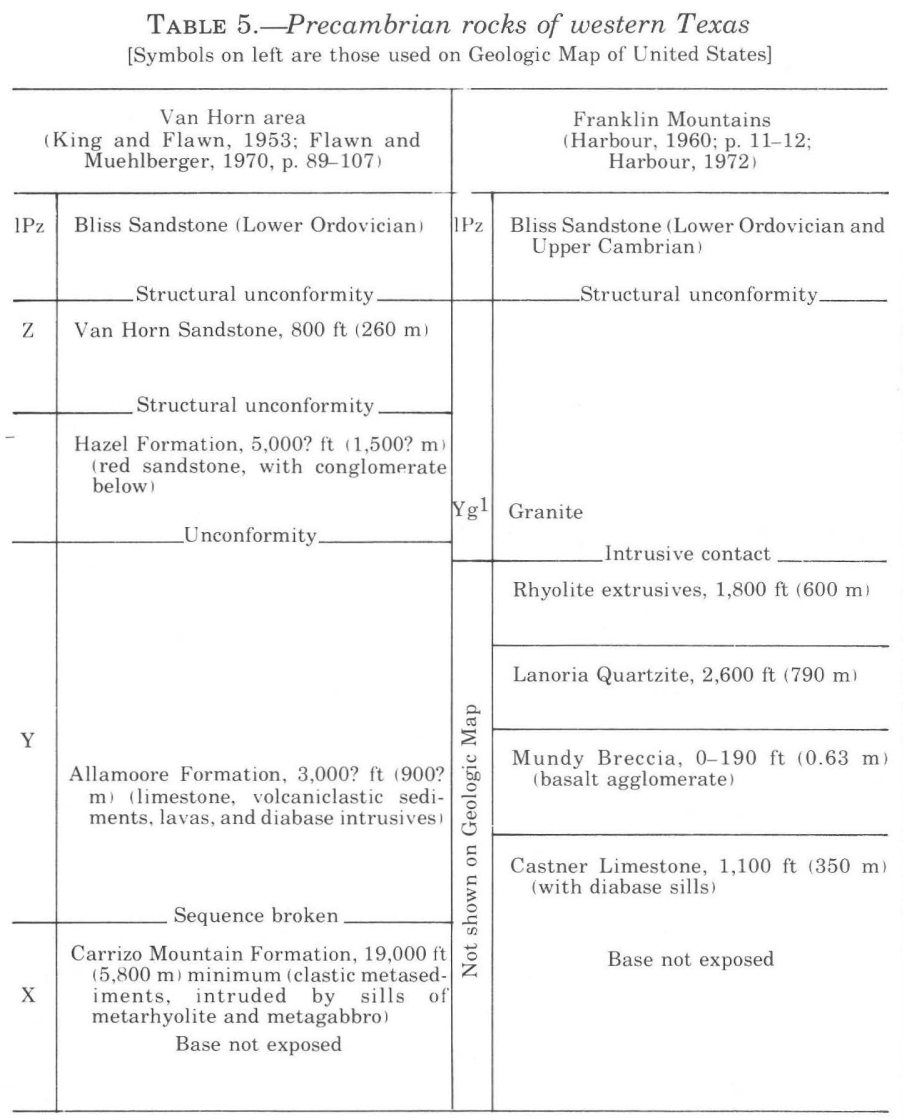

all the Precambrian supracrustal rocks except the Van Horn Sandstone have been orogenically deformed in what has been termed the "Van Horn mobile belt" (Flawn, 1956, p. 32)-in contrast to those in the Franklin Mountains and those farther west that have been discussed earlier.

Within the mobile belt the Carrizo Mountain Formation is to the south and is followed successively northward by the Allamoore and Hazel Formations; the Van Horn Sandstone is a postorogenic deposit that lies indiscriminately on the rest. However, the Carrizo Mountain metasediments are not in contact with the Allamoore, but are separated from it by large intrusive bodies of metarhyolite which adjoin the Allamoore along a major low-angle fault, the Streeruwitz thrust. For about $3 \mathrm{mi}$ $(5 \mathrm{~km})$ north of the thrust trace the Allamoore and Hazel are strongly folded and thrust, but the deformation decreases rapidly beyond, and the Hazel in its northern exposures is nearly horizontal (fig. 27).

Metamorphism also decreases northward. The Carrizo Mountain Formation is of amphibolite grade in its southern exposures and contains much pegmatite; in its northern exposures it is of greenschist grade but it has been retrograded near the Streeruwitz thrust, and the rhyolite along the thrust has been converted to mylonite with conspicuous south-plunging lineation. The Allamoore Formation has been hydrothermally altered to jasperoid close to the thrust, and some of the limestone layers farther north have been selectively converted to talc by the same process; blue alkali amphibole and white asbestiform amphibole (richterite) occur in places (Rohrbacher, 1973, p. 6-13). Elsewhere in the disturbed belt neither the Allamoore nor the Hazel Formation are much metamorphosed, although some of their weaker layers show marked slaty cleavage.

Traditionally, the Carrizo Mountain Formation has been considered the oldest unit in the sequence, and on the Geologic Map this presumed age has been expressed speculatively by classifying it as Precambrian X. However, there is little confirmation of this in the known geologic and radiometric data; alternatively, the Carrizo Mountain may originally have been a conformable downward sequence beneath the Allamoore, or it might have been a more internal, eugeosynclinal facies of the Allamoore (Flawn and Muehlberger, 1970, p. 105-106). The Streeruwitz thrust might even have been a major suture in the Precambrian terrane that juxtaposed contrasting sequences which were originally far apart, but exposures are too limited for proof of this possibility.

The limestone of the Allamoore is identical with that of the Castner in the Franklin Mountains, and both contain stromatolitic layers. Both, in turn, strikingly resemble the limestones of the Mescal and Bass in Arizona and the Crystal Spring in California. The talc deposits in the Allamoore, like those in the Crystal Spring, are commercially productive, and are being mined on a large scale (Rohrbacher, 1973, p. 1).

The Hazel and Allamoore Formations are intricately folded together in the deformed belt north of the Streeruwitz thrust, but the two are mostly separated by zones of shearing and thrusting, so that their original contact is seldom preserved. It must have been unconformable, because the lower part of the Hazel is a conglomerate composed largely of clasts derived from the Allamoore: limestones (including a few marmorized pieces), and the lavas and mafic intrusives. Besides these, the conglomerate contains a few clasts of red granite and rhyolite porphyry like those in the Franklin Mountains and elsewhere north of the Van Horn area, implying that the Hazel is not only younger than these, but younger than all the supracrustal formations in the Franklin Mountains.

The Hazel Formation is a very thick deposit of two contrasting facies: coarse, poorly sorted, poorly rounded conglomerates below, and fine-grained, almost silty, thinly laminated red sandstones above. Passage from one facies to the other is by interbedding, yet they are seldom intergradational-few of the conglomerates have a red sandy matrix, and few of the sandstones are pebbly. It is tempting to compare these conglomerates with the diamictites of the Kingston Peak Formation of 


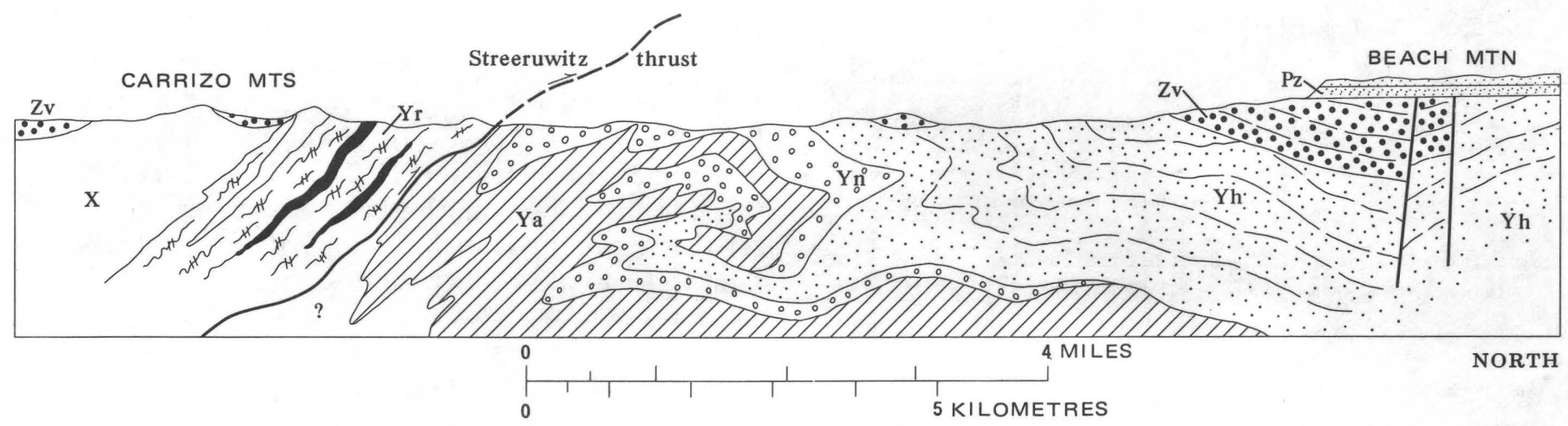

Figure 27.-Synoptic section across Precambrian rocks of Van Horn area, west Texas, showing structural relations of the different units and their implications in the Precambrian history of the area. Letter symbols are the same as those on fig. 26; black lenses in unit Yr are mafic intrusives. After King (in King and Flawn, 1953, p. 104).

California, but verification requires further field review.

Whatever the relations between the Allamoore and Hazel may have been, the climactic orogeny in the Van Horn mobile belt came later, after the deposition of the Hazel Formation. This orogeny resulted in the northward emplacement of the Carrizo Mountain Formation and its intrusive rhyolites along the Streeruwitz thrust, their retrograde metamorphism, and the deformation of the Allamoore and Hazel immediately to the north. By this deformation the Allamoore was thrown into northfacing recumbent folds and thrust over the Hazel. Besides these fold and thrust structures there are some curious patches farther north of highly crumpled Allamoore resting on nearly flat-lying Hazel that may have been emplaced during the orogeny as detached gravity slides.

Radiometric data on the west Texas Precambrian are incomplete, but partly clarify some of its geologic and orogenic problems (Wasserburg and others, 1962, p. 4023-4031). Radiometric determinations by potassium-argon, rubidium-strontium, and a few by uranium-lead methods have been made on the granites of the Franklin Mountains and the nearby Hueco Mountains, on rhyolites from the Pump Station Hills north of the Van Horn area, and on metarhyolites and pegmatites in the Carrizo Mountain Formation; all yield dates of about 1,100 m.y.

The dates define a widespread igneous event that is younger than any of the supracrustal rocks of the Franklin Mountains, and by implication younger than the Allamoore Formation of the Van Horn area. On the other hand, the event must have been older than the Hazel Formation, which contains a few clasts of the felsic igneous rocks, and it is therefore also earlier than the climactic orogeny of the Van Horn mobile belt.

The 1,100 m.y. dates are comparable to the dates determined on mafic intrusives in the Precambrian Y supracrustal rocks of Arizona, and they are also com- parable to the dates obtained on the infracrustal metamorphic and plutonic rocks of the Llano uplift, 300 $\mathrm{mi}(480 \mathrm{~km})$ to the east in central Texas (p. 42); similar dates have been obtained even nearer at hand from basement rocks of the "Texas craton" that have been drilled into west of the Llano uplift (Wasserburg and others, 1962, p. 4035-4036). The west Texas region thus marks the closest approach in the western United States of Precambrian Y supracrustal rocks to infracrustal rocks of the Grenvillian orogenic belt. The Van Horn mobile belt exposed in the Van Horn area is a tantalizingly small segment of what must be a major tectonic feature of the Precambrian in this part of North America, but one whose further extent and trend are unknown.

The succeeding Van Horn Sandstone is postorogenic, and lies with right-angled unconformity on all the earlier Precambrian formations; it is a red, arkosic, coarse, conglomeratic, continental deposit, probably laid down on compound alluvial fans that were largely fed from highlands to the north (McGowen and Groat, 1971). Its conglomerates contain clasts of the Allamoore and Hazel and of the mylonitized rhyolites from the upper plate of the Streeruwitz thrust to the south. However, the most prominent components are rounded cobbles and boulders of red granite and rhyolite porphyry like those exposed in the Precambrian areas to the northwest. The Van Horn is tilted at low angles in various directions rather than folded, and it was block-faulted and beveled before the basal Ordovician Bliss Sandstone was deposited on it. In older reports the formation was classed as Cambrian, but it is quite unlike any Cambrian elsewhere in the Southwestern States, and is almost certainly late Precambrian; on the Geologic Map it is marked as Precambrian Z.

PRECAMBRIAN Z SUPRACRUSTAL ROCKS OF WESTERN BASIN AND RANGE PROVINCE

Besides the Precambrian supracrustal rocks so far considered, another great sedimentary body in south- 
ern Nevada and eastern California extends conformably through Precambrian $\mathrm{Z}$ and the Lower Cambrian. It is exposed in many of the ranges from the Spring Mountains near Las Vegas westward beyond Death Valley, where it is $13,000 \mathrm{ft}(4,000 \mathrm{~m})$ thick between the Pahrump Group and crystalline basement below, and the Middle Cambrian above (Wright and Troxel, 1966). Farther northwest it is exposed in the Inyo and White Mountains of California and adjacent Esmerelda County, Nevada, where it is as much as $21,000 \mathrm{ft}$ $(6,400 \mathrm{~m})$ thick without visible base (Nelson, 1962); this includes Walcott's type Waucoban Series (=Lower Cambrian Series). Approximately the upper third of the sequence contains diagnostic Lower Cambrian fossils; traces of fossils occur in beds lower down, but most of them are barren; the proper level of the PrecambrianCambrian boundary in the sequence is problematical (see below).

A comprehensive review has been made by Stewart (1970) of the stratigraphy of the units in this rock body, with results summarized in table 6 .

As indicated by the table, the recognizable formations in the sequence fall naturally into three belts from east to west (or southeast to northwest), in each of which is a set of widely recognizable rock units, that cannot be traced directly into the units of the other belts because of disconnected exposures. Hence there are some uncertainties as to correlation, although fairly satisfactory results can be obtained by matching successive measured stratigraphic sections.

On the Geologic Map of the United States the lower part of the sequence is indicated as $\mathrm{Z}$ and the upper part is included in unit $€$. Compilation of the map was completed before the results of Stewart's survey became available, and was based on different assumptions. The Noonday Dolomite and Stirling Quartzite of the central belt were thought to be correlative with the lithically similar Reed Dolomite and Campito Formation (= Sandstone) of the much thicker western sequence, whereas Stewart places both of the last two at a higher stratigraphic level. Moreover, it was assumed that the bases of the Stirling and Campito were a "natural" base of the Cambrian; whereas Stewart places the base of the Cambrian higher up, showing not only that the boundaries in the two areas are not correlative, but that no "natural" boundary exists in a conformable sequence of this kind. These discrepancies, while seemingly fundamental, actually do not greatly distort the representation on the small scale of the Geologic Map.

The Precambrian Z-Lower Cambrian supracrustal body of the western Basin and Range province is a great sedimentary wedge that was built along the western edge of the North American continent in much the same manner as the Precambrian Y supracrustal Belt deposits were built farther north in the Cordillera several

\begin{tabular}{|c|c|c|}
\hline Western belt & Central belt & Eastern belt \\
\hline Middle Cambrian & Middle Cambrian & Middle Cambrian \\
\hline Mule Spring Limestone & \multirow[t]{2}{*}{ Carrara Formation } & Bright Angel Shale \\
\hline Saline Valley Formation & & Tapeats Sandstone \\
\hline Harkless Formation & Zabriskie Quartzite & \multirow[t]{3}{*}{ Unconformity } \\
\hline Poleta Formation & \multirow[t]{2}{*}{ Wood Canyon } & \\
\hline Campito & & \\
\hline Formation & \multirow[t]{2}{*}{ Formation } & \multirow[t]{6}{*}{ Hiatus } \\
\hline Deep Spring Formation & & \\
\hline Reed Dolomite & \multirow[t]{2}{*}{ Stirling Quartzite } & \\
\hline \multirow[t]{2}{*}{ Wyman Formation } & & \\
\hline & Johnnie Formation & \\
\hline \multirow{2}{*}{ Base not exposed } & Noonday Dolomite & \\
\hline & $\begin{array}{c}\text { Unconformity } \\
\text { Pahrump Group and } \\
\text { crystalline basement }\end{array}$ & $\begin{array}{l}\text { Crystalline } \\
\text { basement }\end{array}$ \\
\hline
\end{tabular}

hundred million years earlier. Like the Belt deposits, it was derived from sedimentary waste derived from the craton, which accumulated to great thickness in a tectonically quiet regime (Stewart, 1970, p. 64-66). The wedge thickens from a few hundred feet in the Grand Canyon and elsewhere along the edge of the Colorado Plateau to more than $21,000 \mathrm{ft}(6,400 \mathrm{~m})$ in the western belt $175 \mathrm{mi}(280 \mathrm{~km})$ distant. In the central belt are thick units of quartzite and fine conglomerate that persist for long distances north-south along the stratigraphic strike, but which fade in the western belt, in the thickest part of the wedge, into fine-grained sandstone, intertongued with siltstone, shaly siltstone, and carbonate rocks (fig. 28).

The problem of the Precambrian-Cambrian boundary in this deposit is more acute than in any other part of the United States. Fossil control disappears downward in a conformable sequence, in which no "natural" sedimentary separation exists. In most of the country there is no problem, as Precambrian and Phanerozoic rocks are separated by prominent unconformities and large hiatuses. Even on the opposite side of the continent, in the Southern Appalachians, where both Precambrian Z and Lower Cambrian are again represented, there is in most places a rather obvious "natural" boundary at the base of the Chilhowee Group.

In the deposits in the western Basin and Range province, olenellid trilobites, archeocyathids, and other 


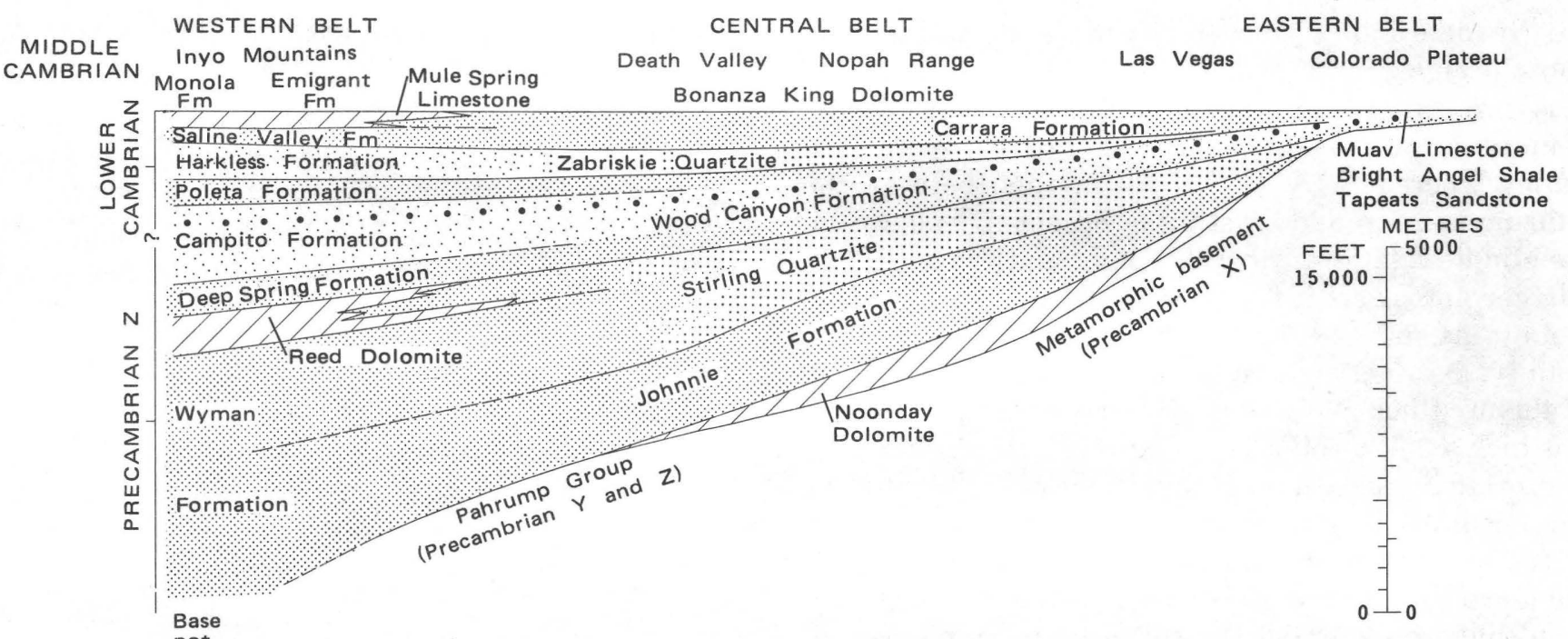

not

exposed
LITHOLOGIES

(Greatly generalized)

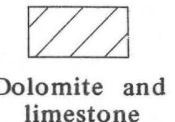

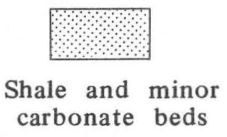

(Gr

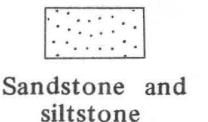

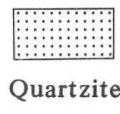

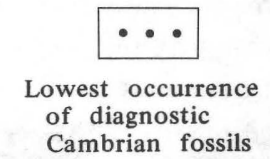

Figure 28.-Stratigraphic diagram showing relations between late Precambrian (Z) and Lower Cambrian units exposed in different areas northwestward across the western Basin and Range province, from the edge of the Colorado Plateau east of Las Vegas, Nevada, to the Inyo Mountains, California. Compiled from Stewart (1970, pl. 2-3). Length of area about $240 \mathrm{mi}(400 \mathrm{~km})$.

diagnostic fossils of the Lower Cambrian are fairly abundant in the upper part, down to the middle of the Wood Canyon Formation in the central belt and the middle of the Campito Formation in the western belt, possibly at nearly the same stratigraphic level. This level is used by Stewart (1970, p. 7) to define the base of the Cambrian, and this may be the best practical solution in a situation of this kind.

Nevertheless, indications of metazoan life extend some distance lower. The lower half of the Wood Canyon in the central belt contains fossil tracks and worm borings. The middle part of the Deep Spring Formation in the western belt contains Rusophycus and Cruziana, which are sitz-marks and crawl-tracks formed by trilobites and other arthropods, that resemble markings in proved Cambrian strata (Cloud and Nelson, 1966, p. 766-768). About $350 \mathrm{ft}(105 \mathrm{~m})$ lower in the formation is a ribbed shell like the problematical genus Pteridinium (=Plagiogomus) which occurs in the Ediacaran, Vendian, and related latest Precambrian units of the Eastern Hemisphere. Near the boundary between the Deep Spring and the Reed Dolomite, $600 \mathrm{ft}(180 \mathrm{~m})$ beneath, is the mollusklike shell Wyattia, resembling globorilids found in Cambrian rocks.

Below the strata in which these remains occur, valid fossil control vanishes; tubular structures of probable algal origin occur in the Noonday Dolomite (Stewart, 1970 , p. 15), and the presence of eucaryotic nannofossils in the Beck Spring Dolomite of the Pahrump Group has already been noted; but both of these can be confidently relegated to the Precambrian.

In summary, part of the sequence under discussion is clearly Precambrian Z and part is clearly Lower Cambrian, but there is no obvious boundary between them. Whatever boundary or boundaries might be selected depend less on the data afforded by the rocks themselves than on the predilections of individual stratigraphers.

\section{DISCUSSION AND SYNTHESIS}

The purpose of the preceding review has been to outline the regional features of the Precambrian rocks of the United States, insofar as they relate to representation of their outcrops on the Geologic Map of the United States. By its very nature the review is thus not a philosophical or speculative treatise on the Precambrian rocks or the history that they imply. Nevertheless, some generalizations emerge that can be summarized here.

It is apparent from the review that the Precambrian of North America (and specifically the Precambrian of Canada and the United States) is not an indecipherable complex of rocks older than the earliest stratified and fossiliferous Phanerozoic rocks. Nor is it an "Archean" complex of crystalline rocks and a "Proterozoic" or "Algonkian" body of less deformed and metamorphosed 
stratified rocks-or, in other terms, an "early" and a "late" Precambrian. Radiometric dating, whatever its defects and pitfalls in detail, has greatly amplified and refined the picture, which will continue to be improved in the future. Using this and other criteria, the Precambrian can now be subdivided and correlated from one region to another, and the results can be represented on regional geologic maps, such as those of Canada (1969) and the United States.

Radiometric dating underscores the great length of Precambrian time-from more than 4,000 m.y. ago to about 600 m.y. ago, or about seven times the length of Phanerozoic time. During this vast interval the earth evolved from its primitive state to one more like that of modern times, with changes in the crust, the hydrosphere, and the atmosphere that influenced the nature of geologic processes (Cloud, 1968, p. 48-51). Nevertheless, the basic laws of matter and energy existed throughout, so that uniformitarian principles apply, at least in modified form.

Thus, as during the Phanerozoic, processes of deformation and plutonism operated in orogenic belts at the same times as cratonic conditions existed elsewhere, and there were no universal Precambrian orogenies, as was formerly believed. Also, if processes of plate tectonics operated during Phanerozoic time, they must have existed during Precambrian time as well, although the obscurity of the record in these ancient rocks precludes the nature of these processes from being more than speculative.

Rates of volcanic and sedimentary accumulation could not have been drastically different from those of Phanerozoic time. It follows that sequences of Precambrian supracrustal rocks, although voluminous in many areas, can only record small samples of the inordinately long span of Precambrian time. The Precambrian sequences in supposedly typical areas, such as the Lake Superior Region, must contain many gaps that are probably represented by volcanism and sedimentation in other areas.

Radiometric dating of Precambrian rocks indicates that there are peaks of abundance of dates during spans of several hundred million years, between which there are spans as long or longer with few or no dates. The times of abundance express the Kenoran, Hudsonian, Elsonian, Grenvillian, and Avalonian events of Canada and the United States. These events have been interpreted as orogenies, but most of them more likely represent orogenic eras or cycles, like the Appalachian and Cordilleran orogenic cycles during Phanerozoic time. As during the Phanerozoic, the effects of the cycles are concentrated in provinces or belts, where the dates are mainly the products of infracrustal metamorphism and plutonism. Comparable dates, if present outside these belts, express merely anorogenic or cratonic processes, such as volcanism, sedimentation, and stray intrusive activity.

Various maps showing radiometric age provinces of parts or all of North America have been compiled (for example, Gastil, 1960, p. 10; Engel, 1963, p. 146; Goldich and others, 1966, p. 5386; King, 1969, p. 38-39). Outside the shield, where exposures are less continuous and more reliance must be placed on subsurface data, these maps are sometimes misleading in detail, because they fail to discriminate between dates of orogenic and anorogenic origin. More expressive, although much more subjective, are sequential maps showing inferred conditions during different parts of Precambrian time (fig. 29).

The maps contribute some evidence, but only partial answers to the question of the evolution of the North American continent. How it was originally created and how it grew has been debated. Some of its continental crust must be very ancient ("Precambrian V" or "Katarchean"); rocks older than 3,200 m.y. have been dated radiometrically in southwestern Minnesota, along the Montana-Wyoming border, and in southwestern Greenland (marked by black triangles in fig. 29A). Other areas of very ancient rocks are suspected elsewhere from geologic evidence but as yet lack radiometric proof. Elsewhere, the main body of Precambrian rocks is younger, Precambrian W ("Archean") or later. One proposed model of the "Katarchean" and "Archean" rocks is that they were "components of emerging proto-cratons and interspersed, subparallel, relatively simatic orogenic belts, presumably involving oceanic spreading centers, arcs, and interarc basins, and subduction zones. By 2,500 m.y. B.P., however, the more 'granitic' proto-cratons converged, telescoping many oceanic, arc-interarc, and borderland environments into subparallel series of synclinoidal 'greenstone' belts" (Engel and others, 1974, p. 843; see also Engel, 1963, p. 146-149; Goodwin, 1974).

By the end of Precambrian W time, cratons had been stabilized by the processes referred to in the Superior province in the center of the continent, and in the Slave and Wyoming provinces to the northwest and southeast (fig. 29A). Precambrian W rocks have also been recognized in the Churchill and Grenville provinces of the Canadian Shield, but they were reworked by subsequent orogenies and not stabilized until later. Following the Kenoran event at the end of Precambrian W time, progressively larger areas of the continent were converted into craton. Stabilization of a province is indicated not only by its internal plutonic and metamorphic history, but also by unconformable overlaps of younger deposits along its edges-for example, the overlap of Precambrian X rocks around the edges of the 
Superior province (fig. 29B). The last part of the Precambrian continent to attain stability was the Grenvillian belt on the southeastern margin, whose metamor- phic and plutonic activity occurred at a time when the remainder of the continent was craton. The contrast is dramatic between the Grenville orogenic belt and the
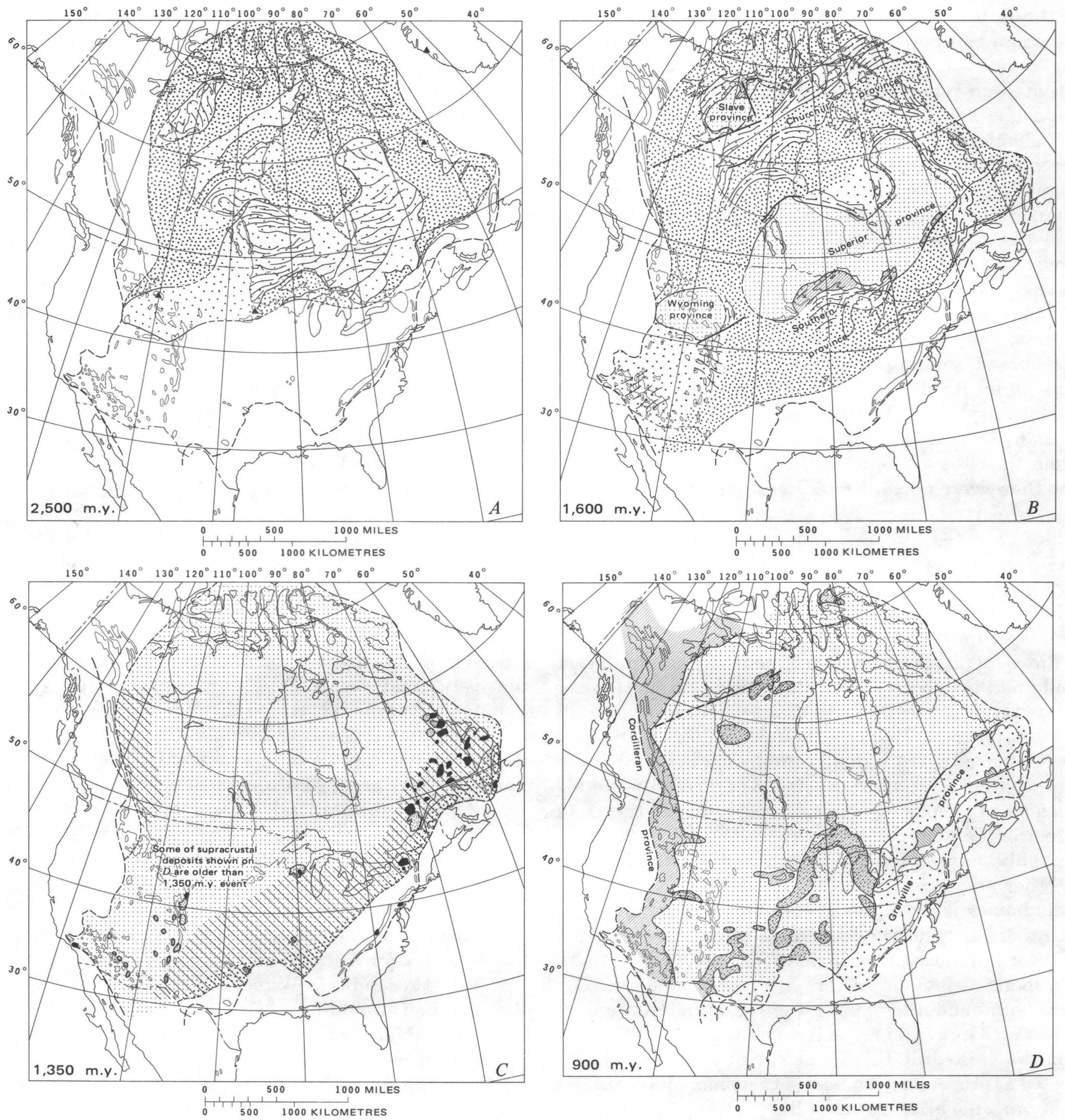

Figure 29.-Maps of the United States and parts of Canada and Mexico, showing evolution of the North American continent during Precambrian time: $A$, At close of Precambrian W (following Kenoran event, about 2,500 m.y. ago). B, At close of Precambrian X (following Hudsonian event, about 1,600 m.y. ago). C, Near middle of Precambrian Y (following Elsonian event, about 1,350 m.y. ago). $D$, Near close of Precambrian Y (following Grenvillian event, about 900 m.y. ago). E, At end of Precambrian (about 600 m.y. ago). No provisions have been made for possible later tectonic distortions. The maps are similar to those of Muehlberger and others (1967, p. 2374-2377), but have been greatly modified from later data, and from predilections of the present author. 
little-disturbed great sedimentary embankment of the Belt Supergroup along the opposite western margin of the continent (fig. 29D).

No Kenoran dates are known in the southern part of the continent, south of Wisconsin and Wyoming (fig. $29 A$ ), where all the dates on the crystalline rocks are

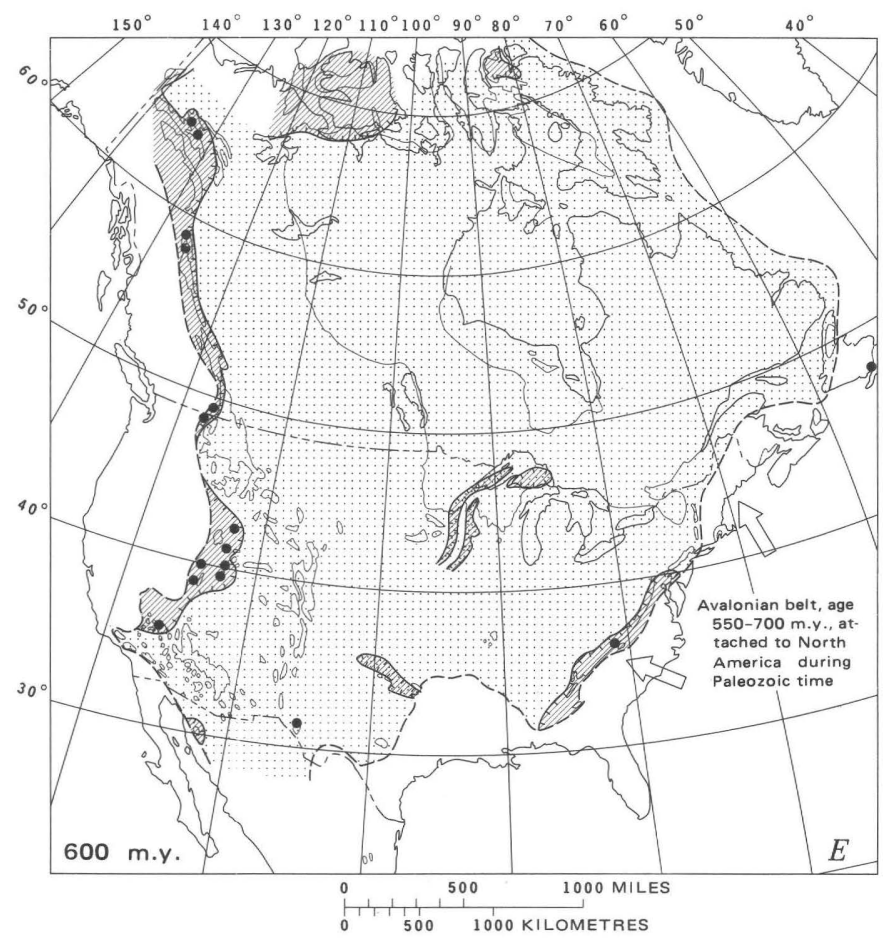

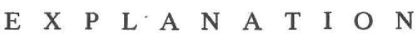

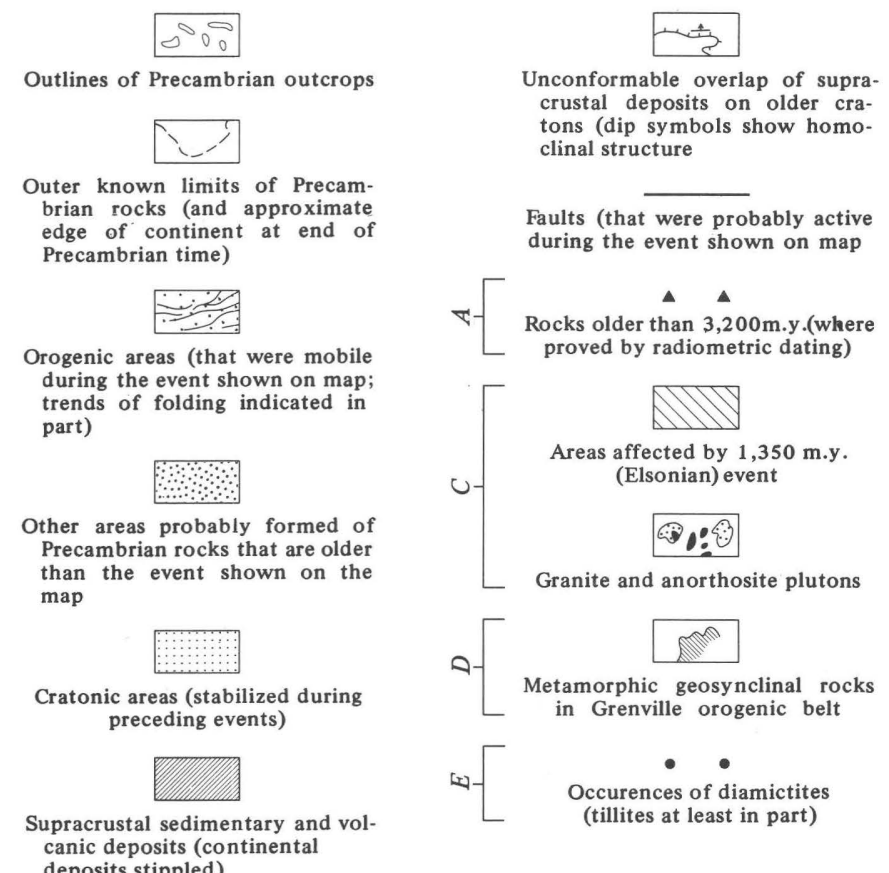

Figure 29.-Continued. younger (fig. 29B). There is a strong possibility that no rocks of Precambrian W ("Archean") ever existed in much of the southern area, suggesting that this part was added to the continent after the Kenoran event.

Similarly, there is a notable absence, in surface or subsurface, of any Precambrian rocks in a large area in the western United States, west of the line shown in figure 30 , and here there is much evidence that the crust was oceanic during Precambrian time, and was not made into continent until Paleozoic time or later. Even the westward projection of known Precambrian rocks nearly to the Pacific Coast in southern California probably reached its present position by shifts of crustal blocks late in Phanerozoic time.

In the maps of figure 29 this line is shown as the approximate western edge of the North American continent at the end of Precambrian time. Similar lines are shown on the maps along the southern and southeastern sides of the continent. The boundary on the south indicates the margin of the Paleozoic Ouachita orogenic belt, where no Precambrian basement has been proved; possibly an original continental crust in this area has been removed by drift during Phanerozoic time to a position south of the Gulf of Mexico. The boundary on the southeast indicates the outer known limit of rocks of the Grenvillian belt; it is true that Precambrian rocks of younger ages in the Avalonian belt lie beyond this through much of the length of the Appalachian chain, but these were probably added to the continent by plate collision during the Phanerozoic.

Available evidence indicates that after the Kenoran event the North American continent was a cohesive body, gradually enlarging by accretion-whatever its movements or its relations in space may have been to other continental plates. The only clear indication of an addition to the continent by plate collision is that of the Avalonian belt just referred to.

Final Precambrian time (Precambrian Z or "Hadrynian") has been poorly appreciated because of its scanty representation in the Central Interior-at most perhaps by continental deposits like the Bayfield Group of the Lake Superior Region, and by part of the volcanic and clastic rocks in the Wichita trough farther south (fig. 29E). Major depositional events had now shifted to the eastern and western margins of the continent, in the Appalachian and Cordilleran belts, where marine sediments and minor volcanics accumulated, forming sequences quite as impressive as those of earlier Precambrian times, that lead upward with only slight interruption into the Paleozoic geosynclinal deposits. Precambrian $\mathrm{Z}$ deposits on the east are less mature than those of the succeeding Paleozoic, indicating accumulation under conditions of some tectonic disturbance. Those on the west, especially those now preserved in the 

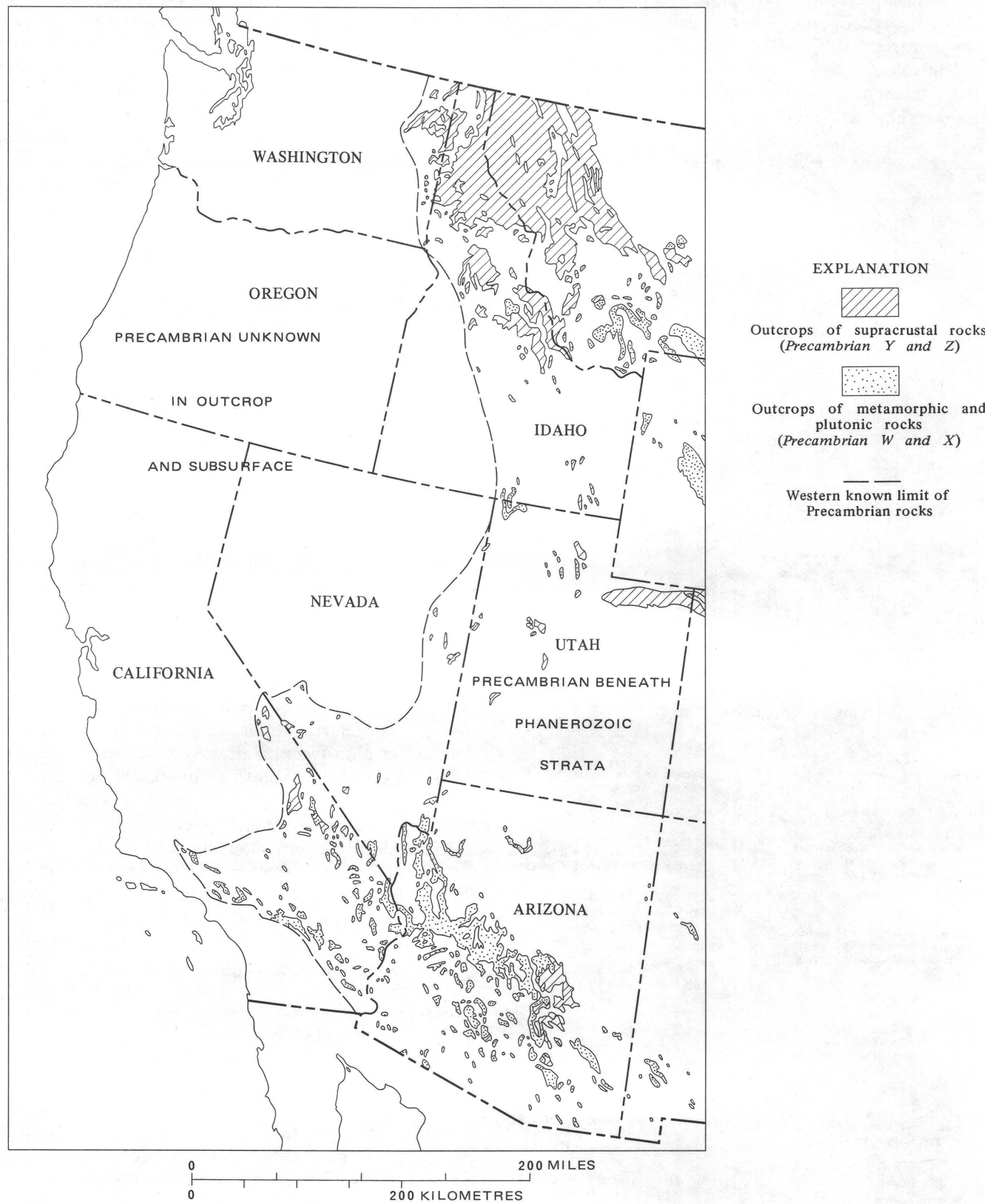

FIgURE 30.-Map of western United States, showing western known extent of Precambrian rocks. 
western Basin and Range province, formed under conditions of crustal stability quite the equal of those accompanying the earlier Belt sedimentation in the same region.

Diamictites occur near the base of the Precambrian Z deposits throughout much of their extent in the Cordilleran belt on the west, and at two localities in the Appalachian belt on the east. It is tempting to correlate these with the extensive glacial deposits of late Precambrian time that have been proved in many of the other continents, and to consider all of them as a possible time marker. Absolute proof of glacial origin is not available for all the diamictites in the United States and Canada, and the known pole positions of the time do not accord well with the supposed refrigeration. Nevertheless, the regional extent of the deposits and the variety of their component clasts point to controlling conditions quite different from mere mudslides or other locally triggered deposits.

The much debated question of the boundary between the Precambrian and the Cambrian need not concern us greatly here. Throughout the Central Interior and the eastern part of the Cordilleran belt rocks younger than earliest Cambrian lie unconformably on Precambrian rocks, which are partly supracrustal, but in more places a crystalline infracrustal basement. The question of the boundary only arises in the interiors of the Appalachian and Cordilleran belts, where the latest Precambrian (Z) and the Cambrian are present in the same sequences. Here, the rocks were orogenically deformed during Phanerozoic time and the outcrop bands of the debated rocks are very narrow, so that for purposes of the Geologic Map of the United States the question can be disregarded. A significant point is that Precambrian and Cambrian are not necessarily unconformable (as they are in the craton), and that no "Lipalian" or lost interval separates them.

\section{ACKNOWLEDGMENTS}

This review could not have been made without the information, aid, and counsel of those of my colleagues on the staff of the Geological Survey who are also interested in the Precambrian rocks of the United States. Among the many who have so contributed are Charles A. Anderson, Helen M. Beikman, Max D. Crittenden, Jr., Harold L. James, Zell E. Peterman, Gershon D. Robinson, and John H. Stewart, some of whom have reviewed parts or all of the manuscript during its various stages of evolution. Needless to say, however, the report is neither a collective statement of their opinions, nor a definitive official statement of the U.S. Geological Survey; I assume sole responsibility for the views expressed.
I am also deeply grateful for the advice and inspiration I have received, during or before the preparation of the report, from Preston E. Cloud, Jr., of the University of California, Santa Barbara, and Clifford H. Stockwell of the Geological Survey of Canada, whose larger insights into Precambrian problems have done much to sharpen my own perceptions.

\section{REFERENCES CITED}

Aalto, K. R., 1971, Glacial marine sedimentation and stratigraphy of the Toby Conglomerate (Upper Proterozoic), southeastern British Columbia, northwestern Idaho, and northeastern Washington: Canadian Jour. Earth Sci., v. 8, no. 7, p. 753-787.

Adams, F D., Bell, Robert, Lane, A. C., Leith, C. K., Miller, W. G., and Van lise, R. R., 1905, Report of the Special Committee on the Lake Superior Region: Jour. Geology, v. 13, no. 2, p. 89-104.

Aldrich, L. T., Davis, G. L., and James, H. L., 1965, Ages of minerals from metamorphic and igneous rocks near Iron Mountain, Michigan: Jour. Petrology, v. 6, pt. 3, p. 445-472.

Anderson, C. A., 1968, Metamorphosed Precambrian silicic volcanic rocks in central Arizona, in Coats, R. R., Hay, R. L., and Anderson, C. A., eds., Studies in volcanology: Geol. Soc. America Mem. 116 , p. 9-44.

Anderson, C. A., Blacet, P. M., Silver, L. T., and Stern, T. W., 1971, Revision of Precambrian stratigraphy in the Prescott-Jerome area, Yavapai County, Arizona: U.S. Geol. Survey Bull. 1324-C, p. C1-C16.

Armstrong, R. L., 1975, Precambrian (1,500 m.y. old) rocks of central Idaho; the Salmon River arch and its role in Cordilleran sedimentation and tectonics: Am. Jour. Sci., v. 275-A, p. 437-467.

Armstrong, R. L., and Hills, F. A., 1967, Rb/Sr and K/Ar geochronologic studies of mantled gneiss domes, Albion Range, southern Idaho, U.S.A.: Earth and Planetary Sci. Letters, v. 3, no. 2, p. 114-124.

Barker, Fred, 1969, Precambrian geology of the Needle Mountains, southwestern Colorado: U.S. Geol. Survey Prof. Paper 644-A, $35 \mathrm{p}$.

Bayley, R. W., 1968, Ore deposits of the Atlantic City district, Fremont County, Wyoming, in Ridge, J. D., ed., Ore deposits of the United States, 1933-67 (Graton-Sales Volume): Am. Inst. Mining, Metall., and Petroleum Engineers, v. 1, p. 568-604.

1970, Structure and mineralization of Precambrian rocks in the Galena-Roubaix district, Black Hills, South Dakota: U.S. Geol. Survey Bull. 1312-E, p. E1-E15.

-1972a, A preliminary report on the geology and gold deposits of the Rochford district, Black Hills, South Dakota: U.S. Geol. Survey Bull. 1332-A, p. A3-A24.

$-1972 b$, Preliminary geologic map of the Nemo district, Black Hills, South Dakota: U.S. Geol. Survey Misc. Geol. Inves. Map I-712, scale 1:24,000.

-1972c, Geologic field compilation map of the northern Black Hills, South Dakota: U.S. Geol. Survey open-file report, scale $1: 48,000$.

Bayley, R. W., and James, H. L., 1973, Precambrian iron formations in the United States, in James, H. L., and Sims, P. K., eds., Precambrian iron formations of the world: Econ. Geology, v. 68, no. 7, p. 934-959.

Bayley, R. W., and Muehlberger, W. R., 1968, Basement rock map of the United States, exclusive of Alaska and Hawaii: U.S. Geol. Survey, scale 1:2,500,000.

Becker, G. F., 1908, Relations of radioactivity to cosmology and geology: Geol. Soc. America Bull., v. 19, no. 2, p. 113-146. 
Bentley, R. D., and Neathery, T. L., 1970, Geology of the Brevard fault zone and related rocks of the inner Piedmont of Alabama: Alabama Geol. Society 8th Ann. Field Trip Guidebook (Dec. 4-5, 1970), $119 \mathrm{p}$.

Bickford, M. E., 1972, Chronology of igneous events in the Precambrian of the St. Francois Mountains, southeast Missouri; U/Pb ages of zircons and $\mathrm{Rb} / \mathrm{Sr}$ ages of whole rocks and mineral separates [abs.]: Geol. Soc. America Abs. with Programs, v. 4, no. 7 (Ann. Mtg., Minneapolis), p. 451-452.

Bickford, M. E., Wetherill, G. W., Barker, Fred, and Lee-Hu, ChinNan, 1967, Precambrian Rb/Sr chronology in the Needle Mountains, southwestern Colorado: Jour. Geophys. Research, v. 74, no. 6; p. $1660-1676$.

Blackwelder, Eliot, 1926, Precambrian geology of the Medicine Bow Mountains: Geol. Soc. America Bull., v. 37, no. 4, p. 615-658.

1932, An ancient glacial formation in Utah: Jour. Geology, v. 40, no. 4, p. 289-304.

Bloomer, R. O., and Werner, H. J., 1955, Geology of the Blue Ridge region in central Virginia: Geol. Soc. America Bull., v. 66, no. 5, p. 579-606.

Boone, G. M., Boudette, E. L., and Moench, R. H., 1970, Bedrock geology of the Rangeley Lakes-Dead River basin, western Maine, in Boone, G. M., ed., Guidebook for field trips in the Rangeley Lakes-Dead River basin region, western Maine: New England Intercollegiate Geol. Conf., 63rd Ann. Mtg., p. 1-24.

Buddington, A. F., 1939, Adirondack igneous rocks and their metamorphism: Geol. Soc. America Mem. 7, 354 p.

Burchfiel, B. C., and Livingston, J. L., 1967, Brevard zone compared to Alpine root zones: Am. Jour. Sci., v. 265, no. 4, p. 241-256.

Butler, J. R., 1966, Geologic evolution of the Beartooth Mountains, Montana and Wyoming, pt. 6, Cathedral Peak area, Montana: Geol. Soc. America Bull., v. 77, no. 1, p. 45-64.

Cannon, W. F., and Gair, J. E., 1970, A revision of stratigraphic nomenclature for the middle Precambrian rocks in northern Michigan: Geol. Soc. America Bull., v. 81, no. 9, p. 2843-2846.

Carroll, Dorothy, Neuman, R. B., and Jaffe, H. W., 1957, Heavy minerals in arenaceous beds in part of the Ocoee Series, Great Smoky Mountains, Tennessee: Am. Jour. Sci., v. 255, no. 3, p. 175-193.

Carter, Bruce, and Silver, L. T., 1971, Post-emplacement structural history of the San Gabriel anorthosite complex [abs.]: Geol. Soc. America Abstracts with Programs, v. 3, no. 2 (Cordilleran Section 64th Ann. Mtg.), p. 193-194.

Catanzaro, E. J., 1966, Correlation of some Precambrian rocks and metamorphic events in parts of Wyoming and Montana: Mountain Geologist, v. 4, no. 1, p. 9-21.

Clark, S. H. B., 1973, Interpretation of a high-grade Precambrian terrane in northern Idaho: Geol. Soc. America Bull., v. 84, no. 6, p. 1999-2004.

Cloud, P. E. Jr., 1968, Pre-metazoan evolution and the origins of the Metazoa, in Drake, E. T., ed., Evolution and environment: Yale Univ. Press, New Haven, p. 1-72.

Cloud, P. E., Jr., Licari, G. R., Wright, L. A., and Troxel, B. W., 1969 Proterozoic eucaryotes from eastern California: Natl. Acad. Sci. Proc., v. 62, no. 3, p. 623-630.

Cloud, P. E., Jr., and Nelson, C. A., 1966, Paleozoic-Cryptozoic and related transitions; new evidence: Science, v. 154 , no. 3750 , p. 765-769.

Cloud, P. E., Jr., and Semikhatov, M. A., 1969, Proterozoic stromatolite zonation: Am. Jour. Sci., v. 267, no. 9, p. 1017-1061.

Condie, K. C., 1967, Petrology of the late Precambrian tillite(?) association in northern Utah: Geol. Soc. America Bull., v. 78, no. 11, p. $1317-1344$.

Conley, J. F., and Henika, W. S., 1973, Geology of the Snow Creek,
Martinsville East, Price, and Spray quadrangles, Virginia: Virginia Div. Mineral Resources Rept. Inv. 33, 71 p.

Cooper, J. R., and Silver, L. T., 1964, Geology and ore deposits of the Dragoon quadrangle, Cochise County, Arizona: U.S. Geol. Survey Prof. Paper 416, 196 p.

Crittenden, M. D., Jr., McKee, E. H., and Peterman, Z. E., 1971, 1.5-billion-year-old rocks in the Willard thrust sheet, Utah [abs.]: Geol. Soc. America Abstracts with Programs, v. 3, no. 2 (Cordilleran Section 67th Ann. Mtg.), p. 105-106.

Crittenden, M. D., Jr., Schaeffer, F. E., Trimble, D. E., and Woodward, L. A., 1971, Nomenclature and correlation of some upper Precambrian and basal Cambrian sequences in western Utah and southeastern Idaho: Geol. Soc. America Bull., v. 82, no. 3, p. 581-602.

Crittenden, M. D., Jr., Sharp, B. J., and Calkins, F. C., 1952, Parleys Canyon to Tranverse Ranges, in Geology of the central Wasatch Mountains, Utah: Utah Geol. Society Guidebook to the Geology of Utah, no. 8, p. 1-37.

Crittenden, M. D., Jr., Stewart, J. H., and Wallace, C. A., 1972, Regional correlation of upper Precambrian strata in western North America: Internat. Geol. Cong. 24th (Canada), sec. 1, p. 334-361.

Crittenden, M. D., Jr., and Wallace, C. A., 1973, Probable equivalents of the Belt Supergroup in Utah, in Belt symposium, 1973, v. 1: Idaho Bur. Mines and Geol., p. 116-138.

Crowell, J. C., and Walker, J. W. R., 1962, Anorthosite and related rocks along the San Andreas fault, southern California: California Univ. Pubs. Geol. Sci., v. 40, p. 219-288.

Daly, R. A., 1912, Geology of the North American Cordillera at the Forty-ninth Parallel: Canada Geol. Survey Mem. 38, pt. 1, 546 p.

Dalziel, I. W. D., and Dott, R. H., Jr., 1970, Geology of the Baraboo district, Wisconsin: Wisconsin Geol. and Nat. History Survey Inf. Circ. 14, 164 p.

Darton, N. H., 1925, A resume of Arizona geology: Arizona Bur. Mines Bull. 119, 208 p.

Darton, N. H., and Paige, Sidney, 1925, Description of the central Black Hills, South Dakota: U.S. Geol. Survey Geol. Atlas, Folio 219, $34 \mathrm{p}$.

Deiss, Charles, 1935, Cambrian-Algonkian unconformity in western Montana Geol. Soc. America Bull., v. 46, no. 1, p. 95-124.

Dibblee, T. W., Jr., 1968, Displacements on the San Andreas fault system in the San Gabriel, San Bernardino, and San Jacinto Mountains, southern California, in Dickinson, W. R., and Grantz, Arthur, eds., Proceedings of conference on geologic problems of San Andreas fault system: Stanford Univ. Pubs. Geol. Sci., v. 11, p. 260-277.

Douglas, R. J. W., Gabrielse, H., Wheeler, J. O., Stott, D. F., and Belyea, H. R., 1970, Geology of western Canada, in Douglas, R. J. W., ed., Geology and economic minerals of Canada: Canada Geol. Survey Econ. Geol. Rept. 1, 5th ed., p. 366-488.

Dowse, A. M., 1950, New evidence on the Cambrian contact at Hoppin Hill, North Attleboro, Massachusetts: Am. Jour. Sci., v. 268, no. 2, p. $95-99$.

Drake, A. A., Jr., 1970, Structural geology of the Reading Prong, in Fisher, G. W., Pettijohn, F. J., Reed, J. C., Jr., and Weaver, K. N., eds., Studies of Appalachian geology; Central and Southern: Interscience Publishers, New York, p. 271-291.

Dutton, C. E., and Bradley, R. E., 1970, Lithologic, geophysical, and mineral commodity maps of Precambrian rocks in Wisconsin: U.S. Geol. Survey Misc. Geol. Inv. Map I-631, scale 1:500,000.

Eardley, A. J., and Hatch, R. A., 1940a, Precambrian crystalline rocks of north-central Utah: Jour. Geology, v. 48, no. 1, p. 58-72. 1940 b, Proterozoic(?) rocks in Utah: Geol. Soc. America Bull., v. 51 , no. 6, p. $795-844$. 
Eckelmann, F. D., and Poldervaart, Arie, 1957, Geologic evolution of the Beartooth Mountains, Montana and Wyoming, pt. 1, Archean history of the Quad Creek area: Geol. Soc. America Bull., v. 68, no. 10, p. 1225-1262.

Emslie, R. F., 1970, Grenville province, in Douglas, R. J. W., ed., Geology and economic minerals of Canada: Canada Geol. Survey Econ. Geol. Rept. 1, 5th ed., p. 121-145.

Engel, A. E. J., 1963, Geologic evolution of North America: Science, v. 140 , no. 2563 , p. $143-152$.

Engel, A. E. J., and Engel, C. G., 1954, Grenville Series in the northwest Adirondack Mountains, New York; part 1, General features of the Grenville Series: Geol. Soc. America Bull. v. 64, no. 9, p. 1013-1047.

Engel, A. E. J., Itson, S. P., Engel, C. G., Stickney, D. M. and Cray, E. J., Jr., 1974, Crustal evolution and global tectonics; a petrogenic view: Geol. Soc. America Bull., v. 85, p. 843-848.

Fairbairn, H. W., Moorbath, S., Ramo, A. O., Pinson, W. H., Jr., and Hurley, P. M., 1967, Rb/Sr age of granitic rocks of southeastern Massachusetts and the age of the Lower Cambrian at Hoppin Hill: Earth and Planetary Sci. Letters, v. 2, p. 321-328.

Faul, Henry, Stern, T. W., Thomas, H. H., and Elmore, P. L. D., 1963, Ages of intrusion and metamorphism in the Northern Appalachians: Am. Jour. Sci., v. 261, no. 1, p. 1-19.

Fenton, M. D., and Faure, G., 1969, Another age determination of the Stillwater Complex, Montana, by the total-rock Rb/Sr method [abs.], in Abstracts for 1968: Geol. Soc. America Spec. Paper 121, p. 656-657.

Flawn, P. T., 1956, Basement rocks of Texas and southeast New Mexico: Texas Univ. Bur. Econ. Geol. Pub. 5605, 261 p.

Flawn, P. T., and Muehlberger, W. R., 1970, The Precambrian of the United States of America; south-central United States, in Rankama, Kalervo, ed., The Precambrian, v. 4: Interscience Publishers, New York, p. 73-143.

Ford, T. D., and Breed, W. J., 1972, The problematical Precambrian fossil Chuaria: Internat. Geol. Cong. 24th (Canada), sec. 1, p. $11-18$.

1973, Late Precambrian Chuar Group, Grand Canyon, Arizona: Geol. Soc. America Bull., v. 84, no. 4, p. 1243-1260.

Fullagar, P. D., and Odom, A. L., 1973, Geochronology of Precambrian gneisses in the Blue Ridge province of northwestern North Carolina and adjacent parts of Virginia and Tennessee: Geol. Soc. America Bull., v. 84, no. 9, p. 2065-3080.

Gabrielse, Hugh, 1972, Younger Precambrian of the Canadian Cordillera: Am. Jour. Sci., v. 272, no. 6, p. 521-536.

Gastil, Gordon, 1958, Older Precambrian rocks of the Diamond Butte quadrangle, Gila County, Arizona: Geol. Soc. America Bull., v. 69, no. 12, p. 1495-1514.

1960 , The distribution of mineral dates in time and space: Am. Jour. Sci., v. 258, no. 1, p. 1-35.

Giletti, B. J., 1966, Isotopic ages from southwestern Montana: Jour. Geophys. Research, v. 71, no. 16, p. 4029-4036.

Giletti, B. J., and Damon, P. E., 1961, Rubidium-strontium ages of some basement rocks from Arizona and northwestern New Mexico: Geol. Soc. America Bull., v. 72, p. 639-644.

Gilluly, James, 1966, Orogeny and geochronology: Am. Jour. Sci., v. 264, no. 2, p. 97-111.

Glaessner, M. F., 1961, Pre-Cambrian animals: Scientific American, v. 204 , no. 3 , p. $72-78$.

1968, Biological events and the Precambrian time scale: Can. Jour. Earth Sci., v. 5, no. 3, p. 585-590.

-1971, Geographic distribution and time range of the Ediacara Precambrian fauna: Geol. Soc. America Bull., v. 82, no. 2, p. 509-514.

Glover, Lynn, III, and Sinha, A. K., 1973, The Virgilina deformation, a late Precambrian to early Cambrian(?) orogenic event in the central Piedmont of Virginia and North Carolina: Am. Jour. Sci., v. 273-A (Cooper volume), p. 234-251.

Goldich, S. S., 1968, Geochronology in the Lake Superior Region: Canadian Jour. Earth Sci., v. 5, no. 3, p. 715-724.

Goldich, S. S., Lidiak, E. G., Hedge, C. E., and Walthall, F. G., 1966, Geochronology of the Midcontinent Region, United States; pt. 2, Northern area: Jour. Geophys. Research, v. 71, no. 22, p. 53895406.

Goldich, S. S., Muehlberger, W. R., Lidiak, E. G., and Hedge, C. E., 1966, Geochronology of the Midcontinent Region, United States; pt. 1, Scope, methods, and principles: Jour. Geophys. Research, v. 71, no. 22, p. 5375-5388.

Goldich, S. S., Nier, A. O., Baadsgaard, Haltdam, Hoffman, J. H., and Krueger, H. W., 1961, The Precambrian geology and geochronology of Minnesota: Minnesota Geol. Survey Bull. 41, 193 p.

Goodwin, A. M., 1974, Precambrian belts, plumes, and shield development: Am. Jour. Sci., v. 274, p. 987-1028.

Grout, F. F., Gruner, J. W., Schwartz, G. M., and Thiel, G. A., 1951, Precambrian stratigraphy of Minnesota: Geol. Soc. America Bull., v. 62, no. 9, p. 1017-1078.

Gussow, W. C., 1973, Chuaria cf. C. circularis Walcott from the Precambrian Hector Formation, Banff National Park, Alberta: Jour. Peleontology, v. 47, p. 1108-1112.

Hadley, J. B., 1969a, Geologic map of the Cameron quadrangle, Madison County, Montana: U.S. Geol. Survey Geol. Quad. Map GQ813 , scale 1:62,500.

-1969b, Geologic map of the Varney quadrangle, Madison County, Montana: U.S. Geol. Survey Geol. Quad. Map GQ-814. Scale 1:62,500.

1970, The Ocoee Series and its possible correlatives, in Fisher, G. W., Pettijohn, F. J., Reed, J. C., Jr., and Weaver, K. N., eds. Studies of Appalachian geology; Central and Southern: Interscience Publishers, New York, p. 227-245.

Hadley, J. B., and Nelson, A. E., 1971, Geologic map of the Knoxville quadrangle, North Carolina, Tennessee, and South Carolina: U.S. Geol. Survey Misc. Geol. Inv. Map I-654, scale 1:250,000.

Hall, L. M., 1968, Times and origin of deformation of bedrock in the Manhattan prong, in Zen, E-an, White, W. S., Hadley, J. B., and Thompson, J. B., Jr., eds., Studies of Appalachian geology; Northern and Maritime: Interscience Publishers, New York, p. 117127.

Halls, H. C., 1966, A review of the Keweenawan geology of the Lake Superior Region, in Steinhart, J. S., and Smith, T. J., eds., The earth beneath the continents: Am. Geophys. Union Geophys. Mon. 10, p. 3-27.

Ham, W. E., Denison, R. E., and Merritt, C. A., 1964, Basement rocks and structural evolution of southern Oklahoma: Oklahoma Geol. Survey Bull. 95, 302 p.

Hamblin, W. K., 1961, Paleogeographic evolution of the Lake Superior Region from late Keweenawan to late Cambrian time: Geol. Soc. America Bull., v. 72, no. 1, p. 1-18.

Hansen, W. R., 1965, Geology of the Flaming Gorge area, UtahColorado-Wyoming: U.S. Geol. Survey Prof. Paper 490, 196 p.

Harbour, R. L., 1960, Precambrian rocks at North Franklin Mountain, Texas: Am. Assoc. Petroleum Geologists Bull., v. 44, no. 11, p. 1785-1792.

-1972, Geology of the northern Franklin Mountains, Texas and New Mexico: U.S. Geol. Survey Bull. 1289, 129 p.

Harrison, J. E., 1972, Precambrian Belt basin of northwestern United States; its geometry, sedimentation, and copper occurrences: Geol. Soc. American Bull., v. 83, no. 5, p. 1215-1240.

Harrison, J. E., Griggs, A. B., and Wells, J. D., 1974, Tectonic features of the Precambrian Belt basin and their influence on post-Belt 
structures: U.S. Geol. Survey Prof. Paper 866, 15 p.

Hatcher, R. D., Jr., 1971, Geology of Rabun and Habersham Counties, Georgia: Georgia Geol. Survey Bull. 83, 48 p.

- 1973, Basement versus cover rocks in the Blue Ridge of northeast Georgia, northwestern South Carolina, and adjacent North Carolina: Am. Jour. Sci., v. 273, no. 8, p. 671-685.

Hedge, C. E., 1970, Whole-rock Rb/Sr age of Pikes Peak batholith, Colorado, in Geological Survey research 1970: U.S. Geol. Survey Prof. Paper 700-B, p. B86-B89.

Hedge, C. E., Peterman, Z. E., and Braddock, W. A., 1967, Age of the major Precambrian regional metamorphism in the northern Front Range, Colorado: Geol. Soc. America Bull., v. 78, no. 4, p. 551-558.

Hills, F. A., and Armstrong, R. L. 1971, Rb/Sr and K/Ar geochronology of the Laramie Range, southern Wyoming [abs.]: Geol. Soc. America Abstracts with Programs, v. 3, no. 7, 1971 Ann. Mtg., p. 599-600.

Hills, F. A., Gast, P. W., Houston, R. S., and Swainbank, I. G., 1968, Precambrian geochronology of the Medicine Bow Mountains, southeastern Wyoming: Geol. Soc. American Bull., v. 79, no. 12, p. $1757-1784$.

Houston, R. S., and others, 1968, A regional study of rocks of Precambrian age in that part of the Medicine Bow Mountains lying in southeastern Wyoming, with a chapter on the relationship between Precambrian and Laramide structure: Wyoming Geol. Survey Mem. 1, $167 \mathrm{p}$.

Hughes, C. J., 1970, The late Precambrian Avalonian orogeny in Avalon, southeast Newfoundland: Am. Jour. Sci., v. 269, no. 2, p. 183-190.

Hughes, C. J., and Brückner, W. D., 1971, Late Precambrian rocks of eastern Avalon Peninsula, Newfoundland; a volcanic island complex: Canadian Jour. Earth Sci., v. 8, p. 899-915.

Hurst, V. J., 1973, Geology of the southern Blue Ridge belt: Am. Jour. Sci., v. 273 , no. 8 , p. 643-670.

James, H. L., 1955, Zones of regional metamorphism in the Precambrian of northern Michigan: Geol. Soc. America Bull., v. 66, no. 12 , p. $1455-1488$.

1958, Stratigraphy of pre-Keweenawan rocks in parts of northern Michigan: U.S. Geol. Survey Prof. Paper 314-C, p. 27-44.

-1960, Problems of stratigraphy and correlation of Precambrian with particular reference to the Lake Superior Region: Am. Jour. Sci., v. 258-A (Bradley volume), p. 104-114.

-1972a, Stratigraphic Commission note 40; Subdivisions of Precambrian, an interim scheme to be used by the U.S. Geological Survey: Am. Assoc. Petroleum Geologists Bull., v. 56, no. 6, p. 1128-1133.

-1972b, Subdivision of Precambrian; reply: Am. Assoc. Petroleum Geologists Bull., v. 56, no. 10, p. 2084-2086.

Johnson, B. K., 1957, Geology of a part of the Manly Peak quadrangle, southern Panamint Range, California: California Univ. Pubs. Geol. Sci., v. 30, no. 5, p. 35i3-424.

Jonas, A. I., and Stose, G. W., 1؟139, Age relation of the Precambrian rocks in the Catoctin Mourtain-Blue Ridge and Mount Rogers anticlinoria in Virginia: Ann. Jour. Sci., v. 237, no. 8, p. 575-593.

Jones, W. R., Peoples, J. W., and Howland, A. L., 1960, Igneous and tectonic structures of the Stillwater Complex, Montana: U.S. Geol. Survey Bull. 1071-H, p. H281-H340.

King, E. R., and Zietz, Isadore, 1971, Aeromagnetic study of the Midcontinent gravity high of central United States: Geol. Soc. America Bull., v. 82, no. 8, p. 2187-2208.

King, P. B., 1969, The tectonics of North America; a discussion to accompany the Tectonic Map of North America, scale 1:5,000,000: U.S. Geol. Survey Prof. Paper 628, 95 p.

1970, The Precambrian of the United States of America; southeastern United States; in Rankama, Kalervo, ed., The Precambrian, v. 4: Interscience Publishers, New York, p. 1-71.
King, P. B., and Beikman, H. M., 1974, An explanatory test to accompany the geologic map of the United States: U.S. Geol. Survey Prof. Paper 901, 44 p. (1975).

King, P. B., and Flawn, P. T., 1953, Geology and mineral deposits of the Precambrian rocks of the Van Horn area, Texas: Texas Univ. Bur. Econ. Geol. Pub. 5301, 218 p.

King, P. B., Neuman, R. B., and Hadley, J. B., 1968, Geology of the Great Smoky Mountains, Tennessee and North Carolina: U.S. Geol. Survey Prof. Paper 587, 23 p.

Kistler, R. W., Obradovich, J. D., and Jackson, E. D., 1968, Isotopic ages of rocks and minerals from the Stillwater Complex, Montana [abs.], in Abstracts for 1967: Geol. Soc. America Spec. Paper 115, p. 120-121.

Krieger, M. H., 1968, Stratigraphic relations of the Troy Quartzite (younger Precambrian) and the Cambrian formations in southeastern Arizona, in Titley, S. R., ed., Southern Arizona guidebook III: Arizona Geol. Society, Geol. Soc. America Cordilleran Sec., 64th Ann. Mtg, p. 23-32.

Kulp, J. L., and Eckelmann, F. D., 1961, Potassium-argon ages on micas from the Southern Appalachians, in Geochronology of rock systems: New York Acad. Sci. Annals, v. 69, art. 2, p. 408-419.

Lanphere, M. A., 1964, Geochronologic studies in the eastern Mojave Desert, California: Jour. Geology, v. 72, no. 4, p. 381-419.

Lawson, A. C., 1914, A standard scale for the Pre-cambrian rocks of North America: Internat. Geol. Cong., 12th (Canada), Compte Rendu, p. 349-370.

Leith, C. K., 1934, The Precambrian: Geol. Soc. America Proc. for 1933 , p. $151-180$.

Livingston, D. E., and Damon, P. E., 1968, The ages of stratified Precambrian rock sequences in central Arizona and northern Sonora: Canadian Jour. Earth Sci., v. 5, no. 3, pt. 2, p. 763-772.

Long, L. E., and Kulp, J. L., 1962, Isotopic age study of the metamorphic history of the Manhattan and Reading Prongs: Geol. Soc. America Bull., v. 73, no. 8, p. 969-996.

McGowen, J. H., and Groat, C. J., 1971, Van Horn Sandstone, west Texas; an alluvial fan model for mineral exploration: Texas Bur. Econ. Geology Rept. Inv. 72, 57 p.

McKee, E. H., and Noble, D. C., 1974, Radiometric ages of diabase sills and basaltic lava flows in the Unkar Group, Grand Canyon [abs.]: Geol. Soc. America Abstracts with Programs, v. 6, no. 5 (Rocky Mountain Section, 27th Ann. Mtg.), p. 458.

McLaughlin, R. E., and Hathaway, R. E., 1973, Fossils in the Murphy Marble [abs.]: Geol. Soc. America Abs. with Programs, v. 5, no. 5 (Southeastern Sec. 22d Ann. Mtg.), p. 418-419.

McMannis, W. J., 1963, La Hood Formation, a coarse facies of the Belt Series in southwestern Montana: Geol. Soc. America Bull., v. 74, no. 4, p. 407-436.

Mallory, W. W., 1972, Pennsylvanian arkose and the Ancestral Rocky Mountains, in Mallory, W. W., ed., Geologic Atlas of the Rocky Mountain Region, United States of America: Rocky Mountain Assoc. Geol., Denver, Colo., p. 121-132.

Maxson, J. H., 1961, Geologic map of the Bright Angel quadrangle, Grand Canyon National Park, Arizona: Grand Canyon Nat. Hist. Assoc. (Scale 1:24,000.)

Miller, F. K., McKee, E. H., and Yates, R. G., 1973, Age and correlation of the Windermere Group in northeastern Washington: Geol. Soc. America Bull., v. 84, no. 11, p. 2723-2730.

Misch, Peter, and Hazzard, J. C., 1962, Stratigraphy and metamorphism of late Precambrian rocks in central northeastern Nevada and adjacent Utah: Am. Assoc. Petroleum Geol. Bull., v. 46, no. 3, p. 289-343.

Misra, S. B., 1971, Stratigraphy and depositional history of late Precambrian coelenterate-bearing rocks, southeastern Newfoundland: Geol. Soc. America Bull., v. 82, no. 4, p. 979-988.

Moorbath, S., O'Nions, R. K., Pankhurst, R. J., Gale, N. H., and McGregor, V. R., 1972, Further rubidium-strontium age deter- 
minations on the very early Precambrian rocks of the Godthaab district, west Greenland: Nature (Physical Sciences), v. 240, Nov. 27 , p. $78-82$.

Morey, G. B., and Sims, P. K., 1976, Boundary between two Precambrian W terranes in Minnesota and its geologic significance: Geol. Soc. America Bull., v. 87, no. 1, p. 141-152.

Muehlberger, W. R., Denison, R. E., and Lidiak, E. G., 1967, Basement rocks of the continental interior of the United States: Am. Assoc. Petroleum Geologists Bull., v. 51, no. 12, p. 2351-2380.

Muehlberger, W. R., Hedge, C. E., Denison, R. E., and Marvin, R. F., 1966, Geochronology of the Midcontinent Region, United States; part 3, Southern area: Jour. Geophys. Research, v. 71, no. 22, p. $5409-5426$

Nelson, C. A., 1962, Lower Cambrian-Precambrian succession, White-Inyo Mountains, California: Geol. Soc. America Bull., v. 73 , no. 1 , p. $139-144$.

Newhouse, W. H., and Hagner, A. F., 1957, Geologic map of the anorthosite areas, southern part of Laramie Range, Wyoming: U.S. Geol. Survey Mineral Inv. Field Studies Map MF-119. scale $1: 63,360$.

Noble, J. A., and Harder, J. O., 1948, Stratigraphy and metamorphism in a part of the northern Black Hills and the Homestake Mine, South Dakota: Geol. Soc. America Bull., v. 59, no. 9, p. 941-976.

Noble, J. A., Harder, J. P., and Slaughter, A. L., 1949, Structure of part of the northern Black Hills and the Homestake Mine, South Dakota: Geol. Soc. America Bull., v. 60, no. 2, p. 321-352.

Noble, L. F., 1914, The Shinumo quadrangle, Grand Canyon district, Arizona: U.S. Geol. Survey Bull. 549, 100 p.

Obradovich, J. D., and Peterman, Z. E., 1968, Geochronology of the Belt Series, Montana: Can. Jour. Earth Sci., v. 5, no. 3, p. 737747.

Odom, A. L., and Fullagar, P. D., 1973, Geochronologic and tectonic relationships between the inner Piedmont, Brevard zone, and Blue Ridge belts, North Carolina: Am. Jour. Sci., v. 273-A (Cooper volume), p. 133-149.

Odom, A. L., Kisch, S. A., and Leggo, P. J., 1973, Extension of the Grenville basement to the southern extremity of the Appalachians; U/Pb ages of zircons [abs.]: Geol. Soc. America Abstracts with Programs, v. 5, no. 5 (Southeastern Sec., 22d Ann. Mtg.), p. 425 .

Oray, Erogan, Hinze, W. J., and O'Hara, Norbert, 1973, Gravity and magnetic evidence for the eastern termination of the Lake Superior syncline: Geol. Soc. America Bull., v. 84, no. 8, p. 27632780 .

Page, L. R., and others, 1953, Pegmatite investigations, 1942-45, Black Hills, South Dakota: U.S. Geol. Survey Prof. Paper 227, 228 p.

Palmer, A. R., 1967, Cambrian trilobite distributions in North America and their bearing on Cambrian paleogeography in Newfoundland, in Kay, Marshall, ed., North Atlantic geology and continental drift: Am. Assoc. Petroleum Geologists Mem. 12, p. 135-144.

Park, C. F., Jr., and Cannon, R. S., Jr., 1943, Geology and ore deposits of the Metaline quadrangle, Washington: U.S. Geol. Survey Prof. Paper 202, $81 \mathrm{p}$

Pasteels, Paul, and Silver, L. T., 1966, Geochronologic investigations in the crystalline rocks of the Grand Canyon, Arizona [abs.], in Abstracts for 1965: Geol. Soc. America Spec. Paper 87, p. 124.

Peterman, Z. E., and Hedge, C. E., 1968, Chronology of Precambrian events in the Front Range, Colorado: Can. Jour. Earth Sci., v. 5, no. 3 , p. $749-756$

Pettijohn, F. J., 1943, Archean sedimentation: Geol. Soc. America Bull., v. 54, no. 7, p. 925-972.

1972, The Archean of the Canadian Shield, a resume, in Doe, B. R., and Smith, D. K., eds., Studies in mineralogy and Precam- brian geology: Geol. Soc. America Mem. 135, p. 131-149,

Poole, W. H., and others, 1970, Geology of southeastern Canada, in Douglas, R. J. W., ed., Geology and economic minerals of Canada: Canada Geol. Survey Econ. Geology Rept. 1, 5th ed., p. 228-304.

Price, R. A., 1964, The Precambrian Purcell System in the Rocky Mountains of southern Alberta and British Columbia: Canadian Petroleum Geologists Bull., v. 12, Field Conf. Guidebook Issue, p. 399-426.

Quinn, A. W., 1971, Bedrock geology of Rhode Island: U.S. Geol. Survey Bull. 1295, 68 p.

Raaben, M. E., 1969, Columnar stromatolites and later Precambrian stratigraphy: Am. Jour. Sci., v. 267, no. 1, p. 1-18.

Rankama, Kalervo, 1970, Proterozoic, Archean, and other weeds in the Precambrian rock garden: Geol. Soc. Finland Bull. 42, p. 211-222.

Rankin, D. W., 1970, Stratigraphy and structure of Precambrian rocks in northwestern North Carolina, in Fisher, G. W., Pettijohn, F. J., Reed, J. C., Jr., and Weaver, K. N., eds., Studies of Appalachian geology; Central and Southern: Interscience Publishers, New York, p. 227-245.

Rankin, D. W., Espenshade, G. B., and Shaw, K. W., 1973, Stratigraphy and structure of the metamorphic belt in northwestern North Carolina and southwestern Virginia; a study from the Blue Ridge across the Brevard zone to the Sauratown Mountains anticlinorium: Am. Jour. Sci., v. 273-A (Cooper volume), p. 1-40.

Rankin, D. W., Stern, T. W., Reed, J. C., Jr., and Newell, M. F., 1969, Zircon ages of felsic volcanic rocks in the upper Precambrian of the Blue Ridge, Appalachian Mountains: Science, v. 166, Nov. 7, p. $741-744$.

Ratte, J. C., and Wayland, R. G., 1969, Geology of the Hill City quadrangle, South Dakota; a preliminary report: U.S. Geol. Survey Bull. 1271-B, p. B1--B14.

Redden, J. A., 1963, Geology and pegmatites of the Fourmile quadrangle, Black Hills, South Dakota: U.S. Geol. Survey Prof. Paper 297-D, p. 199-291.

1968, Geology of the Berne quadrangle, Black Hills, South Dakota: U.S. Geol. Survey Prof. Paper 297-F, p. 343-408.

Reed, J. C., Jr., 1969, Ancient lavas in Shenandoah National Park area near Luray, Virginia: U.S. Geol. Survey Bull. 1265, 43 p.

Reid, R. R., 1963, Metamorphic rocks of the northern Tobacco Root Mountains, Madison County, Montana: Geol. Soc. America Bull., v. 74 , no. 3 , p. 293-306.

Rezak, Richard, 1957, Stromatolites of the Belt Series in Glacier National Park, Montana: U.S. Geol. Survey Prof. Paper 294-D, p. $127-154$

Rodgers, John, 1972, Latest Precambrian (post-Grenville) rocks of the Appalachian region: Am. Jour. Sci., v. 272, p. 507-520.

Rohrbacher, R. G., 1973, Asbestos in the Allamoore talc district, Hudspeth and Culberson Counties, Texas: Texas Univ. Bur. Econ. Geology Circ. 73-1, 17 p.

Ross, C. P., 1963, The Belt Series in Montana; with a geologic map compiled by Betty A. L. Skipp, and a section on paleontologic criteria by Richard Rezak: U.S. Geol. Survey Prof. Paper 346, $122 \mathrm{p}$.

1970, The Precambrian of the United States of America; northwestern United States-the Belt Series, in Rankama, Kalervo, ed., The Precambrian, v. 4: Interscience Publishers, New York, p. 145-251.

Runner, J. J., 1934, Precambrian geology of the Nemo district, Black Hills, South Dakota: Am. Jour. Sci., 5th ser., v. 28, no. 167, p. $353-372$.

-1943 , Structure and origin of Black Hills granite domes: Jour. Geology, v. 51, no. 7, p. 431-457.

Ruppel, E. T., 1975, Precambrian Y sedimentary rocks in east-central Idaho, in Precambrian and Lower Ordovician rocks in eastcentral Idaho: U.S. Geol. Survey Prof. Paper 889, p. 23. 
Sandrock, G. S., and Penley, H. M., 1974, Geologic map of Pine Mountain series and adjacent areas in the southwest Georgia Piedmont [abs.]: Geol. Soc. America Abs. with Programs, v. 6, no. 4 (Southeastern Sec. 23d Ann. Mtg.), p. 395.

Scholten, Robert, Keenmon, R. A., and Kupsch, W. O., 1955, Geology of the Lima region, southwestern Montana and adjacent Idaho: Geol. Soc. America Bull., v. 66, no. 4, p. 345-404.

Shride, A. F., 1967, Younger Precambrian geology in southern Arizona: U.S. Geol. Survey Prof. Paper 566, 89 p.

Silver, L. T., 1960, Age determinations on Precambrian diabase differentiates in the Sierra Ancha, Gila County, Arizona[abs.]: Geol. Soc. America Bull., v. 71, no. 12, p. 1973-1974.

1963, Isotopic investigations of zircons in Precambrian igneous rocks of the Adirondack Mountains [abs.], in Abstracts for 1962: Geol. Soc. America Spec. Paper 96, p. 150-151.

- 1965, Mazatzal orogeny and tectonic episodicity [abs.], in Abstracts for 1964: Geol. Soc. America Spec. Paper 82, p. 185-186. 1968, A geochronologic investigation of the anorthosite complex, Adirondack Mountains, New York, in Isachsen, Y. W., ed., Origin of anorthosite and related rocks: New York State Mus. and Sci. Service Mem. 18, p. 233-251.

1971, Problems of crystalline rocks in the Transverse Ranges [abs.]: Geol. Soc. America Abstracts with Programs, v. 3, no. 1 (Cordilleran Section 64th Ann. Mtg.), p. 193-194.

Silver, L. T., and Green, J. C., 1963, Zircon ages for middle Keweenawan rocks of the Lake Superior Region [abs.]: Am. Geophys. Union Trans., v. 44, no. 1, p. 107.

1972, Time constants for Keweenawan igneous activity[abs.]: Geol. Soc. America Abstracts with Programs, v. 4, no. 7 (Ann. Mtg. Minneapolis), p. 665-666.

Silver, L. T., McKinney, C. R., Deutsch, S., and Bolinger, J., 1963, Precambrian age determinations in the western San Gabriel Mountains, California: Jour. Geology, v. 71, no. 2, p. 196-214.

Silver, L. T., McKinney, C. R., and Wright, L. A., 1962, Some Precambrian ages in the Panamint Range, Death Valley, California [abs.], in Abstracts for 1961: Geol. Soc. America Spec. Paper 95, p. 55.

Sims, P. K., 1970, Geologic map of Minnesota; bedrock geology: Minnesota Geol. Survey Misc. Map M-14. Scale 1:1,100,000.

Sims, P. K., and Morey, G. B., ed., 1972, Geology of Minnesota; a centennial volume in honor of George M. Schwartz: Minnesota Geol. Survey, 632 p.

Sokolov, B. S., 1973, Vendian of northern Eurasia, in Pitcher, M. G., ed., Arctic geology: Am. Assoc. Petroleum Geol. Mem. 19, p. 204-218.

Stewart, D. B., 1974, Precambrian rocks of Seven Hundred Acre Island and development of cleavage in the Islesboro Formation, in Osberg, P. H., ed., Guidebook for field trips in east-central and north-central Maine: New England Intercollegiate Geol. Conf., 64th Ann. Mtg., p. 86-92.

Stewart, J. H., 1970, Upper Precambrian and Lower Cambrian strata in the southern Great Basin, California and Nevada: U.S. Geol. Survey Prof. Paper 620, 206 p.

Stockwell, C. H., 1961, Structural provinces, orogenies, and time classification of rocks of the Canadian Precambrian Shield, in Lowdon, J. A., compiler, Age determinations by the Geological Survey of Canada, rept. 2, Isotopic ages: Canada Geol. Survey Paper 61-17, p. 108-118.

1964, Fourth report on structural provinces, orogenies, and time classification of rocks of the Canadian Precambrian Shield, in Age determinations and geological studies: Canada Geol. Survey Paper 64-17, pt. 1, p. 1-21.

-1968 , Geochronology of stratified rocks of the Canadian Shield: Canadian Jour. Earth Sci., v. 5, no. 3, p. 693-698.

1972, Revised Precambrian time scale for the Canadian Shield: Canada Geol. Survey Paper 72-52, 4 p.
Taylor, F. C., 1971, A revision of Precambrian structural provinces in northeastern Quebec and northern Labrador: Canadian Jour. Earth Sci., v. 8, no. 5, p. 579-584.

Tilton, G. R., Wetherill, G. W., Davis, G. L., and Bass, M. N., 1960, 1000-million-year-old minerals from the United States and Canada: Jour., Geophys. Research, v. 65, no. 12, p. 4173-4179.

Tilton, G. R., Wetherill, G. W., Davis, G. L., and Hopson,C. A., 1958, Ages of minerals from the Baltimore Gneiss near Baltimore, Maryland: Geol. Soc. America Bull., v. 69, no. 11, p. 1469-1474.

Tweto, Ogden, 1968, Geologic setting and interrelationships of mineral deposits in the mountain province of Colorado and southcentral Wyoming, in Ridge, J. D., ed., Ore deposits of the United States 1933-67 (Graton-Sales Volume): Am. Inst. Mining, Metall., and Petroleum Engineers, v. 1, p. 551-558.

Tweto, Ogden, and Sims, P. K., 1963, Precambrian ancestry of the Colorado mineral belt: Geol. Soc. America Bull., v. 70, no. 8, p. 991-1014.

Van Hise, C. R., 1892, Correlation papers; Archean and Algonkian: U.S. Geol. Survey Bull. 86, 594 p.

Van Hise, C. R., and Leith, C. K., 1909, Precambrian geology of North America: U.S. Geol. Survey Bull. 360, 959 p.

Van Schmus, W. R., 1972, Geochronology of Precambrian rocks in the Penokean foldbelt subprovince of the Canadian Shield [abs.]: 18th Ann. Inst. on Lake Superior Geology, pt. 1, paper 32, Houghton, Mich.

Van Schmus, W. R., Medaris, L. G., Jr., and Banks, P.O., 1975a, Geology and age of the Wolf River bathoiith, Wisconsin: Geol. Soc. America Bull. v. 86, no. 7, p. 907-914.

Van Schmus, W. R., Thurman, E. M., and Peterman, Z. E., 1975 b, Geology and $\mathrm{Rb} / \mathrm{Sr}$ geochronology of middle Precambrian rocks in eastern and central Wisconsin: Geol. Soc. America Bull., v. 86, no. 9 , p. $1255-1265$.

Walcott, C. D., 1889, Study of a line of displacement in the Grand Canyon in northern Arizona: Geol. Soc. America Bull., v. 1, no. 1, p. $49-64$.

1895, Algonkian rocks of the Grand Canyon of the Colorado: Jour. Geology, v. 3, no. 3, p. 312-330.

1899, Precambrian fossiliferous formations: Geol. Soc. America Bull., v. 10, no. 4, p. 199-244.

Walker, J. F., 1926, Geology and mineral deposits of the Windermere map area, British Columbia: Canada Geol. Survey Mem. 148, $69 \mathrm{p}$.

Wallace, C. A., and Crittenden, M. D., Jr., 1969, The stratigraphy, depositional environment, and correlation of the Precambrian Uinta Mountain Group, western Uinta Mountains, Utah, in Lindsay, J. B., ed., Geologic guidebook of the Uinta Mountains, Utah's maverick range: Intermountain Assoc. Geol. 16th Ann. Field Conf., p. 126-141.

Walton, M. S., and de Waard, D., 1963, Orogenic evolution of the Precambrian in the Adirondack highlands; a new synthesis: Koninkl. Nederlands Akad. Weternsch. Proc. B. 66, p. 98-106.

Wasserburg, G. J., Albee, A. L., and Lanphere, M. A., 1964, Migration of radiogenic strontium during metamorphism: Jour. Geophys. Research, v. 69 , no. 20 , p. $4395-4401$.

Wasserburg, G. J., and Lanphere, M. A., 1965, Age determinations in the Precambrian of Arizona and Nevada: Geol. Soc. America Bull., v. 50, no. 7, p. 1113-1164.

Wasserburg, G. J., Wetherill, G. W., Silver, L. T., and Flawn, P. T., 1962, A study of the ages of the Precambrian of Texas: Jour. Geophys. Research, v. 67, no. 10, p. 4021-4047.

Wells, J. D., Sheridan, D. M., and Albee, A. L., 1964, Relationship of Precambrian quartzite-schist sequence along Coal Creek to Idaho Springs Formation, Front Range, Colorado: U.S. Geol. Survey Prof. Paper 454-O, p. O1-O25.

Wheeler, H. E., 1965, Ozark Precambrian-Paleozoic relations: Am. Assoc. Petroleum Geologists Bull., v. 49, no. 10, p. 1647-1665. 
Whelan, J. A., compiler, 1970, Radioactive and isotopic age determinations of Utah rocks: Utah Geol. and Mineralog. Survey Bull. $81,25 \mathrm{p}$.

White, W. S., 1960, The Keweenawan lavas of Lake Superior; an example of flood basalts: Am. Jour. Sci., v. 258A (Bradley vol.), p. 367-374.

-1966, Geologic evidence for crustal structure in the western Lake Superior basin, in Steinhart, J. S., and Smith, T. J., eds., The earth beneath the continents: Am. Geophys. Union Geophys. Mon. 10, p. 28-41.

Wilson, E. D., 1939, Precambrian Mazatzal revolution in central Arizona: Geol. Soc. America Bull., v. 50, no. 7, p. 1113-1164.

Wilson, J. Tuzo, 1969, Aspects of the different mechanics of ocean floors and continents: Tectonophysics, v. 8, no. 4-6, p. 281-289.

Wright, L. A., 1968, Talc deposits of the southern Death ValleyKingston Range region, California: California Div. Mines and
Geology Spec. Rept. 95, 79 p.

Wright, L. A., and Troxel, B. W., 1966, Strata of late PrecambrianCambrian age, Death Valley region, California-Nevada: Am. Assoc. Petroleum Geologists Bull., v. 50, no. 5, p. 846-857.

1967, Limitations of right-lateral strike-slip displacement, Death Valley and Furnace Creek fault zones, California: Geol. Soc. America Bull., v. 78, no. 8, p. 933-950.

Zartman, R. E., 1964, A geochronologic study of the Lone Grove pluton from the Llano uplift, Texas: Jour. Petrology, v. 5, pt. 2, p. 359408 .

1965, Rubidium-strontium age of some metamorphic rocks from the Llano uplift, Texas: Jour. Petrology, v. 6, pt. 1, p. 28-36.

Zartman, R. E., and Stern, T. W., 1967, Isotopic age and geologic relationships of the Little Elk Granite, northern Black Hills, South Dakota, in Geological Survey research 1967: U.S. Geol. Survey Prof. Paper 575-D, p. D157-D163. 